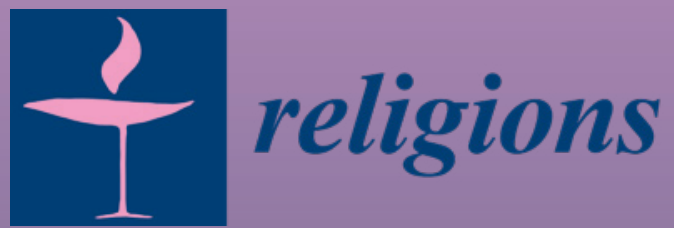

Religion and

International

Relations in the

Middle East

Edited by

Sotiris Roussos

Printed Edition of the Special Issue Published in Religions 
Religion and International Relations in the Middle East 



\section{Religion and International Relations in the Middle East}

Special Issue Editor

Sotiris Roussos 
Special Issue Editor

Sotiris Roussos

Associate Professor,

Department of Political Science

and International Relations,

University of the Peloponnese

Greece

Editorial Office

MDPI

St. Alban-Anlage 66

4052 Basel, Switzerland

This is a reprint of articles from the Special Issue published online in the open access journal Religions (ISSN 2077-1444) in 2020 (available at: https://www.mdpi.com/journal/religions/special_issues/ international_relations).

For citation purposes, cite each article independently as indicated on the article page online and as indicated below:

LastName, A.A.; LastName, B.B.; LastName, C.C. Article Title. Journal Name Year, Article Number, Page Range.

ISBN 978-3-03936-527-2 (Hbk)

ISBN 978-3-03936-528-9 (PDF)

(C) 2020 by the authors. Articles in this book are Open Access and distributed under the Creative Commons Attribution (CC BY) license, which allows users to download, copy and build upon published articles, as long as the author and publisher are properly credited, which ensures maximum dissemination and a wider impact of our publications.

The book as a whole is distributed by MDPI under the terms and conditions of the Creative Commons license CC BY-NC-ND. 


\section{Contents}

About the Special Issue Editor $\ldots \ldots \ldots \ldots \ldots \ldots \ldots \ldots$ vii

\section{Sotiris Roussos}

Introduction-Issues and Debates on Religion and International Relations in the Middle East

Reprinted from: Religions 2020, 11, 263, doi:10.3390/rel11050263 . . . . . . . . . . . . . . 1

\section{Mariano Barbato}

Postsecular Plurality in the Middle East: Expanding the Postsecular Approach to a Power Politics of Becoming

Reprinted from: Religions 2020, 11, 162, doi:10.3390/rel11040162 . . . . . . . . . . . . . 9

\section{Anna M. Solarz}

Religion and International Relations in the Middle East as a Challenge for International Relations (IR) Studies

Reprinted from: Religions 2020, 11, 150, doi:10.3390/rel11030150 _ . . . . . . . . . . . . 2

\section{Marina Eleftheriadou}

Fragmentation and Cooperation in the Jihadi International (Sub)System: 'Islamic State' vs. Al-Qaeda and Beyond

Reprinted from: Religions 2020, 11, 168, doi:10.3390/rel11040168

\section{Ihab Shabana}

Crusaders in Reverse? The Emergence of Political Islam in the Middle East and the Reactions of British Foreign Policy, 1978-1990

Reprinted from: Religions 2020, 11, 196, doi:10.3390/rel11040196 . . . . . . . . . . . . . .

\section{Moria Bar-Maoz}

A Theory on the Involvement of Religion in National Security Policy Formulation and Implementation: The Case of Israel before and after the Religionization of Its Security Environment

Reprinted from: Religions 2020, 11, 227, doi:10.3390/rel11050227 . . . . . . . . . . . . . . .

\section{Panos Kourgiotis}

'Moderate Islam' Made in the United Arab Emirates: Public Diplomacy and the Politics of Containment

Reprinted from: Religions 2020, 11, 43, doi:10.3390/rel11010043 . . . . . . . . . . . . . . . 96

\section{Stella Athanasoulia}

From 'Soft' to 'Hard' to 'Moderate': Islam in the Dilemmas of Post-2011 Saudi Foreign Policy Reprinted from: Religions 2020, 11, 211, doi:10.3390/rel11040211 . . . . . . . . . . . . . . 113 



\section{About the Special Issue Editor}

Sotiris Roussos Associate Professor of International Relations and Religion in the Middle East and the Mediterranean at the Department of Political Science and International Relations of the University of Peloponnese and Scientific Supervisor of the Centre for Mediterranean, Middle East, and Islamic Studies (CEMMIS). From 2015 to 2018, he was Coordinator of the Centre for Religious Pluralism in Middle East (CRPME). He served as Senior Middle East Expert at the Greek Foreign Ministry, and was member of the Task Force for the Palestinian Refugees and Water Issues of the EU Special Representative for the Middle East and of the International Informal Group on the Status of Jerusalem. Sotiris Roussos was, in 2009, appointed Personal Envoy for the Mediterranean Partners of the President-in-Office of the OSCE. He was Visiting Scholar at the University of California, Santa Barbara (UCSB) in 2012. He has written extensively on the Middle-East Christians as well as on religion and regional politics in the Middle East. 

Editorial

\title{
Introduction-Issues and Debates on Religion and International Relations in the Middle East
}

\author{
Sotiris Roussos \\ Department of Political Science and International Relations, University of the Peloponnese, 20132 Corinth, \\ Greece; sroussos67@gmail.com
}

Received: 18 April 2020; Accepted: 19 May 2020; Published: 21 May 2020

\begin{abstract}
By the end of the 20th century, after great political upheavals, two world wars, the decolonization process and political, social and scientific revolutions, it is hard to miss that the world is in a deep de-secularization process. In the Middle East, this process has taken multiple trajectories and has made geopolitics of religion central in reshaping regional issues and in restructuring modes of international politics and international system's intervention in the Middle East.
\end{abstract}

Keywords: religion; international relations; Middle East; Islam; foreign policy regional politics; non-state actors; global order

\section{The Role of Religion in International Politics}

International Relations theories have been based on the argument that the Westphalian Treaty excluded religion from international politics, pushing it outside of the public sphere. Religion belonged, according to this argument, to the sphere of individual and of the irrational, and as such could not be considered in analyzing international politics. Cold War international relations saw in religion a mere ideological tool, despite that the Irish issue, the India-Pakistan conflict and the Iran-Iraq war had an inherent religious element. Political science theories had, for analytical purposes, reduced religions to institutions and handily categorized them as non-government or transnational organizations, mere elements of the civil society acting in accordance with rational choice theory. What stays out of scope in such definitions is the experience of the communion with God, the spiritual life of religious communities (Kubálková 2000, pp. 682-83).

Since the Enlightenment, among political and social thinkers and scientists prevailed the view that religion constitutes a relic system of ideas of pre-modern societies of the past, and that technological progress and the development of modern political institutions would minimize its role in society (Roussos 2015, p. 54). Central in this exclusion of religion from international relations is the theory of secularization in modern societies, understood either as a decline in people's religiosity and/or as a process of withdrawal of religion from the public to the private (Fox 2001, p. 56).

Following the secularization theory, the modernization processes not only would reduce religion to the private sphere, but they also would eliminate religious influence on the society. This approach overlooks, however, several issues that place religion at the center of the public sphere even during periods of modernization. First, the decline of the role of religion was never lineal; instead we observe several moments of religious revival in the midst of rapid modernization. The nineteenth century, an era of intense globalized modernization was also an era of tremendous reach of world religions and of their missionary, educational, publishing and cultural impact (Bayly 2004, p. 325). Pankaj Mishra focuses on two great late 19th century Asian intellectuals, al-Afghani and Liang Qichao, who tried to reconsider their religious tradition in order to bring it in harmony with an onward modern intellectual movement (Mishra 2012).

In the early twentieth century the Irish national movement enlisted the structural rigor and the spiritual influence of the Catholic Church (English 2008). The Algerian anticolonial movement, in the 
interwar period, was based mainly on the dichotomy between French and Muslims (Zack 2002, p. 80). Hindu and American Christian fundamentalisms were formed in the late 1920s.

Secularization theory treats all religions as monolithic, static and uniform. It also refers to a certain episode or episodes and historical periods and not to a wider circle of decline and reassertion of religion. Nationalism has been seen as a secular ideology but in fact it has integrated religion by nationalizing it. Greek, Hindu, Jewish and Irish nationalisms have been largely defined by religion, while Britain and the Netherlands were long considered Protestant nations before including the Catholics in the nation-state (van der Veer 2015, pp. 9-10). Two centuries after the Westphalian Treaty, religion had re-asserted its role in the public sphere, impacting considerably on the global order. In the early 19th century, religious leaders played a decisive role in the abolition of slavery in the British Empire and the Second and Third Great Religious Awakenings influenced modern American social culture and activism. Ibn Taimiyya, a 13th century Muslim thinker, influenced Islamist movements in the 20th century.

At the end of the 19th century, after two industrial revolutions and the most expansive globalization in human history, the world experienced a re-emergence of "world religions" at a pace unthinkable until then. Likewise, by the end of the 20th century, after great political upheavals, two world wars, the decolonization process and all the political, social and most importantly scientific revolutions, it is hard to miss that the de-secularization process has taken multiple trajectories and has made geopolitics of religion central in reshaping regional issues and in restructuring modes of international politics and international system's intervention particularly in the Middle East.

Religion influences international politics through decision-makers in various states as well as through the power of the voters who have strong religious affiliation. The evangelical communities influence on American foreign policy in the era of Reagan, Bush Jr. and Trump are cases in point. Religion is also a source of legitimation of authority and of support or opposition to certain state policies at national and international levels. By the end of the 20th century, more and more religious conflicts were becoming international issues (Fox 2001, p. 59) such as the Sunni-Shia divide in the Middle East, the conflict in Caucasus and the ascent of Jihadism in West Africa.

Furthermore, the tendency of secular policymakers to disregard the role of religion and religious institutions in contemporary affairs hinders our ability to respond to current challenges in international politics. Contrary to the notion that religion and religious grievances are fueling conflicts, religious actors have contributed most effectively in conflict resolution (Schewel 2014, pp. 57-58). Religion can be influential in shaping leadership style and re-directing leadership attention. It can also frame the socio-cultural context in which foreign policy is conducted. Such socio-cultural context may set the criteria of who is the enemy of the state or the enemy of the religion and the faithful, and it affects the role of the self and the other in regional politics (Warner and Walker 2010).

According to Elizabeth Hurd Shakman, religion cannot be neglected in the study of international politics for three main reasons. First, the United States and the rest of the Western world failed in imposing their model of secular democracy on the rest of the world. Second, superpower's foreign policy under Bush Jr., though nominally secular, was largely influenced by religious communities and ideologies. Third, there is a significant increase of religious movements and organizations of transnational character and international activism and outreach (Hurd Shakman 2008, p. 134).

The resurgence of religion in international politics is closely related to the crisis of modernity and the failure of the secular state to advance democracy and development in the less developed world. Scott M. Thomas argued that this religious resurgence is connected to a search for authentic identity and just development in the non-western world, and in this way it can be seen as a revolution against the West (Thomas 2000, pp. 816-17).

In the case of identity groups (nations), it is smaller groups that determine the threats to identity groups' right of survival, and they reserve the right to speak and act on its behalf (Wæver 1996, pp. 107-9). In states where religious and national identity are tightly intertwined, religion can play a decisive role in determining security threats and generating collective fear. Religious groups 
can thus be more influential than political ones, claiming that they speak and act on behalf of the nation. They religionize foreign and security policy by setting security threats in a sacred context (Juergensmeyer 2001, p. 468).

Religious activism can take a violent turn. Theories of social movements, fundamentalism and apocalyptic warriors can, according to Gregg, explain the circumstances under which religious activism uses violent means. Religion may mobilize pre-existing groups, networks and resources forming social movements in new moral frameworks, where their members can find common meaning and purpose. Grassroots networks and alliances are united by their shared view of "just order" found on submission to God's sovereignty. With their political opportunities blocked or their aspirations frustrated these movements can resort to violence. According to fundamentalism theory, various religious groups are fighting to bring the societies back to the straight path of the true faith. They may choose violence when they perceive political authority or current international order as the main promoter of secularism and moral decay. Last, apocalyptic groups aim at violently "intervening" in human history bringing closer the End of the Days (Gregg 2016).

\section{Alternative Perspectives in Global Governance}

After the collapse of the bi-polar world in the 1990s, there was a tendency to a post-democratic era and the transformation of what we knew as liberal democracy. The ideological basis of this tendency is that all individuals in the planet possess human rights. Transnational frameworks, norms, international institutions and international NGOs, claiming to represent a global civil society, are anchoring on the human rights basis, questioning representative majority-rule democracy and the nation-state's credibility, sometimes reducing its sovereignty. Around this project of a global civil society, a new transnational elite has been built with "corporate" interests in its success.

At the same time, we experience the ascent of another tendency within mainly Muslim societies and Muslim communities in the West, which seeks a new post-democratic world based not on human rights but on "just order". This "just order" is not founded on ideological, egalitarian, class-structured premises but on absolute submission to God's sovereignty, transcending and sometimes questioning the nation-state's sovereignty or any other human-built structure. Around this project huge networks of violent and non-violent disposition have been built with millions of members, who also pursue an alternative global governance scheme, the global Ummah.

"Just order" in Islam means the merger of faith and law in the individual's life. According to Abdulaziz Sachedina, a rather modernist Muslim thinker, such a merger creates a sense of security and integrity in the individual and in the collective life of the community and leads to social harmony (Sachedina 2006, p. 8). The separation between law and faith results in chaos, confusion and violence and thus destroys the community of the faithful. Ultimately, submission to an all-encompassing God is the only condition for the creation and maintenance of justice in the society and equity on earth. Particularly for political Islam (Islamists), there is no other sovereignty than God's, and there is no differentiation between the public sphere and the individual. Islam is a religion first and foremost of the public realm.

What is more, contrary to the western liberal paradigm, Muslim just order reasons about political matters in religious terms, debating whether the Qur'an allows loyalty to the state, support for democratic institutions, political participation, equal rights for women or participation in a particular war. In these and other ways Islamists introduce a theological form of political reasoning in which others cannot participate but by whose outcome they are deeply affected. Some of them even consider democracy as a sort of polytheism since sovereignty rests on people and not on a unitary and all-encompassing God. This does not mean that the Islamists do not participate in electoral procedures and other functions of liberal democracies, but they are doing so on a contractual manner, or by using norms and institutions for promoting the Muslim community and faith.

For various reasons, and out of multiple developments, such views have a growing impact in Muslim communities. These now exceed 1.8 billion individuals, they have high birth rates and they 
are the majority in 55 states, one of them a nuclear power, with more than $60 \%$ of the planet's energy resources (SESRIC 2012) and, for the first time in history, large communities in non-Muslim states, particularly in Europe (Lipka and Hackett 2017).

As has been noted by Bikhu Parekh, "international events played an important part in reinforcing the consciousness of Islamic identity". The Iranian revolution, the Afghan Mujahidin resistance to Soviet occupation and the Muslim struggle against injustices and oppression in different parts of the world gave Muslims common global causes and sharpened the awareness of the Ummah or the global Muslim community. The growing influence of religious institutions generously funded by the oil-rich Muslim countries, especially Saudi Arabia, reinforced this trend (Parekh 2008, pp. 8-9).

The Islamic Ummah can be seen as a macro level ideological structure, with geopolitical, institutional underpinnings and political structures comparable to the ideological structure of global liberalism, which today dominates notions of global governance (Adamson 2005, p. 548). In the field of finance and economy, there is a fast-growing development of an Islamic model, in compliance with Shari'a law entrepreneurship. Islamic financial and banking activities reached an impressive size of around USD 2 trillion in 2014 (The Economist 2014). During the last few years, expansion of Islamic financial instruments has also embraced a huge variety of modalities. The Islamic social finance offers an alternative view on finance which includes Zakat (almsgiving), Waqf (endowments), Sadaqah (charity) as well as Qardh al-hasan (interest-free loans) and focuses on socially beneficial activities. The total amount of Islamic social finance exceeded, in 2018, the USD 2.5 trillion assets of the commercial Islamic finance sector, with Zakat alone reaching USD 1 trillion per year (Rehman 2019).

A wide network of satellite TV and internet sites have been mushrooming, creating a sort of imagined Ummah, in a way parallel to that of publishing in the formation of modern European identities. Moreover, there is a growing number of varying organisations that promote the Islamic faith and Islamic way of living. Some analysts tend to admit that the Islamic organisations, be it political, educational, violent or non-violent, have used the internet and the information age more efficiently than the political structures of global liberalism. Muslim youth in Britain and Muslim girls in France led the battle for Islam, quite often against the wishes of their parents, and demanded that the state should recognize, respect and make public space for it. By the late 1980s, Islam became a powerful political presence in Europe, its power deriving from its number, militancy, firm sense of identity, and global connections. Moreover, organisations of mixed political, social and preaching purposes are dominating Muslim communities and societies, and recruit thousands of members. Hizb-ut-Tahrir, perhaps the most globalised of them, is currently active in over forty countries. One of its main websites has seven languages listed: Arabic, Turkish, Russian, English, German, Urdu and Danish.

Features of Islamic Ummah can connect the local with the global, questioning at the same time the Western definitions for the state. Saudi authors of jihadist texts adopted the idea that the first state of Saudi Arabia in the late 18th century was "a political entity unbounded by defined territorial boundaries, unrecognized by the international community, and uncontaminated by international treaties and legal obligations. The first state is a local political configuration that defied regional and international contexts and promised to make true Islam hegemonic. They regard this state as a revival of the state of prophecy where the community was subject to divine law. Membership was determined not by recognized frontiers but by submission to the rightful Imam, whose authority over distant territory was recognized by paying zakat, receiving his judges, and performing jihad under his banner" (Al-Raseed 2008). Hence, since the present Saudi state cannot represent the model, as according to the same narrative it is corrupted and dependent on infidel powers, then the true Islamic identity should be sought not in local concepts but in global ones, in a reterritorialized utopia, which is again unbound by external constraints, the global Muslim Ummah.

\section{The Challenges to the Global and Regional Order}

In the dawn of the third decade of the 21st century, there are three challenges that transform the global order and regional politics in the Middle East. First, there is a serious challenge to the 
nation-state. The formation of nation-states in the Middle East was based on the uprooting of local cognitive traditions and the imposition of western secular "rational" norms and bureaucratic frameworks. They exerted high pressure on religion in order to move it to the private sphere and placed religious institutions under strict state control. National liberation movements tried to reconstruct religious traditions in order to fit to their secular ideology instead of enriching their ideological repertoire with these traditions. The failure of these states to establish a credible social contract, their rampant corruption, cruel coercive mechanisms and inability to solve chronic socio-economic problems and their failure, particularly in Syria and Iraq, to unite different ethnoreligious groups under the banner of a cohesive national project led to a complete de-legitimization of the secular nation-state and its "rational" underpinnings. As a result, various Islamic movements and hybrid political entities tried to resist against or substitute for the failed secular model.

The conflicts of Syria, Iraq, Yemen and Libya led to the fragmentation of these countries to alternate layers of hybrid politico-military entities which connect to each other by religious, ethnic/tribal or local bonds. The challenge in these cases is much more intense, more so since Syria and Iraq belonged to the core of the Arab order and were characterized by an almighty and ideologically consolidated domestic sovereignty. Even Egypt faced a threatening jihadist insurgency in the Sinai, something rather unimaginable for the strong Egyptian state two decades ago.

Second, there is a challenge to global order. We are in the midst of widespread "disruption" or incoherence of what we know as global order. Hardt and Negri have argued that the "planetary networks of social production and reproduction and the constitution of global governance are increasingly out of sync." (Hardt and Negri 2019, pp. 68-69). Regional powers are not ready to acquiesce to the hegemonic role of the superpower in their region. Powers such as China, Russia, India, Iran, and Turkey act with a large degree of autonomy, without, however, challenging the superpower's preponderance in the global scale.

There was a sharp increase of the occurrences of civil war in the last two decades, reaching fifty-two instances in 2015, the highest number of civil conflicts in the modern era. These conflicts have a high degree of internationalization as they are transformed into regional conflicts with the participation of regional and global powers. At the same time these conflicts are not waged in delimited areas as it was the case with national liberation movements, but they are scattered in many areas beyond certain borders (Fearon 2004). In such fragmented international and regional environments politico-military, non-state actors have become the third challenge to global and regional order. State-like actors like the Kurdish entities in Iraq and Syria and Hamas in Gaza, states-within-states like Hezbollah and hybrid states such as the "Islamic State" have been shaping regional order in the last decade. Particularly religious politico-military non state actors have worked as mechanisms of inclusion into a privileged collective self and of the exclusion of "others".

The ascent of the "Islamic State" and its consolidation through hybrid state structures for a considerable period of time has been the most serious challenge to the Middle East nation-state. It is the first time that a state was set up by a multiethnic body politic without a dominant ethnic group. The "Islamic State" fostered a neo-medieval global order regarding borders and divine sovereignty and it transcended nation-state's constants, appropriating at the same time functions of the secular state (Eleftheriadou and Roussos 2018). The "Islamic State" was fast to outline what it has to offer to its "citizens", reminiscing and echoing previous social contracts (employment, welfare and health services) between the regimes and their citizens in the 20th century. These benefits and services provided an attractive alternative to the Sunni communities under "Islamic State's" control, especially in Iraq, given their marginalization and absence from the political and military scene as well as unemployment. The insecure Sunni communities that demonstrate a regression in human development had not any choice to opt out of its "benefits and services".

After the eruption of civil strife in Syria and Iraq, widespread violence and harassment, mainly by jihadist groups, came to substantiate fears for extinction of the Christians and other minorities in the region (CRPME 2016). Various jihadist groups have perpetrated ongoing ethnic cleansing. 
Regional antagonism in both Syria and Iraq has further exacerbated the conflicts, ignoring the dangers for non-Muslim communities. The churches' leadership initially tried to balance between its past co-optation policy with the regime and the growing instability and insecurity on the ground, more so since their faithful is territorially dispersed and the control on the ground is shifting. Middle Eastern churches are becoming increasingly diasporic instead of regional. Large numbers of Middle Eastern migrants and exiles in the Americas, Europe and Australia have been the basis of flourishing Eastern churches' parishes and bishoprics overseas. This means that Middle Eastern Christianity is linked to a world religious tradition.

Regional and global upheavals brought serious changes in the survival strategies of the Christian communities in the Middle East. First, Christians in the Middle East, particularly in Syria and Iraq, are facing a great danger of extinction resembling the genocides and mass exodus of Christians in the region during the First World War, and are bound to radically re-consider their survival strategies. Second, this might be the time the state in both Syria and Iraq is to rebuild in a federal and decentralized form. Third, the role and position of minorities, of the Christians in particular, in this state-rebuilding process would be the real test on what direction this process would take: towards a more decentralized and open to the world state, or towards autocratic federal states, where strong ethno-religious communities would reign over smaller groups. These questions will certainly be at the center of the debates for the future Middle East in the coming decade and attract the interest of global church actors, the Catholic and the Russian Orthodox Church.

\section{Studying Religion and International Relations in the Middle East}

This Special Issue falls into the fields of "Area Studies" and of "Religion and Politics". As A. Acharya and B. Buzan pointed out "Area Studies should be a main location for sub-systemic theorizing", that is, to produce new knowledge (Acharya and Buzan 2007, p. 291). Today's Area Studies should produce patterns of theorization that consider non-Western International Relations perspectives (Katzenstein 2001, pp. 789-91).

The chapters are divided into three parts. The first includes two articles that deal with the contribution of religion to a post-Western turn in international relations in the Middle East and beyond. Mariano Barbato argues that an expansion of the post secular approach to a power politics of becoming would allow to grasp important trends that strive to integrate the plurality of the region beyond the exclusivist closures of secularist Pan-Arabism or religious Political Islam. The article discusses the post secular conceptual framework of Jürgen Habermas and William Connolly in order to expand their approaches to the analysis of the Middle East. Anna Solarz addresses the search for religion's "suitable place" within IR, taking as a starting point the social changes in the world and the postulated "Mesopotamian turn" in IR. She suggests that, through comparison and contrast with life in societies of the Middle East as it is in practice, religion has been incorporated quite naturally into IR, undermining, at the same time, the "Westphalian presumption".

The second part focuses on the role of state-like non-state actors (ISIS). Marina Eleftheriadou explores the implications of 'Islamic State's' (IS) rise on the international order and the salafi-jihadi movement. She argues that, in its capacity as a de facto revolutionary state, IS challenged the international order because, contrary to revolutionary states in the past, it negates the foundations of the Westphalian system. At the same time, the rise of IS had a tremendous impact on the jihadi (sub)system, as it initiated a period of fragmentation and alliance-building.

The third part focuses on the impact of religion on foreign and security policy (Israel, UAE, UK, Saudi Arabia). Panos Kourgiotis studies the ideological use of religion in the international relations of the United Arab Emirates during the Arab Spring and beyond. His essay examines the politics of 'moderate Islam' and argues that even though 'moderate Islam' has been devised for creating 'soft power', it serves 'sharp power' as well. Moria Bar-Maoz explores how religion has been shaping each of the stages of the decision-making process in which Israeli decision makers have been formulating national security policies since the beginning of the 21st century, focusing on two security issues: 
terrorism and nuclear weapons. The paper argues that the stage in which decision makers identify and assess a threat to national interest has been greatly influenced by Israeli policymakers' operational perceptions on the relations between religion and security. Ihab Shabana studies Britain's encounter with the rise of political Islam in the Middle East and North Africa region and the way(s) that this phenomenon was (were) deciphered. He argues that British officials adopted four analytical schemas that concentrated on the rise of sectarian politics in MENA, the gradual accommodation of non-state actors and organizations in the political analysis, the prospect of an alliance between Islamist and communist forces and last, the prevalence of the idea of Islamic solidarity and Islamic exceptionalism in exerting international politics. Stella Athanassoulia explores the position that religion holds in the Saudi perceptions of stability in the post-2011 era, where safeguarding the status quo remained the priority, while the new administration responded to pressure by shifting towards a 'hard power' foreign policy with questionable results. At a second stage, the paper explores the links between foreign policy choices and internal challenges, namely the promotion of a new, modern image for the kingdom where the notion of 'moderate Islam' has been instrumentalized in order to support the 'Vision 2030' reform program.

This Special Issue explores the contribution of religion in reshaping modernity's contour of International Relations theories in the Middle East and beyond. Hence, it has a twofold purpose: first, to question main presuppositions and perceptions regarding religion and international politics in the Middle East and, second, to reflect on the role(s) of religion in the regional order.

Funding: This research received no external funding.

Conflicts of Interest: The author declares no conflict of interest.

\section{References}

Acharya, Amitav, and Barry Buzan. 2007. Why Is There No Non-Western International Relations Theory? An Introduction. International Relations of the Asia-Pacific 7: 287-312. [CrossRef]

Adamson, Fiona B. 2005. Global Liberalism versus Political Islam: Competing Ideological Frameworks in International Politics. International Studies Review 7: 547-69. [CrossRef]

Al-Raseed, Madawi. 2008. The Local \& the Global in Saudi Salafism. ISIM Review 21: 8-9.

Bayly, Christopher Alan. 2004. The Birth of the Modern World, 1780-1914: Global Connections and Comparisons. Hoboken: Blackwell Publishing.

CRPME. 2016. Untying the Knots of Religious Diversity in Iraqi Kurdistan: Deploying Pluralism against Barbarism. Special Report 2. Available online: http://www.cemmis.edu.gr/index.php/publications/crpmereports/item/609-crpme-special-report-no-2-untying-the-knots-of-religious-diversity-in-iraqi-kurdistandeploying-pluralism-against-barbarism (accessed on 5 March 2020).

Eleftheriadou, Marina, and Sotiris Roussos. 2018. Islamic State's notion of 'mobile' Sovereignty/Territoriality in a Postsecular Perspective. In Islam in International Affairs: Politics and Paradigms. Edited by Nassef Manabilang Adiong, Raffaele Mauriello and Deina Abdelkader. Oxford: Routledge.

English, Richard. 2008. Irish Freedom: The History of Nationalism in Ireland. London: Pan Books.

Fearon, James D. 2004. Why Do Some Civil Wars Last So Much Longer than others. Journal of Peace Research 41: 275-301. [CrossRef]

Fox, Jonathan. 2001. Religion as an Overlooked Element of International Relations. International Studies Review 3: 53-73. [CrossRef]

Gregg, Heather Selma. 2016. Three Theories of Religious Activism and Violence: Social Movements, Fundamentalists, and Apocalyptic Warriors. Terrorism and Political Violence 28: 338-60. [CrossRef]

Hardt, Michael, and Antonio Negri. 2019. Empire Thirty Years On. New Left Review 120: 67-92.

Juergensmeyer, Mark. 2001. The Global Rise of Religious Nationalism. In Religions/Globalizations: Theories and Cases. Edited by Hopkins N. Dwight, Lorentzen Anne Lois, Mendieta Eduardo and Batstone David. Durham: Duke University Press.

Katzenstein, Peter J. 2001. Area and Regional Studies in the United States. PS: Political Science and Politics 34: 789-91. [CrossRef] 
Kubálková, Vendulka. 2000. Towards an International Political Theology. Millennium 29: 675-704. [CrossRef]

Lipka, Michael, and Conrad Hackett. 2017. Why Muslims Are the World's Fastest-Growing Religious Group. Washington: Pew Research Center, Available online: https://www.pewresearch.org/fact-tank/2017/04/06/ why-muslims-are-the-worlds-fastest-growing-religious-group/ (accessed on 5 March 2020).

Mishra, Pankaj. 2012. From the Ruins of Empire: The Revolt Against the West and the Remaking of Asia. London: Allen Lane.

Parekh, Bhikhu. 2008. European Liberalism and 'the Muslim Question'. ISIM Paper 9. Leiden: Amsterdam University Press.

Rehman, Aamir A. 2019. Islamic Finance for Social Good: Sustainable Development in Islamic Social Finance. United Nations Development Program, January 23. Available online: https://www.undp.org/content/undp/ en/home/blog/2019/IFN_ANNUAL_GUIDE_2019_Islamic_Social_Finance.html (accessed on 5 March 2020).

Roussos, Sotiris. 2015. Christianity in the Middle East: Terms for an interdisciplinary debate. Middle East Bulletin 28: $54-56$.

Sachedina, Abdulaziz. 2006. The Role of Islam in the Public Square: Guidance or Governance. ISIM Paper 5. Leiden: Amsterdam University Press.

Schewel, Benjamin. 2014. What Is "Postsecular" About Global Political Discourse? The Review of Faith E International Affairs 12: 49-61.

SESRIC. 2012. Current Stance of Energy Resources and Potential in OIC Member Countries. OIC Outlook Series. Available online: http://www.sesric.org/files/article/459.pdf (accessed on 5 March 2020).

Hurd Shakman, Elizabeth. 2008. The Politics of Secularism in International Relations. Princeton, NJ: Princeton University Press.

The Economist. 2014. Big Interest, No Interest: The Market for Islamic Financial Products is Growing Fast. September 13. Available online: https://www.economist.com/finance-and-economics/2014/09/13/big-interestno-interest (accessed on 5 March 2020).

Thomas, Scott M. 2000. Taking Religious and Cultural Pluralism Seriously: The Global Resurgence of Religion and the Transformation of International Society. Millennium 29: 815-41. [CrossRef]

van der Veer, Peter. 2015. Nation, Politics, Religion. Journal of Religious and Political Practice 1: 7-21. [CrossRef]

Warner, Carolyn, and Stephen Walker. 2010. Thinking About the Role of Religion in Foreign Policy: A Framework for Analysis. Foreign Policy Analysis 7: 113-35. [CrossRef]

Wæver, Ole. 1996. European Security Identities. Journal of Common Market Studies 34: 103-32.

Zack, Lizabeth. 2002. Who Fought the Algerian War? Political Identity and Conflict in French-Ruled Algeria. International Journal of Politics, Culture, and Society 16: 55-97. [CrossRef]

(C) 2020 by the author. Licensee MDPI, Basel, Switzerland. This article is an open access article distributed under the terms and conditions of the Creative Commons Attribution (CC BY) license (http://creativecommons.org/licenses/by/4.0/). 
Article

\title{
Postsecular Plurality in the Middle East: Expanding the Postsecular Approach to a Power Politics of Becoming
}

\author{
Mariano Barbato \\ Center for Religion and Modernity, 48149 Münster, Germany; barbato@uni-muenster.de \\ Received: 4 March 2020; Accepted: 28 March 2020; Published: 1 April 2020
}

\begin{abstract}
Embedded in a critically adapted version of Jürgen Habermas' postsecular approach, this article analyzes empirically and evaluates normatively the role of religion in the Middle East. Integrating and adapting William Connolly's understanding of political change as power politics of becoming, the argument is that an authoritarian pluralism is evolving that, in contrast to secular nationalism and Political Islam, can be called postsecular insofar as it attempts to integrate more strata of the population into the public discourse, regardless of their religious creed but based on interreligious plurality. The Document on Human Fraternity, signed 2019 in Abu Dhabi, is a prime example of that postsecular trend embedded in power politics. The article concludes that the turmoil of the Arab Spring did not pave the way for democracy but for authoritarian and partisan versions of a postsecular public that try to accommodate the plurality of the Middle East.
\end{abstract}

Keywords: postsecular society; Middle East; politics of becoming; desecularization; Jürgen Habermas; William Connolly; Arab Spring; Document on Human Fraternity; Muslim Council of Elders; Pope Francis

\section{Introduction}

The claim that the Middle East could be described as postsecular seems to be counterintuitive. An alleged lack of secularization, a number of deadly conflicts concerning religion, and authoritarian restrictions on public discourse seem to foreclose any meaningful application of the concept to the region. My claim is that an authoritarian version of interreligious pluralism became the postsecular alternative to pan-Arabic secularism and Political Islam-Islamism and Post-Islamism.

The postsecular approach is understood as an analytical tool to observe but also as a normative framework to evaluate an expanding integration of diverse social and religious strata into the public discourse without providing a comprehensive, homogenizing doctrine. Based on these analytical and normative considerations, the Middle East can be called postsecular, if all kinds of religious and non-religious citizens can participate equally in public and politics, as long as they do not intend to reshape society and state on the basis of a homogenizing political creed of their faith. While this normative benchmark cannot be detected in a full sense, an authoritarian move in that direction can be observed in countries such as Egypt or the UAE, organized and connected by transnational elites. The most impressive step within this authoritarian postsecularism was achieved in Abu Dhabi in 2019 when the Document on Human Fraternity (Francis and al-Tayyib 2019) was signed by Pope Francis and Grand Imam Ahmad al-Tayeb. This article's second part will elaborate on these examples to show how the expansion of the postsecular approach to authoritarian power politics of becoming could help us to understand the Middle East.

The argument is embedded in the broad and ongoing critical debate on secularism and secularization theory that has been pioneered, among others, by such diverse thinkers as Talal Assad (Asad 2003), Jose Casanova (Casanova 1994), Charles Taylor (Taylor 2007), or Peter Berger (Berger 1999), who 
allowed, broadly speaking, in their critical examination of the historical development of secularism and secularization theory, a fresh look on alternative frameworks, global trends of desecularization, and the vitality of religion in public.

Methodologically, this article draws on two thinkers within these debates: Jürgen Habermas (Habermas 2006, 2008) and William Connolly (Connolly 1999). Jürgen Habermas has introduced a sophisticated and widely discussed concept of a postsecular society that frames the theoretical background of this study. As it informs, in an adapted version, the basic ideas of my argument, a short reminder of Habermas' concept and its critical discussion opens up the discussion of the first part. This opening serves also as a starting point for a historical analysis that draws attention to the emergence of a public sphere through transnational religious intellectuals within the power politics of authoritarian rulers.

On this crucial point, William Connolly's term "politics of becoming" (Connolly 1999, p. 51) will support my argument based on a critical reading of Habermas. As will be elaborated, Connolly has a normative idea of change and transformation, which he calls "politics of becoming" and which includes a vision of society of deep differences that can nevertheless develop strong social fabrics. However, Connolly is well aware that such a transformation does not often go smoothly and rarely manages to integrate the consensual participation of everyone. Expanding this concept, one could speak about power politics of becoming.

\section{Deep Postsecularism and the Politics of Becoming}

Jürgen Habermas began to speak about a postsecular society only weeks after 9/11 (Habermas 2006, pp. 101-15). Instead of nourishing the secular-religious divide by lumping all kinds of believers together, the philosopher and social scientist presented another option: dividing self-reflexive postsecularists, religious, and agnostics from ideologists who insist on their religious or secularist world views. One of the most important encounters in which he discussed this approach was the debate with Joseph Cardinal Ratzinger, who became shortly afterwards Pope Benedict XVI (Habermas et al. 2006). Habermas discussed and developed his approach in various contexts and debates over a period of almost two decades (Butler et al. 2011; Calhoun et al. 2013; Habermas 2008, 2010). William Connolly conceptualized his postsecular approach of deep pluralism and politics of becoming before Habermas (Barbato and Kratochwil 2009; Connolly 1999; Kaltsas 2019). Here is not the place to elaborate the whole debate, but a recall of the basic components and a brief look on the latest developments seem to be in order to discuss the adaption to the situation in the Middle East.

\subsection{Habermas' Postsecular Approach: Basic Ideas and Current Developments}

Basically, Habermas' argument is threefold. The first point is a sociological analysis: at least for the time being, secularization theory is wrong. There are many modern, well-educated people who still believe in God and accept various kinds of sophisticated, religiously informed doctrines. Note that Habermas still trusts analysts who give evidence that secularization theory might prevail in the long run. However, he also acknowledges that religious people are more resistant in upholding moral arguing under the pressure of a capitalist modernity, which causes social pathologies elsewhere. The second issue is a problem of political theory: given the, at least current, stable existence of religious strata and their moral convictions, a ban of religious arguments from the public sphere is not viable within an inclusivist liberal concept of the public, which is in dire need of support against social pathologies. Rigid secularism as a political project is therefore morally and politically wrong. However, this verdict against secularism is a limited one. Habermas still believes that religious language is less rational than secular language. Rational arguments are the corner stone of every public deliberation, and only they lead to legitimate politically binding and juridically enforceable decisions. Thus, religious claims can be made in public, but as soon as the deliberation process enters political or juridical institutions, which are entitled to make binding and enforceable decisions, religious vernaculars have to be translated into a secular language. The third insight is a philosophical claim: religious language is richer than secular 
discourse. The translation process, which is necessary for a political decision, is also an enrichment for the debate. Secular reasoning freed thoughts from their religious shelf. Sometimes this process destroyed semantics worth being kept or did not succeed in translating all of the valuable meaning that was contained by the religious concept (Barbato and Kratochwil 2009; Calhoun et al. 2013; Habermas 2006; Habermas et al. 2006, pp. 101-15).

Within the debates and developments of Habermas' approach, a few aspects need to be discussed in some more detail with respect to the question of applying the concept to the Middle East: even in his latest work, Habermas trusted Pippa Norris' and Ronald Inglehart's (Norris and Inglehart 2011) empirically ill-proven claim that better-off societies secularize, while poorer and more fertile strata of the world population are more religious (Habermas 2019, p. 84). Progress, according to this view, might thus back secularization theory in the long run. That claim stands historically in stark contrast to the experience of European modernity, in which mass deprivation led to atheist labor movements and the poor peasants of Russia backing Lenin's revolution (Chadwick 1990). Looking at the modern Middle East of the 21st century, in particular at the Arab peninsula with a domestic product far beyond global average, the thesis should be considered false. The so-called oil sheiks are not only fabulously rich, they are able to compete in setting standards in architecture, infrastructure, technology, and sustainability. Nevertheless, there are no indications that these modernization processes will have an impact on religiosity, as would be expected by secularization theory. While there is stiff competition among the various interpretations of Islam, with Qatar on the side of the Muslim Brotherhood and the UAE on the side of authoritarian pluralism, secularist tendencies do not rank high within these societies. Incoming poor migrant labor and the well-off nationals of the Gulf emirates are obviously divided by class, often in their creed, but less in their degree of religiosity. We do not see any history repeating of Marxist working class or Enlightenment bourgeois secularization as demonstrated in early modern Europe. The thesis of rich and secular vs. poor and religious should be considered false due to the example of the Middle East.

Habermas restricts his notion of a postsecular society to Western countries (Habermas 2008). For him, only those societies went through a full modernization process that experienced a balanced combination of religious decline and enlightened religious resistance as a precondition for the postsecular arrangement between secular and religious citizens. Here is not the place to make a global comparison, but it is safe to say that two hundred years of secularization that started initially with Napoleon's Egyptian campaign (1798-1801) and became a genuine Turkish and Arabic project after the end of the Ottoman Empire had some effects in the Middle East. Processes of secularization can be effective in political, public, and private realms. The decline of religion does not have to be sharp or close to zero to observe reversing trends to secularization, which Peter Berger labeled as desecularization (Berger 1999). It is of course open to debate whether secularization will triumph in the long run in the Middle East. It is also possible that religious resistance, beginning with the assignation of French General Kléber by Suleiman al-Halabi (1800), will prevail either because Islam is, for good or bad, immune to full-fledge secularization processes or because Political Islam has better answers to the challenges of modernization. In any case, the Middle East is not just a landscape or a geopolitical region but a public space in which transnational elites and masses discuss their joined and differentiating experiences and judgements as they go through processes of secularization and desecularization.

A brief look at the history of the Middle East might be in order to sketch that development. The pan-Arabism of Gamal Abdel Nasser's Egypt or the Ba'ath Party in Syria and Iraq, the White Revolution of Sha Reza Pachlevi in Iran, the postcolonial socialism of the Algerian Front de Liberation Nationale, the republican and socialist states of Yemen, and Kemal Atatürk's laicism, as well as the Israeli-Palestinian conflict between Zionists and the PLO (Palestine Liberation Organization) were secular enough to classify the Iranian Revolution, the rise of the Muslim Brotherhood, the emergence of the Islamic State, the electoral victory of Recep Tayyip Erdoğan in Turkey and the following settlement of his rule, the Pyrrhus victory of the Islamic Salvation Front and the following Civil War in Algeria, the mainly Shia-Sunni split in Yemen's current war, and the increasing role of religious nationalism 
in the State of Israel and in Hamas' rule in Gaza as clear indicators of desecularization. The rise of Political Islam, broadly understood as a comprehensive political doctrine based on Islam, after the failures of secular nationalism varies but is evident (Cesari 2014; Tamimi and Esposito 2000).

Political Islam challenged not only secularist nationalists but also more traditional monarchies, such as Morocco, Jordan, Saudi-Arabia, and the Gulf Emirates. Those dynasties that were stable enough to survive the secularist and nationalist challenge were able to modernize without compromising their monarchical rule. The demands of democratic participation pressured monarchies with populous nations, such as Morocco or Jordan, to integrate Political Islam within their political system (Brown and Hamzawy 2010). Since the Grand Mosque Seizure of 1979, the Saudi dynasty had to prove the legitimacy of their rule to Wahhabi scholars and fostered Salafism in the region and globally. The home-grown terrorism of Osama Bin Laden worsened the situation (Hegghammer 2010). The Gulf Emirates, such as the UAE or Qatar, whose population is composed mainly of migrant workers, had less internal pressure but saw the need to project their power into the region to maintain the rule of their dynasties at home. The opposing decisions of the UAE and Qatar after the Arab Spring is one of the major cleavages in today's Middle East (Davidson 2019; Kourgiotis 2020). Thus, it is safe to say that the Middle East saw processes of secularization and desecularization that resulted in a political landscape of deep and conflictual plurality concerning legitimate relationships of religion and politics.

However, the conflictual plurality is not restricted to a split within the Sunni community concerning the reaction to democratization, to Political Islam in general and the Muslim Brotherhood in particular, or to Iran and uprising Shia communities. There are many other cleavages vibrant in the region. Still dominant and spilling over into other areas and issues is the Israel-Palestine conflict. Last, but not least, the diverse Christian communities, ranging from the oldest Christian traditions, speaking the Aramaic language of Jesus to the Christian migrant workers from Asia and Africa, particularly in the Gulf Emirates, are part and parcel of the plurality of the Middle East (Stetter and Nabo 2020). Christian thinkers and politicians, such as Constantin K. Zurayk, held high-ranking positions in the pan-Arabic movement. They embraced secularism as a way to avoid Muslim dominance and saw Arabic nationalism as an opportunity to leave the inferior status they had in the millet system of the Ottoman Empire and become full citizens of the postcolonial nation states (Sabra 2006). Secular nationalism was, however, a troublesome solution for minorities as well (Mahmood 2016). While the nationalist Young Turks and Kemal Atatürk based their nation building project on religious and ethnic cleansing and homogenization in favor of a Sunni nation of Turks but chose a rigid laicism that imposed state control on religion, pan-Arabism was much more open to pluralism, and its secularism was much less rigid. It provided a political identity to which all religious fractions of society were supposed to belong. The terror reign of the Islamic state against various non-Sunni communities in Syria and Iraq, based on a kind of Sunni nation-building (Barbato et al. 2016), as well as the all-out campaign of the Alawite regime of Assad against the majority of the Sunni citizens of Syria, revealed the plurality of religious and ethnic belongings that secular pan-Arabism and the Ba'ath Parties of Syria and Iraq once tried to integrate, partly at the expense of the Sunni majority, in Iraq, particularly at the expense of Shias and Kurds. Already this very brief sketch of the history of the Middle East challenges the orientalist notion that only the West experienced secularization and desecularization deep enough to become ready for postsecular developments.

A postsecular society emerges when the religious cleavage loses its dominance due to a pluralist arrangement open to both religious and secular arguments. The debate about weaker or stronger versions of postsecularism was united in ruling out authoritarian claims but restricted itself to the rational deliberation of religious and non-religious arguments (Butler et al. 2011; Cooke 2007). Arguing for integrating authoritarian rule into the postsecular approach heavily compromises this normative demand. The argument here is not that authoritarian rule can be part of the postsecular ideal. Both the strong and the weak reading of the postsecular approach (Barbato and Kratochwil 2009; Chambers 2007) depend on the common ground that rational deliberation in contrast to authoritarian decision is the decisive point for the normative concept. The argument here is rather that postsecular developments 
can be observed even though they are part of a broader picture that is shaped by authoritarian rule and power politics. As the debate of Habermas' deliberative approach in international relations has shown, deliberations are islands embedded in strategic actions of power politics (Deitelhoff 2009). These insights have to be integrated in the debate about a postsecular society, particularly in international relations (Mavelli and Petito 2014).

Habermas' latest discussion of the entanglements of religion and politics and the historical emergence of a public sphere in Europe are illuminative for the argument here. Based on Rosenstock-Huessy's claim of a papal revolution in the 11th century (Rosenstock-Huessy 2013, pp. 516-61) and Bergman's discussion of this thesis with respect to the emergence of the rule of law based on canonical law (Berman 1995), Habermas argued that the popes' claim of supremacy over politics based on doctrine and law paved the way for accountability and delegitimized the self-understanding of emperor and kings that their bare will was already sanctioned by God as lawful. The clerical elite of the popes were able to push through remarkable parts of the papal program. In the entanglements of religious and political elites based on the doctrine of an ideological superiority of the clerics over the might of the warriors, an open public and the rule of law could emerge (Habermas 2019, pp. 637-75).

Obviously, the papacy or an equally unified and unifying religious actor does not play a comparable role in the Middle East. However, the emergence of rule of law, a critical pluralist public, and a tamed and accountable political power might not need unified religious balancing but only a pooled and pluralist religious counterpart. The decisive point for the effect of the papal revolution is less the institutionalized power than the claim to represent ideological supremacy without monopolizing political power. The popes tried to be influential and insisted on the entanglements of politics and religion, but, apart from the status of a prince in the Papal States, the popes never attempted to become political rulers of the space they tried to dominate doctrinally. This concomitance of a claim of ideological supremacy on the one hand and political abstinence and neutrality in favor of the rule of law and doctrine on the other hand opened up the space for a public sphere. It is well known that the history of the papacy has its dark sides of corruption and hubris. However, in some respect that is a sign for hope rather than for despair. It does not take constant saintly behavior on the side of religious actors and their institutions to trigger the emergence of the rule of law, a critical public, and the taming of political power.

Transferring these insights to the Middle East brings an essential argument into focus: the disentanglements of religion and politics, so often imposed on the Middle East and simultaneously lamented as impossible, are not necessary for normatively viable progress, but a powerful interreligious coalition of religious actors that claim public authority for the sake of the rule of law and a critical public but do not aim for revolutionary regime change in order to take political office by themselves is crucial. The claim here is not that a postsecular Middle East in this ideal sense is in the offing. However, the Arab Spring already showed opportunities in that direction, and most recently, the Document on Human Fraternity, signed by Grand Imam Ahmad al-Tayeb and Pope Francis, laid the programmatic ground for such an endeavor. The postsecular concept has to be tailored to detect these trends.

\subsection{Connolly's Postsecular Approach: Deep Pluralism and Politics of Becoming}

Two decades ago, William Connolly had already begun to criticize the rigid ideology of secularism because it does not provide, quite in contrast to its self-understanding, a common ground for everyone but excludes as a partisan project most of the religious members of the citizenry. While secularism offers a foundational ideology to integrate various world views, Connolly pleaded for a deep pluralism in order to find pragmatic compromises, not foundational consensus (Connolly 1999). The term of deep pluralism or negotiated pluralism invites us to trust in a society that differs fundamentally in various aspects of its creeds but is nevertheless able to find bridges and connect networks that construct viable social fabrics based on mutual respect, an open public, and the rule of law. However, such an endeavor comes with a prize for those who profit from the frictions of today. Connolly's term for such 
costly transformations is politics of becoming. Change is costly for those benefiting from established arrangements. Or, in Connolly's own words,

"The most complex ethical issues arise in those contexts where suffering is intense and its visitation upon some is bound up with securing the self-confidence, wholeness, transcendence, or cultural merit of others. That is, the most intense, intractable cases of suffering are political in character. They often revolve around what I call the politics of becoming" (Connolly 1999, p. 51).

The decisive question for the politics of becoming is the attitude of those who benefit from current arrangements. Do they trust in the promises of the transformation because they also see a role for themselves in the new arrangements, or not? A positive or a negative answer decides about fierce resistance or smooth transitions (Connolly 1999, p. 58).

Connolly's politics of becoming are open to the question of power. His approach has not enough trust in the pacifying force of reason to avoid the issue of exclusion by marginalizing the excluded strata as irrational. However, the idea of politics of becoming is framed as an emancipating project that should replace authoritarian exclusion instead of exchanging one authoritarian rule for another.

Power politics of becoming goes one step further. Again, the argument is not that authoritarian rule can be normatively justified but that an analysis of normatively meaningful postsecular developments is not to be disgraced because those developments are embedded in power politics or fostered and supported by actors who also intend to protect, stabilize, and legitimize their authoritarian rule. An expansion of the postsecular approach to the power politics of becoming is suitable for a fine-grained analysis without losing the capacity for a normatively sensitive evaluation.

\section{Postsecular Power Politics of Becoming on the Ground: Arab Spring and the Abu Dhabi Document on Human Fraternity}

From a normative as well as from an empirical perspective, the Arab Spring ended in a disaster. Only the forerunner Tunisia was successful in establishing a, at least, "flawed" democracy (The Economist 2020). While Algeria's experience of its civil war made it immune to any contagion effect, the thawing wind brought the Arab Spring eastwards. The authoritarian regime faltered and toppled, but democracy was not established. Whether the old dictators were killed, exiled, discharged, or kept in office, Libya, Yemen, and Syria were stuck in endless war, while Egypt returned to an authoritarian rule under a former general. Would the Middle East be a better place if the Arab Spring never happened? Looking at the death toll and the rise of the Islamic State, there is great temptation to denounce the uprising. However, the failure to establish a new order does not necessarily delegitimize the will of the people to resist corruption and oppression. Perhaps this experience of a postsecular revolution (Barbato 2012) might still form the basis for an emerging new order of the Middle East.

\subsection{The Postsecular Impact of the Arab Spring}

Postsecular revolution can be defined as taking place in order to end secularist, religious, and mixed regimes, which legitimize their authoritarian rules by the need to freeze the cleavage between more secular and more religious citizens or by protecting or excluding minorities defined by their belonging to a religious community or a religious ideology. A successful postsecular revolution can be defined by a new arrangement that cherishes various forms of religious heritage of the society without establishing an exclusivist creed to which all citizens have to conform, be it a civil religion, a traditional faith, or a comprehensive religious doctrine. The deep pluralism of a postsecular society takes differences seriously without fearing them. Postsecular societies trust that a politics of becoming that accepts these differences but delegitimizes differences of status and class, including the injustices of a corrupt regime, is better off (Barbato 2012, pp. 1081-83). More religious and more secular strata of the population, whether they organize their differences in parties or not, no longer understand this cleavage as a cause for civil war because an electoral victory of the other side is unacceptable. A losers' consent (Anderson 2007) is possible as the winning party is not trying to marginalize the interests and the existence of the defeated, and the next turn to the ballots could have an equally accepted different result. Only those extremists who 
do not accept these rules of the democratic game are marginalized and, if necessary, persecuted in due process of law. This is the ideal version. An extension to postsecular power politics of becoming can also see some progress within less ideal circumstances. Egypt can be understood as an example of this.

The broad alliance that protested against the elected Egyptian president Mohammed Morsi and the new Islamist but electorally approved constitution and later backed first al-Sisi's coup and then his election as president denied the losers' consent due to the game-changing character of the new rulers' constitution. Despite the suppression of the Muslim Brotherhood and others, which violated basic standards of human rights on a massive scale, al-Sisi could be understood as still being on a postsecular path, as he sticks to the view that he once stated in a term paper: "The moderate view is that there is a place of Islamic belief. [ ... ] A common religious understanding among all ethnicities and cultures must exist and there must be consideration given to non-Islamic belief" (El Sisi 2006, p. 11).

Based on these views, al-Sisi became the first Egyptian president who attended a Coptic Christmas Mass in 2015 (Kirkpatrick and Merna 2015). After the murderous attack on a church in 2016, he asked the parliament to lift the legislative ban on major new church buildings and commissioned the construction of the largest cathedral in the Middle East for the new administrative capital of Egypt. In 2019, it was inaugurated. Al-Sisi, a pious Sunni, was able to gain support from Sheik Ahmad al-Tayeb, Grand Imam of al-Azhar and a leading authority in Sunni Islam, who, similar to al-Sisi, visited the new cathedral and supported the right of Christians and Jews to have their buildings of worship protected (Reuters 2019).

Thus, the regime is still authoritarian and exclusivist in terms of marginalizing any kind of Political Islam or other dissenters by authoritarian means. However, the integration effort towards different strata of the population and the shift from secularist nationalism to an interreligious nationalism, bringing together Sunni Muslim and Copts, is a postsecular step forward. It seems to be feasible because al-Sisi, who was once brought into office as minister of defense by Morsi due to his piety, and the coalition that backed initially the military coup to support the continuity of the Arab Spring revolution were united on the common postsecular ground that religion should play a role in public and politics but not as a exclusivist comprehensive doctrine of Political Islam. Given the strength of Political Islam and the decline of secular pan-Arabism, a balanced postsecular society in the full Habermasian sense is not in the offing. However, the current authoritarian rule engages in postsecular power politics of becoming.

\subsection{The Abu Dhabi Delcaration of Human Fraternity}

Less than a month after the inauguration of the new cathedral, Al-Tayyeb met the Roman Pontiff and head of the Catholic Church, Pope Francis, in Abu Dhabi. The two religious authorities signed a declaration called the "Document on Human Fraternity for World Peace and Living Together" (Francis and al-Tayyib 2019). The document was framed as a global invitation of the two leaders to embrace the challenges of plurality in order to promote peace and fraternity among all people. The document presents an ambitious list of objectives, including hotly contested issues within the religious communities, such as religious freedom and equal rights for women. The global echo was significant. The long-standing papal efforts in this respect were honored (Barbato 2019; Gagliarducci 2019) but also sharply criticized, particularly by some inside the Catholic Church, as the document seemed to embrace religious pluralism, favored by some Church members but rejected by the magisterium of the Church. However, a closer look reveals that the alleged pluralist theology behind the document hints less to liberal Catholics than to Orthodox Quran teaching (Körner SJ 2019, pp. 615-17). In the driving seat of the document was not the papacy but the Muslim side, more specifically the Muslim Council of Elders, the Forum for Peace in Muslim Societies, and their Abu Dhabi host.

UAE strongman, crown prince Mohammed bin Zayed Al Nahyan, is the patron of the Muslim Council of Elders that consists of a board of senior scholars and former politicians. Al-Tayeb is the president of the council. An important member of the board and vice president is Abdallah Bin Bayyah, 
a former Mauritanian politician and Saudi Arabia-affiliated scholar, who is the founder and president of the Forum for Peace in Muslim Societies (Muslim Council of Elders 2020).

Abdallah Bin Bayyah's activities and affiliation shed a light on the controversies behind the declaration and what is at stake for the Middle East in a postsecular society that transcends secularist nationalism but is also post-Islamist (al-Azami 2019). Until 2014, he was vice president of the International Union of Muslim Scholars and close ally of the then-president Yusuf al-Qaradawi, an eminent scholar and public intellectual affiliated with the Muslim Brotherhood. The Egyptian is exiled in Doha, Qatar, where he has a prominent program on Al Jazeera.

During the Arab Spring and the following turmoil, Middle East scholars and rulers had to make some tough decisions. Due to the turmoil, the old alliances of scholars and rulers became unstable and fluid. Alliances had to be reaffirmed or reshuffled. The transnational public of the Middle East engaged in heavy controversies regarding how to adjust to the new situation. Muslim scholars, such as Yusuf al-Qaradawi and Abdallah Bin Bayyah, opted for different political and public alliances. However, not only scholars, but also rulers had to make decisions. Qatar opted for Political Islam and the open support of the Muslim Brotherhood. Abdallah Bin Bayyah broke with his Muslim Brotherhood partners and old friend Yusuf al-Qaradawi, who called for jihad in Egypt and Syria. Bayyah founded his own association, the Forum for Peace in Muslim Societies. It is based in Abu Dhabi under the patronage of the dynasty that opted for a stiff fight against the Muslim Brotherhood and its vision of an Islamic democracy. Bayyah, who is also a co-moderator of the World Council of Religions for Peace, is well-connected to the global movements of interreligious relationships (World Council|Religions for Peace International 2020).

One of the first new initiatives of Bayyah was the Marrakesh Declaration in 2016 that called for the rights and protection of religious minorities under Muslim rule, particularly in reaction to the terror of the Islamic State (Marrakesh Declaration 2016). One of the most important points was that devout Muslim scholars, not secularists, spoke of citizenship that had to include non-Muslims (Körner SJ 2019, p. 613).

Interreligious dialogue and an interreligious inclusive citizenship became an option for moderate Muslim scholars who were not willing to opt for jihad and Political Islam. This kind of interreligious pluralism became the postsecular alternative to pan-Arabic secularism and Political Islam.

Coming back to the question of the Muslim-papal relationship and the Abu Dhabi declaration, the real news with respect to the papacy is that renowned Muslims scholars and elder statesmen backed by powerful rulers were interested in joining forces with the papacy in a public diplomacy event to promote peace in the Middle East and strengthen Muslim identity as a peaceful nation, internally as well as externally. Even the Qatari state-funded broadcaster Al Jazeera was ready to pay tribute to the papal visit but also pointed at the human suffering caused by the war in Yemen, which was supported by the UAE (Al-Jazeera 2019). The interreligious outreach also seems to be, from a Qatar perspective, not a legitimate target to be criticized, even though the public papal mass on the sacred soil of the Arab peninsula could have been used as a reason for an outcry (Wood 2019). Nothing in this respect happened, however.

To understand the rationale behind the Abu Dhabi declaration, it is worth quoting the presented self-understanding of the council from the council's website:

"The Muslim Council of Elders is an independent international organization that was established in Ramadan 21, 1435 Hijri (18 July 2014) to promote peace in the Muslim communities. The Council unites Muslim scholars, experts and dignitaries who are known for their wisdom, sense of justice, independence and moderateness. They will work together to promote peace, to discourage infighting and to address the sources of conflict, divisiveness and fragmentation in Muslim communities. Based in the United Arab Emirates' capital, Abu Dhabi, the Council is the first institutional body that aims to bring the Islamic nation together by extinguishing the fire that threatens Islam's humanitarian values and principles of tolerance, and putting an end to the sectarianism and violence that have plagued the Muslim world for decades." (Muslim Council of Elders 2020) 
A council that focuses on inner Muslim unity and peace chooses an interreligious outreach in order to achieve its objective. The Document on Human Fraternity could, hence, be labeled as the manifest of a postsecular Middle East.

However, the objectives are in line with the UAE policy of founding a bulwark against Iranian hegemony and Political Islam. Scholars and rulers formed a broad coalition in order to frame and legitimize their policy and action on a new basis that embraces deep plurality. A pluralist and interreligious society backed by authoritarian rule in contrast to a Sunni majority democracy voting for Political Islam became a viable option for scholars and rulers alike. The entanglements of rulers and scholars are still too close to detect here the emergence of a critical public, such as the one Habermas attested to in the Papal Revolution of 1075. Nevertheless, inviting the pope, spanning an international and interreligious network, and integrating these efforts into a long-standing framework such as Religions for Peace are major steps towards an independent transnational public beyond authoritarian control.

Within half a year after the declaration, the papacy and the Council of Elders founded an interreligious organization, the Higher Committee of Human Fraternity, which also has a Jewish member. The committee's first major project is the erection of an interfaith complex in Abu Dhabi, called the Abrahamic Family House. The majestic compound will assemble a mosque, a church, and a synagogue and connect them below the surface with a conference center (The Higher Committee of Human Fraternity 2020). The postsecular impact coming from the Middle Eastern power politics of the becoming should not be underestimated.

\section{Conclusions}

Desecularization happens when secularist approaches lose their function of legitimizing power or no longer manage to exclude or restrict religion from or in the public sphere and political institutions. While Political Islam promised to integrate either the pious Sunni or Shia masses, which were excluded or whose participation was restricted under a secular regime, secular nationalism pretended to be strong on integrating diverse religious communities. The rationale of more or less secular interreligious coalitions of minorities, such as the Alawite dominated regime of Syria, is still to prevent the loss of vested rights to a religious, here Sunni, majority.

A postsecular politics of becoming overcomes this dichotomy without suspending the deep pluralism of the region. The plurality of the Middle East is becoming increasingly postsecular as public and political arrangements emergence that integrate more religious communities into public life and political participation without denying pious strata of the population participation on the basis of their creed, as long as they abstain from homogenizing politics as part of their politics of becoming. The traditionalist coalition, spearheaded by the UAE, Egypt, and the Muslim Council of Elders who signed the Document of Human Fraternity, seems to present a promising approach of a postsecular Middle East in that respect. However, the project is certainly embedded within a restrictive and authoritarian version of power politics of becoming.

Funding: This research was funded by the German Research Foundation/Deutsche Forschungsgemeinschaft (DFG), grant number: 426657443 .

Acknowledgments: I thank the three anonymous reviewers for their very helpful comments.

Conflicts of Interest: The author declares no conflict of interest.

\section{References}

al-Azami, Usaama. 2019. 'Abdullāh Bin Bayyah and the Arab Revolutions: Counter-revolutionary Neo-traditionalism's Ideological Struggle against Islamism. The Muslim World 109: 343-61. [CrossRef]

Al-Jazeera. 2019. Pope Francis Holds First Papal Mass in Abu Dhabi. Doha: Al-Jazeera.

Anderson, Christopher. 2007. Losers' Consent: Elections and Democratic Legitimacy. Oxford: Oxford University Press.

Asad, Talal. 2003. Formations of the Secular: Christianity, Islam, Modernity. Stanford: Stanford University Press. 
Barbato, Mariano. 2012. Postsecular Revolution: Religion After the End of History. Review of International Studies 38: 1079-97. [CrossRef]

Barbato, Mariano, Sinja Hantscher, and Markus Lederer. 2016. Imagining Jihad. Global Affairs 2: 419-29. [CrossRef]

Barbato, Mariano, and Friedrich Kratochwil. 2009. Towards a Post-Secular Political Order? European Political Science Review 1: 317-40. [CrossRef]

Barbato, Mariano P. 2019. Papal Dialogue with Islam: A Long Way to Abu Dhabi, a Long Way to Peace. Bristol: E-International Relations.

Berger, Peter L., ed. 1999. The Desecularization of the World: Resurgent Religion and World Politics. Washington, DC: Eerdmans.

Berman, Harold Joseph. 1995. Law and Revolution I. The Formation of the Western Legal Tradition. Cambridge: Harvard University Press.

Brown, Nathan J., and Amr Hamzawy. 2010. Between Religion and Politics. Washington, DC: Carnegie Endowment for International Peace.

Butler, Judith, Jürgen Habermas, and Charles Taylor. 2011. The Power of Religion in the Public Sphere. Edited by Eduardo Mendieta and Jonathan VanAntwerpen. New York: Columbia University Press.

Calhoun, Craig J., Eduardo Mendieta, and Jonathan Van Antwerpen, eds. 2013. Habermas and Religion. Cambridge: Polity Press.

Casanova, José. 1994. Public Religions in the Modern World. Chicago: University of Chicago Press.

Cesari, Jocelyne. 2014. The Awakening of Muslim Democracy: Religion, Modernity, and the State. New York: Cambridge University Press.

Chadwick, Owen. 1990. The Secularization of the European Mind in the Nineteenth Century. Cambridge: Cambridge University Press.

Chambers, Simone. 2007. How Religion Speaks to the Agnostic: Habermas on the Persistent Value of Religion. Constellations 14: 210-23. [CrossRef]

Connolly, William E. 1999. Why I Am Not a Secularist. Minneapolis: University of Minnesota Press.

Cooke, Maeve. 2007. A Secular State for a Postsecular Society? Postmetaphysical Political Theory and the Place of Religion. Constellations 14: 224-38. [CrossRef]

Davidson, Christopher M. 2019. The UAE, Qatar, and the Question of Political Islam. In Divided Gulf: Contemporary Gulf Studies. Edited by Andreas Krieg. London: Palgrave Macmillan, pp. 71-90.

Deitelhoff, Nicole. 2009. The Discursive Process of Legalization: Charting Islands of Persuasion in the ICC Case. International Organization 63: 33-65. [CrossRef]

El Sisi, Abdel Fattah Said. 2006. Democracy in the Middle East. Carlisle, PA, USA: U.S. Army War College.

Francis, and Ahmad al-Tayyib. 2019. Document on 'Human Fraternity for World Peace and Living Together'. Available online: http://www.vatican.va/content/francesco/en/travels/2019/outside/documents/ papa-francesco_20190204_documento-fratellanza-umana.html (accessed on 28 February 2020).

Gagliarducci, Andrea. 2019. Here Is Why Pope Francis' Trip to the UAE Is Benedict XVI's Vindication. Monday Vatican. Available online: http://www.mondayvatican.com/vatican/here-is-why-pope-francis-trip-to-theuae-is-benedict-xvis-vindication (accessed on 11 February 2019).

Habermas, Jürgen. 2006. The Future of Human Nature. Reprinted. Cambridge: Polity Press.

Habermas, Jürgen. 2008. Notes on Post-Secular Society. New Perspectives Quarterly 25: 17-29. [CrossRef]

Habermas, Jürgen. 2010. An Awareness of What Is Missing: Faith and Reason in a Post-Secular Age. Cambridge and Malden: Polity.

Habermas, Jürgen. 2019. Auch eine Geschichte der Philosophie: Band 1: Die okzidentale Konstellation von Glauben und Wissen. Berlin: Suhrkamp.

Habermas, Jürgen, Pope Benedict XVI, and Florian Schuller. 2006. The Dialectics of Secularization: On Reason and Religion. San Francisco: Ignatius Press.

Hegghammer, Thomas. 2010. Jihad in Saudi Arabia: Violence and Pan-Islamism since 1979. Cambridge and New York: Cambridge University Press.

Kaltsas, Spyridon. 2019. Habermas, Taylor, and Connolly on Secularism, Pluralism, and the Post-Secular Public Sphere. Religions 10: 460. [CrossRef]

Kirkpatrick, David D., and Thomas Merna. 2015. Egyptian Leader Visits Coptic Christmas Eve Service. New York Times, June 7.

Körner SJ, Felix. 2019. Die Geschwisterlichkeit Aller Menschen. Theologisch-Islamwissenschaftlicher Kommentar Zum Dokument von Abu Dhabi. Stimmen der Zeit 2019: 605-18. 
Kourgiotis, Panos. 2020. 'Moderate Islam' Made in the United Arab Emirates: Public Diplomacy and the Politics of Containment. Religions 11: 43. [CrossRef]

Mahmood, Saba. 2016. Religious Difference in a Secular Age: A Minority Report. Princeton: Princeton University Press.

Marrakesh Declaration. 2016. Available online: http://www.marrakeshdeclaration.org/ (accessed on 25 February 2020).

Mavelli, Luca, and Fabio Petito, eds. 2014. Towards a Postsecular International Politics: New Forms of Vommunity, Identity, and Power. New York: Palgrave Macmillan.

Muslim Council of Elders. 2020. Available online: https://www.muslim-elders.com/en (accessed on 25 February 2020).

Norris, Pippa, and Ronald Inglehart. 2011. Sacred and Secular: Religion and Politics Worldwide, 2nd ed. Cambridge: Cambridge University Press.

Reuters. 2019. Egypt's Sisi Opens Mega-Mosque and Middle East's Largest Cathedral in New Capital. Available online: https://www.reuters.com/article/us-egypt-religion/egypts-sisi-opens-mega-mosque-and-middleeasts-largest-cathedral-in-new-capital-idUSKCN1P00L9 (accessed on 7 January 2019).

Rosenstock-Huessy, Eugen. 2013. Out of Revolution: Autobiography of Western Man. Eugene: Wipf and Stock Publishers.

Sabra, George. 2006. Two Ways of Being a Christian in the Muslim Context of the Middle East. Islam and Christian-Muslim Relations 17: 43-53. [CrossRef]

Stetter, Stephan, and Mitra Moussa Nabo, eds. 2020. Middle East Christianiy: Local Practices, World Societal Entanglements. Cham: Palgrave Pivot.

Tamimi, Azzam, and John L. Esposito, eds. 2000. Islam and Secularism in the Middle East. New York: New York University Press.

Taylor, Charles. 2007. A Secular Age. Cambridge: Belknap Press of Harvard University Press.

The Economist. 2020. EIU Democracy Index 2019-World Democracy Report. Available online: https://www.eiu. com/topic/democracy-index (accessed on 28 February 2020).

The Higher Committee of Human Fraternity. 2020. Abrahamic Family House. For Human Fraternity. Available online: https://www.forhumanfraternity.org (accessed on 28 February 2020).

Wood, Graeme. 2019. The Vatican and the Gulf Have a Common Enemy. The Atlantic, March 1.

World Council|Religions for Peace International. 2020. Available online: https://rfp.org/about/leadership/worldcouncil-2/ (accessed on 25 February 2020).

(C) 2020 by the author. Licensee MDPI, Basel, Switzerland. This article is an open access article distributed under the terms and conditions of the Creative Commons Attribution (CC BY) license (http://creativecommons.org/licenses/by/4.0/). 


\title{
Article \\ Religion and International Relations in the Middle East as a Challenge for International Relations (IR) Studies
}

\author{
Anna M. Solarz \\ Department of Regional and Global Studies, Faculty of Political Science and International Studies, University of \\ Warsaw, Krakowskie Przedmieście 26/28, 00-927 Warsaw, Poland; asolarz@uw.edu.pl
}

Received: 25 February 2020; Accepted: 19 March 2020; Published: 24 March 2020

\begin{abstract}
This article addresses the search for religion's "suitable place" within International Relations (IR), taking as a starting point the social changes in the world ("reflexive modernity") and the postulated "Mesopotamian turn" in IR. The assumption is that religion is present at each level of IR analysis in the Middle East and, thanks to that, more and more at the international system level. This presence of religion serves to undermine one of the basic assumptions lying at the heart of the modern international order (and therefore also IR), i.e., the so-called "Westphalian presumption". The author, inter alia, emphasizes how more attention needs to be paid to the "transnational region" constituted by the Middle East-in association with the whole Islamic World. A second postulate entails the need for a restoration of the lost level of analysis in IR, i.e., the level of the human being, for whom religion is - and in the nearest future, will remain - an important dimension of life, in the Middle East in particular. It can also be noted how, within analysis of IR, what corresponds closely to the level referred to is the concept of human security developed via the UN system. The Middle East obliges the researcher to extend considerations to the spiritual dimension of security, as is starting to be realized (inter alia, in the Arab Human Development Reports). It can thus be suggested that, through comparison and contrast with life in societies of the Middle East as it is in practice, religion has been incorporated quite naturally into IR, with this leaving the "Westphalian presumption" undermined at the same time. The consequences of that for the whole discipline may be considerable, but much will depend on researchers themselves, who may or may not take up the challenge posed.
\end{abstract}

Keywords: religion in IR; Middle East; "Mesopotamian turn" in IR; "Wesphalian presumption"; levels of analysis; human security

\section{Introduction}

One of the greatest problems that social-science researchers face is the gap between theoretical considerations and the social reality they observe. Religion, which is very difficult to define ${ }^{1}$ and encapsulate at the theoretical level, is often overlooked in research, but this further widens the gap between theory and reality. Since religion still plays a very important role in people's lives, it has many functions to fulfill in the life of society, so its inclusion in research would seem to be an important challenge to take up. This is also true in the discipline of International Relations (IR), which-in line with the "Westphalian presumption" prevailing in theoretical considerations-considers religion a minor factor, usually to be excluded from analyses of international reality. Indeed, the lack of references

1 Also worth noting is the fact that, in the literature on religious studies, a conviction predominates as to the impossibility of this phenomenon being defined in a manner encompassing the world's religious diversity. This is a fundamental problem faced by research into religion. I follow the thoughts of specialists in religious studies in this regard, and also eschew any defining of the phenomenon at this point (Bronk 2009). 
to religion in the works most significant for the development of IR theories in the second half of the 20th century should actually be regarded as a feature characteristic of the discipline.

Although, in the wake of the events fed by "religious fuel" that have had a major impact on the international order in recent decades (especially the rise of religious fundamentalism and the September 11th attacks), IR researchers are dealing increasingly with religion in their work, no one really knows how religion ought to be anchored in the discipline, somehow in opposition to the "Westphalian presumption". Likewise, the author of this article cannot claim to have any comprehensive answer to that question, though she is seeking to use the present opportunity to open up further possible paths for exploration. Given the role and place of religion in its society, the Middle East provides an excellent pretext for discussion on the above topic. An additional impulse is provided by the "Mesopotamian turn in IR" postulated by Morten Valbjørn. In itself, this postulate does not constitute any new or revolutionary method of studying international relations. However, it does draw researchers' attention to the need to bring regional studies (in this case, Middle Eastern Studies) and IR closer together, with this serving to open up the latter to multidisciplinarity and a greater focus on historical and cultural aspects.

The method that I have deployed in this text for my research on religion in IR offers a combination of the postulate of the "Mesopotamian turn" and the IR approach, with this entailing an examination of the international reality at differing levels of analysis (the systemic, state, regional, transnational, and human). A novelty in this approach lies in the way that all are applied at once, though the limited volume of the article obviously precludes analysis of all relevant examples ${ }^{2}$.

The main goal here is therefore a demonstration of the way religion is present at each level of analysis in international relations vis-à-vis the Middle East and-thanks to that region-the entire international system. Crucially, this presence of religion serves to undermine one of the basic assumptions lying at the heart of the modern international order (and therefore also IR), i.e., the so-called "Westphalian presumption". I, inter alia, emphasize how more attention needs to be paid to the "transnational region" that the Middle East can be taken to constitute-in association with the Islamic world as a whole ${ }^{3}$. A second postulate entails the need for a restoration of the lost level of analysis in IR, i.e., the level of the human being, for whom religion is-and, in the nearest future, will remain - an important dimension of life, in the given region in particular. It can also be noted how, within analysis of IR, what corresponds closely to the level referred to is the concept of human security developed via the UN system.

The Middle East obliges the researcher to extend considerations to the spiritual dimension of security, as is starting to be realized-not least in reports on social development in the Arab World. It can thus be suggested that, through comparison and contrast with life in societies of the Middle East as it is in practice, religion has been incorporated quite naturally into IR, with this leaving the "Westphalian presumption" undermined at the same time. The consequences of that for the whole discipline may of course be considerable, but much will now depend on researchers themselves, who may or may not take up the challenge posed. The content of this article thus forms an aspect of research into religion within IR, as well as the Middle East, as placed within a wider dimension of sociological considerations vis-à-vis the condition in which today's world finds itself (termed "reflexive modernity").

In the context of the subject being addressed, the work particularly worth paying attention to has been and is by Shakman Hurd (2008), Philpott and Shah (2011), Thomas (2003), Fox and Sandler (2004), Telhami and Barnett (2002), Lee (1997, 2010), Kepel (2003, 2010), and Valbjørn (2004). It is also

2 For this reason, I omit the important case of Egypt and other countries in the region (e.g., Libya, Lebanon, or Yemen) in point 4.2 , which can be considered as some of the limitations of the article.

3 By the Middle East region, I basically mean the MENA (Middle East and North Africa) region, i.e., the Arab states, Turkey, Iran, and Israel. Apart from Israel, all of these countries are mostly Muslim and are part of the "Islamic world", which, in this article, I identify with the member states of the Organization of Islamic Cooperation. 
worth underlining the significance of the book "Islamic exceptionalism" by Hamid (2017), even as these theses have come under discussion recently in light of observed trends (Akyol 2019). In addition, the research on the Muslim state and society of the Middle East conducted by J. Zdanowski has proved very helpful (Zdanowski 2009, 2013, 2014). In this article, I have also made reference to United Nations Development Programme (UNDP) reports on social development, to work done by the Pew Research Center, and to the most recent polling data from Gallup. Particular emphasis has also needed to be put on a report from a group of specialists coordinated by Meddeb et al. (2017), which has been drawn up for the Barcelona Centre for International Affairs.

\section{Assumptions as to the Role of Religion in IR and Its Presence in International Relations in the Middle East}

Bearing in mind the use made of the above studies, it is worth the author establishing at the outset the identity of her own set of key research assumptions. On the one hand, these relate as such to the field that is International Relations, while, on the other hand, we find the matter of religion's role in the Middle East. Leading on from there, a further starting point holds that IR represents an intellectual construct built on "negative secularism" (Philpott and Shah 2011; Shakman Hurd 2008, p. 3). This would be to say that religion, as a conflict-generating factor destabilizing relations in society, has no raison d'etre in the international sphere. That would then be taken as meaning that this subject need not be researched. Such a conviction formed a basis for the so-called "Westphalian synthesis" (Philpott 2002), which has found its fullest reflection in IR via what Scott Thomas defined as the "Westphalian presumption" (Thomas 2003, p. 23).

And, while this approach reflected secularizing trends present in Western history and culture, it came to be seen as a point of departure for IR research in other parts of the world-and indeed worldwide-as well. Elizabeth Shakman Hurd can thus write of secularism holding sway in IR (secularism as "a form of political authority"). This means that it is through secular optics that researchers perceive and analyze international relations, putting into place complicated theoretical constructs that are nevertheless unable to account for many events and processes actually present or ongoing in societies (Shakman Hurd 2008, p. 3). But, the reality is that civilizational change, dubbed "Post-Modern", means an overestimation of the power of secularism in IR, with inappropriate "talking up" of the subject and with the real-life situation of the Middle East making a new view imperative.

Furthermore, the switching of attention to religion-and attendant negation of the "Westphalian presumption" from this perspective-may offer an opportunity for the discipline to find a better place for itself in the system of the sciences (Solarz 2018, pp. 118-20). Once the Iron Curtain had fallen, the circumstance in which the greatest interest was then invested in the history of the social system (also known as the international system), as what was assumed to be a source of comprehensive knowledge of the world we live in, led to "great expectations" being attached to IR as some kind of key to both diagnosing and resolving the problems societies faced as one millennium gave way to another. In this event, the onset of the 21st century saw IR not only failing to satisfy the trust placed in it, but in fact also facing perhaps the greatest challenges the field had ever encountered. In the face of a drawing-back of several different curtains previously shielding the world's cultural diversity from view, it emerged that accumulated knowledge on how the international system operates was far too superficial, and in fact unable to explain very much at all.

If hope is to be reinvested in IR at all, its knowledge will need to undergo reconstruction, this time on the basis of more profound and far-reaching study carried out at lower levels of analysis, and most especially at the levels relating to human aspirations, needs, convictions, and strivings. Efforts to incorporate religion can obviously be helpful as part of the aforesaid reconstruction, and-where IR in practice is concerned-this would denote expansion to accommodate a religious dimension on the part of the concept of human security that the UN system developed with reference to President Franklin D. Roosevelt's original "Four Freedoms". 
By adopting certain clear assumptions as to religion in the Middle East, we may present its role in that region's IR with greater clarity. In the first place, we should concur with Scott M. Thomas's observation that social research may not identify religion(s) with a doctrine subject to various different interpretations, but rather perceive the functions it (or they) actually serves (Thomas 2003, p. 25). Equally, R. Scott Appleby offered a pithy description of the dual role religion played in the life of society by resorting to the term "the ambivalence of the sacred". By this he meant that, while religion can bring quarrels, conflicts, and wars, it may do just the opposite by inspiring efforts to achieve peace, justice, and unification/reconciliation in its wake (Appleby 2000; Kulska 2013, p. 86; Solarz 2018, pp. 133-37). And, noting that, let us also recall that any impact of religion on IR (and, in particular, any positive impact) represents a fundamental contravention of the Westphalian presumption.

In the second place, as I focus on the role of religion in IR in the Middle East, I do not assume this is the only (or, in any case, even the main) force influencing the observable events and processes. Obviously, other ideative factors are present (not least nationalism and tribal or clan ties), as well as material ones (most especially of a geopolitical or geoeconomic nature) -with each influencing both the perceptions of reality and the decisions made, in this way being in a position to shape IR in this region. All of these phenomena, including the intertwined religion and politics, are mutually impactful and capable of generating or undergoing further change as a consequence of their being in operation see (Lee 2010, pp. 3-9). And that means that, where religion is ignored altogether, or even where its role is played down, the analysis obtained may no longer be considered to relate to reality as is.

In the third place, there can be no doubt that the Islamic World (and hence the Middle East) is playing host to a phenomenon that Maurits Berger terms "Islamization of the discourse". In Berger's view, this is taking on a paradigmatic form, in that what is being expressed in religious categories is even something not having a close link with religion, or frequently representing the abuse thereof (Berger 2010, p. 7). This denotes that IR researchers should be skilled enough to read things from the new narrative; hence, to possess basic knowledge of religion and to be in a position to re-evaluate the secularist approach that has so far held sway.

This can all be served if IR is able to turn back in the direction of regional studies (Valbjørn 2004). Here, it needs to be noted that what Morten Valbjørn postulated was a "Mesopotamian turn in IR" does at one and the same time denote a U-turn in the direction of religion (Schreiber 2012, p. 63). It also means the rejection of what certain IR researchers have come to see as the "Westphalian straitjacket" (Buzan and Little 2001).

On the other hand, the aforementioned "Islamization of the discourse" may also herald the development of the new phenomenon within the political Islam (Islamism) framework that is known as "post-Islamism". This is rooted in the idea that, in the face of the Arab Spring, but also the terror engaged in by Al Qaeda and ISIS/Daesh, the conviction that "the only way is Islam" has not stood the test of time. Changes of awareness of "Post-Modernism" in the Middle East are leading to an attitude sociologists term "reflective individualism" being taken up. The idea here is not to destroy existing structures and configurations, but to negotiate a space for freedom and unconventional behavior for the individual (Hanafi 2012; Zdanowski 2013, pp. 336-37). Such an attitude would seem to achieve reconciliation with a moderate version of religion, while emphatically neither negating nor abusing it.

\section{Reflexive Modernity in IR: "Westphalian Presumption" vs. "Mesopotamian Turn"}

The reflective individualism referred to above forms an aspect of broader civilizational change ongoing around the world. Sociologists consider that the onset of the "era of modernity" is to be linked to the process of collapse of the "old order" of the feudal society, which took place in the 17th and 18th centuries (Bauman 2004, p. 902). International institutions are, of course, rooted in the "Western culture of modernity" that has come into being since those days (Thomas 2003, p. 22)—which also means that it is their fate to be re-evaluated and undergo modification as that culture does the same. And part of this crisis of modernity can be seen to lie in the challenge religion currently seems to be posing for the social sciences (p. 22). 
The term "reflexive modernity" emerges as useful from the point of view of IR, given that it is based around a critical look being taken at oneself along with a willingness to address and correct mistakes one has been making (Bauman 2004, pp. 902-3). This would, in turn, denote that the trends associated with the departure along the road to modernity beginning in the 17th and 18th centuries, with development and progress in the direction of a life characterized by dignity and wellbeing, has served the good of humankind, but still needs reflection and some major course corrections if it is to be given effect in full.

In sociology, this approach has been termed the "revolution of the subject" or the process of individualization, and it is seen to link up with a retreat-on the part of those in authority-from earlier promises that they might solve all of society's problems (promises first, in fact, formulated in the period of classical modernity (pp. 907-8)). Given the 20th century's failed social experiments, the responsibility is now clearly to be shouldered by the individual, who naturally looks for support as he/she strives towards the goal single-handedly. In the cases of many people, that support may be offered by religion, which is often therefore lived and experienced in a deeper, more personal, way. To those on the outside, this phenomenon appears to be a religious awakening, a state of increased religiousness, or a return of (or to) religion.

A religious renaissance may bring with it an anticipated — and necessary—correction of modernity, thanks to the reinsertion of values that make the world more "humanity-friendly". In 1998, President of Iran Sayyid Muhammad Khatami chose the forum of the United Nations to put forward a concept of "dialogue between civilizations", through which religion could play a key role as a unifying and reconciling element see (Dzisiów 2006). Equally, if the (re)awakening links up with the sweeping criticism of modernity, seen as a manifestation of godlessness free of any values (Kepel 2010, p. 37), then the way is clear for the religious factor to exert a dysfunctional impact that does not liberate the human being in any way, but rather enslaves and inflicts much suffering. In the areas conquered by "Islamic State", efforts were made to portray widespread and total violation of human rights, inter alia by way of slavery and sexual violence, public executions, and the destruction of cultural heritage, as justified by historical and religious argumentation (Wejkszner 2016, pp. 109-12).

For its part, the Westphalian order in Europe-as shaped by the Reformation and the end of the Thirty Years' War in 1648-denoted a dominant role of the sovereign territorial state, and hence a ban on interference in its internal affairs, including recognized religion. In the light of bloody experiences with religious conflicts, this was-on the one hand-to guarantee rulers the freedom to choose a religion for themselves and their subjects, and-on the other-to end the curatorship of religious authorities (not least The Pope), ensuring their exile from worldly affairs. All of these elements together create the so-called "Westphalian synthesis", and they meant the privatization and marginalization of religion, and-where international relations were concerned-efforts to replace it by a cosmopolitan ethic, which Thomas described as the "Westphalian presumption" (Thomas 2003, p. 23). In the 19th century, the idea of the nation taking the place of religion came to be what bound the state together.

IR researchers saw such Westphalian principles as the foundation of modern international relations, not only on the Old Continent, but also everywhere in the world-and all the more so given the repeated reproduction of the model of the secular nation state as decolonization proceeded with the end of Empire. However, this took no account of actually existing historical and cultural differences, which emerged with renewed vigor as the Cold War came to an end in a period of the exhaustion of Western models that now seemed to have rather little to offer.

In the view of Thomas, the global (especially developing-country) religious awakening we observe is a manifestation of the search for "authenticity and development" (p. 22). As early as in the 1980s, Hedley Bull noted a further phase to the rebellion against the West, which he termed a "struggle for cultural liberation" capable of being viewed as a "reassertion of traditional and indigenous cultures in the Third World" (Bull 1984; Thomas 2003, p. 22). These phenomena only intensified in the 1990s, as it became clear that the modern secular states were not in a position to ensure their people's political participation, or, in fact, to solve their basic existential problems. The failure experienced by foreign 
cultural models became a pretext for people to fall back on their own tradition, hand in hand with a quest for authenticity and identity, as well as a simultaneous search for more dependable paths of development.

This all denoted a new political/policy approach in developing countries that Thomas describes as "an attempt to indigenize modernity rather than to modernize traditional societies" (Thomas 2003, p. 22; Lee 1997). As S. N. Eisenstadt observes, the reawakening of religion worldwide is not a harking back to traditional forms, but rather a forward-looking attempt to build "multiple modernities" in a Post-Modern world (Eisenstadt 2000; Thomas 2003, p. 23). The result of the changes is, in fact, to be something new for history, i.e., "a truly multicultural international society" (p. 23).

We may note the major chance for IR as a discipline that this all implies-with a synthesis of cultural and historical knowledge plus research of processes on the scale of the whole international system that would allow for real knowledge of that system and its evolution to be obtained. But difficulties linked with religion's incorporation into IR theory reflect the Western-centered nature of the discipline, which ensures that researchers in the world outside Europe use analytical instrumentation shoehorning the realities of society into categories and notions proper for Western culture, with these therefore being subordinated to the aforementioned "secular authority" (Hurd). The rebellion against that authority is thus one way for IR to achieve the tasks anticipated for it within the system of the social sciences.

In this light, it is worth looking at the postulate presented by Morten Valbjørn, who came out in 2004 with an incisive article, inspirational in terms of research, that made reference to the academic "Mesopotamian turn" referred to briefly above. In more detail, what he was referring to was an overcoming of isolation thanks to the opening up of creative dialogue between two "research streams", i.e., the "River of International Relations" (IR) and the "River of Middle East Studies" (MES). The researcher felt that, just as ancient Mesopotamia had become a cradle of world civilization thanks to the two rivers bounding its territory, so cooperation between IR and MES and the mutual enrichment that was made possible would found an "Academic Mesopotamia", fruitful in terms of future research thanks to its being fed by both streams. Those seeking IR's theoretical generalizations and focused on particular features of the region relevant to MES could-by way of mutual "irrigation" and "cultivation" - engender a better (as more universal) understanding of processes ongoing in the Middle East, while also conferring a new direction upon IR, in the face of continuing theoretical debate that often seemed very distant from the challenges raised by the international reality in particular parts of the world (Valbjørn 2004).

The "Mesopotamian turn" looked particularly apposite and up-to-the-minute in the wake of the tragedy of 9/11 (2001), when IR researchers had once again (for the second time in two decades) to face up to the fact that their discipline had overlooked key phenomena and processes that were essential if reality was to be explained and accounted for. As soon as in 2002, Robert O. Keohane-one of American IR's leading authorities—questioned the suitability of analytical models and theoretical assumptions holding sway previously when it came to explaining the reality of the international situation made plain by September 11th. He, in essence, suggested that academics had been taken in by their own theories. In his view, the attacks on America revealed that " $(\ldots)$ all mainstream theories of world politics are relentlessly secular with respect to motivation. They ignore the impact of religion, despite the fact that world-shaking political movements have so often been fueled by religious fervor" (Keohane 2002, p. 272). Keohane simultaneously confessed to his own incompetence where the study of religion was concerned, stating that he would leave the matter open for explanation by other researchers (p. 272). In these circumstances, the utility of regional studies looks very clear.

Let us now note how, from the point of view of IR, the "Mesopotamian turn" denotes a questioning of the "Westphalian presumption", and a necessary reorientation thereof, inter alia in a direction that provides for its incorporating religion. Understanding their region better, those researching within MES emphasize that the Middle East may not be analyzed if no account is taken of the functions that culture and religion there serve (Valbjørn 2004, p. 55). It further needs to be stressed that the impact of religion has "spilled over" beyond the region, permeating into the international system that is the 
main subject of IR research. There, it meets up with the influence religion also exerts in other parts of the world, such as America, Africa, Asia, or Eastern Europe.

The difficulties with bringing religion into IR relate on the one hand to the discipline's Eurocentrism, and especially the assumption that each state in each region of the world (Middle East included) reflects the European progenitor. On the other hand, there is the reality that research has first and foremost seen things from the point of view of the state and the system. Only to a lesser degree has the transnational and regional level been taken account of, while the level of the individual has apparently been abandoned entirely.

\section{The "Westphalian Presumption" and the Reality of the Middle East-A Perspective Relating to Different Levels of Analysis}

IR's apparent identification of different levels of analysis of the same processes and international events can be researched from different perspectives that allow for a better encapsulation of what is involved and how this has evolved. The popularization of the above approach in the late 1950s and early 1960s was very much the contribution of K. N. Waltz, M. Kaplan, J. D. Singer, and others. The first of these analyzed classical literature devoted to the issue of war and noted how the causes of conflict might be sought in three different sources, i.e., human nature, the nature of the state, and the nature of the international system (recognized as anarchy) (Waltz 1959).

As IR developed, this methodological approach evolved. On the one hand, new levels of analysis appeared, albeit with the level of the individual treated as obsolete see (Singer 1961) —even though it plays a major role in the theory of foreign policy seen from the point of view of decision-making. On the other hand, under the influence of IR's incorporation of both constructivism and alternative theories (alongside the classical approach), leaving the state and material factors as the centers of attention, there appeared analysis of the influence of other entities, as well as factors underpinning identity, including ideas, norms, and values impacting international relations.

These changes were favorable from the point of view of research into religion in IR, as they prepared the ground for a re-evaluation of the Westphalian synthesis and a weakening of the "power of secularism". Thanks to the "Mesopotamian turn", religious consideration could impact upon IR's further evolution, with a way of achieving this being the reanalysis of the religion's presence from the point of view of different levels of analysis.

\subsection{The International System Level and Religion in the Middle East}

It was at the level of the international system that the principles of the Westphalian system originating in Europe were injected and continue to operate. The process began with the UN Charter's enshrining of the principle of state sovereignty and equality, and, in consequence, the doctrine of non-interference in states' internal affairs. In line with the "Westphalian presumption", religion remains beyond the sphere of interest of international institutions, even as it seems that a gradual change in this approach has occurred-thanks to a process in which these principles are set against the practice that can be seen in society. I would point to examples that at the same time portray the "ambivalence of the sacred" after Appleby.

An example of a positive impact of the factor of religion might be furnished by the aforementioned "Civilizational Dialogue" concept put forward by Khatami, whose basis is to be looked for in dialogue between religions. The Iranian President, who resembles most dignitaries in his country in having a theological academic background, made no attempt to hide this fact, and in fact sought to woo other religious leaders, not least during a meeting in The Vatican with Pope John Paul II. The initiative of the Iranian President garnered support from other Muslim states, which in May 1999 adopted the Tehran Declaration on Dialogue among Civilizations (Declaration text: Segesvary 2000, p. 99). And, while this text does not especially expound the role of religion, there can be no doubt that what lies at the heart of the Declaration is a desire to perpetuate a positive image for Islam in international relations. 
The relevant task at the level of the international system is the objective the organization that offered a forum for adoption of the above Declaration set for itself. This is, in fact, the only intergovernmental institution founded upon and grounded in religion. It appeared in the late 1960s and early 1970s on a wave of initiatives seeking to unify the Muslim Community, and has been known since 2011 as the Organization of Islamic Cooperation. This is, in fact, one of the largest organizations in the world of a non-universal nature. Here, documents signed up to by the governments of as many as 57 Muslim states always commence with an invocation of God, and are a manifestation of a deep conviction that Islam offers a resilient link bringing together countries often distant from each geographically, economically, and politically, and even in conflict with one another.

Yet the very existence of this international relations entity and whole system of associated institutions featuring the adjective "Islamic" poses a serious challenge to a Westphalian synthesis precluding cooperation of this type in a world made up of modern states. This may explain how the Organization of Islamic Cooperation (OIC) has received little attention from IR, which indeed skirts around the fact that we have here a four-continent structure that is a strong and often influential voice at more conventional international institutions, while entirely capable of coordinating cooperation among members in matters of importance to Islam (Gieryńska 2017).

The initiative from a Shiite cleric found fertile ground in the immediate aftermath of the September 11th (2001) attacks. It was as early as in the November of the same year that UNESCO adopted unanimously the Universal Declaration on Cultural Diversity, while the General Assembly passed the Global Agenda for Dialogue Among Civilizations (2005). This was to be the international institutions' response to religious and cultural conflicts proliferating as a consequence of Islam-linked terrorist attacks. Muslim states of the Middle East, in fact, played host to several meetings relating to the above initiative, e.g., in Yemen (in 2004), Iran (2005), and Morocco (2005). An International Center to promote the Civilizational Dialogue gained the support of the European Parliament, among others (Dzisiów 2006). In 2004, the initiative also received the backing of Turkish leader Recep Tayyip Erdogan (in cooperation with the Prime Minister of Spain), while, in 2005, the United Nations Alliance of Civilizations (UNAOC) was called into being, and has since collaborated closely with such bodies as the Committee of Religious NGOs at the United Nations, Religions for Peace, and the United Religions Initiative.

While researchers draw attention to the vanishingly limited direct influence these initiatives have on international life, it is necessary to note their significance for the evolution of principles in the international system, as well as for theoretical thinking in IR (with the concept even being termed "the new paradigm") (Solarz 2007, p. 83). The concept of the Dialogue Among Civilizations offers a more positive image of religions, perceives and emphasizes a positive role that can be played, and, in so doing, undermines the "Westphalian presumption".

A second example undermining the Westphalian synthesis at the level of principles of the international system is linked with the negative impact of religion in the Middle East and involves an intensifying wave of persecution mounted against religious minorities. The guaranteeing of religious freedom-certainly an element of the above synthesis-emerges as difficult to make real in the non-Western, non-Christian world. In recent years, the numbers of states in which such persecution takes place has increased (from 58 in 2017 to 73 in 2018), with an attendant increase in numbers of people facing this problem-from 215 to 245 million (Christian Persecutions 2020). Persecution in the Middle East afflicts the followers of various different religious minorities, but Christians suffer in particular (Pew Research Center 2018), being deprived of their homes, killed, abducted, jailed, and discriminated against. According to a report prepared for the UK's Foreign and Commonwealth Office, cases of persecution are linked to Middle-Eastern sectarianism, with the parties directly answerable for this being governments (especially in Saudi Arabia and Iran, and latterly also Turkey and Algeria), armed groups of Muslim extremists (especially the so-called Islamic State, whose actions have all the hallmarks of genocide), and, in many places, also local communities (Bishop of Truro's 2019, p. 8). A simply alarming situation is being faced by Christians in Algeria, Egypt, Iran, Iraq, Syria, and Saudi 
Arabia. Meanwhile, the share of the population of Israel that is Christian has fallen from $15 \%$ to $2 \%$ (Bishop of Truro's 2019, p. 8).

Post-2011, religious extremism has, in particular, taken its toll among the Christians and other religious minorities of Egypt, Syria, Iraq, and Libya. A particularly difficult situation is faced by converts from Islam to Christianity, who, in particular, suffer persecution throughout the MENA region (pp. 8-10). Violations of religious freedoms are favored by a lack of legal protection in the Middle East (p. 10), notwithstanding the guarantee offered, inter alia, by the International Covenant on Civil and Political Rights-in fact, signed up to by most countries in the region (AHDR 2004, p. 108). Discrimination hits not only the indigenous Christians of the Middle East, but also economic migrants from other parts of the world (especially Asia) - who now constitute a noticeable share of the entire populations of the Gulf States (between 4.4\% in Saudi Arabia and 14.5\% in Bahrain) (Meddeb et al. 2017, p. 24).

The situation in regard to the persecution of religious minorities arouses disquiet at the global level, as can be seen from the declarations and instruments of law adopted and monitoring institutions set up. Despite freedom of conscience and freedom of religion accompanying the UN system from its earliest days, a binding Convention regarding this matter has never actually been adopted, even though 1981 did see the General Assembly enact the Declaration on the Elimination of All Forms of Intolerance and of Discrimination Based on Religion and Belief. Indeed, the post of the UN Representative for religious freedom was established (known since 2000 as the Special Rapporteur on Freedom of Religion or Belief), and there are also independent experts.

The USA became involved in the protection of persecuted religious minorities, with Congress in 1998 adopting the International Religious Freedom Act aimed at the worldwide promotion of religious freedom within the framework of US foreign policy. A post of Ambassador-at-Large for International Religious Freedom was instituted at the State Department, which was, i.a., to run negotiations with different states on this matter. A Commission on International Religious Freedom (USCIRF) was also established, with a mission to report and with a Special Adviser appointed within the National Security Council framework.

Likewise, the EU, while declaring its external policy secular, is nevertheless pursuing "religious engagement" in a circumstance of ever-greater awareness of the impairment those adopted assumptions denote. Awareness of "religious illiteracy" has been growing ever since the 2006 "Danish cartoon" crisis, though it was the phenomenon of revolt in the Arab World and of conflict in Syria that prompted the change of approach. In 2013, the EU Council adopted Guidelines on the promotion and protection of freedom of religion or belief (Council of the European Union 2013), which, i.a., found their reflection in training in religious affairs European External Action Service (EEAS) diplomats received, as well as in an annual report from the European Parliament Intergroup on the State of Freedom of Religion or Belief in the world (Wolff 2018, pp. 161-62). These activities would themselves denote a breach in the hitherto Westphalian approach taken by the EU institutions.

The problem of religion at the level of the international system, in large measure generated by the Middle-Eastern region, is therefore a present one in every sense, exerting a growing influence on the above system's evolution. We may note that-between the two key components of the Westphalian synthesis that are non-interference and the delivery of freedom of religion-there is an inherent conflict, and one that is growing. The security-related issues that cause the above freedom to be violated encourage a recognition that the said interference or intervention might indeed take place, in line with the "responsibility to protect" - and that is a further breach of the impenetrable wall once known as the Westphalian synthesis.

\subsection{The Level of the Nation-State and Religion in the Middle East}

As the systemic conceptualization present in work on IR denotes reductionism, many researchers in this field prefer analysis at the level of the state (albeit treated as an element within the international system), with the prism being the achievement of state interests (as regards security, wellbeing, and 
order in society) (Łoś-Nowak 2013, p. 15). The approach is, in fact, taken by many researchers dealing with the Middle East, with different levels of Foreign Policy Analysis (FPA) often deployed (see Kostecki (2013); see Hinnebusch and Ehteshami (2014), Korany and Dessouki (2010)).

The foreign policy of a state has its sources in its interior, and it is there that it takes its inspiration. It is at the level of home affairs or domestic policy that state interests are most often defined, though things are also obviously influenced by external conditioning, including the international structure. In terms of its principles, the system remains wedded to the Westphalian synthesis, so elements of the system are expected to pursue those principles. Simultaneously, in both the domestic and foreign policy of states of the Middle East, the factor of religion is present-and often "in collision with" the secular system. Causes of this may be sought in the process by which the modern states in this region took shape-a process in which religion played an entirely different role from the one it played in Europe. This is, in fact, true of both Muslim states and Israel. Religion was present at the very root of the process shaping the contemporary identities of different Middle Eastern states (Solarz and Bobińska 2018, p. 21). As history and cultural trends did not lead to its rejection, the Westphalian synthesis is negated even at this stage. The emergence of the nation-state was thus a construct imposed by ruling elites who had in every case to organize their attitudes toward the religion still playing such a key role in society.

Other than Turkey, which declares itself a secular state, virtually all of the region's other countries replicate a pre-modern system in which the powers that be anticipate their decisions gaining the approval of religious authorities. This denotes a fundamental assumption to the effect that the law in force in the state may not contravene religious law (Sharia or Halakha), and that is a clear and important difference from the Western system. On the other hand, the official religious institutions in the pay of the government have to submit to a measure of control of one type or another, with the intention here being to prevent religion from developing in directions regarded as undesirable from the state's point of view.

Attesting to "Islamization of the discourse" in the Middle East's Muslim states is the fact that religion often offers grounds for political battles. It is also dominant in political rhetoric-with both oppositions and governments invoking Islam to achieve credibility and support among the people. Iran's 1978-1979 revolution against dictatorship and the repressions of the Shah was mounted in the name of freedom, in this way bringing together various opposition forces. What emerged as decisive, however, was the nationwide religious authority enjoyed by Ayatollah Ruhollah Khomeini, a Shiite cleric who established and introduced the concept of Velayat-e faqih in Iran. The Constitution of the country provides that: "Absolute sovereignty over the world and the human being belongs to God" (Art. 56). In the Shiite conviction, the head-of-state role falls to an Imam. Should he be absent, the state is led by the leader or marja'-e taqlid-the Grand Ayatollah, who is an Imam selected by clerics on the Council of Experts from among those regarded as most competent. God's sovereignty in the Iranian system is linked with the sovereignty of the people, who also elect representatives-a President and the Majles, or Consultative Assembly. However, concordance between what the Assembly enacts and the strictures of Islam is checked for by a special body known as the Guardian Council, made up of six clerics appointed by the leader. While this whole concept was included in a Constitution enacted democratically and adopted by popular demand in a Referendum, it is hard to reconcile this in any way with the "Westphalian presumption".

The political role of religion is also attested to by the fact that, where free elections take place, religious parties often win. This was the situation in Algeria (1990-1991), Turkey (2002), the Palestinian Autonomy (2006), Tunisia (2011), Egypt (2012-2013), and Morocco (2011). In Lebanon since the start of its statehood, and in Iraq since 2005, the division of power in place has been between different ethnic and religious groups. The year 2018 saw Hezbollah strengthen its position in the Lebanese Parliament greatly, to the extent that a return to government was made possible. In Israel, the religious parties have joined coalition governments ever since that state first existed, and have mostly held the balance of power. Since 1977, when Israel's right won the election, their significance has been even greater. 
Robert D. Lee notes four ways in which religion makes itself felt in all of the Middle-Eastern states he analyzed (i.e., Egypt, Israel, Turkey, and Iran), i.e., through identity, ideology, institutions, and political culture. He thus states that: "Politics has shaped religion as much as or more than religion has shaped politics" (Lee 2010, p. xi). Observers of the political should thus track changes in religion and religiousness, given the way that this impacts upon politics and vice versa. This is also made clear by the case of Turkey, which has spent a century passing along a very long road from the political function of religion in the Ottoman state (as especially attested to by an attempt to consolidate the Sultan's power around pan-Islamic ideology), via a secular nation-state, through to today's post-secular Turkey. Today, we observe a renaissance for Islam's political role in this state (neo-Ottomanism), but without any absolute disruption of the continuity with the secular past. The protection of Muslims and religion and the aid for fellow believers in need have, in fact, become key planks of Turkey's foreign-policy platform (Tabak 2017).

A contrast with Turkey is provided by the Middle-Eastern monarchies, in which an emphasis on links with Islam at the dawning of independence was to serve in legitimizing a King's authority. Thus, one of the titles held by the King of Morocco is "Commander of the Faithful", while the fact of his descending from the Prophet is regarded as confirming his religious authority. The King's public prayers and declarations form a kind of state ritual. Today, given the presence of religious extremism, the King sees it as his task to promote a moderate, tolerant, and peaceful Islam. In this, he naturally wins the support of the international community, and especially in the EU, which has many of its hopes riding on Morocco. This situation sees the King supporting the Civilizational Dialogue initiative, and schooling his Imams in the specially-founded Mohammad VI Institute, whose theological and legal courses are accompanied by training in the social sciences and history. The Institute's courses are also open to participants from Africa, the Middle East, and Europe (a special understanding in this matter has even been signed with France). While domestic politics does see issues arise with an Islamist opposition whose activities are legal, the moderate version of Islam can be regarded as a Moroccan "product for export", and does represent a major plus-point of its foreign policy. His Majesty also propounds and supports a concept of "spiritual security" (Meddeb et al. 2017, p. 9), which can be regarded as Morocco's contribution to the aforementioned efforts to inject a dose of religion into human security.

The basis of Saudi Arabia's political system is an alliance formed between rulers from the House of Saud and descendants of Muhammad ibn Abd al-Wahhab, an 18th-century religious reformer. The Ulama are present in the immediate vicinity of the leader and influence all of his key decisions, which need to be sanctioned from the religious point of view. Given that this is a country whose income from oil rose dramatically from the 1970s onwards, Saudi Arabia was faced with the dilemma of how to reconcile its newfound wealth with an ongoing declared attachment to a Puritan version of Islam (Ochsenwald 1981, p. 274). In line with the latter, all wealth belongs to Allah and the Ummah He leads. Money has thus been assigned in support of the pan-Islamic movement, and this was anyway in the interests of the ruling dynasty. As early as in 1926, 60 delegates from around the Muslim world meeting at Mecca (and including diplomats and religious leaders) conferred upon Abdulaziz ibn Saud (as founder of the Saudi state) the responsibility of safeguarding Islam's holy places in Mecca and Medina. Called into being at that time was The World Muslim Congress, which convened in Mecca during the Hajj each year through to the outbreak of World War II. The idea of the Congress was returned to in 1949, from which time it operated under the abbreviated name of Motamar.

It was in large measure the determination of Saudi Arabia's King Faisal that ensured the appearance of today's Organization of Islamic Cooperation. Saudi Arabia is also the patron of an NGO that came into being in 1962 under the name World Muslim League. The organization was to symbolize the unity of the Muslim world, while also backing Saudi interests in confronting the influence of Nasserism and other radical secular ideologies appearing in the region. Enjoying Saudi financial support, the League now has many different branches around the world, and backs mosque construction, the dissemination of the Holy Koran, and assistance for Muslim minorities. In this way, it has become one of the 
key centers propagating Islam in its Wahhabi version. Also associated with this organization is the International Islamic Relief Organization; in existence since 1978, it is the largest Islamic organization of its profile, cooperating with many other bodies and governments around the world, and active in many countries in Africa, Asia, Europe, Latin America, Caribbean, and North America (UNHCR 2020).

In the eyes of decision-makers in Israel, Iran as the supporter of movements seeking a radical form of Islam (who stand accused of terrorism) poses the greatest threat to both Israel and the world as a whole. Israel's efforts thus seek to discredit Iran and achieve its total isolation. One aspect of this policy sees the religion in Iranian politics presented as Medieval superstition to be contrasted with the "enlightened" approach taken by Israeli politics. Prime Minister Netanyahu typically describes his country as the sole democracy in the Middle East. The reality that emerges from all this is much more complicated, however, as the "enlightened" Israel is becoming more and more "Jewish" —in the religious and national senses at one and the same time- since there is no way to separate the two components in this case (Solarz 2014, p. 89). In a clip justifying the August 2019 pre-emptive strike that the Israeli Defence Force launched against Syria, Netanyahu cited a Talmudic dictum relating to self-defense: "If someone rises up to kill you, kill him first" (Blum 2019). While this might be regarded as a typical example of rhetoric going out live, a careful examination of Israel's domestic and foreign policy makes it hard to avoid the conclusion that Judaism is a constant presence, finding its reflection in the "religion of security" adhered to by Israel's leaders and a great part of its society (Jones 2002, p. 136; Sandler 2018).

Religion is a constant presence in domestic and foreign policy in the Middle East since, from the moment that the region's modern states took shape, it was an inseparable element of their identity, even as this initially went almost unnoticed by IR studies. The prevalence of the "Westphalian presumption" required that religion be treated as an aspect of (matter for) domestic policy, with this factor not needing to be exposed where foreign policy was concerned. The fact that this presence sooner or later made itself felt in the Middle East only attests to the way in which there was never any full implementation of the Westphalian synthesis in this region.

\subsection{The Regional and Transnational Level of Analysis and Religion in the Middle East}

In the Middle East, the process of transition from a Millet-, clan-, and tribe-based system to modern states did not happen by evolution, but was rather mostly a matter of manipulation and ideological impacts, including elite-imposed top-down modernizing of societies in line with European models. This was particularly visible with the reforms instituted by Atatürk or Reza Pahlavi, but was present to a greater or lesser extent in every country in the region. Far-reaching Westernization and the placing of Islam on some kind of "back burner" naturally raised resistance among Muslims attached to their religion (Zdanowski 2014, p. 222). It was in such circumstances that (in 1928) there arose the Muslim Brotherhood in Egypt—out of the idea of the Al-Nahda or "Arab renaissance". The Brotherhood's impact in fact extended beyond the state borders, offering a basis for the first transnational movement invoking Islam. Its appearance was a response to the chaos arising after the end of the Caliphate, but also to real social need that people outside a corrupt narrow elite had to contend with (Kepel 2003, p. 33). From the very outset, there was very strong linkage between these two (religious and social) dimensions where the activity of the Brotherhood was concerned, but also in people's lives.

By making use of IR analysis at the level of the region or transnationally, it is possible to note how the vision of a return to Islam as the foundation of the Muslim "nation" (or Ummah) and universal social order (via the "Muslim path to development") can represent an alternative approach to the European one based around the nation-state, democracy, and modernization as linked with secularization. This can, in fact, be regarded as a regional alternative to the "Westphalian presumption", and one that can be given effect within the framework and context of a transnational Muslim region.

This concept of the "transnational region" appears in the work of E. Adler, relating to a so-called "new regionalism" wherein attention as a region emerges is paid not so much to geography and regional organizations, as to common values, norms, and political practice (Adler 1997; Zajaczkowski 2013, p. 67). 
Governments are not the sole carriers of this idea, given the involvement of organizations in society whose ranges are not confined to single countries. An approach taking this into account would seem to be of great assistance to the study of the role of religion in IR, given the way it allows for a bringing-together of two levels of analysis important from this point of view, i.e., the regional and the transnational. We may note that the Middle East as a region defined classically is a component part of a transnational Islamic region whose boundaries are set by religion. On the one hand, there is affiliation with the OIC, and on the other, transnational organizations and associations created in bottom-up fashion by Muslims across this whole area (starting with the Muslim Brotherhood).

In the classical regional conceptualization, a Middle East whose core comprises Arab states tended to be described in the literature as a "region without regionalism" (Aarts 1999; Coskun 2005). For, despite the geographical location, the very close links between most states, and the existence of an intergovernmental organization in the shape of the Arab League, it is hard to speak of a regional system in this part of the world. There is not much sign of ongoing economic or political cooperation (with "regional projects" including ambitious attempts to create single political or economic organisms so far doomed to rapid failure), while the region continues to struggle with deep conflicts and divisions. Beyond the Arab-Israeli conflict, there are numerous wars in the core sector, i.a. in Iraq, Syria, Libya, and Yemen. Nor is the situation calm in either Algeria or Lebanon, while Saudi-Iranian rivalry, the ambitions of Iran, Turkey, and Qatar, and even the Kurds' struggles for independence all encourage reflection as to the futures of this area's nation-states.

If we then overlay upon this depiction of the region a transnational level of analysis (i.e., by taking account of such transnational situations as the operations of the so-called Islamic State), it emerges that destabilization and internal conflicts in the different countries, but also existing forms of cooperation, are regularly caused by the same phenomena and interlinked entities that take shape beyond the borders present on the map. And many of these hark back to religion.

Also noteworthy here is the fact that, while the wealth flowing from the exploitation of the world's richest deposits of oil and gas is distributed in a very uneven way, the condition society across the Arab world finds itself in is similar, as Arab Human Development Reports published by the UNDP since 2002 make clear. These Reports conclude that, in connection with events unfolding in the region (since late 2010 in particular), the Arab world finds itself in serious socio-economic crisis. However, the means and methods international institutions advocate to tackle this either prove unacceptable to people (because of their social costs), or else are undermined by ruling elites, who seek to maintain a Westphalian-system façade at any cost, in order that they may hang on to their posts. Yet the difficult social and political situation leaves the Middle East as the Westphalian order's ticking time-bomb. The moment of explosion remains hard to predict, but the signs that this is coming look clearer and clearer.

The social problems international reports have proved capable of diagnosing are not always noticed by the authoritarian regimes in power in the Middle East. This guarantees the popularity of centers rendering assistance to the needy or offering them support, which typically engage in their activities in line with the dictates of religion. Spheres of operation thus include charity in general, religious education, and social work-all in association with a conviction that, since almost all Muslim states have adopted secular codes of law alongside Sharia, have pursued more- or less-tangible cultural reform, and have approximated Western models (e.g., in regard to traditional social roles), the stagnation present now can only give way to real development if there is a return to a "Muslim path to development" that has been departed from.

Thinking in terms of political Islam (Islamism) is thus very popular through much of today's generation (Zdanowski 2009, pp. 15-17), though prescriptions vary in line with the degree of "radicalization" that has taken place. Islamism has its moderate current (usually eschewing violence and open to the idea of participation in the political process (Meddeb et al. 2017, p. 10), and often linked with the Muslim Brotherhood), as well as a more radical Salafist one, whose extreme faction takes the form of the Jihadism, advocating violence in the name or religion. Radical manifestations of Salafism have been Al-Qaeda and Daesh (IS). This is, of course, a rather simplistic division, albeit 
one inscribed in the concept of the "ambivalence of the sacred", with moderate Islam being a good solution for Muslim societies with politicians thereby seeking to promote it, while Jihadism is usually responsible for war and terrorism and poses a threat to the world.

We may note that the political Islam of various different currents is a supporting ideology invoked by organizations and associations of more-than-national reach. These build up a dense network based on interrelatedness and cooperation, but also conflict, on the transnational level. As their area of influence relates in particular to the OIC states, we may use two levels of analysis in IR-regional and transnational—-to distinguish a "transnational Muslim region". Within this, the Middle East has a strong representation, in particular given the broad scope of impact of the first Islamist-type organization, i.e., the Muslim Brotherhood, which now has its branches, spin-outs, and sympathizers around the world.

Eventually defeated by an international coalition in March 2019, the so-called Islamic State (ISIS/Daesh) posed the greatest challenge so far to the Westphalian order in the region, which was genuinely under threat. Reviving the idea of the Caliphate, it offered other socio-political solutions that referred to Islam and its adherents' aspirations where international relations are concerned. At least 20 different Jihadist groups from around the world swore allegiance to the Caliph during the period November 2013 to January 2016, with the consequence that a succession of provinces from around the Muslim world (e.g., in Indonesia, Pakistan, India, Iraq, Algeria, Egypt, Tunisia, Yemen, Libya, Uzbekistan, the Caucasus, and even Nigeria and The Philippines) joined the self-declared "State" (Wejkszner 2016, pp. 36-41). However, thanks to the methods of implementation it chose, to put the undertaking into effect, IS could not gain the willing support of most Muslims. Nevertheless, the role that religion played in this episode points to its huge potential and to the need for existing research assumptions in IR (and especially the "Westphalian presumption") to be made subject to re-evaluation.

\section{Religion and Human Agency in the Middle East-A Recovered Level of Analysis in IR}

The level of human nature, as related to political decision-makers, was, inter alia, present in the approach of Hans Morgenthau and other post-War theoreticians in IR. It was also distinguished by K. Waltz in his 1959 work. However, it was abandoned rather rapidly, perhaps because it implied philosophical (and hence also theological!) debate in and around the origins of human nature-a behavioral approach deemed unscientific. Thus, the 1961 article on the subject from Singer makes no mention of this level. A courageous dissident within the behavioral thrust to study turned out to be one its creators-Richard C. Snyder, who proposed a "decision-making" approach (Snyder 1954). While this exerted an influence on the study of foreign policy, and led to a separating-out of Foreign Policy Analysis (FPA), the main current to work on IR continued to reflect it to only a very limited extent (Hudson 2014).

It was only, therefore, in the late 1980s and early 1990s that constructivists came to the conclusion that, by analyzing material factors alone (and not, therefore, reaching into the ideas taking shape in people's minds), it was simply not possible to account for a number of phenomena, let alone predict them. This denoted a return to the "decision-making" approach, and thus to the level of the individual human being, who was treated as a bearer of culture and was worthy of analysis in relation to needs, values, ideas, and preferences. In the view of Valery Hudson, a plus of this approach is the way it brings all the levels of analysis closer together and also integrates IR theory with foreign-policy theories, in this way allowing for a better understanding of international reality (Hudson 2002, pp. 4-17). This can also mean the incorporation of religion into IR.

In the view of Jonathan Fox and Shmuel Sandler, religion may manifest itself in IR in four different ways: As the basis for a view of the world or outlook, a source of identity, a tool legitimizing the rule of political leaders, or a basis for the existence and operation of international or, above all, supranational actors on the world stage (Fox and Sandler 2004, pp. 176-77). The last three of these forms may be made out in international relations as they pertain to the Middle East, with analysis engaged in from the perspectives of the system, state, region, or transnational levels. However, all of these arise out 
of the first-which is to say, the way of thinking or viewing the world that given people manifest and espouse, which allows for the existence of a transcendental sphere and must influence or lead decision-making to a greater or lesser extent. However, to be able to detect the kind of world-views people hold, it is naturally necessary to head for the lowest level of analysis-i.e., the level of the human being that IR has somehow jettisoned.

There would also seem to be no justification for work on the influence of religion at this level to confine itself to political decision-makers or policymakers more widely, which is to say, to the ruling elite (even if a separate matter might be the lack of reliable data). The region of the Middle East has seen major change in the last few decades, in association with the enhanced political participation of "ordinary people", and hence an increase in the influence on international relations they are able to exert. This is linked first and foremost with the now near-universal application of education, as well as the spread of various media. Inhabitants of the Middle East are now far more aware of who rules them and in what way than was the case as the sovereign states in the region were first taking shape. Elections have been held in many of the countries, even if turnouts are seen to depend on a number of different factors and look disparate. Rebellions and protests in and beyond the Arab World—which result in people taking to the streets-point to a higher degree of (at least some kind of) involvement in public life on the part of society.

According to data from the Pew Research Center contained in its 2012 report relating to Muslims around the world, religion is regarded as very important by $89 \%$ of Moroccans, $85 \%$ of Jordanians and Palestinians from the Autonomy, $82 \%$ of Iraqis, $78 \%$ of Tunisians, $75 \%$ of Egyptians, $67 \%$ of Turks, and $59 \%$ of Lebanese followers of Islam. Greater attachment to the religion and its practices (attending the mosque, reading the Koran, and praying several times a day) is declared by more over-35 Muslims than by people aged 18-34. More than 9 out of 10 of those in states surveyed fast during Ramadan, while more than three-quarters practice zakat (Pew Research Center 2012). Gallup research of 2018 further makes it clear that religion is important to $47 \%$ of Israelis, still leaving this country unusual when set against others in the region, and indeed much below the MENA average figure, which was $80 \%$ in the year in question (Gallup Analytics 2019).

Events playing out at the end of 2010 kicked off a debate in the Arab World regarding the political role of Islam. Were Islamist parties up to that time remaining in opposition able to improve people's circumstances when taking the reins of power? Could the founding of religious states ensure that (AHDR 2016, p. 35)? And thus, is Islam a real solution? And, if yes, then what kind of Islam? There is no doubt that the Middle East finds itself in the middle of profound change that is not merely political, but also socio-cultural, and that this may point to the direction that is going to be followed for a number of years. Shadi Hamid thus considers the nature and goal of the contemporary nation-state in the Middle East, and in particular the role that religion in the region has to play. In the view of that author, the region's "exceptionalism" is to lie in its resistance to secularism (Hamid 2017). In such circumstances, the "Westphalian presumption" can simply not be sustained in the longer term.

But is that the real story in the Middle East? IR analysis at the level of the individual requires that we ponder this. And in the last two years, information from two different sources suggests that this area has seen a marked slump in people's trust in religious institutions. According to Gallup research, the share of people in the MENA region seeing religion as important in their lives fell abruptly from 90\% in 2016 to $80 \%$ in 2017. This trend was maintained in 2018 (Gallup Analytics 2019). An Arab Barometer study confirms this trend in the Arab World. Between 2013 and 2019, there was a dramatic fall in the level of confidence in Islamist parties and religious leaders (respectively from $35 \%$ to $20 \%$ and from $51 \%$ to $40 \%$ ). At the same time, the share of those not considering themselves religious rose from $8 \%$ to $13 \%$ (Arab Barometer 2019).

One explanation of this situation may be offered by the spread of new and diverse forms of religiousness, in connection with a change of approach to traditional religious authority-figures and institutions. Half the population of the states making up the Middle East is in fact under 24, while two-thirds of inhabitants there are less than 30 years old. Among these, a clear majority identify 
with religion and see it as playing an important role in their lives (AHDR 2016). But religion is of a changed nature in young societies, even if this need not denote any secularization. For example, the spreading of the word and teachings via media is playing an ever-greater role, while young people also participate en masse in charitable and community activities. Such changes inevitably chip away at the authority of what had previously been the "official" figures in religion, not least as some of these are anyway linked with corrupt elites (Meddeb et al. 2017, pp. 4-5).

Neither the achievement of power by what had hitherto been members of the Islamist opposition (e.g., in Egypt and Tunisia) and the political decisions now being taken by them, nor Daesh's example of restrictive Islam being imposed by means of terror, war, and conquest, would seem to be meeting the expectations of young people, who mostly oppose holistic ideologies, be they nationalist, left-wing, or Islamist (p. 4). What will the new dominant form of religiousness then look like, and how will society in the region look when this new generation take up the reins of power? These are questions for sociologists and political scientists, but also for those doing IR research, who may find many answers to their questions at this level of analysis.

\section{Religion and "Human Security"- How Fruitful for the Future of IR Can the "Mesopotamian Turn" Prove?}

The "Mesopotamian turn" allows IR to take account of the presence and role of religion, which ensure that the Middle East falls outside the "Westphalian presumption", and at the same time undermine any claim to universality on the part of the latter, thereby posing a serious challenge to the entire discipline. The application of multi-level analysis in this case hails back to the 1959 claim from Kenneth Waltz that: "All three images are a part of nature. So fundamental are men, the state, and the state system in any attempt to understand international relations that seldom does an analyst, however wedded to one image, entirely overlook the other two" (Waltz 1959, p. 160). Reflexive modernity would seem to incline the IR researcher to rectify the oversight that involves certain dimensions to international relations being ignored, with the main thrusts to contemporary research now encroached upon by a holistic, multi-level concept that also takes account of the human being. The "Mesopotamian turn" only serves to confirm how this kind of approach conveys the reality under study so much better. Also inherent within it is the potential for action that can assist with the solving of societal problems characteristic of the new millennium. This is then an idea for a new IR identity and a mission for it to pursue in the era of globalization and cultural diversity.

A reflection of the above trend is the human security concept that challenges IR's most important category—security—as associated traditionally with hard power. James K. Wellman stresses that " $(\ldots$ ) scholars and policy-makers are increasingly more willing and able to 'see' not just the instruments of states' power, but also what's on the ground: People struggling to build lives, less interested in national security in the traditional sense than in the simple welfare of their families, tribes, towns, and cities" (Wellman 2013, p. 194).

The concept of human security has, in fact, been under development within the UN system since the 1990s, and is gaining greater and greater scope and recognition for itself (Marczuk 2014). It is founded on the conviction that threats may look different from the point of view of the person, as opposed to the state or the international system. To account for that, the literature often invokes the 1941 "Four Freedoms" concept after President Franklin D. Roosevelt. In line with that, everyone "everywhere in the world" should enjoy (and have guaranteed) freedom of speech, freedom of religion, freedom from fear, and freedom from want. Thus, the international system arising after World War II under UN leadership was not merely to keep the peace, but also to make sure that effect was given to the said freedoms, with the reflection of this being UN activity in the name of both the protection of human rights and global socioeconomic development and progress.

Roosevelt's concept, in fact, had its origin in America's social gospel movement (led by Walter Rauschenbusch)—which also inspired President Woodrow Wilson, who, inter alia, postulated the establishment of the League of Nations (Wellman 2013, p. 195). However, this actually religious 
provenance was forgotten about in the Cold War era, with what mattered in inter-state relations then being hard power. That left the adopted concept for development founded firmly upon economic growth as the answer to all of the needs of state and society alike.

Notwithstanding a developed system of human-rights protection, the level of analysis relating to the individual human being had actually been forgotten about-this way of seeing things would only, in fact, begin to change once more in the 1990s. The failures characterizing successive UN "decades of development" combined with changes to the world order to ensure that development studies began to be re-evaluated. Evidence of that came with the first (1990) Human Development Report, which showed that the goal of all efforts made to achieve further development should in fact be the human being. However, while it focused in on seven material dimensions to development, the Report saw no need for religion to be referred to.

It was a later report on human development (1994) that gave rise to the concept of human security, as based on convictions regarding the integrated nature of two of the freedom dimensions, i.e., freedom from fear and freedom from want (Marczuk 2014, p. 41). The Commission on Human Security established several years later came out with a 2003 report, in which we read: "Human security means protecting fundamental freedoms-freedoms that are the essence of life. It means protecting people from critical (severe) and pervasive (widespread) threats and situations. It means using processes that build on people's strengths and aspirations. It means creating political, social, environmental, economic, military, and cultural systems that together give people the building blocks of survival, livelihood, and dignity" (Commission on Human Security 2003, p. 4).

Let us then note that this kind of understanding of human security as a safeguarding of freedoms that constitute the "essence of life" for people, and as a reference to their "strengths and aspirations", leads to an IR incorporating the previously abandoned level of analysis relating to the individual human being. It also opens a double gate to the inclusion of religion. On the one hand, this occurs via a return to Roosevelt's "Four Freedoms" (given that one of the fundamental freedoms guaranteeing the "essence of life" is freedom of religion), while, on the other, there is the emphasis on "creating cultural systems" that secure dignity, whose basis in practice through most of the non-Western world tends to be religion. We can also see that the human security idea comes into contact with the "Mesopotamian turn" and allows IR to incorporate the religion present at every level of IR analysis in the Middle East.

So what can the IR researcher learn from the "Mesopotamian turn", i.e., the inclusion within his/her research of study in the Middle East region? While the Arab Human Development Report of 2009 (entirely devoted to human security) offers only marginal treatment of religion, the latter may not be ignored, as the above considerations make clear. Precise analysis of the needs and expectations of people in the Middle East compels us to account for the role of religion as we consider international relations. Notwithstanding the changes religiousness in this region has been undergoing (be this individualization, post-Islamism, the return of traditional forms, or the so-called "radicalization" - in a reactionary direction), this is and will remain longer-term one of the most important aspects to relations pertaining in the region. This fact is noted by a further report devoted to Arab young people in the wake of the Arab Spring events (2016). In some sense now rectifying earlier mistakes, this report regards religion as a crucial point of reference see (AHDR 2016, pp. 34-35).

Religion, and especially an Islam undergoing change, offers a basis for the emancipation of people that have been marginalized in the international relations, i.e., all those participating in the Westphalian system while never having played any part in developing its principles. Through analysis of religion's presence in international relations in the Middle East, researchers are in a position to re-evaluate-and presumably downplay-the Westphalian synthesis and presumption. In turn, the UN system's development of the concept of human security leaves space for the breaking of "the rule of secularism" in IR, with the discipline thus being offered a chance to head back to social reality.

At the end, it is worth returning to the initial idea and following the maxim of Spanish philosopher José Ortega y Gasset, who once noted that the lives lived out tomorrow in the squares and the streets will depend on the thinking going on today in the universities. Thus, engagement in academic reflection 
as to the role of religion in the lives of individuals, groups, and states is important not only in the way it offers a better understanding of the world around us and the development of IR, but also in line with the major role that can be played in the evolution of today's social order at all levels, up to and including the international. The Middle East offers proof of the fact that ongoing pursuit of research in this direction is a must.

Funding: This research received no external funding.

Conflicts of Interest: The author declares no conflict of interest.

\section{References}

Aarts, Paul. 1999. The Middle East: A Region without Regionalism or the End of Exceptionalism? Third World Quarterly 20: 911-25. [CrossRef]

Adler, Emanuel. 1997. Imagined (Security) Communities: Cognitive Regions in International Relations. Millennium. Journal of International Studies 26: 249-77. [CrossRef]

Arab Human Development Report (AHDR). 2004. Toward Freedom in the Arab World. Available online: http://hdr.undp.org/en/content/arab-human-development-report-2004 (accessed on 24 January 2020).

Arab Human Development Reports (AHDR). 2016. Youth and the Prospects for Human Development in a Changing Realities. Available online: https:/www.undp.org/content/dam/rbas/report/AHDR\%20Reports/ AHDR\%202016/AHDR\%20Final\%202016/AHDR2016En.pdf (accessed on 24 January 2020).

Akyol, Mustafa. 2019. A New Secularism Is Appearing in Islam. Available online: https://www.nytimes.com/ 2019/12/23/opinion/islam-religion.html (accessed on 28 December 2019).

Appleby, R. Scott. 2000. The Ambivalence of the Sacred: Religion, Violence, and Reconciliation. Lanham-Boulder, New York and Oxford: Rowman \& Littlefield.

Arab Barometer. 2019. Arabs Are Losing Faith in Religious Parties and Leaders. Available online: https: //www.arabbarometer.org/2019/12/arabs-are-losing-faith-in-religious-parties-and-leaders/ (accessed on 25 January 2020).

Bauman, Zygmunt. 2004. Ponowoczesność. In Słownik Społeczny. Edited by Bogdan Szlachta. Kraków: Wydawnictwo WAM.

Berger, Maurits. 2010. Religion and Islam in Contemporary International Relations. Clingendael Diplomacy Papers no. 27. Available online: https://www.clingendael.org/sites/default/files/pdfs/20100400_cdsp_book_ mberger.pdf (accessed on 25 December 2019).

Bishop of Truro's Independent Review for the Foreign Secretary of FCO Support for Persecuted Christians. Final Report and Recommendations 2019. Available online: https://christianpersecutionreview.org.uk/storage/ 2019/07/final-report-and-recommendations.pdf (accessed on 15 January 2020).

Blum, Ruthie. 2019. Israel, Iran and Trump: Behind the Rhetoric. Available online: https://www.algemeiner.com/ 2019/08/28/israel-iran-and-trump-behind-the-rhetoric/ (accessed on 15 January 2020).

Bronk, Andrzej. 2009. Podstawy nauk o religii. Lublin: Towarzystwo Naukowe KUL.

Bull, Hedley. 1984. The Revolt against the West. In The Expansion of International Society. Edited by Hedley Bull and Adam Watson. Oxford: Oxford University Press.

Buzan, Barry, and Richard Little. 2001. Why International Relations has failed as an intellectual project and what to do about it. Millennium: Journal of International Studies 30: 19-39. [CrossRef]

Christian Persecutions. 2020. Available online: https://www.opendoorsusa.org/christian-persecution/ (accessed on 20 January 2020).

Commission on Human Security. 2003. Human Security Now. Available online: https://reliefweb.int/sites/ reliefweb.int/files/resources/91BAEEDBA50C6907C1256D19006A9353-chs-security-may03.pdf (accessed on 15 January 2020).

Coskun, Bezer Balamin. 2005. Region and Region Building in the Middle East. Problems and Prospects. UNU-CRIS Occasional Papers 0-2005/22. Available online: http://cris.unu.edu/region-and-region-building-middle-eastproblems-and-prospects-0 (accessed on 15 January 2020).

Council of the European Union. 2013. Guidelines on the Promotion and Protection of Freedom of Religion or Belief. Available online: https://www.consilium.europa.eu/uedocs/cms_data/docs/pressdata/EN/foraff/137585.pdf (accessed on 15 November 2019). 
Dzisiów, Aleksandra. 2006. Dialog Cywilizacji Mohammada Chatamiego jako współczesny model stosunków międzynarodowych-alternatywa dla "Zderzenia cywilizacji” Samuela Huntingtona. Available online: http://www.psz.pl/168-archiwum/aleksandra-dzisiow-dialog-cywilizacji (accessed on 15 December 2019).

Eisenstadt, Shmuel. N. 2000. The Reconstructing of Religious Arenas in the Framework of 'Multiple Modernities'. Millennium: Journal of International Studies 29: 591-611. [CrossRef]

Fox, Jonathan, and Shmuel Sandler. 2004. Bringing religion into International Relations. New York: Palgrave Macmillan.

Gallup Analytics. 2019. Available online: http://library.osu.edu (accessed on 20 January 2020).

Gieryńska, Agnieszka. 2017. Organizacja Wspótpracy Islamskiej. Geneza, charakterystyka i działalność w regionie Bliskiego Wschodu. Warszawa: Wydawnictwo Scholar.

Hamid, Shadi. 2017. Islamic Exceptionalism. How the Struggle over Islam Is Reshaping the World. New York: St. Martin's Press.

Hanafi, Sari. 2012. The Arab Revolution: The Emergence of a New Political Subjectivity. Contemporary Arab Affairs 5: 198-213. [CrossRef]

Hinnebusch, Raymond, and Anoushiravan Ehteshami, eds. 2014. The Foreign Policies of Middle East States, 2nd ed. Boulder and London: Lynne Rienner Publishers.

Hudson, Valery M. 2002. Foreign Policy Decision-Making: A Touchstone for International Relations Theory in the Twenty-First Century. In Foreign Policy Decision-Making (Revised). Edited by Richard C. Snyder and H. W. Bruck Burton. Sapin and New York: Palgrave Macmillan, pp. 1-20.

Hudson, Velery M. 2014. Foreign Policy Analysis. Classic and Contemporary Theory, 2nd ed. Lanham: Rowman \& Littlefield.

Jones, Clive. 2002. The Foreign Policy of Israel. In The Foreign Policies of Middle East States. Edited by Raymond Hinnebusch and Anoushiravan Ehteshami. London: Lynne Rienner Publishers, pp. 115-40.

Keohane, Robert O. 2002. The globalization of informal violence, theories of world politics, and the "liberalism of fear". In Power and Governance in a Partially Globalized World. London and New York: Routledge, pp. $272-87$.

Kepel, Gilles. 2003. Święta wojna. Ekspansja i upadek fundamentalizmu muzułmańskiego. Warszawa: Wydawnictwo Akademickie Dialog.

Kepel, Gilles. 2010. Zemsta Boga. Religijna rekonkwista świata. Warszawa: Wydawnictwo Krytyki Politycznej.

Korany, Bohgat, and Ali E. Hillal Dessouki, eds. 2010. The Foreign Policies of Arab States. The Challenge of Globalization. Cairo and New York: The American University in Cairo Press.

Kostecki, Wojciech. 2013. Poziomy analizy polityki zagranicznej. In Poziomy analizy stosunków międzynarodowych. Edited by Edward Haliżak and Marek Pietraś. Warszawa: Wydawnictwo Rambler, pp. 40-53.

Kulska, Joanna. 2013. 'Ambiwalencja świętości' jako przejaw czynnika religijnego w stosunkach międzynarodowych. Stosunki międzynarodowe - International Relations 2: 85-100.

Lee, Robert D. 1997. Overcoming Tradition and Modernity: The Search for Islamic Authenticity. Boulder: Westview Press.

Lee, Robert D. 2010. Religion and Politics in the Middle East. Identity, Ideology, Institutions, and Attitudes. Boulder: Westview Press.

Łoś-Nowak, Teresa. 2013. Państwowy poziom analizy w stosunkach międzynarodowych. In Poziomy analizy stosunków międzynarodowych. Edited by Edward Haliżak and Marek Pietraś. Warszawa: Wydawnictwo Rambler, pp. 15-37.

Marczuk, Karina. 2014. Pojęcie i zakres human security. In Trzy wymiary wspótczesnego bezpieczeństwa. Edited by Stanisław Sulowski and Michał Brzeziński. Warszawa: Dom Wydawniczy Elipsa, pp. 40-49.

Meddeb, Hamza, Silvia Colombo, Katerina Dalacoura, Lorenzo Kamel, and Olivier Roy. 2017. Religion and Politics. Religious Diversity, Political Fragmentation, and Geopolitical Tension. MENARA Working paper, nr 7. Available online: https://www.cidob.org/en/publications/publication_series/menara_papers/working_ papers/religion_and_politics_religious_diversity_political_fragmentation_and_geopolitical_tensions_in_ the_mena_region (accessed on 24 February 2020).

Ochsenwald, William. 1981. Saudi Arabia and the Islamic Revival. International Journal of Middle East Studies 13: 271-86. [CrossRef]

Pew Research Center. 2012. The World's Muslim: Unity and Diverse. Available online: https://www.pewforum. org/2012/08/09/the-worlds-muslims-unity-and-diversity-executive-summary (accessed on 21 January 2020). 
Pew Research Center. 2018. Global Uptick in Government Restrictions on Religion in 2016. Available online: https: //www.pewforum.org/2018/06/21/global-uptick-in-government-restrictions-on-religion-in-2016 (accessed on 21 January 2020).

Philpott, Daniel. 2002. The Challenge of September 11 to Secularism in International Relations. World Politics 55: 66-95. [CrossRef]

Philpott, Daniel, and Timothy Samuel Shah. 2011. The Dangers of Secularism in the Middle East. Available online: https://www.belfercenter.org/publication/dangers-secularism-middle-east (accessed on 30 January 2020).

Sandler, Shmuel. 2018. The Jewish Origins of Israeli Foreign Policy. A Study in Tradition and Survival. London and New York: Routledge.

Schreiber, Hanna. 2012. Religia jako element "zwrotu kulturowego" w stosunkach międzynarodowych. In Religia w stosunkach międzynarodowych. Edited by Anna M. Solarz and Hanna Schreiber. Warszawa: Wydawnictwa UW, pp. 51-76.

Segesvary, Victor. 2000. Dialogue of Civilizations: An Introduction to Civilizational Analysis. Lanham, New York and Oxford: University Press of America.

Shakman Hurd, Elizabeth. 2008. The Politics of Secularism in International Relations. Princeton and Oxford: Princeton University Press.

Singer, J. David. 1961. The Levels-of-Analysis Problem in International Relations. World Politics 14: 77-92. [CrossRef]

Snyder, Richard C. 1954. Decision-Making as an Approach to the Study of International Politics. Princeton: Princeton University.

Solarz, Anna. 2007. Prawa człowieka i etyka w stosunkach międzynarodowych. Polski Przegląd Dyplomatyczny 1: 63-89.

Solarz, Anna M. 2014. The Role of Religious and Secular Factors in the Development of the Science of International Relations in Israel. In Re-Visions and Re-Orientations. Non-European Thougth in the International Relations Studies. Edited by Jakub Zajączkowski, Marcin Florian Gawrycki and Agnieszka Bógdal-Brzezińska. London, New Delhi, New York and Sydney: Bloomsbury, pp. 87-111.

Solarz, Anna M. 2018. The Religious Factor in Contemporary World Politics-Analytical Frameworks. In New Geographies of the Globalized World. Edited by Marcin Wojciech Solarz. London and New York: Routledge, pp. 115-43.

Solarz, Anna M., and Marta Woźniak Bobińska. 2018. Studia nad polityką zagraniczną muzułmańskich państw Bliskiego Wschodu. In Wrowadzenie do polityki zagranicznej muzutmańskich państw Bliskiego Wschodu i Afryki Pótnocnej. Edited by Marta Woźniak-Bobińska and Anna M. Solarz. Warszawa: Wydawnictwo Scholar, pp. 11-27.

Tabak, Hüsrev. 2017. Manifestations of Islam in Turkey's Foreign Policy: Islamic Internationalism and Turkish Islam. The Copernicus Journal of Political Studies 1: 5-23. Available online: https:/apcz.umk.pl/czasopisma/ index.php/CJPS/article/view/CJPS.2017.001 (accessed on 28 January 2019).

Telhami, Shibley, and Michael Barnett, eds. 2002. Identity and Foreign Policy in the Middle East. Ithaca and London: Cornell University Press.

Thomas, Scott M. 2003. Taking Religious and Cultural Pluralism Seriously. In Religion in International Relations. The Return from Exile. Edited by Fabio Petito and Pavlos Hatzopoulos. New York: Palgrave Macmillan, pp. 21-53.

UNHCR. 2020. Egypt: The International Islamic Relief Organization (IIRO) and Whether It Is Involved in Funding Terrorist Activities. Available online: https://www.refworld.org/docid/3f7d4d901c.html (accessed on 25 February 2020).

Valbjørn, Morten. 2004. Toward a "Mesopotamian Turn": Disciplinarity and the Study of the International Relations of the Middle East. Journal of Mediterranean Studies 14: 47-75.

Waltz, Kennetz N. 1959. Man, the State and War. A Theoretical Analysis. New York and London: Columbia University Press.

Wejkszner, Artur. 2016. Państwo Islamskie, Narodziny Nowego Kalifatu? Warszawa: Difin.

Wellman, James K., Jr. 2013. Human security: A secularized social gospel and the rediscovery of religion. In The Routledge Handbook of Religion and Security. Edited by Chris Seiple, Dennis R. Hoover and Pauletta Otis. London and New York: Routledge, pp. 193-203.

Wolff, Sarah. 2018. UE religious engagement in the Southern Mediterranean: Much ado about nothing? Mediterranean Politics 23: 161-81. [CrossRef] 
Zajączkowski, Jakub. 2013. Poziomy analizy regionalnej w nauce o stosunkach międzynarodowych. In Poziomy analizy stosunków międzynarodowych. Edited by Edward Haliżak and Marek Pietraś. Warszawa: Wydawnictwo Rambler, vol. 1, pp. 55-78.

Zdanowski, Jerzy. 2009. Wspótczesna muzutmańska myśl społeczno-polityczna. Nurt Braci Muzułmanów. Warszawa: Wydawnictwo Naukowe ASKON Sp.zo.o.

Zdanowski, Jerzy. 2013. Historia społeczeństw muzułmańskiego Bliskiego Wschodu w XX w. Warszawa: Wydawnictwo Naukowe ASKON Sp.zo.o.

Zdanowski, Jerzy. 2014. Państwo na muzułmańskim Bliskim Wschodzie, Procesy genezy i czynniki trwania. Kraków: Krakowskie Towarzystwo Edukacyjne sp. z o.o. - Oficyna Wydawnicza AFM.

(C) 2020 by the author. Licensee MDPI, Basel, Switzerland. This article is an open access article distributed under the terms and conditions of the Creative Commons Attribution (CC BY) license (http://creativecommons.org/licenses/by/4.0/). 
Article

\title{
Fragmentation and Cooperation in the Jihadi International (Sub)System: 'Islamic State' vs. Al-Qaeda and Beyond
}

\author{
Marina Eleftheriadou \\ Department of Political Science and International Relations, University of Peloponnese, GR-20132 Corinth, \\ Greece; m.elef@cemmis.edu.gr
}

Received: 27 February 2020; Accepted: 31 March 2020; Published: 3 April 2020

\begin{abstract}
The article explores the implications the rise of the 'Islamic State' (IS) had on the international order and the salafi-jihadi movement. The main argument is that at the height of its activity (2014-2016) IS was a de facto revolutionary state. In this capacity, IS challenged the international order because contrary to revolutionary states in the past it negated the foundations of the Westphalian system. At the same time, the rise of IS had a tremendous impact on the jihadi (sub)system, as it initiated a period of fragmentation and alliance-building. The competition between IS and al-Qaeda for the hegemony of the movement did not revolve around direct fighting as much as efforts to outbid the rival group. One of the main conduits of this competition was the 'war of bay'as (pledges of allegiance)', which consisted of competitive oaths of allegiance from local jihadi forces to one of the two groups. In local contexts, the 'war of bay'as' increased tensions and factionalism within jihadi groups, as splinter groups decided to side with the new revolutionary foco. The fragmentation of local jihadi groups unfolded along pre-existing cleavages, grievances and resource-related motivations, increasing the levels of violence and complexity in these local conflicts.
\end{abstract}

Keywords: 'Islamic State'; al-Qaeda; alliances; competition; fragmentation; international order; revolutionary state

\section{Introduction}

In July 2014, the entire world watched in shock and disbelief Abu Bakr al-Baghdadi declare the restoration of the 'Caliphate'. Today, al-Baghdadi is dead, and the Caliphate has been reduced to a (imaginary) shell. However, despite its current status, the 'Islamic State' (IS) merits a deeper exploration, for its impact and repercussions have been profound and far-reaching. IS's violent entrance in the global scene has shuttered much of our understanding of violent non-state actors and the salafi-jihadi movement in particular. For years the common wisdom was that the jihadi movement (and particularly al-Qaeda) had undergone an organizational transformation in the wake of the 'war on terrorism', evolving from a relatively hierarchical group to a deterritorialized network that preferred attacking the West than controlling territory. Yet, in mid-2014, IS demonstrated that jihadi groups do not mind controlling territory, if given the opportunity.

However, IS's impact has been larger than simply invalidating the main premise of the 'new wars' paradigm. As this article shows, the declaration of the Caliphate and the extent of IS's territorial control raise important questions in the study of international politics. Was IS, at the height of its activity in 2014-2016, a terrorist group, a guerrilla movement or a revolutionary state? The answer to this question will help us understand the nature of IS's challenge to the global order. If IS (and possible future copycats) are able to socialize into the international system's norms, as other revolutionary states in the past did, then the international community might consider a more conciliatory response. On the contrary, if IS's ideology and strategic considerations preclude this type of groups to become 
'normal' members of the international community, conciliatory gestures will have a limited impact, no matter how generous they are.

The meteoric rise of IS did not rattle only the international system, but it had a profound impact on the salafi-jihadi movement as well. The salafi-jihadi (sub)system, as the article shows, underwent an intense period of competition and alliance-building. This competition primarily involved IS and al-Qaeda, which competed for hegemony in the jihadi movement. Drawing on Watts's (2016) distinction between 'destructive' and 'escalating competition', the article explores the phases of IS-al-Qaeda rivalry. However, contrary to Watts, the article posits that destructive competition, in terms of direct conflict between al-Qaeda and ISIS has been in reality limited, even where they have been the closest, Syria. Instead, as the article shows, the rivalry has been played out in three domains: propaganda, attacks on western targets and a 'war of bay'as', which is the main focus of this article. Prominent ideologues and jihadi groups around the world were called to take a stance on the al-Qaeda-IS conflict. Many felt the need to situate themselves on the new jihadi map, either reiterating their loyalty to al-Qaeda or siding with the new-comer. This resulted in a flurry of competitive pledges of oath coming from all the corners of the jihadi movement. This war of bay'as has ushered a period of turmoil in the jihadi subsystem. The process of system recalibration took the form of international alliance-building and local fragmentation, which affected most local jihadi scenes and conflicts.

The article explores the challenge IS posed to the international system and the jihadi subsystem as follows. The first section provides a brief theoretical discussion of fragmentation and alliance-building in violent non-state groups. The theoretical propositions discussed in this section are then used to inform the examination of IS and its competition with al-Qaeda. The exploration of IS's challenge is expounded in three parts. The first of the three examines the nature of IS's challenge to the international order by asking what type of actor IS (or the Caliphate) was at the height of its activity, what was its stance towards the international system, and conversely, what was the stance of the international community towards IS. The second part explores the repercussions of IS's claim to hegemony within the jihadi movement by tracing the roots and mechanisms of al-Qaeda-IS competition and identifying the main conduits of intra-jihadi rivalry at the highest level. The last part opens the focus to include IS-inspired intra-movement competition and fragmentation at the local level, highlighting the motivations behind (splinter) groups' decision to pledge allegiance (bay'a) to Abu Bakr al-Baghdadi.

\section{Friends or Foes? Alliance-Building and Fragmentation in Non-State Armed Groups}

Militant groups ally and feud like every other political actor. Of the two, intra-group competition and factionalism is easier to pinpoint. Internal fragmentation or 'fratricide' (Hafez 2017; Staniland 2012) occurs when groups that belong to the same movement 'start targeting each other through words and/or actions' (Hamming 2020, p. 14). Competition between groups has been linked to higher lethality, as the effort to 'outbid' rival groups leads to more violence (Bakke et al. 2012; Conrad and Greene 2015) and suicide terrorism (Bloom 2005), especially in religious and nationalist movements (Nemeth 2014).

Alliances, on the other hand, are harder to define because not all alliances are equal. The most concise definition of alliances draws from the International Relations (IR) theory and defines alliances as 'formal or informal collaborative arrangements between two or more actors who employ terrorist tactics in the pursuit of joint interests' (Moghadam 2017, p. 7). In reality, cooperation might take various forms: ideological, logistical and operational (Jadoon 2018; Karmon 2005; Phillips 2019). In the context of the IS-al-Qaeda rivalry, ideological cooperation might take the form of a public pledge of allegiance. Logistical cooperation involves sharing material and/or non-material resources, such as weapons, funds, training, consultations and propaganda assistance. Operational cooperation refers to cooperation in the preparation or execution of attacks.

Groups might forge collaborative arrangements in one or more fields. The more cross-sectional and intensive the cooperation the deeper the alliance. Alliances can take four (ideal) forms: mergers, strategic alliances, tactical cooperation, and transactional cooperation (Jadoon 2018; Moghadam 2015). At the lower end of cooperation, groups enter into a marriage of convenience to fulfil short-term 
and narrow goals. Limited in nature and scope, this cooperation is driven by practical rather than ideological goals. High-end cooperation, on the other hand, involves cooperation in more than one domain. These alliances, which range from strategic alliances to mergers and full absorption of the weaker group, constitute the highest form of alliance building between militant groups.

The scholarship on alliance-formation between violent non-state groups agrees on one point: alliances are rare (Asal et al. 2016, pp. 6-7; Byman 2014, p. 438; Oots 1989, p. 144). If anything, fragmentation is the norm. The rarity of alliances 'does not make them uninteresting' (Oots 1989, p. 145), though. Alliances have been associated with higher lethality (Asal and Rethemeyer 2008; Oots 1989), the adoption of suicide bombing tactics (Asal et al. 2016) and the prospect of pursuing CBRN weapons (Asal et al. 2012). Given their rarity but high impact, there are two overriding questions: what makes non-state alliances so hard in the first place and what motivations make groups overcome these obstacles and forge alliances against 'common sense'. Answers to these questions can be grouped under two broad categories. The first group includes studies that rest on material consideration and organizational imperatives to explain alliances (and fragmentation) in armed non-state groups. The second category contains studies that, to a varying extent, acknowledge the importance of power considerations but, at the same time, place more emphasis on ideology and shared framing in the formation and deepening of alliances.

The study of alliance formation in non-state conflicts has built on various theoretical traditions. The most daring drew from IR theory and particularly balance of power or balance of threat theories. Karmon (2005), for instance, has demonstrated the relevance of neorealist concepts and balance-of-threat alliance-building theories in the study of terrorist groups' (international) cooperation. In the same vein, Christia (2012) has demonstrated the centrality of power considerations in civil war alliances, in tandem with realist expectations as the author admits. Indeed, as some scholars have noted, non-state groups often face similar conditions of anarchy as states in the international system (Adamson 2005, pp. 43-44; Christia 2012, p. 51; Fearon 1995; Posen 1993). The lack of institutions to mitigate uncertainty and suspicion attenuates commitment issues in non-state alliance formation (Bacon 2014, p. 5; Christia 2012, p. 6). The inability of non-state groups to enforce commitment, due to the nature of their operations, renders power considerations central to their outcome. Although state sponsors can on occasions act as external enforcers, increasing overall trust and predictability (Bapat and Bond 2012), in general, the lower the degree of institutionalization within movements, the higher the possibility of fragmentation and infighting if there are changes in the distribution of power (Bakke et al. 2012).

Organizational issues and concerns have been the focus of numerous studies which, instead of IR theory, draw insights from businesses cooperation or organizational theory (Bacon 2018; Byman 2014; Horowitz and Potter 2014). Along the lines of realist-inspired literature, these studies downplay ideology in favor of resources-related considerations. Militant groups align to procure tangible and intangible resources to increase their overall capabilities. By forming alliances, groups might expect direct assistance in the form of funds and weapon transfers or training opportunities, especially if the ally holds territory. Groups with transnational aspirations might seek alliances to gain access to local resources, people and local terrain's knowledge (Byman 2014, p. 431; Jadoon 2018, p. 31). Intangible resources, on the other hand, might take the form of 'best practices' sharing (Cragin et al. 2007), as groups might benefit from the transfer of new information, technology and tactics (Asal et al. 2016; Horowitz 2010). Some groups might also want to associate themselves with an established group to improve their credibility, legitimacy and prestige or to exploit the opportunity to 're-invent their image' (Bacon 2014, pp. 4, 8). This is most evident in groups with acute organizational learning or adaptation needs that for various reasons cannot undertake self-reform to address their problems (Bacon 2014, p. 16). The notion of weakness as a driver for alliance-building is contested (Phillips 2019). Some studies consider (effective) state counterinsurgency and military losses as an important motivation for groups to seek allies (Kalyvas and Kocher 2007). Well-placed allies can offer the struggling group territory and networks to weather the storm. Al-Qaeda's reliance on Taliban's safe houses and trusted networks after US intervention in Afghanistan is a case in point (Bacon 2014, p. 8). On the contrary, 
Bapat and Bond (2012) claim that weak groups might seek alliances but their inability to withstand counterterrorism pressure turns them into undesirable partners.

In this turmoil of competing arguments, ideology-based studies pose a simple counter-argument: groups ally (or fragment) for ideological reasons. Drawing from scholarship on state alliances (Barnett 1996; Holsti et al. 1973), these studies posit that a shared enemy and shared ideology affect partner selection (Asal et al. 2016; Gade et al. 2019). Given that groups operate in an anarchic and unpredictable environment, ideological homophily might improve the levels of trust among groups and institute commonly accepted norms and preferences. Agreement on the basics, such as conflict framing, conception of the ideal polity, and territorial aspirations (Gade et al. 2019), might smoothen the path to alignment.

Walt (1987) has demonstrated that some ideologies are extremely divisive to allow alliance formation. Therefore, ideology is most likely to play an important role in alliance formation when this ideology is unifying, not divisive. Drawing from Walt, Karmon (2005) identifies nationalistic ideologies as the least accommodating to inter-group cooperation and anarcho-communist ideologies as the most prone to forge alliances. Nationalistic ideologies are by nature exclusionary and territorially bounded, characteristics that diminish the attractiveness of alliances. On the opposite side, the main characteristic that encouraged the formation of coalitions between groups that ascribed to anarcho-communism was their fluid and decentralized ideological base (Karmon 2005, p. 42). Religious ideologies, which Karmon touches only briefly, can offer similar encompassing and decentralized ideological bases. Indeed, relevant research has shown that groups that share religious affiliation are particularly likely to form alliances (Asal et al. 2016; Phillips 2019).

The article sustains that the main difference of religious ideologies is that the latter can be divisive locally but unifying globally. Religious groups often adopt exclusionary views towards competitive forces in their immediate circle of operations. The inherent centralization imperative in religious ideologies, such as salafi-jihadism, and competition over local resources and recruits fuel intra-field rivalries and fragmentation. At the same time, religious groups often ascribe to a transnational and transcendental understanding of community. Therefore, they aspire to speak in the name of a global community of faithful that recognizes no borders. Often lacking the capacity to reach these global communities, religious groups choose to forge alliances with local same-minded forces. International alliances of this kind are possible because the two parties do not 'compete in the same primary political and resource market' (Bacon 2014) and they have fewer things to worry about.

\section{The 'Islamic State' against the World}

\subsection{The 'Caliphate' Enters the Westphalian Order}

Every study of IS and its self-proclaimed 'Caliphate' inevitably stumbles upon the fundamental question of how best approach the 'Islamic State' entity and the global jihadi movement in general. IS has global interests and nearly global reach, to a degree that few militant organizations had in the past, including al-Qaeda. Contrary to al-Qaeda, though, IS has 'presented' the international community with its version of being a state. In this capacity, IS has operated simultaneously in two systems: the international—Westphalian—system and the jihadi (sub)system. From mid-2014 until 2016, IS controlled more than 100,000 square kilometers of territory and a population of over 11 million people (Jones et al. 2017), which were governed through sophisticated administrative structures. In this regard, it was larger, more populous and better-governed than many contemporary states. This raised the question if we should continue treating IS as a terrorist organization or the concept of a (revolutionary) state is more appropriate (Rich 2016; Walt 2015) and if that is the case what should be the stance of the international community.

Previous research on revolutionary states has shown that revolutionary states have a deep impact on the international system, either by increasing the possibility of international conflict (Maoz 1996; Walt 1996) or by challenging and occasionally changing the norms and logic of the 
established international order (Armstrong 1993; Halliday 1999). The aim of revolutionary groups is not only to seize power, but to radically change also the socio-political relations and the society. This aim is not restricted to the domestic front. It involves the international society as well. By the same token, revolutionary regimes perceive the international order under a Manichean prism; a struggle between the forces of 'good and evil, rich and poor, oppressed and oppressors, old and new' (Armstrong 1993, p. 197). Often guided by a teleological view of world politics, they do not consider themselves bound by the established rules, putting forward instead notions of 'universal society' and world revolution (Halliday 1999). Hence, an inherent feature of revolutionary states is their aspiration to export their revolution, either through conquest or by providing an inspirational example for others to copy (Walt 2015). This aspiration is equally guided by their ideological convictions and the need to strengthen the regime internally by finding scapegoats for their troubles (Maoz 1996).

These dynamics are readily evident in the 'Islamic State'. The basic tenet of IS's conceptualization of territoriality rests on the conviction that the 'rebirth of the ummah and the caliphate ... require deterritorializing and dismantling the colonial geopolitical heritage and its national borders and nation states and reterritorializing the ummah and caliphate' (Jabareen 2015, p. 53). Indeed, IS has, on several occasions, rejected any obstacle (be it nationalism or factionalism) that stands in the way of a united ummah (Dabiq 2015d, pp. 3-6). As al-Baghdadi stated in 2012: 'the Islamic State does not recognize synthetic borders, nor any citizenship besides Islam' (Bunzel 2015, p. 24). In other words, IS believes that no aspects of territorial sovereignty, such as 'borders... passports or visas' (Dabiq 2014, p. 23) might limit its global claims to 'Makkah and al-Madīnah ... Baytul-Maqdis and Rome' (Dabiq 2014, p. 3). Therefore, it does not see itself as part of and does not have any 'commitments towards the international community' (Al-Shishani 2014). In this light, all states but the Islamic State are considered illegitimate.

Nevertheless, the ideological fervor of revolutionary states and their effort to change the international order is reciprocated by intense structural pressures to 'socialize' in the same norms and logic they abhor (Armstrong 1993; Walt 1992). In order to secure their survival and protect themselves from internal and external counter-revolution forces, they need to engage in international trade and find allies. At the same time, the fact that they have to run a state ironically forces them to resort and legitimize the international norms and tools that safeguard sovereignty and by extent the international order (Armstrong 1993, p. 302). Indeed, when IS state-project came under western military attack in 2014, IS appeared to contemplate some type of socialization within the international system's norms. The conditions of this socialization are outlined in a series of articles, authored by the captured journalist John Cantlie (Dabiq 2015a, pp. 48-50; 2015d, pp. 64-67). Exploring the conditions for a respite in IS's war against the western countries, Cantlie draws on previous examples of revolutionary states, such as Bolshevik Russia and Maoist China, but stops short of foregoing IS's aspirations of global revolution. The editorial note on one of Cantlie's articles clearly states that IS could offer the West nothing more than a temporary truce (Dabiq 2015d, p. 67). Its ideological rigidity, notwithstanding, the IS has an additional characteristic that renders its socialization in the international system more problematic. Contrary to other revolutionary states, it was not established within the borders of an existing state, but from the start it was a transnational project that covered parts of both Iraq and Syria, without though overthrowing either of the ruling regimes.

Given the revolutionary logic and the formative conditions of IS, the question that remains is whether the international order will choose to accommodate such as state or find ways to destroy it. Vu and Van Orden (2019) employ a three-pronged test to examine IS's 'suitability' for incorporation in the international order: power capabilities, shared values and self-destructive tendencies. They claim that, first, IS was not powerful enough and did not have a powerful patron to 'force' the international community to accept the reality of its existence. Second, ISIS shared no values whatsoever with Western societies. Hence, there was no common ground that could ease IS into the international order with the prospect of future moderation, as happened for example in the case of Iran. Third, IS's extremism was 
inherently self-destructive as it alienates possible allies and the local population. Hence, as the authors predicted IS was doomed to self-destroy.

IS's extremism and inherent contradictions lied at the heart of discussions around the stance the international community should assume vis-à-vis the IS and the best possible strategy for dismantling its state. One approach was containment. The idea behind this strategy was that IS's ideology was too parochial to inspire a revolutionary wave and in any case it was not as powerful as many feared to warrant a military intervention, which could inadvertently strengthen the resolve of its supporters and boost its prestige (Walt 2015, p. 42). At the same time, though, its existence was too damaging to simply be left alone, as is the case for other de facto states, such as Somaliland. Instead, IS was bound to fail because its economy and its state model was unsustainable in the long run. Hence, the best strategy was to contain and isolate it, while applying subtle pressure through local and regional forces to heighten its contradictions and accelerate its demise. Clint Watts (2015) proposed a similar approach, which he dubbed a 'let them rot' strategy. Drawing from the experience of Algerian forces in dismantling the enclaves of the Groupe Islamique Armé (GIA) during the Algerian civil war, he claimed that by actively preventing the formation of these jihadist states, one allows the preservation of Sharia governance dream. Instead, if we allow them to form, the proponents of such a state will see that after all it is not the utopia they dreamed.

Both scholars, however, highlighted some requirements for this strategy to work, which were absent or were difficult to implement in the specific context, such as the relatively large territory of IS's state, the inability of local and international forces to provide alternatives to demobilized fighters, the lack of consensus within the international coalition and the diverging interests of neighboring states and regional powers (Walt 2015, p. 46; Watts 2015, pp. 159-61). Most importantly, perhaps, this strategy required patience, which was difficult to sustain in the wake of terrorist attacks in Europe and increasing refugee flows. Western powers deemed that the time needed to contain and gradually degrade IS was politically not viable, opting instead for an intensification of air raids, while arming and training local (Kurdish) forces for ground operations against the IS.

\subsection{Fratricide in the Jihadi Sub-System: The Rift between IS and Al-Qaeda}

The threat of compromising its global brand does not only concern IS's authority and interaction with the international -Westphalian — system, but also the jihadi (sub)system. In his study of jihadi pro-states, Brynjar Lia (2015) claims that one of the main characteristics of jihadi de facto states is that they are all intensely ideological and internationalist projects. Guided by the ideological imperative to establish Sharia and alter the border-delimitated world order, jihadi proto-states, like IS, often prefer to 'sacrifice state building on the altar of ideological purity'. According to Lia, two interlinked factors may explain this reluctance to forego their ideological rigidity: first, the dependence of jihadi proto-states on external constituencies, namely foreign fighters and donors, and second, their competition with rival jihadi groups (Lia 2015, p. 37). In other words, a jihadi proto-state needs to preserve its ideological edge to keep competition in check and attract more fighters and resources than its competitors.

Building on Lia's argument, this article claims that, above all, IS's rise constitutes a bid for increased power and influence vis-à-vis rival Islamist groups. The Caliphate was not restored in an ideological void or organizational vacuum. IS built on a long history and legacy of state-building paradigms within the salafi-jihadi movement (Lia 2015, pp. 34-35). By being the first one to venture building an 'Islamic State' of this magnitude and Islamic connotations, IS poses a direct challenge to other groups within the jihadi sub-system. The challenge is most direct towards the other jihadi claimant to a global brand, al-Qaeda.

The intra-movement rift between the so-called Islamic State and al-Qaeda was not the first one to rock the jihadi scene, but to this day, it has been the most spectacular. The beginning of the crisis can be traced to al-Baghdadi's decision, in April 2013, to move the forces of Islamic State in Iraq (ISI) into Syria and announce a merge with Jabhat al-Nusra. In Baghdadi's eyes, ISI was merely subduing a jihadi group, that he had sent to Syria, and which lately had been showing signs of disobedience 
(Hassan 2018, pp. 3-4). In the eyes of al-Nusra's leader, Abu Muhammad al-Julani, this was a violent take-over, which threatened his and his group's survival. In the eyes of the new al-Qaeda leader, Ayman al-Zawahiri, it was a direct challenge to al-Qaeda's long-held position as the main jihadi hub and brand within the jihadi movement.

$\mathrm{Al}$-Qaeda has a long history of internal disagreements and tense relations with affiliates. These internal tensions have been documented in al-Qaeda's long bureaucratic log of organizational blueprints and lengthy letter-exchanges. Studies of captured internal documents have identified several dividing lines within the wider salafi-jihadi movement, such as the divide between 'strategists' and 'doctrinaires', the global/local and the global/classical dichotomies (Lahoud et al. 2012; Moghadam and Fishman 2010). As a bureaucratic organization, al-Qaeda has been plagued also by financial quarrels, power struggles over recruits and territory and local leadership ambitions, which are exacerbated by the geographical distance and poor communication (Brachman and McCants 2006; Brown 2007; Byman 2014; Hamming 2019). The jihadi movement has also a history of internal fighting and cases of local forces going rogue. However, neither the fratricide that followed the Soviet withdrawal from Afghanistan nor the ultra-violent spree of GIA during Algeria's civil war (Hamming 2019) managed to stir the jihadi scene as much as Abu Bakr al-Baghdadi. Al-Baghdadi's demonstration of disrespect towards al-Qaeda was built on a history of often strenuous relations between al-Qaeda central and its Iraqi affiliate. However, despite some suggestions within the leadership core, Osama bin Laden never considered severing ties with its first leader, Abu Musab al-Zarqawi.

What was different in Baghdadi's challenge that forced al-Zawahiri to expel the group from al-Qaeda's ranks? According to Hagerty (2016), the relationship between al-Qaeda and its Iraqi affiliate hinges on four parameters: the levels of strategic cohesion, need fulfillment, trust, and communication between the two. Although the two groups never shared a common strategic outlook, their affiliation fulfilled some needs for both al-Qaeda and al-Zarqawi. Al-Qaeda gained a vigorous group that kept the organization relevant after post-9/11 setbacks. Al-Zarqawi, on the other hand, gained an affiliation with the al-Qaeda brand and the access this offered to recruits and sources of funding (Hagerty 2016, p. 15). Contrary to al-Zarqawi, Al-Baghdadi assumed that al-Qaeda no longer fulfilled the group's needs and that, after bin Laden's death, there was room for a new brand. The strategic 'misunderstanding' between the two was further fueled by the diminishing levels of trust and communication, both exacerbated by the geographic distance that separated the two groups.

Nevertheless, the al-Qaeda-ISIS rift was more than a misunderstanding. Access to new resources and recruitment opportunities in the Syrian conflict, offered ISIS the additional material incentives to disassociate itself from al-Qaeda. The Syrian civil war allowed ISIS much more maneuvering room for empowerment, compared to al-Qaeda leadership, which is long entrapped in the Af-Pak borderland. This change in the distribution of power within the jihadi movement spearheaded a re-balancing act, gradually turning the unipolar jihadi subsystem into an -aspiring-bipolar one. In the process, the jihadi subsystem entered a period of turbulence that eventually engulfed the entire movement.

According to Clint Watts (2016), the ISIS-al-Qaeda competition has gone through two distinct phases. The first, covering the period from summer 2013 until mid-2014, was dominated by 'destructive competition', that is competition centered around direct violence between the adversaries. After ISIS's march through Nineveh and the declaration of the Caliphate in Mosul, competition between the two has shifted to 'escalating'. Escalating competition largely resembles the outbidding strategy, which is often used by competing militant groups in an effort to outpace their adversaries. This transition, according to Watts, was made possible by the stabilization of the intra-jihadi territorial borders in Syria, which allowed the two adversaries to 'swivel their weapons outward ... solidifying their stake in a crowded global jihadist landscape' (Watts 2016, p. 3). Hamming (2017) agrees with the distinction, but claims that the first phase of the al-Qaeda-ISIS competition involved both destructive and escalating features.

This article posits that destructive competition, in terms of direct conflict between al-Qaeda and its Syrian affiliate and ISIS, was in reality limited. Apart from some skirmishes and localized fighting, the lion's share of anti-ISIS violence came from local jihadi forces, such as Ahrar al-Sham (as Islamic 
Front), rather than al-Qaeda affiliated al-Nusra (Bunzel 2014). The jihadi movement suffered from weak institutions, yet the degree of institutionalization within the movement, at least in terms of informal norms, routines, customs, and traditions (Bakke et al. 2012, p. 269), was high enough to prevent high-level fighting. Indeed, al-Zawahiri and a number of al-Qaeda affiliated ideologues, such as al-Maqdisi and Abu Qatada, initially stroke a didactic, yet conciliatory, tone in their messages to ISIS. The tone started to change after ISIS killed al-Nusra's emir in Raqqa and particularly after the assassination of Abu Khalid al-Suri, a founding member of Ahrar al-Sham and a prominent jihadi in Syria (Hamming 2017, pp. 74-75; Lahoud and Al-Ubaydi 2014, p. 4). In response, Al-Qaeda went as far as severing official ties and dubbing ISIS a Khawarij ${ }^{1}$ group (Jackson 2014); still though, both al-Nusra and al-Qaeda stopped short of calling for violence against ISIS, advocating the use of violence only as last resort (Hamming 2020, pp. 10-11; Skovgaard-Petersen 2017, pp. 30-31).

ISIS was not as chivalrous. Verbal attacks against al-Qaeda became all more explicit after Baghdadi's rebuttal of Zawahiri's 'ruling' in favor of al-Nusra. In Baghdadi's words, he had to 'chose the order of God over the orders that contravenes Allah in the letter [of al-Zawahiri]'. A year later, Baghdadi stood at the pulpit of Mosul's Grand al-Nuri Mosque to announce the restoration of the Caliphate. Although ISIS often flirted with the notion of takfir (excommunication) against al-Qaeda, it crossed the line only in the end of 2015, when an article featured in ISIS journal Dabiq (no.12), titled 'The Allies of al-Qa'ida in Sham: the End', explicitly called al-Nusra apostate (Hamming 2017, p. 75). By that time, however, intra-jihadi fighting in Syria had largely ceased and the competition had shifted to global outbidding.

After the declaration of Caliphate, ISIS shed the geographical references in its name, and as 'Islamic State' (IS) shifted its focus to the global propagation of the newly-created Caliphate and its new brand. IS's foray into the global scene was three-pronged. First, an outward propaganda campaign that took by storm the internet, raising eyebrows inside the jihadi online community and the western media. Building on previous efforts to modernize jihadi propaganda-namely al-Qaeda in the Arabian Peninsula (AQAP) journal Inspire-IS media production became the new golden standard in online propaganda. Sleek, edited down-to-the-detail and flirting with internet culture (e.g., memes) and gaming aesthetics, IS propaganda was selling a new-and competitive to al-Qaeda-brand and a new methodology (manhaj) to disgruntled Muslims around the world. This was a glaring effort on IS's part to outbid al-Qaeda in attracting recruits. Contrary though to al-Qaeda, IS had a 'state' to present to possible recruits, offering thus the option of 'civilian hijra' (immigration to the Caliphate), besides the career of 'foreign fighter'. IS made every effort to highlight this difference with al-Qaeda, often featuring scenes of serene daily life under the 'Islamic State' in its propaganda.

The second prong of IS's hegemony quest in the jihadi sub-system was the escalation of attacks on western countries. One possible explanation for the surge of IS-related attacks in western capitals is the international coalition's attacks on IS in Syria and Iraq. This explanation, which sees the rise of IS violence as a reaction to western attacks on its 'state', is supported by the fact that the rate of terrorist plots increased after the anti-IS coalition was formed and that countries actively participating in the coalition's operations were targeted to a larger extent (Nesser 2019, pp. 17-18). That was also the reasoning that IS's spokesman al-Adnani used to call for attacks against Europe in a number of statements issued in that period (Nesser et al. 2016, p. 5). Another possibility is that IS-related violence was a reaction to the efforts of some western countries to close the 'gates of hijra'. In this sense, tighter border controls and the implementation of travel restrictions on possible recruits have forced some to resort to domestic terrorism. IS's publications and Al-Adnani's statements, on occasions, explicitly referred to the increasing difficulties recruits faced in their effort to reach the Caliphate, urging them instead to conduct attacks against civilians in their countries of residence (Al-Adnani 2016;

1 Khawarij was the first dissident group within Islam. It was formed after the death of Prophet Muhammad expressing disagreements on how Muhammad's successor should be chosen. In Islamic parlance it has come to denote extremism and it is considered a very serious accusation. 
Dabiq 2015c, p. 54). A third explanation, and closer to this article's argument, is that this surge of terrorist attacks also constituted an open effort to outbid al-Qaeda on its preferential field: attacks on the far-enemy (Watts 2016). In this regard, the escalation of IS violence against western countries is essentially directed towards its jihadi antagonist, al-Qaeda, which has been long advocating attacks on the West, but lately has been having problems delivering such attacks.

The third conduit of al-Qaeda-IS competition took the form of a 'war of bay'as'. Prominent ideologues and jihadi groups around the world were called to take a stance on the al-Qaeda-IS conflict. Many felt the need to situate themselves on the new jihadi map, either reiterating their loyalty to al-Qaeda or siding with the new-comer. This resulted in a flurry of competitive pledges of oath; including Zawahiri, who renewed his oath to Mullah Omar and, when the death of Mullah Omar was announced, to his successor, Mullah Mansour. This war of bay'as ushered a period of alliance re-building in the jihadi movement. This process of system recalibration, local fragmentation and alliance-building, which affected most local jihadi scenes and conflicts, is explored in more detail in the following section.

\subsection{After the 'War of Words', the 'War of Bay'as': Alliance-Building and Fragmentation in the Age of the 'Caliphate'}

ISIS spokesperson, Abu Muhammad al-Adnani, had in effect announced the restoration of the Caliphate few weeks before al-Baghdadi's caliph-like appearance in Mosul. In his speech, al-Adnani stated that 'with this declaration of the caliphate, it is incumbent upon all Muslims to pledge allegiance to the Caliph Ibrahim and support him'. In the same vein, al-Adnani added that "the legality of all emirates, groups, states, and organizations becomes null by the expansion of the caliph's authority and arrival of its troops to their areas' (Al-Adnani 2014). The declaration of the Caliphate, thus, automatically posed a question of authority and allegiance; theoretically to all Muslims, but practically to the other groups in the jihadi movement.

With the help of technology, Adnani's call for bay'as ${ }^{2}$ reached the edges of the jihadi world. In a climate of heated debate, a flurry of online bay'as ensued. At that point, most of them were personal bay'as on social media (Holtmann 2014). Increasingly, though, collective baya's from jihadi groups started coming in. Since 2014, more than 40 groups, spanning an area from west Africa to southeast Asia, have pledged an oath of allegiance to al-Baghdadi. IS has displayed less restraint than al-Qaeda in accepting these bay'as, but nevertheless showed some caution. As early as November 2014, IS made its first round of acceptances, welcoming to its fold five jihadi groups form the Middle East. Not all bay'as were accepted, though. For instance, bay'as from Sinai, Libya, Yemen, Algeria, and the Arabian Peninsula (Saudi Arabia) resulted in the creation of wilayats (provinces), while in Caucasus and Khorasan (Af-Pak) they were delayed and other ba'yas were accepted, but not considered for official expansion (Dabiq 2014, p. 24). To justify the delays in accepting bay'as from some groups, IS put forward specific preconditions for the creation of new wilayats: unification of the jihadi forces operating in the area, nomination of a leader, a detailed plan of military conquest and submission of the 'file' to IS's central authorities for evaluation and approval (Dabiq 2015b, p. 35). These preconditions seemed to favor groups with established presence in their region, which had relatively fair chances to survive the aftermath of the bay'a.

Although IS's desire to affiliate with established groups that have operational potential is a plausible explanation, it fails to explain why the bay'a of practically non-existent groups in Algeria and Saudi Arabia was accepted in the first place. It appears more probable that expansion into Saudi Arabia was mainly guided by religious justifications and it was decided in the spirit of IS competition with al-Qaeda. In Algeria, the main motive might have been a desire to stir things within al-Qaeda in

2 Although the exact meaning of bay'a is not clear, it is used to denote a pledge of allegiance and submission to a person of authority. Originally it referred to allegiance to a Caliph (and the Prophet Muhammad himself), but later it was used more loosely. For more on this topic see (Milton and Al-Ubaydi 2015; Porter 2015; Wagemakers 2015). 
Islamic Maghreb (AQIM) and encourage possible defectors. It is equally noteworthy that none of the bay'as made by non-Arab groups were granted affiliation in this first round of acceptances (Milton and Al-Ubaydi 2015, p. 4). The first non-Arab wilaya was established in early 2015 in Af-Pak borderland (Khorasan Province), further highlighting the anti-al-Qaeda reasoning in IS's strategic planning. It is possible, then, that IS opted to begin its expansion with groups that, on the one hand, are smaller but possibly easier to manage (Milton and Al-Ubaydi 2015, pp. 4-5) and, on the other hand, are closer to its Syria/Iraq heartland, and possibly offer better communication channels. In 2015, IS confidence in its global aspirations grew as a result of the increasing tempo of attacks in western countries by small groups or individuals, who pledged bay'a to al-Baghdadi. This new-found confidence prompted IS to enlarge the circle of affiliates and include groups outside MENA.

IS's motivation to seek alliances in the jihadi movement seems rather straightforward. IS sought to create an arc of affiliates to claim a hegemonic role within the jihadi scene. IS expects little from its affiliates. Contrary to al-Qaeda that anticipated its affiliates to shift their priorities from local issues to fighting the far enemy, IS is content to leave its affiliates alone (Zelin 2015, p. 25). They are expected to operate under the banner of IS and they are expected to survive. In the best case scenario, these alliances might also convey logistical benefits to IS, such as streamlining fighters to Syria/Iraq (Milton and Al-Ubaydi 2015, p. 5). Apart from that, IS affiliates were free to organize their activity as they pleased.

Given that IS asked little from its affiliates, it is important to explore what IS offered in return. In other words, if alliances require a degree of need fulfilment on both sides, what the groups that pledged bay'a to IS expected from this affiliation. Their motivations run across the resources-ideology spectrum. Some groups were genuinely excited by the reestablishment of the caliphate (McCants 2016, p. 21). In this sense, they were driven by ideological considerations. These considerations occasionally stemmed from the local circumstances each group faced. The Islamic Movement of Uzbekistan (IMU) is an interesting example in this regard. Affiliated with al-Qaeda, but in close proximity to the Taliban, the foreign status of IMU in Af-Pak and its conflicts rendered the idea of IS borderless jihad more suited to IMU's goals than Taliban's nationalist aspirations (Jadoon 2018, p. 38).

In terms of resources-related motivations, some groups might have pledged allegiance to IS expecting financial rewards (Jadoon 2018, p. 32) or boosts in recruitment from the media attention their bay'a generated. IMU again is a case in point. Long detached from its main area of operations in Uzbekistan, IMU hoped that affiliation with IS will revive its influence within Uzbekistan and increase recruitment (Jadoon 2018, p. 38). Boko Haram also expected to attract more recruits from other West African countries and the diaspora, and possibly a better and wealthier pool of recruits beyond the 'poor al-majiri boys' profile of most Boko Haram's members (Zenn 2015, p. 21). Resources-related motivations were more central in low-end-operational-cooperation between IS and local groups, which expressed support but did not pledge bay'a to al-Baghdadi. This is most evident in Pakistan, where IS developed cooperative relations and conducted joint attacks with powerful groups, which did not fully share IS ideology, such as Lashkar-e-Islam (LeI), Jamaat-ul-Ahrar (JuA), Jundullah and the Balochistan National Army (Jadoon 2018, pp. 38-39; Rassler 2015, p. 9). Other groups might have been lured by the prospect of having access to IS's media apparatus, especially if they lacked a propaganda production mechanism of their own. IS-affiliated groups in Somalia are such an example. Although Al-Shabaab retained control of its very prolific media apparatus, the former al-Shabaab groups that pledged allegiance to IS could rely on IS central's media mechanism to produce and distribute their photos and videos from Somalia (Warner and Weiss 2017, p. 31). Boko Haram is also one of the organizations that benefited from better media production after their affiliation with IS (Milton and Al-Ubaydi 2015, p. 6).

While resources-related drivers varied across specific cases, a motivation shared by almost all groups was increased (local) political relevance (Jadoon 2018, p. 32). The motivation was particularly strong in groups operating in competitive jihadi environments. This quest for local power and relevance was only marginally related to the al-Qaeda-IS competition, but it was exceptionally destructive for 
local conflicts. It is no surprise, then, that most of the groups that pledged allegiance to IS were splinter-groups or factions from established (often al-Qaeda affiliated) organizations (Crone 2017, p. 69; McCants 2016, p. 21) These internal splits unwounded along old cleavages, regional differences or preexisting leadership disputes. They rested on divergences over interests and strategy or sometimes belied a more personal grudge, such as being overlooked in a promotion or stripped of personal fiefdoms. A case in point is the IS affiliate in Af-Pak, which attracted militants, who were unhappy with Taliban's peace negotiations with the government in Kabul. At the same time, the founders of the Khorasan Province were often passed over for leadership roles or profitable postings by the Taliban leadership (Rassler 2015, pp. 7-8; Sheikh 2017, p. 43). In the same vein, AQAP militants in Yemen, who broke away to form the IS-Yemen Province, accused AQAP that it was not doing enough to kill Shi'a Houthis (McCants 2016, p. 21). The case of AQAP also highlights the role of generational divides in movement fragmentation, as IS ideology has attracted primarily younger members of AQAP (Clausen 2017, p. 59).

In several cases geographical dispersal attenuated preexisting cleavages, festering poor communication and increasing intra-movement suppression costs. This is best evident in Somalia. Two factions split from al-Shabaab to join IS, one in northern Puntland region and the other in southern Somalia. The former, which is led by Abdulqadir Mumin, is the official IS branch in the region. It has also been the most active, with its biggest achievement being the brief capture of the port town of Qandala in Puntland (Weiss 2019, p. 29). The southern faction has been less formalized and less active. Yet, it has been the primary target of al-Shabaab efforts to stifle internal dissent. Al-Shabaab employed its internal security service, the Amniyat, to arrest and occasionally execute pro-IS members, but due to geographical distance from the Mumin-led Puntland group, it could only deploy it against the much more accessible southern factions (Warner and Weiss 2017, pp. 28-29). Likewise, Taliban were in a striking distance from IMU in Afghanistan. Thus, when IMU's leader Usman Ghazi pledged allegiance to al-Baghdadi, in the wake of the confirmation of Mullah Omar's death, Taliban could reach and defeat the Ghazi faction in November 2015, prompting some IMU members, who had followed Ghazi, to return to their fold (Jadoon 2018, pp. 37-38).

Weakness, as result of increased (state) counter-insurgency and military setbacks, has been at the core of some splits. For example, Egyptian army's crackdown in Sinai, in the wake of Morsi's ousting, possibly pushed Ansar Bayt al-Maqdis to make bay'a to IS (Lahoud 2015, p. 14). Likewise, the operations of the Pakistani army in the Federally Administered Tribal Areas (FATA) have been central motivation for the Orakzai and Bajaur factions of Tehrik-i-Taliban Pakistan (TTP) to switch allegiance to IS (Jadoon 2018, p. 36). Military pressure and weakness have also played a role in the case of Boko Haram. The large-scale military offensive, launched in February 2015, by Nigeria and neighboring countries (Chad, Cameroon and Niger) severely restrained Boko Haram (Crone 2017, p. 68; Cummings 2017, p. 24). Facing military setbacks and territorial losses, Boko Haram needed IS's global brand to project local relevance.

The previous discussion revealed a complex web of motivations, needs and strategic considerations behind the alliances that IS forged across the jihadi sub-system. These alliances materialized because they fulfilled some needs on both sides. Local groups benefited from media exposure, possible recruitment boosts, increased political relevance and opportunities to settle local scores with their mother-organizations. IS, on the other hand, was content with 'expanding' its global brand and solidifying its claim to hegemony within the jihadi subsystem. They did not compete directly for the same resources. Hence, they could take advantage of the benefits alliances offered without enduring the cost.

\section{Conclusions}

The meteoric rise of ISIS, in 2014, has taken the world by surprise. After being nearly decimated in the end of 2000s, the former al-Qaeda affiliate managed to break through the Iraqi borders and at its height control territory of a significant size. The article demonstrated that the ripples of IS's rise were 
felt across the international system and the jihadi subsystem. The declaration of the 'Caliphate' and al-Baghdadi's claim to the role of Caliph raised important questions regarding IS's interaction with the international order and the jihadi movement. The answers to these questions help us understand the true nature of IS's challenge and that of other groups that might try to emulate IS's paradigm in the future.

The article showed that, from mid-2014 until 2016, IS was by all accounts a de facto state, which though did not perceive itself as territorially bounded. Contrary to past examples of revolutionary states, it had no intention to fully 'socialize' in the system's norms and logic because it negated the premises of the Westphalian system, which contravenes the notion of a united ummah. Therefore, it does not see itself as part of and does not have any commitments towards the international community. All states but the 'Islamic State' are considered illegitimate and IS can offer them nothing more than a temporary truce. In this regard, by demanding the recognition of its supreme authority as a Caliphate, IS cannot succumb to the structural pressures to become a 'normal' state, without compromising its global brand. IS's extremism informed the discussion around possible strategies to counter its territorial growth and appeal. Although there were some proponents of a containment strategy, which rested on the idea that it is better to allow IS to fail rather than forcibly dismantle it, the international coalition opted for an active destruction strategy, assuming that containment would require time that, in light of IS's terrorist attacks and increasing refugee flows, was not available.

Concerns around its global brand do not only affect IS's authority and interaction with the international-Westphalian—system, but also the jihadi (sub)system. IS operates in a competitive jihadi market, which forces groups to preserve their ideological edge to keep competition in check and attract more fighters and resources than their competitors. By the same token, the article claims that, above all, IS's rise constitutes a bid for increased power and influence vis-à-vis rival Islamist groups. By being the first one to venture building an 'Islamic State' of this magnitude and Islamic connotations, IS poses a direct challenge to other groups within the jihadi sub-system. The challenge is most direct towards the other jihadi claimant to a global brand, al-Qaeda. Al-Baghdadi assumed that al-Qaeda no longer fulfilled ISI's needs and that, after bin Laden's death, there was room for a new brand. At the same time, the diminishing levels of trust and communication, both exacerbated by geographic distance, deepened the rift. Access to new resources and recruitment opportunities in the Syrian conflict, offered ISIS the additional material incentives to disassociate itself from al-Qaeda.

Drawing on Watts's (2016) exploration of IS-al-Qaeda competition, the article shows that IS-al-Qaeda rivalry has taken the form of 'destructive' and 'escalating competition'. However, contrary to Watts, the article posits that destructive competition, in terms of direct conflict between al-Qaeda and ISIS has been in reality limited, even in Syria, where the two groups were in direct contact. Apart from some skirmishes and localized fighting, the lion's share of anti-ISIS violence came from local jihadi forces. Although the jihadi movement traditionally suffers from weak institutions, high-level fighting between al-Qaeda and IS did not materialize, largely because the al-Qaeda leadership decided to keep a conciliatory tone in its 'war of words' against IS. At the same time, although ISIS often flirted with the notion of takfir against al-Qaeda, it crossed the line only in the end of 2015, when intra-jihadi fighting in Syria had largely ceased and the competition had shifted to global outbidding.

Instead, as the article shows, the rivalry between the two has been played out in three domains: propaganda, attacks on western targets and a 'war of bay'as'. The article, which mainly focuses on the latter, shows that the rift between al-Qaeda and IS forced prominent ideologues and jihadi groups around the world to situate themselves on the new jihadi map, either reiterating their loyalty to al-Qaeda or siding with the new-comer. This resulted in a flurry of competitive pledges of oath coming from all the corners of the jihadi movement. By initiating this 'war of bay'as' IS sought to create an arc of affiliates to claim a hegemonic role within the jihadi scene. IS expected little from its affiliates and gave little in return. Contrary to al-Qaeda, which expected its affiliates to fight the far enemy, IS was content to leave its affiliates to fight their local battles. Given that IS lacked the capacity to physically reach the entire umma, it chose to forge alliances with local same-minded forces that 
will carry its banner to the most remote corners of the umma. IS's international alliances materialized because IS and its affiliates do not compete in the same political and resource market.

In local contexts, however, the IS-al-Qaeda competition generated a cycle of intra-field rivalries and fragmentation. Most of the groups that pledged allegiance to IS were splinter-groups from established (often al-Qaeda affiliated) organizations. This local intra-field competition unwounded along old cleavages, regional differences or preexisting leadership disputes. In several cases geographical dispersal attenuated preexisting cleavages, festering poor communication and increasing intra-movement suppression costs. The motivations of local jihadi groups that pledged bay'a to IS run across the resources-ideology spectrum. Some groups were genuinely excited by the reestablishment of the caliphate, while others were driven by organizational concerns and (tangible and intangible) resources-related considerations, as the relevant scholarship predicts. Weakness, as result of increased (state) counter-insurgency and military setbacks, has been also at the core of some splits. A motivation shared by almost all groups was local political relevance and influence, especially for groups operating in competitive jihadi environments. This quest for local power and relevance was only marginally related to the al-Qaeda-IS competition, but it was exceptionally destructive for local conflicts.

Some alliances proved successful and lasting, while others, although announced with many hopes, were born stillborn (e.g., Algeria, Tunisia) or were quickly subsumed by their early successes (e.g., Libya and to some extent Yemen). IS's territorial losses in Syria and Iraq has taken a serious blow to IS brand. However, despite losing its capacity to 'remain', which has been the centerpiece of IS propaganda, IS manages to preserve most of its affiliates. The assassination of al-Baghdadi served an additional blow to IS, largely because the IS brand was built on a personality cult around al-Baghdadi. This renders the effort of his successor, Abu Ibrahim al-Hashimi al-Qurashi, to solicit support and authority harder (Bunzel 2019). Nevertheless, al-Baghdadi's death has instigated a flow of bay'a renewals from official wilayat and affiliated groups (Zelin 2019), demonstrating that IS, although severely weakened, remains relevant.

Funding: This research received no external funding

Conflicts of Interest: The author declares no conflict of interest.

\section{References}

Adamson, Fiona B. 2005. Globalisation, Transnational Political Mobilisation, and Networks of Violence. Cambridge Review of International Affairs 18: 31-49. [CrossRef]

Al-Adnani, Abu Muhammad. 2014. This Is the Promise of Allah. Global Terrorism Research Project: Islamic State. Available online: https://scholarship.tricolib.brynmawr.edu/bitstream/handle/10066/14242/ADN20140629. pdf? sequence $=1$ (accessed on 5 January 2020).

Al-Adnani, Abu Muhammad. 2016. And Those Who Lived [in Faith] Would Live Upon Evidence, (Audio and Transcript). Available online: https://www.memri.org/tv/isis-spokesman-abu-muhammad-al-adnani-callssupporters-carry-out-terror-attacks-europe-us (accessed on 23 March 2020).

Al-Shishani, Murad Batal. 2014. The Islamic State's Strategic and Tactical Plan for Iraq. Terrorism Monitor 12: 6-7.

Armstrong, David. 1993. Revolution and World Order: The Revolutionary State in International Society. Oxford: Clarendon Press.

Asal, Victor H., and R. Karl Rethemeyer. 2008. The Nature of the Beast: Terrorist Organizational Characteristics and Organizational Lethality. Journal of Politics 70: 437-49. [CrossRef]

Asal, Victor H., Gary A. Ackerman, and R. Karl Rethemeyer. 2012. Connections Can Be Toxic: Terrorist Organizational Factors and the Pursuit of Cbrn Weapons. Studies in Conflict E Terrorism 35: 229-54.

Asal, Victor H., Hyun Hee Park, R. Karl Rethemeyer, and Gary Ackerman. 2016. With Friends Like These ... Why Terrorist Organizations Ally. International Public Management Journal 19: 1-30. [CrossRef]

Bacon, Tricia. 2014. Alliance Hubs: Focal Points in the International Terrorist Landscape. Perspectives on Terrorism 8: 4-26.

Bacon, Tricia. 2018. Is the Enemy of My Enemy My Friend? How Terrorist Groups Select Partners. Security Studies 27: 345-78. [CrossRef] 
Bakke, Kristin M., Kathleen Gallagher Cunningham, and Lee J. M. Seymour. 2012. A Plague of Initials: Fragmentation, Cohesion, and Infighting in Civil Wars. Perspectives on Politics 10: 265-83. [CrossRef]

Bapat, Navin A., and Kanisha D. Bond. 2012. Alliances between Militant Groups. British Journal of Political Science 42: 793-824. [CrossRef]

Barnett, Michael N. 1996. Identity and Alliances in the Middle East. In The Culture of National Security: Norms and Identity in World Politics. Edited by Peter Katzenstein. New York: Columbia University Press, pp. 400-47.

Bloom, Mia. 2005. Dying to Kill: The Allure of Suicide Terror. New York: Columbia University Press.

Brachman, Jarret M., and William McCants. 2006. Stealing Al-Qa'ida's Playbook. West Point: Combating Terrorism Center at West Point.

Brown, Vahid. 2007. Cracks in the Foundation: Leadership Schisms in Al-Qa'ida 1989-2006. West Point: Combating Terrorism Center at West Point.

Bunzel, Cole. 2014. The Islamic State of Disunity: Jihadism Divided. Jihadica. Available online: http: //www.jihadica.com/the-islamic-state-of-disunity-jihadism-divided/ (accessed on 30 January 2020).

Bunzel, Cole. 2015. From Paper State to Caliphate: The Ideology of the Islamic State. Washington: Center for Middle East Policy, Brookings.

Bunzel, Cole. 2019. Caliph Incognito: The Ridicule of Abu Ibrahim Al-Hashimi. Jihadica. Available online: https://www.jihadica.com/caliph-incognito/ (accessed on 25 January 2020).

Byman, Daniel. 2014. Buddies or Burdens? Understanding the Al Qaeda Relationship with Its Affiliate Organizations. Security Studies 23: 431-70. [CrossRef]

Christia, Fotini. 2012. Alliance Formation in Civil Wars. Cambridge: Cambridge University Press.

Clausen, Maria-Louise. 2017. Islamic State in Yemen-a Rival to Al-Qaeda? Connections 16: 50-62. [CrossRef]

Conrad, Justin, and Kevin Greene. 2015. Competition, Differentiation, and the Severity of Terrorist Attacks. The Journal of Politics 77: 546-61. [CrossRef]

Cragin, Kim, Peter Chalk, Sara A. Daly, and Brian A. Jackson. 2007. Sharing the Dragon's Teeth: Terrorist Groups and the Exchange of New Technologies. Santa Monica: Rand Corporation.

Crone, Manni. 2017. Islamic State's Incursion into North Africa and Sahel: A Threat to Al-Qaeda? Connections 16: 63-76. [CrossRef]

Cummings, Ryan. 2017. A Jihadi Takeover Bid in Nigeria? The Evolving Relationship between Boko Haram and Al-Qa'ida'. CTC Sentinel 10: 24-29.

Dabiq. 2014. Remaining and Expanding. Vol. 5, al-Hayat Media Center: Islamic State.

Dabiq. 2015a. Just Terror. Vol. 12, al-Hayat Media Center: Islamic State.

Dabiq. 2015b. From Hypocrisy to Apostasy: The Extinction of the Grayzone. Vol. 7, al-Hayat Media Center: Islamic State.

Dabiq. 2015c. From the Battles of Al-Ahzāb to the War of Coalitions. Vol. 11, al-Hayat Media Center: Islamic State.

Dabiq. 2015d. Shari'ah Alone Will Rule Africa. Vol. 8, al-Hayat Media Center: Islamic State.

Fearon, James D. 1995. Rationalist Explanations for War. International organization 49: 379-414. [CrossRef]

Gade, Emily Kalah, Michael Gabbay, Mohammed M. Hafez, and Zane Kelly. 2019. Networks of Cooperation: Rebel Alliances in Fragmented Civil Wars. Journal of Conflict Resolution 63: 2071-97. [CrossRef]

Hafez, Mohammed M. 2017. Fratricidal Rebels: Ideological Extremity and Warring Factionalism in Civil Wars. Terrorism and Political Violence, 1-26. [CrossRef]

Hagerty, Vivian G. 2016. Terrorist Divorce: Examining Alliance Break-Ups and the Al Qaeda/ISIL Split. Clocks and Clouds 6: 1-22.

Halliday, Fred. 1999. Revolution and World Politics: The Rise and Fall of the Sixth Great Power. London: Macmillan Press. Hamming, Tore Refslund. 2017. Jihadi Competition and Political Preferences. Perspectives on Terrorism 11: 63-88. Hamming, Tore Refslund. 2019. Polemical and Fratricidal Jihadists: A Historical Examination of Debates, Contestation and Infighting within the Sunni Jihadi Movement. London: The International Centre for the Study of Radicalisation and Political Violence (ICSR).

Hamming, Tore Refslund. 2020. The Al Qaeda-Islamic State Rivalry: Competition Yes, but No Competitive Escalation. Terrorism and Political Violence 32: 20-37. [CrossRef]

Hassan, Hassan. 2018. Two Houses Divided: How Conflict in Syria Shaped the Future of Jihadism. CTC Sentinel 11: $1-8$.

Holsti, Ole R., P. Terrence Hopmann, and John D. Sullivan. 1973. Unity and Disintegration in International Alliances: Comparative Studies. New York: Wiley. 
Holtmann, Philipp. 2014. The Different Functions of IS Online and Offline Plegdes (Bay'at): Creating a Multifaceted Nexus of Authority. Jihadology. Available online: https://jihadology.net/2014/11/15/guest-post-the-differentfunctions-of-is-online-and-offline-plegdes-bayat-creating-a-multifaceted-nexus-of-authority/ (accessed on 23 January 2020).

Horowitz, Michael C. 2010. Nonstate Actors and the Diffusion of Innovations: The Case of Suicide Terrorism. International Organization 64: 33-64. [CrossRef]

Horowitz, Michael C., and Philip B. K. Potter. 2014. Allying to Kill: Terrorist Intergroup Cooperation and the Consequences for Lethality. Journal of Conflict Resolution 58: 199-225. [CrossRef]

Jabareen, Josef. 2015. The Emerging Islamic State: Terror, Territoriality, and the Agenda of Social Transformation. Geoforum 58: 51-55. [CrossRef]

Jackson, Kevin. 2014. Al-Qaeda Revives Its Beef with the Islamic State. Jihadica. Available online: http: //www.jihadica.com/al-qaeda-revives-its-beef-with-the-islamic-state/ (accessed on 25 January 2020).

Jadoon, Amira. 2018. Allied and Lethal: Islamic State Khorasan's Network and Organizational Capacity in Afghanistan and Pakistan. West Point: Combating Terrorism Centre at West Point.

Jones, Seth G., James Dobbins, Daniel Byman, Christopher S. Chivvis, Ben Connable, Jeffrey Martini, Eric Robinson, and Nathan Chandler. 2017. Rolling Back the Islamic State. Santa Monica: Rand Corporation.

Kalyvas, Stathis N., and Matthew Adam Kocher. 2007. How "Free" Is Free Riding in Civil Wars?: Violence, Insurgency, and the Collective Action Problem. World Politics 59: 177-216. [CrossRef]

Karmon, Ely. 2005. Coalitions between Terrorist Organizations: Revolutionaries, Nationalists and Islamists. Leiden: Martinus Nijhoff Publishers.

Lahoud, Nelly, Stuart Caudill, Liam Collins, Gabriel Koehler-Derrick, Don Rassler, and Muhammad Al-Ubaydi. 2012. Letters from Abbottabad: Bin Ladin Sidelined? West Point: Combating Terrorism Center at West Point.

Lahoud, Nelly, and Muhammad Al-Ubaydi. 2014. The War of Jihadists against Jihadists in Syria. CTC Sentinel 7: $1-6$.

Lahoud, Nelly. 2015. The Province of Sinai: Why Bother with Palestine If You Can Be Part of the 'Islamic State'? CTC Sentinel 8: 12-14.

Lia, Brynjar. 2015. Understanding Jihadi Proto-States. Perspectives on Terrorism 9: 31-41.

Maoz, Zeev. 1996. Domestic Sources of Global Change. Ann Arbor: University of Michigan Press.

McCants, William. 2016. The Polarizing Effect of Islamic State Aggression on the Global Jihadist Movement. CTC Sentinel 9: 20-23.

Milton, Daniel, and Muhammad Al-Ubaydi. 2015. Pledging Bay'A: A Benefit or Burden to the Islamic State? CTC Sentinel 8: 1-7.

Moghadam, Assaf, and Brian Fishman. 2010. Self-Inflicted Wounds: Debates and Divisions within Al-Qa'ida and Its Periphery. West Point: Combating Terrorism Center at West Point.

Moghadam, Assaf. 2015. Terrorist Affiliations in Context: A Typology of Terrorist Inter-Group Cooperation. CTC Sentinel 8: 22-25.

Moghadam, Assaf. 2017. Nexus of Global Jihad: Understanding Cooperation among Terrorist Actors. New York: Columbia University Press.

Nemeth, Stephen. 2014. The Effect of Competition on Terrorist Group Operations. Journal of Conflict Resolution 58: 336-62. [CrossRef]

Nesser, Petter, Anne Stenersen, and Emilie Oftedal. 2016. Jihadi Terrorism in Europe: The Is-Effect. Perspectives on Terrorism 10: 3-24.

Nesser, Petter. 2019. Military Interventions, Jihadi Networks, and Terrorist Entrepreneurs: How the Islamic State Terror Wave Rose So High in Europe. CTC Sentinel 12: 15-21.

Oots, Kent Layne. 1989. Organizational Perspectives on the Formation and Disintegration of Terrorist Groups. Studies in Conflict \& Terrorism 12: 139-52.

Phillips, Brian J. 2019. Terrorist Group Rivalries and Alliances: Testing Competing Explanations. Studies in Conflict $\mathcal{E}$ Terrorism 42: 997-1019.

Porter, Geoff D. 2015. What to Make of the Bay 'a in North Africa? CTC Sentinel 8: 14-6.

Posen, Barry R. 1993. The Security Dilemma and Ethnic Conflict. Survival 35: 27-47. [CrossRef]

Rassler, Don. 2015. Situating the Emergence of the Islamic State of Khorasan. CTC Sentinel 8: 7-11.

Rich, Paul B. 2016. How Revolutionary Are Jihadist Insurgencies? The Case of ISIL. Small Wars E Insurgencies 27: 777-99. 
Sheikh, Mona Kanwal. 2017. Islamic State Enters Al-Qaeda's Old Hotbed: Afghanistan and Pakistan. Connections 16: 37-49. [CrossRef]

Skovgaard-Petersen, Jakob. 2017. Heirs of Abu Bakr: On the Ideology and Conception of History in Al-Qaeda and Islamic State. Connections 16: 25-36. [CrossRef]

Staniland, Paul. 2012. Between a Rock and a Hard Place: Insurgent Fratricide, Ethnic Defection, and the Rise of Pro-State Paramilitaries. Journal of Conflict Resolution 56: 16-40. [CrossRef]

Vu, Tuong, and Patrick Van Orden. 2019. Revolution and World Order: The Case of the Islamic State (ISIS). International Politics 57: 57-78. [CrossRef]

Wagemakers, Joas. 2015. The Concept of Bay 'a in the Islamic State's Ideology. Perspectives on Terrorism 9: 98-106. Walt, Stephen M. 1987. The Origins of Alliances. Ithaca: Cornell University Press.

Walt, Stephen M. 1992. Revolution and War. World Politics 44: 321-68. [CrossRef]

Walt, Stephen M. 1996. Revolution and War. New York: Cornell University Press.

Walt, Stephen M. 2015. ISISs as Revolutionary State. Foreign Affairs 94: 42-51.

Warner, Jason, and Caleb Weiss. 2017. A Legitimate Challenger? Assessing the Rivalry between Al-Shabaab and the Islamic State in Somalia. CTC Sentinel 10: 27-32.

Watts, Clint. 2015. Let Them Rot: The Challenges and Opportunities of Containing Rather Than Countering the Islamic State. Perspectives on Terrorism 9: 156-64.

Watts, Clint. 2016. Deciphering Competition between Al-Qa'ida and the Islamic State. CTC Sentinel 9: 1-6.

Weiss, Caleb. 2019. Reigniting the Rivalry: The Islamic State in Somalia Vs. Al-Shabaab. CTC Sentinel 12: 29-35.

Zelin, Aaron. 2015. The Islamic State's Model. In Islamism in the IS Age, 24-28: Project on Middle East Political Science (POMEPS). Available online: https://pomeps.org/wp-content/uploads/2015/03/POMEPS_Studies_12 ISAge_Web.pdf (accessed on 17 January 2020).

Zelin, Aaron. 2019. The Islamic State's Bayat Campaign. Jihadology. Available online: https://jihadology.net/2019/ 11/03/the-islamic-states-bayat-campaign/ (accessed on 30 January 2020).

Zenn, Jacob. 2015. A Biography of Boko Haram and the Baya to Al-Baghdadi. CTC Sentinel 8: 17-21.

(C) 2020 by the author. Licensee MDPI, Basel, Switzerland. This article is an open access article distributed under the terms and conditions of the Creative Commons Attribution (CC BY) license (http://creativecommons.org/licenses/by/4.0/). 
Article

\title{
Crusaders in Reverse? The Emergence of Political Islam in the Middle East and the Reactions of British Foreign Policy, 1978-1990
}

\author{
Ihab Shabana \\ Department of Political Sciences and International Relations, University of Peloponnese, GR-20132 Corinth, \\ Greece; ishabana@uop.gr
}

Received: 8 March 2020; Accepted: 14 April 2020; Published: 17 April 2020

\begin{abstract}
British foreign policy in the Middle East has been well researched. However, there are still aspects of Britain's approach towards the Middle East and North Africa (MENA) that have yet to be researched. One such aspect is Britain's encounter with the rise of political Islam in MENA and the way(s) in which this phenomenon was deciphered. Even though political Islam dates back to the late 19th and early 20th century, our study focuses on the period between the turbulent years of the outburst of the Iranian Revolution in 1978-1979 and its widely-felt influence until 1990. Our methodological tools include Foreign and Commonwealth Office (FCO) archival material that addresses the phenomenon of political Islam and its implications for British interests and international relations in general. We choose the concept of political Islam and its adherents that are widely acknowledged as political, comparatively to those of da'wa and Jihadi Islamism. We argue that British officials were widely influenced by the intellectual debates of the period under consideration and that they mainly adopted four analytical schemas which focused firstly on the rise of sectarian politics in MENA, secondly on the gradual accommodation of non-state actors and organizations in political analysis, thirdly on the worrisome prospect of an alliance between Islamist and communist forces, and lastly on the prevalence of the idea of Islamic solidarity and Islamic exceptionalism in exerting international politics. Our findings suggest that, at times, the FCO approaches the issue of political Islam with a reassuring mindset, focusing on its divisions and weaknesses, while at other times it analyzes it with a grave concern over stability and Britain's critical interests.
\end{abstract}

Keywords: political Islam; Islamism; Middle East; Britain; Foreign and Commonwealth Office; Iran; Shi'a; Lebanon; transnationalism

\section{Introduction: Religion in International Relations}

For most of the 20th century, religion was kept at the margins of international relations (IR) analysis. For many scholars, be they historians, sociologists, or political scientists, religion was no longer a driving force in history. Nevertheless, the 'death of god' in the secular age, as Charles Taylor described it, was not so overwhelming, since people all over the world have come to seek for plenitude of their identity (Taylor 2007, pp. 1-24). Since the 1970's, religious feeling has been strengthening in the Middle East and North Africa (MENA) region, yet it has also surfaced in the West, with the powerful emergence of religious discourses, such as the paradigms of Christian or Jewish millennialism.

By the same token, IR were undoubtedly influenced. For example, the consolidation of religious discourse in the practice of IR was facilitated by a number of variables. First, religion offered the mechanisms of legitimization by making use of symbolism that allowed the solidification of ethical and value systems. Second, the need for satisfying domestic constituencies regarding external relations often led to the adoption of a religion-based discourse. Third, religion provided ground for making the use of violence against domestic or international enemies applicable and justifiable (Fox 2009, 
pp. 277-79). This was the case with Iran during the war with Iraq in the 1980's, when the Iranian state discourse focused on the need for defending the 'sacred' Iranian Revolution that would eventually bring the 'hidden Imam' back.

In Britain, especially during the 1970's and 1980's, a vivid debate occurred within IR theory known as the 'English School', which recognized an escalation of the influence of the civilizational/religious nexus in the theory and practice of IR (Dunne 1999, pp. 418-19), challenging the absolutism of the Westphalian secular system. As we observed during the aforementioned period, the religious variable intersects and provides an essential framework of analysis (Omer n.d., p. 129). Therefore, what is at stake in this article is to keep track and explicate the itineraries of FCO interpretations relating to the rise of political Islam during the period of historical transformations in the Middle East. By doing so, our study tries to fill a missing part in the scholarship of British foreign policy, especially in a period of high Cold War tensions. After considering Britain's, the USSR's, and the US's early responses to political Islam, this paper's structure delves into the FCO's reactions to the emergence of Islamism. The points addressed reveal the growing tensions between approaches related to Britain's interests, the Cold War political polarization, and the evident growing influence of cultural history in foreign policy.

\section{Discussion}

This paper outlines an historical approach to British foreign policy on the rise of political Islam. While most literature gives an account of international relations from the perspective of this period's power struggles and particularly under the 'Cold War lenses', our approach focuses on the FCO's attempt to stress the importance of social structures, social relations, and social knowledge not as background material but as fundamental historical driving forces (Wood 1978, p. 348). Despite the dominant articulation of the nation, based on identity, our goals here are twofold. First, to stress the importance of translocality in MENA, which is dependent on socio-political dynamics. This translocality is able to reframe the context of identity formation towards a more culture-based that transcends state boundaries (Mandaville 2001, p. 2). Second, our goals are to unravel the facets of British foreign policy analysis concerning the thorny issue of political Islam and its implications for MENA countries and for other major powers in the region, such as the US.

IR scholarship has not paid much attention to the influence of religion in IR (Hasler n.d., p. 138). Given the paradigm shift of social sciences and political history during the 1970's-from grand narrative to a focus on cultural history and identity politics-we note the influence of these transformations to the FCO and, by extension, its approach to MENA regional politics with the use of the nexus of culture and religion. To a certain extent, the English School of IR challenged the position of the non-existent or the marginalized role of religion in the field, acknowledging religion as an aspect of culture and its functionality in social and political relations. Scholars from the English School realized, during the 1970 's, that interactions with non-western cultures, particularly in relation to Islam, formed a certain view within IR theory (Thomas 2001, p. 922).

Our main argument is that in the 1970's political history embedded in its analysis on the rise of political Islam a variety of elements from the emerging fields of social and cultural history. As British scholar Martin Wright maintained in the historical sociology of state systems, religion should be taken seriously, since the main historical religions cast doubts on the progressive character of modernity (Thomas 2001, p. 924). Martin Wight's academic activism in the 1960's influenced distinguished members of the FCO through their interaction in the British Committee meetings (Hall 2014, p. 966).

Our study found that a number of institutions inside the FCO, such as the Near East and North Africa Department (NENAD) or the Middle East Department (MED), moved their analysis towards a cultural/religious and sectarian approach in order to disentangle social relations and transformation inside MENA countries and their causal mechanisms that molded these dynamics into a coherent regional and international foreign policy. During the period under consideration, religious/ethnic identities emerged as an all-important component in local and global politics. Prominent religious 
figures created a hybrid revolutionary religious/political discourse exerting considerable influence on local, regional, and international politics.

\section{The Great Power's Foreign Policies and Reflections on Political Islam}

Even before the Cold War, the Great Powers tried to counterbalance Islamist politics. For instance, British specialists on MENA saw Islam as an obstacle for the spread of communism in the Arab world (Vaughan 2005, p. 152). Hence, British authorities tried to manipulate early political Islam and its organizations, such as the Muslim Brotherhood (M.B.) in Egypt during the WW II. ${ }^{1}$ The manipulation included the incorporation of moderate Islam to the ideas of modernization and human rights, but most importantly the struggle against communist ideas (Callaghan 2007, p. 211). ${ }^{2}$ Moreover, the rising American hegemony, the economic weakness that World War II brought, and the loss of Commonwealth territories provoked the need for altering the means of influence for Britain in the Middle East (Mayhew 1950, p. 477).

The USSR, in an attempt to manipulate the dynamics of its Muslim population, adopted a system of analysis concerning the origins, the nature, and the perspectives of Islam and its politicized forms since the beginning of the 1920's. After Stalin's persecutions, Brezhnev and eventually Andropov signaled a more consensual approach to Muslim populations, specifically by trying to manipulate ethnic/religious leaders in Central Asia (Fowkes and Gökay 2009, p. 2). At the same time, notwithstanding, the USSR's analysis of political Islam was used as a political tool for hampering capitalism's spheres of influence. More specifically, while after 1979 and for many years on, Islamist power in Iran was perceived as a liberating, egalitarian force, especially vis-à-vis American hegemony. Concomitantly, in Afghanistan, it was understood as a threat to the promising socialist project of the Soviets. Indeed, the USSR and its institutions, such as the Moscow Institute for Oriental Studies and the Communist University for the Toilers of the Orient, developed a number of schemas on the character of Islam throughout the 20th century. Some of them pointed out the compatibility of Islam with the founding principles of communism, such as those of Z. and N. Zavshirvanov and V. Ditiakin, and those that stressed Islam's enmity towards socialist aspirations, such as those of E. Beliaev and L. Klimovich (Kemper 2009, pp. 5-26). ${ }^{3}$

In tandem, US policy towards Islamic revival had also endured two bifurcations. In an attempt to engage with the Muslim world and secure its own interests, US policy experts attempted to maintain equilibrium between extremist and moderate forms of political Islam during the second half of the 20th century (Maghraoui 2006, p. 27). For instance, in certain contentious episodes, American foreign policy had a twofold approach: while supporting movements of political Islam in some countries like Afghanistan, it did oppose them in others such as Lebanon and Iran (Bill 1989, p. 135). Nevertheless, from time to time, Iran's Islamist movements were the object of support by western policy makers, especially when it came time to address dynamic leftist movements. Such was the case with Britain's support to the Iranian authorities in order to crash Tudeh party between 1983-1985 (Aslani 2020) or to manipulate moderate (or established) Islam as a tool for fighting extremism (Maghraoui 2006, p. 27). However, the British often disparagingly referred to the American 'tendency to treat all [Middle East] issues as military problems', ${ }^{4}$ even if the issues at stake were essentially political.

1 People's History Museum (PHM), CPGB Archive, CP/CENT/INT/56/03, Egypt, The Green Shirts, agents of International Fascism, 1942.

2 After WWII, Britain, indeed, put effort to promote an image of coexistence with the Arab world and Islam through cultural channels. In 1952, the magazine al-Aalam was launched in order to promote 'the theme of friendship and mutual respect between the Western and the Arab world'.

3 More specifically, the early works of Soviet scholars regarding (political) Islam include those of Z. and N. Zavshirvanov, The Communist Trends in the History of Muslim Civilization (1923), V. Ditiakin, Marx and Engels on the Origins and Character of Islam (1927), S. Asfendiarov, Reasons for the Emergence of Islam (1928), E. Beliaev, The Origin of Islam and its Class Basis (1930), and L. Klimovich, The Socialist Construction in the East and Religion (1929).

4 British National Archives (BNA), NF 226/1, W98C, D.H. Gillmore to J. Moberly, "Trilateral Meeting at the IISS", 10/11/1981. 
The Suez Crisis of 1956 signaled the end of British hegemony in the MENA region. Nevertheless, since the withdrawal of the British troops from the Persian Gulf in 1971, Downing Street launched a different approach to its Middle East foreign policy. This 'new role' was characterized by two variables. The first one was the fact that British interests should be promoted through London's special relationship with Washington, with London remaining at the same time the leading power in European affairs (Çavuşoğlu 2018, p. 39). The second one was that Britain's main concern was to also keep close ties with its Arab-Muslim allies, acknowledging their demands and, at least rhetorically, attempting to identify with them, as seen for instance in the example of the Israeli-Palestinian conflict. Thus, as Çavuşoğlu suggests, Britain opted to become 'freed of being the target of anti-imperialism criticisms', maintaining its ability to exert 'considerable influence' (Çavuşoğlu 2018, p. 42).

This dual role (Rynhold and Spyer 2007, p. 137), as perceived by British diplomats, would help Britain remain strong and influential in the region. Given the rising tensions in internal British politics regarding a mounting political and ethical conservatism (Garnett and Lynch 2009, p. 406) and a rising Islamic activism (Hamid 2018, pp. 1-14), British polity faced a number of critical dilemmas. As it was assessed in 1978, commercial interests in MENA could not be affected by the rise of political Islam thanks to the fact that the revival of Islamic consciousness, which was not directly connected to Islamic extremism. Hence, British intendants encountered the formation of a nascent 'critical Islam', as P. Mandaville coined it, and not necessarily the hegemony of a retrogressive belligerent militant Islamism (Mandaville 2001, p. 4). For instance, in 1978, British officials strongly doubted 'that there is a genuine widespread religious revival in the Muslim world'. ${ }^{5}$ Islamic revivalism mostly represents, according to FCO's early views, an attempt by a small number of extremists to impose their views upon the masses. This is what J.P. Bannerman from the FCO Research Department underlined to Mr. Lucas from MED in 1978, manifesting his reassurance about political Islam:

I am reluctant to take on a global study of Islam and its political influence [ . . ] because I do not believe there is sufficient political, or for that matter religious, cohesiveness in Islam to justify such a study by us. ${ }^{6}$

However, when the seizure of the Grand Mosque in Mecca in November 1979 took place, the British were alarmed with the prospects and dynamics of the Islamist movement. This was mainly related to the fact that Saudi Arabia was one of the main allies in the region, while Iran, already a rival by then, was trying to globalize Islamist ideas. A conversation between British diplomats in Washington and the American security advisor Zbigniew Brzezinski in 1979 discloses that the latter was highly concerned about the Mecca Incident and its ramifications in a transnational perspective. ${ }^{7}$ Therefore, diplomatic orientation often retreats to give space to strategic orientation, which mainly considers the containment of radical anti-western forces as the most fundamental issue in MENA (Rynhold and Spyer 2007, p. 138).

\section{Transnational Religious Ideology and Network Dynamics}

One of the fundamental aspects that the FCO detected was the transnational character of political Islam. Thus, the first point that we outline here is the perspective of transnational religious ideology and its impacts on MENA regional relations and stability. This hermeneutical approach concerns religious/ethnic cross-border connections, the dynamics of these connections, and networks and their consequences on regional politics, with a specific concern for the Persian Gulf, which was regarded as an area privileged by Britain. What we draw from our archival material is the attention paid-or sometimes not paid-to the agency of these networks as a significant manifestation for the local

BNA, FCO 93/4048, NF 031/1, "Islamic Revival", Bannerman to Lucas, 16/5/1978.

BNA, FCO 93/4048, NF 031/1, "Islamic Revival", Bannerman to Lucas, 16/5/1978.

BNA, FCO 8/3419, NB5 014/5, "Unrest in Saudi Arabia: A Talk with Brzezinski", November 1979. 
communities' dynamics, as proposed by Mabon and Wastnidge, (Mabon and Wastnidge 2019, p. 597), but also their horizons of expectations.

However, political Islam was not the unique means of contentious politics in the MENA region; for many analysts, it was a language and a tool against the western heritage of 'aggressive secularism' and its undisputable rejection, as FCO officials labeled it, and it was used by both state apparatuses-like in the case of Algeria-and opposition groups. ${ }^{8}$ The reflections of Islam in the political processes in the period before and after the Iranian revolution, illustrates the growing concerns about political ideology in the Arab-Muslim world and its mounting anti-western character. For example, the FCO repeatedly received reports from its embassies in MENA that underlined the revived interest on Islam. One such example is Iran, where the role of the clergy to the opposition of the Shah is underlined, or Algeria, where it 'remain[ed] a foundation of national unity'.9

In a conference at Chatham House in 1981, the FCO's research department found Professor's J. Piscatori's analysis for the strands of political Islam very revealing. Piscatori stressed that political Islam had four facets. The first was the 'conservative orthodox' who supported the rigorous application of Islam's commands. The second was the political strand (or the 'leftist' as he coined it) that adopted a more realistic and egalitarian discourse. The third was the most materialist strand, as it perceived Islam as a secondary factor in the driving forces in history and focused on social and economic aspects. The fourth bifurcation was the secularist camp. The 'secularists' believed that proper development of political and social structures is imperative but meanwhile sought to manipulate Islam for the sake of common good. British diplomats underlined that the West should pay more attention on the last strand. ${ }^{10}$

British officials were particularly worried about the effects of Shi'a political Islam in the Gulf during the first years after the Iranian revolution. Thus, British foreign policy moved towards a securitization approach on Gulf politics, especially after 1979. Even though British officials did not predict serious Shi'a mobilization in the Gulf, they kept a close eye on Shi'a population in the region and cooperated with local monarchies (Çavuşoğlu 2018, p. 50). The main reason for this transformation was the fear for influence of the Shi'a revolutionary mobilization in the Gulf countries. Despite the fact that the FCO acknowledged that the Sunnis in the Gulf did not likely share the same views on Islamic political organization, they still feared that the Sunnis could draw inspiration from the dynamics of the Iranian revolution. A case in point is Oman, one of the strongholds of London's influence, which was viewed as a potential fertile ground for an upsurge of Islamic radicalism. British specialists observed that for a large section of the Omanis, traditionalism was a vital component of social cohesion. The FCO assumed that an erosion of this cohesion as well as the social dynamics of the demographic boom-given that an increasing number of youths were taking religion more seriously within a social context—could cause social turmoil. At the same time, Ibadhism, even in its most radical form, was not perceived as a threat since it was viewed as a counterbalance to the dynamic and more fanatical sect of the khawarij. ${ }^{11}$

Throughout the 1980's, Shi'a sectarian politics in the United Arab Emirates (UAE) was not treated as a genuine threat for British interests and political stability. The political and economic importance of the community of approximately 10,000 Shi'a was limited to the economic activities of some important families, such as the Nuwais. Their key positions in state businesses and the importance of trade vis-à-vis political mobilization downplayed their threat to Gulf stability. In addition, according to an FCO 1983 assessment, the Shi'a immigrant population in the UAE was not likely to pose a political

8 BNA, NF 226/1, W98C, R.O. Miles (N. East and N. Africa Dept.) to B.L. Strachan Esq. CMG (Algiers), “Islam and Politics", 27/08/1981.

9 BNA, FCO 93/4048, NF 226/1, Telegraph, Algiers to London, 19/9/1978.

10 BNA, NF 226/1, W98C, Middle East Section Research Department, "Chatham House Conference on Islam in the Political Process", 14/07/1981.

11 BNA, FCO 8/6504, NB 226/1, “Islamic Fundamentalism”, 7/6/1987. 
threat. $^{12}$ The assessment maintained a focus on the Iranian ties, which were meticulously examined through the 'Iranian revolution lenses' that remained predominant in the analysis. Nevertheless, the FCO assured 'the UAE authorities, especially in Dubai, that they maintain close and effective surveillance on those suspected of engaging in subversive activities'. ${ }^{13}$ As far as Kuwait is concerned, the Iranian revolution surely awakened Shi'a self-consciousness; even the Shi'a demonstrations that mostly occurred on Ashura celebrations were not a subject of concern for British and Kuwaiti authorities, as Shi'a mobilization in 1983, as the documents reveal, remained at low level. ${ }^{14}$

Occasionally, religious sectarianism appeared as a Sword of Damocles above the Persian's Gulf security and stability. In particular, Iraq, with the politicization of the Shi'a community-i.e., with the creation of the Hizb al-Da'wa al-Islamiyya already since 1958-and its dynamic religious establishment (Chalcraft 2016, pp. 402-07), was the main concern of the FCO. In fact, FCO documents reveal that British officials were reassuring about the prospect of a Shi'a takeover in Baghdad. P.F.M. Wogan, from the FCO's MED, argues that even if Shi'a came to power, 'any Shi'a regime would be difficult to retain power for long'. ${ }^{15}$ In the eyes of the British, there are underlying differences between the Iraqi Shi'a's and the Iranian Shi'a's, reflecting mostly two variables of the Shi'a in Iraq; namely, their history and social characteristics. In 1983, the British embassy in Baghdad informed the FCO that it is difficult to envisage an Iranian-style Shi'a uprising in Iraq due to the lack of a genuine support from the Shi'a Iraqi side to the ideas of the radical clergy in Iran, since these ideas do not necessarily reflected their social and political aspirations. Therefore, what British officials underlined is the lack of appeal to the ideas of khomeinism in Iraq, even though Khomeini spent several years of exile in Najaf.

The fear of destabilization in countries such as Iraq was related to their importance to the West. In the beginning of the 1980 's, British officials claimed that the threats posed by the Islamic awakening on regional stability could be twofold: the destabilization of key states and the possible rekindling of sectarian feelings in multi-ethnic states. The former includes states such as revolutionary Iran and Egypt. The significance of these countries lies in their political reflection, their size, and their strategic importance for western countries. As far as the likelihood of a deep fragmentation of multi-ethnic states like Iraq is concerned, it was stressed that the rise of peripheral nationalisms could shake the regional political order. In this context, an interesting case study for Britain came from the multi- ethnic Soviet Union and its Muslim components, since during the 1980's, the FCO observed the politicization of Muslim populations with mounting concern. ${ }^{16}$

The assessments regarding Shi'a politicization in Iraq in the first half of the 1980's pointed out that the Iraqi Shi'a clergy could not initiate, let alone sustain, a popular Shi'a mobilization in line with Iran. Especially after the murder by Iraqi authorities of the influential Shi'a spiritual and political leader Baqir al-Sadr in 1980, the Shi'a community in Iraq was much weakened. ${ }^{17}$ In this sense, the foundations for a Shi'a popular uprising are seen as mitigated. In addition, British diplomats in Baghdad were insisting on 'the habit of coexistence' among the Shi'a population. Even though social relations were different in various cities, such as Karbala-with the 1979 riots-or Basra, intercommunal and interfaith dialogue and coexistence predominated in Iraq, according to the FCO. As the British ambassador in Baghdad put it, in 1983, amidst the Iran-Iraq War, the inhabitants of the Shi'a neighborhood of al-Thawra 'are subjected to intensive and clumsy programs of Ba'athist indoctrination', which were not, as he implies, unsuccessful. ${ }^{18}$ For this purpose, as the British embassy reports, the Ba'athist regime

\footnotetext{
BNA, FCO 8/4901, NB 226/2, “Implication of Islamic Sectarianism”, Abu Dhabi to London, 17/4/1983.

BNA, FCO 8/4901, NB 226/2, “Implication of Islamic Sectarianism”, Abu Dhabi to London, 17/4/1983.

BNA, FCO 8/4901, NB 226/2, "Political Implications of Islamic Sectarianism", Kuwait to London, 11/5/1983.

BNA, FCO 8/6504, NB 226/2, “Islamic Fundamentalism in the Gulf”, Wogan to Egerton, 31/8/1983.

BNA, FCO 8/6504, NB 226/2, “The Political Importance of Islam”, Makepeace to Richmond, 9/8/1983.

7 BNA, FCO 8/6504, NB 226/2, "Islamic Sectarianism in the Gulf", Myers to Wogan, 27/6/1983 and JIC Telegram No 583, "Islamic Sectarianism", FM Baghdad 1809900Z, 23/5/1983.

18 BNA, FCO 8/4901, NB 226/2, “Political Implications of Islamic Sectarianism”, Moberly to Egerton, 13/4/1983.
} 
appointed Izzat Ibrahim—vice president of the Revolutionary Command Council—to strengthen the regime's ties with Shi'a communities.

British authorities acknowledge the suffering of the Shi'a under the Saddam Hussein regime, due to a number of factors such as the agrarian reform and the lack of political representation, to name a few. However, Baghdad's policy on prosecution in tandem with the selective and careful incorporation of elements of the Shi'a community in the state apparatus gave the Shi'a a flavor of consent to some extent. This acceptance is not to be underestimated, as the Iraqi people are described by FCO reports as 'Calvinistic' in their approaches of resolving conflicts. This is an attribute that reflects the overwhelming prevalence of material progress over matters of faith for the Iraqi population. ${ }^{19}$

\section{Islamist Organizations and Non-State Actors in a Changing World}

Islamic transnational politics brought to the fore organizations of political Islam, be they Sunni or Shi'a, with which the FCO was preoccupied. Religious sectarianism bred the ground for the creation or the empowerment of parties and non-state actors in order to defend or promote their ideas and interests. Nevertheless, the FCO outlined their divisions, their weaknesses, and their plasticity to adopt in a changing political environment.

In this context, British officials were highly concerned about the role of religious brotherhoods in the 1980's and their social basis. For example, the FCO's attention was directed towards the implications of the Sufi tariqas on Sudanese politics, even though their mentality rejected direct participation in political processes. This view lies on the premise that Sufi tariqas were predominantly rural and thus influenced the development of intellectual activity and lay culture. ${ }^{20}$ In times, the approach of British officials was persistent on the implications of religious sectarianism on MENA. Thus, the analysis was more concerned with the impact that religious sectarian feeling had in social and political relations, rather than on the influence that religious actors had in the political process, per se, as the analysis of Shi'a politics in the early 1980 's Iraq and Syria reveals. ${ }^{21}$

Another important reason for the proliferation of Islamic militancy and militant groups-such as Hamas-was the unresolved and protracted Israeli-Palestinian conflict. British officials stressed emphatically that a solution should undoubtedly include the Palestinian Liberation Organization (PLO). The West's denial in acknowledging PLO as the sole legitimate representative of the Palestinians posed a great threat for British interests for two reasons, as a document reveals. First, it empowers Islamic solidarity feelings among the Palestinians, especially in Gaza and, second, it 'inhibits many Middle Eastern states from moving as close to the West as they would like'. ${ }^{22}$ In regards with British involvement in the issue, most reports underlined the importance of a closer economic relation with MENA countries-given that Britain is less involved in the dispute-but, at the same time, they stressed that London should have 'complementary military role' in the region based on its special relationship with the US. ${ }^{23}$

The rise of religious orientated non-state actors in MENA in the first half of the 1980's saw the endeavor of the global community, including British officials, to engage more closely with the Organization of Islamic Conference (OIC). This occurred in the context of trying to impel 'a common search for solutions to global problems, such as questions related to international peace and security'. ${ }^{24}$ These endeavors emerged in an environment of intensifying violence and security threats, for instance in Lebanon and Egypt. The steps taken for the consolidation of mutual regimes of respect and

19 BNA, FCO 8/4901, NB 226/2, “Political Implications of Islamic Sectarianism”, Moberly to Egerton, 13/4/1983.

20 BNA, NF 226/1, W98C, R.O. Miles (N. East and N. Africa Dept.) to R.A Fyjis-Walker Esq. CMG CVO, (Khartoum), “Islam and Politics", 27/07/1981.

21 BNA, NF 226/1, W98C, Middle East Section Research Department, "Chatham.", Ibid.

22 BNA, FCO 93/2311, NF226/1, "Summary of the Conclusions of the Report of the Islam Study Group", 31/7/1980.

23 BNA, FCO 93/2311, NF226/1, "Summary of the Conclusions of the Report of the Islam Study Group", 31/7/1980.

24 BNA, FCO 58/2759, UNPO22/33, "Cooperation between UN and the Organization of African Unity, Organization of Islamic Conference and League of Arab States", Nash to Roberts and Williams, 29/11/1982. 
cooperation developed at the same time in MENA countries themselves, given that the latter were trying to delegitimize Islamic opposition groups and manipulate the official religious establishment (Esposito et al. 2016, p. 203).

In this process, the FCO's diplomatic circles made efforts on reporting on the issues of Islamic fundamentalism and forms of extremism in a number of countries. In 1978, C.D. Powell from NENAD reported on M.B. in Egypt that despite its semi-legal form, it had 'cultivated a respectable image', while' as he continued, it was 'recruiting successfully particularly at the universities (their magazine [al Da'wa with senior editor the M.B. spiritual murshid Omar al-Tilimsani] allegedly has eighty thousand readers) ${ }^{\prime}{ }^{25}$ The organization's success was also attributed to its energetic leadership, good political organization and its adequate sponsorship.

The FCO also kept a close eye on the Levant. Syria is an example of small yet fast rising Islamic extremism detected since 1978 among the younger educated Sunni middle class. ${ }^{26}$ In 1986 , four years after the bloody eradication of the Syrian branch of M.B. in Syria, the British embassy in Damascus reported that it is of an extremely high risk to get contacts with Islamist networks, since the Assad regime had enforced severe restrictions on Islamist mobilization. These constrains left little space for political maneuvering, according to British diplomats. Furthermore, regarding the small Shi'a community in Syria, the FCO cast doubts on its radicalization in the mid 1980's for mainly two reasons. The first one relates to its small number (perhaps 20,000 in 1986). The second one was the regional alliance between Iran and Syria. Tehran, as British ambassador in Damascus W. R. Tomkys stresses, did not want to destabilize her close ally Assad for the sake of an Iranian-style Shi'a activism. ${ }^{27}$

Tomkys dedicates a meticulous description of the Syrian M.B. and its founding principles, which are based on Islamic activism, solidarity, and opposition to the 'infidel' Alawi Ba'athist state. Tomkys underlines the importance of two basic Brotherhood targets that are important for the FCO's perception of political Islam. On the one hand, he stresses the importance for the Islamic movement regarding the abolition of the sectarian system and their aspirations of political liberalization. This could allow the Islamist movement to freely form legal political parties and bid for political power. The other variable is their aspiration for economic liberalization. Tomkys assesses that this is the voice of Sunni merchants', ${ }^{28}$ since the Syrian Sunni merchants were looking for channels to invest their accumulated capital. Economic liberalization could be achieved through a combination of political openings that could create political opportunity structures and a wide banking reform that could facilitate their social and economic position. Thus, Tomkys affirms the position of a political Islam with social and political aspirations that seeks to reap the benefits of modernization:

It is not strictly accurate to view the Sunni mujjahideen as solely dedicated to destroying the system. [ ... ] In many respects their political program embodied a call for a return to traditional elements of the Syrian political system. [ .. ] Land-owners, merchants, professionals, Allepines and Hamawis, certain grandes families-in short most of the elements of the traditional Sunni hierarchy-were offended by changes being wrought at the hands of the Alawi neo-Ba'athists. ${ }^{29}$

Nevertheless, given the divisions and the ideological conflicts between Brotherhood fractions-i.e., the Damascus-Hama dispute (Pargeter 2013, pp. 75-90)—the FCO's assessment is rather reassuring about the likelihood of an Islamist takeover. On top of it, the Syrian regime followed the respective policy of other Arab regimes, giving vocal support to established moderate Sunni leadership. As the

25 BNA, FCO 93/4048, NF 031/1, “Islamic Fundamentalism”, Powell to Bannerman, 22/9/1978.

26 BNA, FCO 93/4048, NF 031/1, "Islamic Fundamentalism", Powell to Bannerman, 22/9/1978.

27 BNA, FCO 93/4755, NFy 226/1, "Islamic fundamentalism in Syria", W.R. Tomkys to J.P. Bannerman, 10/1/1986. The same applies to British foreign policy as any attempts from the Embassy's side to cultivate links with Islamist circles is "out of question" since this would anger Damascus.

28 BNA, FCO 93/4755, NFy 226/1, "Islamic fundamentalism in Syria”, W.R. Tomkys to J.P. Bannerman, 10/1/1986.

29 BNA, FCO 93/4755, NFy 226/1, “Islamic fundamentalism in Syria”, W.R. Tomkys to J.P. Bannerman, 10/1/1986. 
documents show, the same stance applies to the Jordanian paradigm. In 1986, the correspondence of the British embassy in Amman marks Zaid Rifa'i's—-the Jordanian Prime Minister-position on the Jordanian Muslim Brotherhood. The correspondence states the prevalence of moderate ideas in the country, reporting that 'the country was too sophisticated and too cosmopolitan to be swayed by fundamentalist ideas'. ${ }^{30}$

The plasticity of the groups of political Islam is backed by the FCO with the distinction of its manifestations to the 'extremists', who ascribe to militant means, and to the 'activists', who comprise of peaceful groupings. The term fundamentalism, however, should not be used as it creates 'misconceptions' that are usually linked to Shi'a activism, as stated by British diplomats. International relations, as an FCO background brief in 1990 puts it, are highly influenced by the militant Islamic element in Iran's foreign policy. This tendency 'has led the country [Iran] to act outside accepted international norms, notably by promoting the export of the revolution through violence, and has given her policy a pronounced anti-western bias', the FCO states. ${ }^{31}$

Again, the rising tide of non- state actors and organizations, like Hizbollah, and the implications on stability are reflected in a number of FCO documents. For example, in an attempt to approach Shi'a mobilization and its position on the concept of violence, the FCO circulated a translated article written by Muhammad Hussein Fadlallah, Hizbollah's spiritual leader in the 1980's, who tried to conceptualize the idea of Shi'a politics and transnational violence. In his article, Fadlallah promotes the rhetoric of peaceful conflict resolutions but makes clear that when peaceful means are exhausted then 'violence as surgical operation' should follow. ${ }^{32}$ The Lebanese leader continues by aggregating that the root of the Middle East violence lies in the unresolved Palestinian question, something the FCO partly admits. 'Violence', Fadlallah asserts, 'erupted in the region with the birth of the state of Israel' ${ }^{33}$

In 1990, the FCO emphasized the fact that the Iranian revolution was still trying to promote its messages, aspirations and support to other Islamic countries and organizations. Hizbollah was a bright example. The Lebanese group is described as the 'leading pro-Iranian fundamentalist organization' that managed to bloom because the Iranian revolution acted both as a model and a political and financial sponsor (Daher 2016, pp. 26-34). However, the FCO's analysis of 1990 failed to see the growing Shi'a political mobilization in Iraq. It predicted wide resentment among the Shi'a's due to their exclusion from power sharing:

There is little effective opposition, secular or Shi'ite, to the regime. There is also little evidence of unrest among Iraq's Shi'ite troops, who have been fighting their co-religionists in the Iran/Iraq conflict. ${ }^{34}$

For NENAD, religious sectarianism and loyalties depending on religious denomination were the subject at stake for the period on which we focus. What the FCO underlines is that religious denomination plays the same important role as social, economic, and political factors. The transformation of diplomatic discourse towards religious sectarianism at the end of the 1970's is revealed by a number of documents that stress the emergence and the influence that religious parties or organizations have at a global level. For this reason, NENAD supports that a high priority should be given to religious politics and their representatives:

Contacts with religious bodies and specialist organizations must be judged on their merits.

[... ] Where the political and social structure includes a strong religious element, we give

\footnotetext{
BNA, FCO 93/4558, NF 245/2, “Jordan: Islamic Fundamentalism”, Coles to Bannerman, 5/2/1986

BNA, FO 973/624, "Islamic Resurgence", Background Brief, April 1990.

BNA, FCO 8/6120, NB 226/3, "Islam and Violence in Political Reality" Lamb to Boyce, 8/5/1986.

BNA, FCO 8/6120, NB 226/3, "Islam and Violence in Political Reality" Lamb to Boyce, 8/5/1986.

BNA, FO 973/624, "Islamic ... ", Ibid.
} 
priority to it. [ ... ] In the Middle East intelligent ecclesiastical visitors with the feel of the region are very welcome to embassies. ${ }^{35}$

\section{The 'Watermelon' Fear: Political Islam and the Left Against Imperialism}

The third analytic point is highly connected with the context of the Cold War and the struggle against communism. This approach embraces strategic concepts of orientation and reads the likelihood of an alliance between political Islam and the Left as a genuine menace. Even though the possible survival of such an edifice was not likely, according to the FCO, what overwhelmed the analysis is the fear that occurred from the vacuum that the weakening of the Arab nationalist camp created in the Cold War period.

British foreign policy makers were at times deeply concerned about the alliance of leftist and Islamist movements, given their enmity towards Arab-Muslim secular dictatorships. Especially with the outbreak of the Iranian revolution, western governments were alarmed by the prospect of a bridging between militant Marxist and Islamist movements in the country and elsewhere. Nevertheless, from an early stage, Britain itself promoted the idea of collaboration with Islamist movements in order to safeguard the country's interests. For instance, as early as 1952, the British embassy in Tehran envisioned an alliance with the Islamists of Fedayan-e Islam. ${ }^{36}$ Fedayan, founded by N. Safavi in 1946, played an important role in forging an opposition to Mossadeq, whom the British despised for his nationalization policies. ${ }^{37}$

Given the dynamics unleashed from the Iranian revolution in 1979, the likelihood of a leftist-Islamic alliance posed a grave threat to British diplomatic cadres. Indeed, since 1979, Islamist and Marxist movements in Iran, such as the Tudeh or the Fedayeen e-Khalq, cooperated with Khomeini in order to establish a revolutionary government. As mentioned by the FCO Study Group of Islam (SGI) in 1980, 'until recently socialist and communists [ . . . ] in the Middle East have sought to further their causes through the forces of secular Arab nationalism'. ${ }^{38}$ Notwithstanding, the convergence of the cause between socialists and communists could pave the ground for a menacing alliance against the secular political establishment in the region. But given that the latter had lost much of its appeal to the Arabs, the Left, as the FCO mentions, was trying to approach the Islamic movements. However, as the Study Group of Islam assesses:

This can never be more than an uneasy and temporary alliance. Islam cannot coexist happily with Marxist materialism any more than communists can readily accept the teachings of the Koran. ${ }^{39}$

Western interests could also be affected by the prospect of a Marxist-Islamist alliance. As NENAD points out, implications on stability could occur 'when Muslim extremist organizations are infiltrated by or form tactical alliances with, communism in situations of serious unrest' as was the case with Iran. ${ }^{40}$ Even though British diplomats predicted that such an alliance could not be forged, they paid attention to the fact that:

When expediency demands they are prepared to emphasize the principles of egalitarianism and social welfare which Islam and communism share and to ignore the atheism of the communist creed. ${ }^{41}$

\footnotetext{
BNA, FCO 8/4901, NB 226/2, “The Religious Factor in Contemporary Politics, Miles to John, 17/3/1983.

6 BNA, FO 248/1540, G 10141, “Fiday'ian-i-Islam”, R.C. Zaehner, 1/3/1952.

37 Specifically, the ambassador R. C. Zaehner thought that the keyperson to bring them in contact with the Fedayan was Sayeed Zia, the leader of the Homeland Party who believed Britain was the least evil in comparison to Mossadeq and the Americans. Ibid.

38 BNA, FCO 93/2311, NF226/1, "Report of the Islam Study Group", 31/7/1980.

39 BNA, FCO 93/2311, NF226/1, "Report of the Islam Study Group", 31/7/1980.

40 BNA, FCO 93/4048, "The Islamic Revival, Development and Western Interests", November 1978

41 BNA, FCO 93/4048, "The Islamic Revival, Development and Western Interests", November 1978.
} 
In addition, the British embassy in Washington clearly manifested the American position in 1979 regarding the interrelation between Marxist and Islamist movements. The former's stimulus to 'use to their own political advantage the anti-western manifestations of Islamic revival movements' ${ }^{42}$ Nonetheless, communications between the two movements, as these were portrayed by the FCO, were poor, 'reflecting their mutual distrust'. However, what the FCO detects is the Left's growing interest in seeking a dialogue with the Islamic trend (Abdelrahman 2009, p. 38). ${ }^{43}$

\section{Islam as a Culture and Islam as a Political Ideology}

The last field of focus of the FCO concerned issues of cultural exceptionalism. This approach maintains the indiscernible relation of religion and politics in Islam and the absence of a respective Enlightenment. This point focuses on the issue of cultural exceptionalism in the Middle East, based on anti-western feelings due to colonial heritage. The FCO's analysis underlines the Muslim perception of the secular state and modernization as a western malign imposition, which cultivates strong feelings of Islamic solidarity.

Islamic solidarity, as British diplomats assert, though deep rooted in the Islamic world, was reintroduced by the shocking waves of the $1967 \mathrm{Al}$-Naqsa (the Arab defeat). The defeat and its impacts -as they have been described in a moving way by Syrian philosopher Sadiq al-Azm (al-Azm 2012) -marked the demise of the actual resonance of Nasserist pan-Arabism. The defeat was often portrayed as a divine punishment for abandoning Islam. Thus, the Islamic feeling mushroomed and curved the way for an all-out assault to its secular counterparts. The concept of Islamic solidarity further paved the way to focus on whether an idea of Islamic foreign policy exists. In general, the definition of 'Islamic foreign policy' is disorientating. Nevertheless, British officials defined it as a common set of values and strategies based on Islamic interests. The political and structural motives in the awakening of Islam were constantly underlined. As P.F.M. Wogan of the FCO Middle East Department put it in 1983:

It was not piety that created revolutionary Iran, but political ruthlessness and an astute awareness of how to mobilize people. Even Ayatollah Khomeini was respected primarily for his political opposition to the Shah. [... ] The appeal of fundamentalism [ ... ] provides, through Islam, a legitimate means of articulation opposition to existing society and to the import of foreign values. ${ }^{44}$

Concerns about Islamic solidarity were also manifested in King's Hussein proposal in 1978 of establishing an Islamic Commonwealth. This Commonwealth was seen as a facet of Islamic revivalism, which had some implications on British and European interests. Nevertheless, given the political and doctrinal divisions among Islamic countries and the differentiations in regional interests, the FCO predicted that King's Hussein idea would likely have little success, as it eventually did. ${ }^{45}$ However, the idea of the Islamic Commonwealth as a stabilizing factor and as a 'moderating influence on the fanatical elements' was also expressed. ${ }^{46}$

Nevertheless, the persistence of engaging with Islam had two further sources: first, the reaction to rapid and disruptive modernization, and second, the quest for a spiritual haven escaping from western materialism. Modernization in the historical conjuncture of the 1970's and 1980's was perceived as a tool for integration in the developed-world system. However, it was not only viewed in economic terms. Modernization was also a measure for adapting in political and socially accepted patterns as the work of S. Huntington has shown (Huntington 1968; Bill and Leiden 1979, p. 69). Disruptive

42 BNA, FCO 93/1837, NF 2261/1, “The New Islamic Fundamentalism”, Muir to Tatham, 28/2/1979.

43 BNA, FCO 93/1837, NF 2261/1, "The New Islamic Fundamentalism", Muir to Tatham, 28/2/1979.

44 BNA, FCO 8/4901, NB 226/2, “The Religious Factor in Contemporary Politics, Wogan to John, 21/3/1983.

45 BNA, FCO 93/2311, "Islamic Revival”, Tomkys to Weir, 30/11/1978.

46 BNA, FCO 93/4048, NF 031/1, "Islam", Tomkys to Crowe, 15/9/1978. 
modernization ushered Muslims 'to turn to ancient symbols and rites', the FCO claims, and 'in this confusion the only safe mooring seemed to be in the attachment to Islamic values'. ${ }^{47}$ Yet:

The Islamic backlash, then, was not because modernization per se is unacceptable to Muslims but, rather, because the effects of the modernization program were unacceptable. ${ }^{48}$

Hence, what the FCO accentuates is rather a gingerly endeavor by Muslims to cope with modernization. However, despite the remaining presence of a strong bias against a progressive Islam during the 1980's, several intellectuals observed the mistaken oversimplification of the interaction of religion with economic development (Eickelman and Piscatori 1996, pp. 23-24). The anomic consequences of development in MENA made political Islam attractive in the years following the Iranian revolution. Even though there was not a pragmatic consensus about how an Islamic model of political organization should look like, it seemed that a wide majority of Muslims believed that Islam should be part of the 'nativized' solution. This search for the native identity emphasized on the traditional networks of Islamic society, such as family and clan, solid networks that the great Arab historian Ibn Khaldun described as assabiyya.

In tandem, cultural exceptionalism is expressed in many different ways. Nevertheless, the main reflections of this position postulate the religious specificity of the Arab-Muslim world, since religiosity is seen as an integral part of various identities. Since Islam was perceived as a dynamic intellectual, social, and political phenomenon, the FCO specialists observed that the readings concerning Islam should not remain monolithic. This point is important because Islamic religion was often portrayed as anti-western and anti-Christian. 'In this situation where various Islamic ideologies mix with specific national interests, it is unlikely' an FCO assessment states, 'that we will find Muslim statesmen whose overriding ambition is to push back the frontiers of the Christian West' ${ }^{\prime} 9$ This position reflects the acknowledgement of the renegotiation by Muslims of key-concepts, such as modernity, postmodernity, and the West, leading to alternative contextualization of Muslim identities.

Islamic assertiveness, the FCO underlines-adopting M. Yapp's position-lies deep in the process of the encounter between European colonialism in the period of modernization and various forms of Islamic civilizations. The Islamic world adopted in general facets of modernization but, to a great extent, the process of modernization was confined to political and economic elites, as was also the European paradigm. One facet of disruptive modernization, as seen from London's view, is crystallized in hectic urbanization. ${ }^{50}$ Family and denominational/community networks became gradually more important in the process of urbanization. While alternative identities where galvanized in order to take part in the political process, Muslim identity was consolidated. In fact, as modernization further proceeds, all the more people are dragged into the towns and its industrial suburbs, as in the case of Cairo and Tehran, triggering a wide gap between the elites and lower social strata, which, as many people assert, is equated with the betrayal of core Islamic values.

\section{Conclusions}

Overall, whether British officials regarded political Islam as a menacing phenomenon or not, it is evident that the FCO paid great attention to its emergence. Many of the studied documents repeatedly stress the need to focus on British interests and implications on foreign policy, but also on the need to adhere to the concepts of tolerance and understanding (Rynhold and Spyer 2007, p.138). ${ }^{51}$ It is evident that although the FCO gradually adopted a securitization discourse-which was also consistent with state policies-it also preserved some autonomy upon its analytical approach (Rynhold and Spyer 2007,

47 BNA, FCO 8/6504, NB 226/2, “The Political ... ", Ibid.

48 BNA, FCO 8/6504, NB 226/2, "The Political ... ", Ibid.

BNA, FCO 8/6504, NB 226/2, "The Political ... ", Ibid.

BNA, FCO 93/2311, “Contemporary Islamic Revivalism: A Discussion Panel”, 12/2/1980.

BNA, FCO 8/6120, NF 226/3, "Research on Islam", Long to Bannerman, 5/12/1986. 
p. 141). We do not argue that the dominant effect of Britain's 'global role' was absent at the FCO. However, the debates and controversies between British officials regarding the character and the role of political Islam were always vibrant.

British officials sometimes fell short when it came to transcending the traditional discourse of power influence and its connection to sectarian kinship regarding MENA (Mabon and Wastnidge 2019, p. 596). However, even though the British diplomatic authorities feared the influence of the 1979 Iranian revolution and the spread of political Islam and Shi'a mobilization, they did not read Islamist feelings in a bandwagon manner. Instead, they articulated their predictions and their perspectives by using historical, social, political, and economic tools that that enabled them to weigh the balance of power, even though at times—-for example in the Kurdish and Shi'a uprising in Iraq in 1991—-they failed to acknowledge the dynamics. Nevertheless, as our archival material reveals, sometimes, the FCO could not escape from the use of stereotypical approaches that failed to see the historical driving forces.

Funding: This research received no external funding.

Conflicts of Interest: The author declares no conflict of interest.

\section{References}

\section{Archival Material}

British National Archives: NF 226/1, FCO 93/4048, FCO 8/3419, FCO 8/6504, FCO 8/4901, CO 93/2311, FCO 58/2759, FCO 93/4755, FCO 93/4558, FO 973/624, FCO 8/6120, FO 248/1540, FCO 93/1837, FCO 8/6120.

People's History Museum: CPGB Archive, CP/CENT/INT/56/03.

\section{Published Sources}

Abdelrahman, Maha. 2009. 'With the Islamists?-Sometimes. With the State?-Never!' Cooperation between the Left and Islamists in Egypt. British Journal of Middle Eastern Studies 36: 37-54. [CrossRef]

al-Azm, Sadiq. 2012. Self-Criticism after the Defeat. London: Saqi Books.

Aslani, Iman. 2020. Britain Complicit in the Crushing of Iran's Tudeh Party. Qantara. February 5. Available online: https://en.qantara.de/content/at-khomeinis-service-britain-complicit-in-the-crushing-of-irans-tudehparty (accessed on 26 February 2020).

Omer, Atalia. n.d. Religion and Nationalism: What is the Link? In Religion and International Relations: A Primer for Research. (Working Group on International Relations and Religion). Indiana: University of Notre Dame, pp. 111-32.

Bill, James A. 1989. Populist Islam and U.S. Foreign Policy. SAIS Review 9: 125-39. [CrossRef]

Bill, James A., and Carl Leiden. 1979. Politics in the Middle East. Boston and Toronto: Little Brown.

Callaghan, John. 2007. The Labour Party and Foreign Policy: A History. Abingdon: Routledge, p. 211.

Çavuşoğlu, Esra. 2018. Britain's Post-Colonial Foreign Policy Towards Persian Gulf Security (1971-1991): An Alternative Approach. Turkish Journal of Middle Eastern Studies 5: 37-64.

Chalcraft, John. 2016. Popular Politics in the Making of the Modern Middle East. Cambridge: Cambridge University Press, pp. 402-7.

Daher, Joseph. 2016. Hezbollah: The Political Economy of Lebanon's Party of God. London: Pluto Press, pp. 26-34.

Dunne, Tim. 1999. A British School of International Relations. In The British Study of Politics in the 20th Century. Oxford: Oxford University Press, pp. 395-99.

Eickelman, Dale, and James Piscatori. 1996. Muslim Politics. Princeton: Princeton University Press.

Esposito, John, Tamara Sonn, and John O. Voll. 2016. Islam and Democracy after the Arab Spring. Oxford: Oxford University Press, p. 203.

Fowkes, Ben, and Bülent Gökay. 2009. Unholy Alliance: Muslims and Communists-An Introduction. Journal of Communist Studies and Transition Politics 25: 1-31. [CrossRef]

Fox, Jonathan. 2009. Integrating religion into international relations theory. In Routledge Handbook of Religion and Politics. Edited by Jeffrey Haynes. Abingdon: Routledge, pp. 277-79.

Garnett, Mark, and Philip Lynch. 2009. Exploring British Politics. Essex: Pearson Education Limited. 
Hall, Ian. 2014. Martn Wight, Western Values, and the Whig Tradition of International Thought. The International History Review 36: 961-81. [CrossRef]

Hamid, Sadek. 2018. Sufis, Salafis and Islamists: The contested Ground of British Islamic Activism. London: I.B. Tauris. Huntington, Samuel. 1968. Political Order in Changing Societies. New Haven and London: Yale University Press.

Kemper, Michael. 2009. The Soviet Discourse on the Origin and Class Character of Islam, 1923-1933. Die Welt des Islams 49: 1-48. [CrossRef]

Hasler, Kirstin. n.d. International Relations Theory and Nationalism: Any Room for Religion. In Religion and International Relations: A Primer for Research. (Working Group on International Relations and Religion). Indiana: University of Notre Dame, pp. 133-41.

Mabon, Simon, and Edward Wastnidge. 2019. Transnational religious networks and geopolitics in the Muslim World. Global Discourse 9: 593-603. [CrossRef]

Maghraoui, Abdeslam M. 2006. American Foreign Policy and Islamic Renewal. Connections 5: 26-40. [CrossRef] Mandaville, Peter. 2001. Transnational Muslim Politics: Reimagining the Umma. London and New York: Routledge. Mayhew, Christopher. 1950. British Foreign Policy Since 1945. International Affairs (Royal Institute of International Affairs 1944-) 26: 477-86. [CrossRef]

Pargeter, Alison. 2013. The Muslim Brotherhood: From Opposition to Power. London: Saqi Books, pp. 75-90.

Rynhold, Jonathan, and Jonathan Spyer. 2007. British Policy in the Arab-Israeli Arena 1973-2004. British Journal of Middle Eastern Studies 34: 137-55. [CrossRef]

Taylor, Charles. 2007. A Secular Age. Cambridge: The Belknap Press of Harvard University Press, pp. 1-24.

Thomas, M. Scott. 2001. Faith, History and Martin Wight: The Role of Religion in the Historical Sociology of the English School of International Relations. International Affairs (Royal Institute of International Affairs 1944-) 77: 905-29.

Vaughan, James. 2005. A Certain Idea of Britain': British Cultural Diplomacy in the Middle East. Contemporary British History 19: 151-68. [CrossRef]

Wood, Neal. 1978. The Social History of Political Theory. Political Theory 6: 345-67. [CrossRef]

(C) 2020 by the author. Licensee MDPI, Basel, Switzerland. This article is an open access article distributed under the terms and conditions of the Creative Commons Attribution (CC BY) license (http://creativecommons.org/licenses/by/4.0/). 
Article

\title{
A Theory on the Involvement of Religion in National Security Policy Formulation and Implementation: The Case of Israel before and after the Religionization of Its Security Environment
}

\author{
Moria Bar-Maoz \\ Department of Political Studies, Bar-Ilan University; Ramat Gan 5290002, Israel; moria.bar-maoz@biu.ac.il
}

Received: 4 March 2020; Accepted: 29 April 2020; Published: 4 May 2020

\begin{abstract}
This article offers, for the first time, a theoretical model of religion's influence on the formulation and execution of national security policies. To build this model, it analyses the influence of religion on Israel's national security policymaking-before and after Israel's security environment went through a process of religionization beginning in the 1970s. The article proposes that religion's effect on national security policymaking is comprised of three tiers that follow one another in the decision making sequence and, yet, are independent from one another: (1) operational beliefs embedded in the state's security thinking on the relations between religion and security; (2) opportunities and constraints on the state's freedom of action, due to the role religion plays in global, regional and domestic politics as well as bilateral relations; and (3) governmental utilization of religion to realize national security goals. At its conclusion, the article demonstrates that the model is applicable to other countries as well, using the case of France's policies in the 21st century.
\end{abstract}

Keywords: national security; religion; Israel; Middle East; Islam; Judaism; France

\section{Introduction}

The belief in a close connection between national security and religion is quickly becoming the new gospel of the International Relations discipline. However, so far, the growing body of literature on religion and national security has not yet provided us with any theory on how religion influences the formulation and implementation of national security strategy (Sieple et al. 2013; Shaw 2011; Lucius 2013; Seiple and Hoover 2004; Farr 2008; Thomas 2010; Hassner 2009, 2013, 2016; Rubin 2014; Bar-Maoz 2018). To advance the process of theorization, this article offers a model of how religion influences the formulation and execution of national security policies, using the case of Israel's national security policies throughout its history.

On the issue of religion and national security, Israel is an ideal case to generalize from because it provides the researcher with a longer than average period of time in which policymakers strategized over religious matters. Israel's decisionmakers incorporated thinking about religion into its national security doctrine from the very inception of the state in 1948, unlike many other countries which did not do so prior to the 21st century. The time period of the Israeli case is also conveniently demarcated halfway through, in the late 1970s, by the religionization of the country's environment, enabling the detection of patterns of continuity or change in the way a country in pursuit of national security approaches religion, when its environment shifts from mostly secular to mostly religious. The process of theory development is also assisted by the greater than average number of connections existing in Israel between religion and national security—none of them so unique they are not found elsewhere, as the article's last section shows.

On the other hand, the fact that the majority religion of Israel, Judaism, is both a nationality and a religion can be a potential problem when generalizing from the Israeli case to others. To circumvent this 
problem, the analysis in this article includes only national security policies having a clear "religious" undertone: policies that were guided by assumptions on religious matters, that signified a serious attempt to utilize religion for security objectives, or that pushed decisionmakers towards perceiving religious actors differently than secular actors. It therefore excludes, for example, the extension of the state's protection to Jews everywhere-a basic principle of Israel's security policy-because the relationship between Israel and the Jewish diasporas more closely resembles the relationships of other countries with their ethnic and national diasporas, rather than with their religious diasporas. With the exception of assisting in the protection of synagogues abroad, as they are a favorite target of anti-Semitic and Islamic attacks, Israel does not fund or support the religious lives of Jews abroad, unlike many countries that support the religious lives of diasporas of their own religion (Mandaville and Hamid 2018; Çitak 2010; Ahmed 2012). Excluding the nonreligious aspects of Israel's "Jewish" national security policy enables the development of a model of the relation between religion and national security that can be applied to polities where there is no overlap between religion and nationality.

The article begins with an exploration of how young Israel understood the connection between religion and national security. Then it explores how, after the 1970s, Israel's conflict with its environment transformed from a secular, nationalist inter-state conflict into a conflict between two religions, and how this transformation influenced the role religion plays in formulating Israel's national security strategy today. From its comparison of the periods before and after the region's religionization, the article constructs a model for the analysis of religion's impact on the formulation and implementation of national security policies. The model proposes that religion's effect on national security policymaking is comprised of three tiers: (1) operational beliefs embedded in the state's security thinking on the relations between religion and security; (2) opportunities and constraints on the state's freedom of action due the role religion plays in global regional and domestic politics, as well as bilateral relations, and (3) how the state utilizes religious actors, organizations, symbols and rhetoric in the instruments of national power, in order to achieve policy goals. At its conclusion, the article demonstrates that this model is applicable to other countries as well, using the case of France's policies in the 21st century.

The proposed model relies upon the literature on national security formulation and implementation, such as the writings of Luttwak (1976), Gray (1982, 2016), Redd and Mintz (2013), Snow (2011), Drew and Snow (2006). It also relies upon the theories of foreign policy decision-making of Brecher et al. (1969), and of McGowan and Shapiro (1973). Because the article focuses on decisionmakers' perceptions, in the section analyzing the Israeli approach, the terms used for places and events are the Israeli terms rather than the Arab or Palestinian terms (i.e., "Temple Mount" rather than "Haram al-Sharif", the "Second Intifada" rather than the "Al-Aqsa Intifada", the "territories" rather than the "occupied territories", etc.) An exception is made when the perceptions of non-Israelis are discussed; there, the article uses their own terms. As for the term "religionization", it is used in this article not in the narrow sense associated with it today in Israel, but, rather, in the broad academic meaning that denotes either "a broad range of phenomena in which the religious element expands in private and public lives" (Fischer 2015, p. 12 note 2), or any consistent expansion of the religious element-both meanings not naming the cause behind this expansion. In current Israeli discourse, on the other hand, "religionization" (in Hebrew, hadata) is synonymous with only one type of such expansion, that is, one caused by a deliberate attempt by religious groups to convert a secular lifestyle into a religious one, due to a series of reports in Israeli media in 2010 which popularized this little-known academic term to describe an eminent danger to Israel's secular public space from intentional and organized pressures by domestic religious Jewish groups. Attempts by religious groups to enhance public piety are only one of three types of contributors to religionization, in Israel and in the world (Maniv and Benziman 2020, pp. 119-20); the other two are the organized use of religious symbols, tradition and heritage by religious or nonreligious actors to promote national interests, and "passive" contributors to greater personal or collective religiosity, such as faultline security events, like the 1967 War, that, as will be discussed later, had an extensive impact on the religiosity of Jews, Muslims 
and Christians around the world. Singling out one type of contributor to the exclusion of others is ill-advised, because in most cases of significant religionization of societies, states and regions, all three types come into play, as has been the case in the religionization of Israel's security environment during the last four decades-which is used here to answer the article's main question: What is the role of religion in the making of national security strategy, and does it change with the shifts in religion's place in a country's security environment?

\section{Religion in Israel's National Security Policy: The Early Years}

Israeli decisionmakers have always been painfully aware that Israel's security challenges are shaped, first and foremost, by the religious, ideological hostility characterizing its external environment. How much young Israel took into account religious factors, such as other countries' religious affiliations and religious policies, can be seen in an analysis presented by Israel's founding father and first Prime Minister, David Ben-Gurion, to the Supreme Command of the Israel Defense Forces (IDF) on 2 July 1955 :

Our situation in the world is this: there is one world bloc which seeks to destroy us, and that is the bloc of Arab nations. There is a second bloc that is not prepared to destroy us, but is prepared to assist the Arab nations in their war against us, and that is most of the Islamic nations. And there is a third bloc which has nothing against us, but for various reasons, does not want to recognize our existence. A nation like India ... And there is a fourth bloc that acknowledges the State of Israel, but does not acknowledge the existence of the Jewish people-and this is the Communist bloc [due to its anti-religion policy]. And there is a fifth bloc that acknowledges the State of Israel, does not negate the existence of the Jewish people, although it does not care whether it exists or not, and that is all the rest. (Bialer 1987, p. 148)

At the same time, as this analysis shows, neither religious actors nor religious dogmas were considered threats to Israel's security as much as the secular Arab nation-states were. As Ben-Gurion noted, "most of the Islamic nations" were not prepared to destroy Israel, and some were not even willing to help the Arab world to do so-a strategic difference between the Arab world and the Muslim world which young Israel concluded it would be expedient to exploit. This is the first of three operational beliefs on the link between religion and security held by early Israel's leadership, which shaped the national security strategy Ben-Gurion formulated in the late 1940s and early 1950s to defeat Arab nationalism.

2.1. The First Operational Belief: Young Israel Assessed Religion as a Secondary Source for Both the Arab States and the Non-Arab Actors in the Middle East

Ben-Gurion and his contemporaries viewed the existence of a religious difference between Jewish Israelis and Muslim and Christian Arabs as one source of the Arab ideological hostility to Israel, but not as the main source (see, for example, the Israeli strategist, Yigal Allon 1990, p. 284). While the Arab resistance to the Jewish Yeshuv in the 1920s and early 1930s had a pronounced religious idiom, the religious component in the Arab resistance to the idea of a Jewish state diminished as Arab nationalism was cemented into secular Arab nation-states during the late 1930s and the 1940s. The Israeli leadership was aware that religion was not at the center of the self-definition of Arab nationalism, which sought to unite the Arabs - Christian and Muslims, secular and religious-under the motto "Religion is for God and the homeland is for all of us" (Cohen 2003, p. 349; Litvak 1998, pp. 148-49). When the Arab states went to war with the soon-to-be-established Israeli state in late 1947, almost no Islamic movements chose to join them (Milton-Edwards 2006, p. 76). In the first two decades of Israel's existence, the Arab world defined its conflict with Israel as a secular struggle between Pan-Arab nationalism and Zionism, using the terminology of leftist ideologies to portray Israel as "a bridgehead of western imperialism, designed to splinter Arab territorial integrity and prevent Arab unity" (Litvak 1998, p. 148). 
As to the non-Arab Muslim countries of the region, young Israel judged their religious hostility as genuine but secondary to their strategic interests. In light of Ben-Gurion's understanding that some non-Arab Muslim nations and religious minorities in the Middle East perceived Arab nationalism as a far more threatening phenomenon to their security than a Jewish state, he concluded that his enemy's enemy could still be his ad hoc ally, despite its religious animosity. This conclusion evolved into the periphery doctrine, a major pillar of young Israel's counter-campaign against the Arab threat. Under the doctrine, Israel fostered security cooperation with every non-Arab state and religious minority willing to cooperate with Israel: the secular Shah regime of Persian Iran, the anti-Islam Kemalist regime of Turkey, the Christian regime of Ethiopia, the Kurdish minority in Iraq and the Christians in Sudan (Freilich 2018, p. 257; Inbar 2008, p. 158). The only attempts by a religious minority to tie itself to the young Israel that the latter rejected were those of the Lebanese Maronite Christians-but not because of any ideological opposition. Israel evaluated them as too divided from within to be an effective ally, and was expecting Israel to do the work for them of expelling the Muslims from Lebanon. Furthermore, should Israel fail to do so, they would be the first to turn against it (Bialer 2006, p. 257).

\subsection{The Second Operational Belief: Young Israel Saw Securing the Existence of a Jewish-Majority State a} "Survival Interest" which Trampled Religious Linkage to Sacred Sites

Just as the leaders of young Israel considered the other side's religiosity as secondary to the latter's national interests, so did they consider the religion of their own country as secondary to their own national security considerations. Notably, they prioritized ensuring the survival of a Jewish-majority state over linkage to the sites in the Land of Israel that were sacred to Jews. In 1937, Ben-Gurion pressured the Zionist leadership to announce its agreement to the partition plan proposed by the British Peel Commission, even though it excluded from the Jewish part portions of the historical land of Israel, such as Jerusalem, Judea and Samaria (not to mention the Transjordanian part of the land). This was because Ben-Gurion prioritized the immediate establishment of a sovereign Jewish state, which would provide shelter to European Jews already prosecuted by the Nazis. In his calculation, Israeli control over Jerusalem was improbable to begin with, due to the firm opposition of the Christian world, like the Islamic world, to the idea of Jewish control over sites sacred to other religions, which abound in Jerusalem (Sandler 2007, p. 353; Bialer 2006, pp. 34-38).

Similarly, in the later stages of the 1948 war, it was militarily possible to conquer Judea, Samaria and the Old City of Jerusalem; however, the Israeli government voted against it—on the grounds that the security cost of controlling territories heavy populated by Arabs would damage the ability of the young state to defend itself and absorb immigration. Furthermore, the Jewish conquest of the Old City of Jerusalem with its holy sites would generate international pressure on Israel to withdraw from all of Jerusalem, including western Jerusalem, where Israel had established the seat of its government (Sandler 2007, p. 353). These assessments continued to inform the negative value subsequent Israeli governments placed on the option of conquering Judea, Samaria and the Old City of Jerusalem until May 1967 (Bar-On 2018, p. 12).

\subsection{The Third Operational Belief: The IDF Was Tasked with Infusing Israeli Youth with a Fighting Spirit by} Educating Them in Jewish Heritage, including the Bible

The third religion-security belief of Ben-Gurion was that Jewish tradition could serve his strategy to counter the quantitative advantage of the Arab states by cultivating the qualitative advantages of Israel's soldiers-their morale and fighting spirit. Ben-Gurion perceived that the IDF's strong fighting spirit-the reason why Israel had emerged victorious from the War for Independence-was in decline because of another Israeli strategy of contending with the Arab states' numerical advantage-bringing in masses of Jewish immigrants. "The new immigrants, who are a majority in the army and the nation, do not have the education and knowledge and understanding and enrooting and love for the Land" (Ben-Gurion 1981, p. 9). His solution was to entrust the IDF with the task of educating Israeli youth and immigrant soldiers in Zionist ideology, utilizing the Hebrew Bible to achieve this 
goal. Immigrant soldiers studied forty chapters of the Old Testament, which establish the connection between the Jews and the Land of Israel, and recount the heroic military deeds of Jewish Biblical figures (Ben-Gurion 1981, p. 10). At their induction ceremony, every recruit, immigrant or not, received a copy of the Hebrew Bible, along with a weapon (Cohen 2013, p. 114-15).

Together with the more substantial "secular" elements in his security doctrine, these three "religious" elements in Ben-Gurion's security doctrine informed Israel's security doctrine in the following decades. By the 1970s, they achieved far more than the goal Ben-Gurion had set, opening a new chapter in Israeli national security history, and in the involvement of religion in Israel's security environment, as the next section demonstrates.

\section{The Change: Israel's Security Environment Began to Religionize after 1967}

If, for young Israel, the adversary was a secular actor for whom the religious component in its resistance to Israel was secondary to the national component, the same cannot be said for Israel at the end of the 20th century. Since the late 1970s, Israel's map of threats has turned decisively religious, with the Islamic faith becoming the main motivating factor of those waging an armed struggle against Israel.

This process has been a gradual one. It began in the 1980s, when Islamic actors joined the struggle against Israel for the first time since the War of Independence. Some of these actors were newly established, like Hezbollah and the Islamic Jihad in Palestine; some were newly Islamized, like Iran. In the 1990s, these Islamic actors surpassed the secular actors in the threat they posed to Israel's security. Iran was developing weapons of mass destruction and long-range missiles with Israel's name on them and, in April 1993, the armed Islamic movements in Gaza imported the Iranian-Lebanese Shiite practice of suicide attacks to the Palestinian theater (Peri 1999, pp. 229-30; Iserovich 2005, pp. 282-89; Inbar 2008, p. 168). In the early 2000s, the religionization of the Palestine Liberation Organization (PLO) and the Palestinian political system was complete, and the Palestinian National Authority (PA) joined the Palestinian Islamic movements in cooperating with Iran, Syria and Hezbollah. Israel now saw itself contending with a security alliance which all Israel's enemies had joined and which enclosed Israel from all sides. After twenty years in which Israel had no longer feared a coordinated Arab attack on all its borders, the fear of a coordinated multifront attack returned-this time by a mostly Islamic enemy. This newly united enemy was dubbed by Israel in the early 2000s the "Radical Front", rather than the "Islamic Front", due to the inclusion in the front of Syria, Israel's only enemy that did not then, and still does not now, self-identify as Islamic.

Religion, however, does play a part in Syria's alliance with revolutionary Islamic actors in the Middle East. The religious affiliation between Shiite Iran and the Syrian Alawite (Shiite) regime which rules an otherwise predominantly Sunni population was one of the main reasons Syria formed a political alliance with Iran after the Islamic Revolution (Rabinovitch and Brun 2017, p. 25).

Israel's new fear of an Islamic coordinated attack reached a peak during 2011-2013, the first years of the Arab Spring, and has decreased somewhat since then (Magen 2015, pp. 119-20). During the Arab Spring, the Islamic encirclement of Israel was seen as almost complete, as new Islamic actors joined old ones in launching attacks from Israel's borders. New Jihadist groups joined Hezbollah on the Syrian border; in Egypt, a Muslim Brotherhood government came to power and Salafi-Jihadist groups were established in the Sinai. The IDF's 2013 assessment of how a future confrontation might begin envisioned a multifront confrontation: Islamist organizations, trying to penetrate the Golan Heights, Hezbollah firing rockets on all of Israel, jihadists in Sinai firing rockets on Eilat, and Hamas activists storming an Israeli checkpoint on the Gaza border (Freilich 2018, pp. 57, 68). In August 2013, Egypt's Muslim Brotherhood government was toppled by a military coup, and the new regime was as anxious as Israel to keep their peace agreement and eradicate the jihadists in Sinai. However, the preoccupation of Israel's security system with religion's role in shaping the environment in the Middle East remained, as is evident in the 2016 assessment of the chief of Israel's Military Intelligence Directorate, Herzi Halevi: "We are moving from a conflict of borders to a conflict of religions, especially inside Islam, between Sunna and Shia, but also between Radical Islam against Western culture" (Ofer 2016). 
At the start of the 2020s, as the Syrian regime no longer poses a military threat to Israel due to nine years of civil war, all the actors working against Israel are religious. For 21st century Israeli decisionmakers, the strategic reference point is no longer the secular Arab countries, as it was until the 1970s. It is no longer a Palestinian nationalist movement, guided by a secular ideology and having no religious goals, as it was between the 1970s and the 2000s. It is revolutionary, radical Islamic actors, most of them nonstate.

This religionization of Israel's map of threats is closely tied to the remarkable success of Ben-Gurion security doctrine-with its three "religious" key-points-in achieving its goals. Under the doctrine, Israel defeated every coordinated attack by the Arab countries and removed the historical part of Jerusalem, lslam's third most sacred place, from Muslim custodianship in the 1967 War. The 1967 loss of Arab control over the parts of Jerusalem historically important to Muslims, especially the Al-Sharif compound, was a seminal event for modern Islam and Middle Eastern politics. In Muslim discourse, it is called the "Naksa" - the "failure" or the "disaster" in Arabic (Milton-Edwards 2006, p. 78). This humiliation of the Arab-Muslim world, together with dire social and economic conditions in the Arab states, constituted a catalyst of "disenchantment" of the Arab world from the secular ideologies of Pan-Arabism and Marxism during the 1970s (Hatina 1994, p. 14; Steinberg 2002, p. 128). Mati Steinberg's description of the Islamization that followed in the Gaza Strip during the 1970s is true of the Islamization that took place in the entire Middle East: "While the generation of the 1950s found its way to nationalism after it despaired of Islam, some of the new generation of the 1970s paved a way for itself through a return to Islam, after it lost its taste for nationalism" (Steinberg 2002, p. 128).

The close connection between security events and individual religiosity was also evident on the Jewish side of the Israel-Arab conflict. The conquest, during the 1967 Six Day War, of the Old City of Jerusalem and biblical areas of Israel, including the Cave of the Patriarchs, Rachel's Tomb and Joseph's Tomb, brought about a national and religious revival for Jews in Israel and the world over (Sandler 2007, p. 354). The 1973 Yom Kippur War reinforced this religionization process. A crisis of faith in the secular ideology of socialist Zionism, which had dominated the state since its inception, was sparked by the failure of Israeli intelligence to get wind of the coming attack of the Egyptians and Syrians, the helplessness of the political and military leaderships during the first days of the war, and the high number of casualties at the end of the war. Many young Israelis began to search for meaning in alternative, spiritual ideologies, including those of Judaism and the Jewish settlement enterprise in the liberated territories, spearheaded by Israel's national-religious community (Baumgart-Ochse 2014, p. 416).

The Jewish settlement enterprise in the territories was as much a result of the Yom Kippur War as of the Six Day War. It began in 1974, when the religious-national movement sought to strengthen the weakened national morale in the aftermath of the Yom Kippur War and to prevent future withdrawals from Judea, Samaria and Gaza, like the withdrawals from parts of Sinai and the Golan Heights which Israel had agreed to under the 1973 ceasefire agreements (Peri 1999, p. 90; Baumgart-Ochse 2014, p. 416). The settlement enterprise has mostly attracted religious Jews and is guided by an ideology that is clearly religious and messianic in nature. This has provided additional vindication for the Arab world's reinterpretation of its conflict with Israel as a conflict between religions, rather than nations.

How did the religionization of the Arabs and the Jews influence the manner in which Israeli national-security policymakers related to religion? This is what the next section will explore.

\section{Religion in Israel's Security Policy Post-Religionization}

Overall, post-religionization, most of Israel's operational presumptions on religion and security remained the same after the religionization of the Middle East, with the exception of the perception that Islamism is preferable to secular Palestinian nationalism. There are more similarities than differences between the approach of modern Israel towards its new religious enemies and that of young Israel to its old enemies, the Arab countries. Most major changes in the Israeli religion-security nexus took place in the realm of what Israeli policymakers believed Israel could achieve in its religionized environment. 
4.1. Religion Is No Longer Considered a Secondary Source of the Enemy's Hostility; However, Israel's Approach to Deterring Islamic Actors Is Similar to Its Past Approach to Deterring Arab States

The most profound change in the Israeli assessment of the link between religion and national security occurred in the late 1980s, when Israel no longer viewed the growth of Islamism in the Gaza Strip as a positive development to its security. During the 1970s, Israeli authorities viewed favorably the growth of Islamism in the Palestinian street because they believed that it would block the PLO's national influences, and that focusing on religious studies would reduce participation in hostile activities against Israel (Iserovich 2005, p. 252-53). Therefore, the Military Governorate in the territories did not try to hinder the growth of new Islamic organizations and even supported the establishment of the Islamic University in Hebron-which would become one of the strongest centers in the struggle against the peace process and recognition of Israel (Zelkovitz 2012, pp. 86-87). Even when, during the 1987 Intifada, one of these new organizations, the Gazan branch of the Muslim Brotherhood, established an armed wing called Hamas to participate in anti-Israel violence, Israel deemed Hamas as preferable to the PLO. Only after Hamas published its charter in August 1988-which declared that Jihad against Israel "is the personal responsibility of every Muslim" until Israel is annihilated-did Israel cease viewing Islamism as preferable to the PLO's nationalist agenda (Iserovich 2005, p. 263-64).

Once the Islamist Palestinian organizations were "reclassified" as security threats, however, Israel's assessment of the best way to deter them was very similar to its prior assessment of how to deter the secular Arab countries. Both before and after the religionization of its enemies, Israel judged the other side as simultaneously motivated by a genuine ideological belief and rationale. During both periods, the enemies' ideology against Israel was judged as fundamental, impossible to change through diplomacy or war and, thus, spelling a long, protracted conflict-an assumption some called "the first principle of Israeli national security doctrine" (Laish 2015, p. 8). Despite its fundamental ideology, the enemy was considered rational, and influenced by a myriad of political and social factors in its deliberations as to whether to escalate the armed struggle against Israel at a given time-factors which Israel aimed to manipulate in its deterrence efforts. For example, aware of the importance for Hezbollah of retaining the support of the Shi'i population of south Lebanon, Israel attacked South Lebanon's civilian infrastructure during the Second Lebanon War, hoping it would pressure the Shi'i Lebanese to turn against Hezbollah, which would force it to stop the rocket fire on Israel (Montgomery and Pettyjohn 2010, p. 549).

Just as young Israel understood that the ideological hostility of Arab countries was informed by many nonreligious sources, post-1970s Israel understood that the religionization of its enemies was closely related to social variables such as socio-economic poverty. Indicators of the growing religionization among previously secular Palestinian organizations were interpreted as reflecting both the authentic religionization of their leadership and lip service, designed to retain the support of an Islamizing population (for example, Zelkovitz 2012, p. 82, and Halevi 2017). The likelihood of the Palestinian population joining the armed Palestinian groups in the violence against Israel at a given time was perceived as influenced by social, political and personal factors, no less than by an individual's level of religiosity (Ofer 2016; The Meir Amit Intelligence and Terrorism Information Center 2017). This includes the decisions of many Palestinians to become suicide bombers during the Second Intifada. Israel's security apparatus understood their decisions to be motivated by the combination of a religious desire to die a martyr in jihad, along with secular factors such as a wish to avenge the death of someone in the suicide terrorist's immediate circle, humiliation suffered at the hands of Israeli forces, or the loss of hope in light of the harsh economic and social situation in the PA's territories (Shay 2003, pp. 96-98). Consequently, Israel's security agencies, including the IDF, habitually recommend that the political leadership maximize the separation between Palestinian terrorism and the Palestinian population and allow the Palestinian population to carry on with a life as "regular" as possible-even during times of military clashes-in order to eliminate the social and economic reasons behind grassroots recruitment of terrorists (see, for example, Eisenkot 2018). 
As a result of the new reality of the 21st century, there has been a slight change in the traditional Israeli assessment that engaging with the religious ideology behind the enemy's hostility to Israel is futile at best and will backfire, at worst. Traditionally, Israeli diplomacy toward the Arab and Muslim world did not deal with "religious apologetics", and Israel's psychological warfare almost never referred to matters of religion (Ferber-Goldstein 2003; Schleifer 2010). In the late 2000s, two circumstances arose simultaneously and engendered change. Social media allowed Israeli diplomacy to engage directly with the Arab world without the mediation of the Arab media, which do not interview Israelis, and a regional divide of the Shi'i-Sunni camps created a receptivity in the Muslim world for Israeli utilization of Islamic ideas to delegitimize Iran and Hamas (Israel Government Press Office 2016; The Institute for National Security Studies 2019). After the Arabic-speaking spokespersons of Israel's prime minister and the IDF opened social media accounts in the early 2010s, they frequently used Islamic theology and discourse to serve Israel's strategic aims. For example, they quoted Saudi religious scholars, who banned demonstrations and sit-ins as against Islamic values, to persuade Gaza residents not to participate in the "March of Return" demonstrations that Hamas organized during 2018 on the Gaza border (Sones 2018).

Another 21st century change in the Israeli perception of which actions would bring about dividends led to the revival of young Israel's periphery doctrine. This doctrine was abandoned from the 1960s-2000s, because it did not bring many dividends (Freilich 2018, p. 275). However, when in the early 2000s, the Israeli leadership identified growing alarm in Sunni Arab countries from the growth in power and popularity of Iran and political Islam, it returned to Ben-Gurion's view that Israel could benefit from establishing security cooperation with Muslim actors who, while officially denouncing Israel, share the same existential threat. Israel's decision to establish close liaisons with the security bodies of Arab countries was not without internal opposition. Some in the Israeli security apparatus thought it was too risky to share sensitive information on the inner workings of Israeli intelligence with Israel's former enemies, with whom diplomatic relations, if they existed at all, did not go beyond a "cold peace". However, Meir Dagan, the head of Mossad at the time, saw this alliance as essential for countering the combined force of the Radical Front, and convinced the political leadership to accept his position (Bergman 2018, pp. 579-80, 607, 625). Israel's new alliances with "moderate Arab states"-a term that had not appeared in Israeli security discourse prior to this development-thoroughly transformed Israel's freedom of action in fighting the Radical Front (Voller 2015, p. 527). This became quickly evident at the onset of the 2006 Second Lebanon War, when the Arab world stood alongside Israel in blaming Hezbollah and Iran for the outbreak of the violence-an unprecedented event, and the first time in Israel's history in which it belonged to one of the regional camps (Susser 2007, p. 190).

4.2. Israel's Willingness to Give up Territories and Holy Sites to Ensure the Existence of a Jewish-Majority State Remained, but Was Delimited by the Religionization of the Jewish Population

Giving up potential control over a sacred site, as young Israel did, is different from giving up actual control over a sacred site. After Israel conquered the territories in 1967, it showed less readiness to give up the conquered sacred sites in order to secure the existence of Israel as a Jewish-majority state. This pattern conforms with the bias known in the field of psychology and behavioral economics as "the endowment effect", in which people evaluate things in their possession as more valuable than things of similar value which are not in their possession (Kahneman et al. 1991).

This willingness did not disappear altogether. Its main post-1967 expression was in Israel's decision not to exercise full sovereignty over the Temple Mount. The Levi Eshkol government annexed eastern parts of Jerusalem within less than three weeks after their conquest—which it did not do for the rest of the territories. However, despite the fact the Temple Mount is unparalleled in sacredness in the Jewish faith, Eshkol's government chose not to impose its sovereignty on the Mount in practice, and did not to grant Jews access equal to that of the Muslims; it restricted the visiting times of Jews and all non-Muslims, and even forbade them from worshipping there at all (Sandler 2018, p. 116). Israel chose to leave the administration of the compound in the hands of the Muslims, to the Waqf and 
Jordan, even though, after 1967, Jordan's sovereignty ended at the Jordan River, far from Jerusalem (Biger et al. 2009, p. 17). Behind this decision, pushed forward by the defense minister at the time, Moshe Dayan, was the long-held belief of Israel's security establishment, inherited from Ben-Gurion's era, that if an Israeli desecration-real or intentional—of the sanctity of Islam, would have tremendous power to "inflame the entire Middle East" (as usually referred to in the discourse of Israel's security circles), then an Israeli desecration of the sanctity of the Haram-al Sharif would inflame the whole world. Not only would the entire Muslim world join the protest against Israel, but the Christian world would as well, including Israel's closest ally, the US (Ramon 1997, pp. 4-8; Reiter 2016, pp. 17-18, 64, 105-6).

Ever since, all Israeli governments have exhibited the same willingness to limit Israeli control over the Temple Mount in order to prevent anti-Israel terror, especially after it became clear during the 1990s that the Israeli-Palestinian conflict had turned into a religious one, at the heart of which stood the claims of both sides to the Temple Mount/Haram al-Sharif. As a result, the Israeli governments of the 2000s imposed even greater restrictions on the Israeli presence on the Temple Mount. When the Second Intifada broke out after a visit of MP Ariel Sharon to the Temple Mount, the government of Ehud Barak, and then of Sharon himself, allowed the Waqf to close the Temple Mount to non-Muslim visitors for two years. When Sharon opened the Mount again to non-Muslims in August 2003, he placed their visits under even harsher restrictions. Visiting hours for non-Muslims were reduced to only four hours a day, and never during times of prayer in the Mount's mosques. Jews were no longer permitted to enter the mosques or visit the Mount on Sabbaths or holidays, nor to bear Jewish ritual articles during the visit. Visits to the Mount by those having a religious Jewish appearance were limited to supervised groups accompanied by Waqf guards and Israeli police (Spector Ben-Ari 2014, pp. 7-8; Reiter 2016, p. 73). Not only did no subsequent government attempt to lift Sharon's harsher, added restrictions, but in 2015, for the first time, Israel formally affirmed that its official policy was that non-Muslims, and Jews in particular, were not allowed to pray on the Temple Mount, but only to visit (Tatarsky 2015, p. 3).

While the growing religionization of the Palestinian side in the Israeli-Arab conflict has increased the motivation of the Israeli leadership to limit Israel's presence on the Temple Mount, Israel's own growing religionization has decreased the efficacy of such a measure to prevent outbreaks of terror around the Temple Mount. A three-month wave of terror attacks in 2014, and a six-month wave that followed in 2015 occurred, inter alia, because of the latest development in the conflict's religionization on the Israeli side: a change in the position of the national-religious sector regarding visits of Jews in the Temple Mount. Until the 2010s, the Israeli rabbinical establishment, both national-religious and ultra-orthodox, supported the governmental policy of restricting Jews from entering the Temple Mount on the basis of Jewish religious law. In modern times, there is uncertainty as to the location of the Holy of Holies of the Jewish Temple on the Temple Mount—an area so sacred that only the High Priest of the Temple was permitted to enter it, and then only once a year, on Yom Kippur. Because of this uncertainty, and because most Jews do not strictly observe the rules of purification required by Jewish law when visiting the Temple Mount, the religious establishment maintained a position largely prohibiting Jews from visiting there at all. This hampered criticism by the Israeli right that Israel's Temple Mount policy desecrated its sovereignty over Jerusalem and the natural right of Jews to exercise their religious beliefs (Biger et al. 2009, p. 17).

The right's ability to push against this policy was particularly limited because of the support of the national-religious party for the policy restricting Jewish visits to Temple Mount. The national-religious community and the right have been political allies since the Six Days War, when the national-religious public began voting for the right as a bloc, and the national-religious party transferred its political allegiance from leftist Labor, the traditional ruling party, to the right-wing Likud (for more on the political transformation of the national-religious community after 1967, see Elman 2008, p. 90). However, during the late 2000s, many among Israel's national-religious orthodoxy withdrew their opposition to Jews visiting the Temple Mount. This change in the position of the national-religious community is attributable partly to the rise of the Al-Aqsa narrative in the Palestinian resistance discourse and 
the Temple Mount becoming a focus of violent riots, and partly because of the years-long lobbying of "Temple movements", organizations of national-religious activists dedicated to the re-establishment of a Jewish temple in the Temple Mount (Reiter 2016, pp. 57-61). As a result, in the early 2010s, there was a marked increase in the number of national-religious Israelis visiting the Temple Mount, accompanied by a similar increase of non-religious right-wing political figures, ministers, Knesset members, who went so far as to visit even parts of the Dome of the Rock, which Temple movement activists previously refrained from approaching, because it is believed to be the location of the Holy of Holies of the Jewish Temple. In the Knesset plenum, these politicians have proposed resolutions changing the status quo of the Temple Mount to permit worship and equal access for all religions. In 2013, the Knesset's Interior Committee, headed by Likud MK Miri Regev, dealt at length with the possibility of permitting full access to the Temple Mount to Jews. All this led to great unrest in the Muslim world and to the outbreak of extreme acts of terror around the issue of the Temple Mount in 2014-2015, hampering the governments' efforts to prevent Islamic insurgency over Jerusalem (Reiter 2016, pp. 74-77).

The political pressure of the alliance between the Likud and the national-religious sector did not deter Benjamin Netanyahu's rightist government in its efforts to preserve the status quo in Jerusalem. Did it influence Israel national security policy elsewhere? It is impossible to form a coalition in Israel's multiparty political system without at least one Jewish religious party. This political reality has great influence on Israel's domestic religion policy, but less impact on its national security policy. The religious parties have prevented some withdrawals from the 1967-acquired sacred sites. The pressure of the ultra-orthodox and national-religious sectors made Rabin's leftist government insist, during the Oslo negotiations, on retaining an Israeli presence at Joseph's Tomb and Rachel's Tomb and, in 2003, made Sharon's rightist government alter the original route of the security fence to include Rachel's Tomb inside Israel (Lehrs 2012, pp. 236-37, 241). It is said that the political pressure of the religious parties and voters has contributed to Netanyahu's firm opposition to turning over any parts of Jerusalem to the Palestinians - unlike Prime Ministers Ehud Barak and Ehud Olmert, who offered concessions on Jerusalem in their negotiations with the Palestinians (Lehrs 2013, pp. 73-75; Caspit 2017, p. 113).

On the other hand, Israeli prime ministers know that the religious sector will agree to compromises on sites less important than the Temple Mount. One example is the message the Israeli Chief Rabbis conveyed to Prime Minister Barak on the eve of the 2000 Camp David Summit, when they hinted that, unlike their firm opposition to Israel conceding sovereignty over the Temple Mount, they would not oppose transferring control of Rachel's Tomb, Joseph's Tomb or even the Cave of the Patriarchs to the Palestinians, if access to Jews, worship and security at these sites were maintained (Lehrs 2012, p. 240). Another example is the fact that since Prime Minister Ehud Barak withdrew the IDF from Joseph's Tomb at the beginning of the Second Intifada, none of the religious parties have made its return a central issue in their negotiations with the ruling parties.

To conclude the discussion on the impact of "religious" political pressure on the formulation of Israeli national security policies, one should note that Israel's security policy was not delimited by Jewish Halacha (law), which prohibits giving up Israeli control over parts of Israel that were included in the ancient Kingdom of Israel. All four of the Israeli prime ministers who parted with territories acquired in the Six Day War had at least one religious party in their coalition government: Menachem Begin who conceded the Sinai in 1979, Yitzhak Rabin who conceded parts of the Gaza Strip and West Bank in the Oslo agreements, Netanyahu who conceded parts of Hebron in 1997, and Ariel Sharon who conceded all of Gaza Strip in 2005. Begin, Netanyahu and Sharon were also right-wing and, thus, relied on a large religious constituency. However, the ultra-orthodox parties have not acted politically on this theological law, as was seen in the lack of firm objection by the Shas party (the Sephardic ultra-orthodox party) in the Oslo agreement and the Hebron agreement (Elman 2008, pp. 82, 86; Sandler 2018, p. 134; Caspit 2017, p. 131). The national-religious parties, which do act politically on it, have been unable to stop prime ministers from conceding territories even while being part of their coalitions. They have, 
however, sometimes managed to convince prime ministers to reject external pressures to freeze the construction of Jewish settlements in the territories (Elman 2008, pp. 90-91; Sandler 2018, p. 137; Rynhold and Waxman 2008).

\subsection{New Dynamics of Religion-Security in Israel Post-Religionization}

The discussion so far has demonstrated the high level of continuity in the role religion played in Israeli strategy before and after the Middle East's religionization. Now it is time to explore four new dynamics of this role as a consequence of Israel's changed religio-political realities, besides those already mentioned, which developed, such as Israel's 21st century alliance with the Sunni countries that was the result of the 1979 Islamic revolution in Iran and the development of a "war of religion" between the Sunnis and the Shi'is in the 21st century.

The first new dynamic is the Evangelist revival in the US after the 1967 war, which enabled Israel to upgrade its bilateral relations with the world's greatest power into a "special relationship". It is commonly assumed that Israel had "special relations" and a strategic partnership with the US since President Truman's recognition of the new state of Israel in 1948; however, only from the administration of Lyndon Johnson did the United States and Israel begin to form a security alliance, which developed into patron-client relations in the 1970s, and assumed the form of a "special relationship" in the 1980s (Itamar Rabinovitch's preface to Johnson 2008; Freilich 2018, p. 289).

While it was the convergence of "cold" national security interests that led to the formation of the US-Israel security alliance, there were three religious elements in American political culture that elevated this security alliance to the level of a special relationship (Mead 2008). The first religious element is the major role of Hebrew history and thought in American civil religion from its outset. Many 18th century Americans supported the idea of the return of the Jews to Judea, even before there were many Jews in the United States, or even in the Land of Israel. The second element was the formation of a liberal democratic Judeo-Christian identity in the United States in the 1950s, with the growth of its highly influential middle-class Jewish population which voted for the Democrats, and which emphasized the liberal democratic character shared by Israel and the US, in contrast to the Soviet Union. The third religious element was added after the Jewish conquest of Jerusalem during the 1967 war, which the American Evangelists interpreted as a sign that the End-Time was approaching. Thereafter, the Evangelicals experienced a process of religious revivalism, which found expression in an increased political involvement in the Republican party, among other things, and created a pro-Israel key constituency in the Republican party as well. This cross-party, nearly unconditional US support for Israeli security policy, which arose in the 1980s, continues to this day. Both the Islamization of Iran and its duel hostility towards the US and Israel, and the 9.11 attacks by Al Qaeda, strengthened the American sense of a shared identity and security predicament with Israel (Cohen-Kidron 2013, p. 5).

The formation of the Israeli-American special relationship has been one of the most profound new dynamics in Israel's post-religionization era, greatly enhancing its diplomatic, military and economic resources, and Israel's freedom of action to pursue its security policies. The benefits for Israel from this special relationship went beyond the substantial security aid and diplomatic support the US has been providing Israel since the 1980s. Israel's status in the world has risen due to the power to influence US policy attributed to American Jews. This enhanced Israel's ability to influence foreign nations, including the Muslim ones with whom Israel does not have diplomatic relations, but who seek to court the US (Medem-Friedman 2018, pp. 212-14; Cohen-Kidron 2013, p. 5).

The second new dynamic in the post-religionization era was the elevation of the war on Islamic terror and extremism to the top of the West's agenda in the early 2000s. This development significantly improved the international support and cooperation Israel received for its counterterrorism policies, separate from the influence of Israel's special relationship with the US, the country leading this war on terror. Here, the fact that Palestinian terrorism in the 2000s waves the banner of a religious struggle, combined with its strong cultural animosity toward non-Muslims, played in Israel's favor. Israel felt immediately the impact of the 9/11 terror attacks, after which complaints from 
the international community against Israel's counterterrorism actions ceased in one fell swoop, and the former began to respond to Israel's requests, such as stopping the flow of Islamic charitable funds from the entire Islamic world to Islamic terror organizations (Bergman 2018, p. 514). This pattern of increased international support for Israel's counterterrorism policies has continued ever since (Esposito 2007, p. 134; Sher and Yogev 2014, pp. 189-90).

The third new dynamic was the regional rise in the number, popularity and resources of jihadist networks following the 2003 US invasion of Iraq. This development eliminated some action alternatives from Israel's pool of alternatives, such as toppling the Hamas regime in Gaza in the 2010s. Israel's security establishment assessed that such an action would be followed by what had occurred in Iraq after the fall of Saddam Hussein, and in Syria with the outbreak of the civil war-the power vacuum left by Hamas would pull in jihadist elements even more radical than Hamas, such as Al-Qaeda, ISIS and the Salafi jihadist organizations which have grown in Gaza and the Sinai Peninsula since 2006. Consequently, Prime Minister Netanyahu removed this action from Israel's pool of alternatives, despite domestic political pressure from right-wing members of his security cabinet, including the head of the religious-national party, not to do so (Rabinovitch and Brun 2017, pp. 93-94; Dekel 2014, pp. 13-14).

The fourth and final permanent new dynamic is the adoption of "religious warfare" by Israel's enemies, and especially by Palestinian terror. The appearance of Palestinian religious warfare greatly delimited Israeli military strategy in the territories, created new challenges to the work of Mossad and the Israeli Security Agency (ISA), and frequently constituted a diplomatic landmine for Israel. Israel's security system had to undergo a long process of learning how to contend with this "religious warfare". First, Israel's security agencies found it more difficult to infiltrate religion-motivated terror groups such as Hamas, Islamic Jihad, the al-Aqsa Martyrs' Brigades, Hezbollah and Iran's Revolutionary Guard (Peri 1999, p. 231; Amidror 2002, p. 126; Byman 2011, pp. 339-40; Bergman 2018, pp. 579-80). Second, when Palestinian clergy participated in the struggle against Israel, it had to be more cautious in countering them. For example, Israel postponed the targeted assassination of Sheikh Yassin, Hamas' founder and its religious leader, several times during the Second Intifada, fearing that the assassination of a religious figure would cause more Palestinians to join the uprising (Byman 2011, p. 831).

Third, when Jewish sacred sites in the 1967 territories became constant targets of Palestinian terror, larger security forces were required to guard them, especially during Jewish holy times, when the greater numbers of Jewish celebrants increased friction with the Palestinian populations in the areas (Bergman 2018, p. 523; State of Israel 2015, pp. 51-52; Lehrs 2012, p. 242). As to non-Jewish sacred sites, the abundance of churches and mosques in the territories constituted a special challenge for Israel in the Second Intifada and onward, because Palestinian terrorists frequently used them for military purposes. The terrorists knew that the IDF would not enter them, and that the entry of the ISA into mosques required the authorization of the minister of security. In most instances, this was not given, as the entry of Israeli security forces into a house of prayer-in uniform or in plainclothes-could ignite a conflagration (Peri 1999, p. 165). This strategy of the enemy dragged Israel into several international entanglements during the Second Intifada and Operation Cast Lead when, for the first time, Israel bombed mosques in the Gaza Strip from which Hamas was launching rockets into Israel. These diplomatic international entanglements pressured the Israeli government to make concessions to the Palestinians that it would not have made initially, and forced the IDF to change its military strategy in order to reduce the possibility of similar diplomatic crises (Harel and Issacharoff 2004, pp. 248-49; Shalom 2009, p. 84; State of Israel 2009, pp. 56-61, 88-89, 144-45; State of Israel 2015, p. 167).

Finally, it should be noted that there has been a decrease in the IDF's use of the Old Testament as a means of imbuing a fighting spirit, but not for religious reasons. In the years following the first two decades of Israel's existence, the majority of IDF recruits have been native-born Israelis who are emotionally connected to the State of Israel and indoctrinated from childhood with stories of IDF heroism garnered from the state's modern military history. The IDF no longer needs the world of the Bible and ancient Jewish history to cultivate Israeli soldiers' readiness to fight. 


\subsection{In Summary of Religion's Involvement in Shaping Israel's National Security Policy Post-Religionization}

When surveying religion's involvement in shaping Israel's security policy post-religionization, we find many changes, but many continuities as well. As to its operational beliefs, Israel moved from perceiving Palestinian Islamic actors as preferable to secular Palestinian actors to considering them the most dangerous group in the Palestinian camp.

At the same time, Israel's deterrence policy toward Islamic actors continues to be the overall approach of the Israeli policy towards secular actors: assuming the rationality of the other side and focusing on the manipulation of social and political elements. Israel's readiness to relinquish control over sacred sites for the sake of a more secure state also remains, and is most evident in the self-imposed restrictions on visits by Jews to the Temple Mount which Israel adopted post- 1967 . However, such exercises of caution have been gnawed away at since the rise of religionization and nationalistic tendencies in the Israeli public. The influence of internal religious groups on security policies certainly grew after 1967, but this influence shaped only the margins of the Israeli security policy, and mostly in regard to the territories' sacred sites.

The most profound changes are found in the realm of what Israel believed could be achieved in light of changing religious circumstances. On the one hand, the adoption of "religious warfare" by Israel's enemies and the regional rise of jihadism in the Middle East after the US invasion of Iraq constituted a constant limiting factor to Israel's freedom of action. It also became far more difficult to prevent violence on the Temple Mount, due to the increased volatility of the issue of Jerusalem among Palestinians and Israeli Jews alike. Consequently, Israel placed even greater emphasis on preventing religious insurgency among the Palestinians in the territories by, for instance, easing travel and trade restrictions for Palestinians living under the PA during Muslim holidays, enabling them to visit their families, go on outings and visit the Al-Aqsa mosque (Kelner et al. 2014). On the other hand, Israel enjoyed greater international cooperation due to the religious-political transformation of the American Evangelists after 1967, the 2000s global war on Islamic terror and the "war of religion" between the Shi'i and Sunni camps. Regarding the latter regional change, Israel responded by following its pre-religionization principle of cooperating with actors who may object ideologically to Israel but see a greater threat in a shared enemy, demonstrating once again the impact of habit on the formation of national security policy.

\section{What Can We Learn from the History of Religion in Israel's National-Security Making? A Model of Religion in National Security Policies}

From a review of how religion was involved in shaping Israel's security policies before and after the religionization of the state's regional and global environment, religion's effect on national-security making can be perceived as having three tiers: (1) enduring operational beliefs on the link between the state's security and religious factors; (2) religion's influence on the ever-changing conditions of choice; and (3) the utilization of religion for the realization of national-security goals.

\subsection{First Tier: Enduring Operational Beliefs}

The first tier is the operational presumptions embedded in the state's security thinking on the relations between religion and security. Which national interests are dictated by the religious identity of the state? How does religion influence the enemy's behavior? Which relations between religion and state most secure the state or the regime? The answers decisionmakers of the same country give to these questions are relatively similar over time, for two reasons. First, they are informed by the state's political ideology and religious history. Second, they are internalized by states' organs that have high organizational memories, such as the security apparatus and the diplomatic service, which recommend them to changing heads of states.

These relatively enduring operational perceptions determine how decisionmakers assess security situations which have religious characteristics, such as those involving sacred sites or actors with different religious agendas. If those situations involve an actor capable of endangering an interest 
derived from the regime's particular religious identity or jeopardizing the equilibrium between different religious groups in the state, they would be interpreted as a threat to national security. Most actors posing a "religion threat" to the security of the regime operate under an agenda of religion, as in the case of Islamist terrorism on Israel. Yet it can also come from actors with a secular ideology, who have a position on religion or from certain religious groups. For example, far-right ideologies, targeting Jews and Muslims, can cause an outbreak of inter-religious hostilities in the country. Hence the need to talk of a religion threat to national security, rather than a religious threat to national security.

\subsection{Second Tier: Conditions of Choice}

The second tier is the delimitations placed on a government's action alternatives by the opportunities and restrictions religion poses in both the state's external environment and domestic politics. Decisionmakers' freedom of choice is determined, inter alia, by the role religion plays in global politics (e.g., Israel's enhanced freedom of action after the war on Islamic terror became the main frame for talking about religion in international politics); the role religion plays in regional politics (e.g., the greater security cooperation with Arab countries after the consolidation of the Middle East into two rival camps around the Shi'i-Sunni divide), and by bilateral relations based on religious affinity and the existence of each other's religious diasporas (e.g., the special relationship between Israel and the US). Decisionmakers' options are further delimited by domestic politics pressures that include uniformity of public opinion on religious issues and lobbying by religious actors. In the Israeli case, religious lobbying was found to be influential only on the margins of policies. The same can be said in the French case, to be discussed later.

\subsection{Third Tier: Utilization}

The third tier is governmental utilization of religion to achieve national security goals. This utilization of religion for security objectives is common, multifaceted and present in the four classic instruments of national power. Israel's use of Islamic messaging to delegitimize Hamas is an example of utilization in the informational instrument. The utilization, to be discussed below, of Hamas's religious objection to the idea of a Jewish state in Palestine by Olmert is an example of religion in the diplomatic instrument. Examples of utilization of religion in the military instrument include Ben-Gurion's use of the Bible to enhance the fighting spirit of immigrants soldiers, and the IDF's tactic of deliberately launching an aerial bombing operation on the Sabbath, in order to surprise the enemy, who knows that, except for emergencies, the IDF refrains from acting on the Sabbath, a holy day for the Jewish public and orthodox Jewish soldiers (Hassner 2016, pp. 35, 173 note 8; Shelah 2015, p. 96). As for the economic instrument, Israel does not seem to utilize religion there (nor does France), but other countries do. For example, the US conditioned foreign aid or trade agreements on increasing religious freedom and, since 1984, every Republican president has withheld USAID funding from any overseas family planning organization offering or providing information about abortions, including the UN Population Fund (Lucius 2013, pp. 63-66; Rankin 2017). Along with religion's utilization in the four instruments, there is also a fifth type of utilization-the reorganization of state-religion relations for national security purposes. This utilization is absent in the Israeli case, but exists in the French case.

\subsection{The Three Tiers Are Independent from One Another}

The three tiers follow one another in the decision making sequence, from identifying a situation, assessing its implications to the national interests, evaluating action alternatives, choosing the most beneficial alternative, and executing this choice (Rosenberg 1995; Brecher et al. 1969; Redd and Mintz 2013). A decisionmaker's perceptions of the link between their state's security and religion shape how they assess the situation and its implications for the state's security. Then, religion's role in global, regional and internal politics influences how they evaluate the options open to them, and their choice of the most beneficial action. Finally, the action chosen sometimes requires decisionmakers themselves to utilize religion for its execution. When national policymakers identify 
a religion threat (the first tier), they are more sensitive to information on the religious conditions of choice in their environment (the second tier) and they utilize religion more in their attempts to counter the threat (the third tier).

Yet, each of the three tiers is independent. Religion factors can be involved in only one tier of the process and not in the others. While governmental utilization of religion is frequently shaped by the long-term perceptions of the first tier, and by the domestic and regional circumstances of the second tier, it can also be taken in a completely utilitarian manner. A case in point is Olmert's insistence that the Quartet, on the Middle East, would make Hamas' recognition of Israel as a Jewish state one of three conditions for recognition of a Hamas-led Palestinian government. Knowing that Hamas would not agree to this condition, Olmert used Hamas's ideological-religious position to deny the Hamas regime in the Strip international recognition and support (Esposito 2007, p. 134).

Lastly, there is feedback from the third tier to the first tier of the model, meaning that the actions a state takes in the sphere of religion for national security objectives have the power to reshape the state's environment so much so, that the state's policymakers must change their beliefs on the religion-security nexus (the first tier) and on what is possible for them to achieve in the new security environment (the second tier). Feedback that irrevocably changed modern politics can be observed in American national security policy. In the 1980s, during the Cold War, American national security policy led US decisionmakers to coordinate a successful campaign with Pakistan, to propel Muslims worldwide to wage jihad against the Soviet Union after its invasion of Afghanistan in 1979. This American utilization of Islam succeeded in achieving its goal; the Soviet Union withdrew from Afghanistan and then collapsed. Radicalized Islam, however, retained its expertise and prestige to threaten superpowers, and become a real security threat to the US itself, when the armed Islamic radicals of the 1990s turned on and attacked the only remaining superpower-the US. This development, which became most evident in the 9.11 attacks, required the American policymakers of the 21st century to rethink their presumptions on the link between American security on the one hand, and Islam and religious freedom on the other-the first tier (Ahmed 2012, pp. 279-89; Shaw 2011, pp. 1-3, 27-30; Bar and Minzili 2006, p. 1).

This feedback loop between national security actions that utilize religion (the third tier) and the beliefs of later decisionmakers pertaining to the relations between religion and security (the first tier) is part of a wider feedback between national security actions and the religious sphere. All national-security measures, even those that do not utilize religion, have the power to reshape the role religion plays in the target environment-which, in turn, shapes the security situation of future policymakers of the acting state. For example, the success of the mostly secular security doctrine of young Israel contributed to the religionization of the Middle East in the 1970s and 1980s, which, later on, transformed Israel's security predicament and options. Similarly, the American attempts in the 2000s to counter the new threat of Islamic terror by a military invasion of Afghanistan and Iraq, an action that did not utilize religion for its most part, enflamed an even wider wave of religious extremism in the Middle East and reshaped the regional religious politics into a battle between two rival "religious" camps-Shi'a and Sunna-which changed the security calculations of later American administrations (Bar and Minzili 2006, p. 1). Although the influence of national security policies on the religious field is not much explored in the scholarship, this influence is as present, significant and multifaceted as the influence of the religious field on national security policymaking explored in this article.

\section{Applying the Model to France}

The three-tier model is applicable to any polity, as this section will demonstrate, using the case of France's counterterrorism policies in the 21st century.

\subsection{The First Tier of Religion's Impact on France's Counterterrorism Policy}

The story of France's national security policy in the 21st century is the story of France's counter Islamic terrorism policy, as fighting Islamic radicalization has become the main preoccupation of the 
French national security establishment since the mid-1990s. What caused this change in France's security agenda is a question that can be answered by the first tier of religion's involvement in making national security policies: the beliefs embedded in the state's security thinking on the relations between religion and security caused the French authorities from the 1990s onwards to interpret a security situation involving Muslim actors as a real threat to the political ideology of the state.

When, in the mid-1990s, an Algerian group called the Armed Islamic Group (GIA) orchestrated a series of attacks in the heart of France-in retaliation for French involvement in the Algerian civil war between the secular military regime and local Islamist movements-the French authorities and public responded with unprecedented alarm. The GIA attacks were not the first attacks by an Islamic actor on French soil, preceded as they were by the 1980s attacks by Iran and Hezbollah. But unlike Iran and Hezbollah, the North African GIA recruited accomplices among France's own citizens of North African origin - and this domestic group was flagged in 1989 as endangering the political ideology of France due to its Muslim religiosity. During the 1980s, many of the second and third generations of the 1960s and 1970s North African immigration turned to Islam as an alternative source of social identity after becoming disillusioned with their chances of ever integrating into French society (Bowen 2007, p. 83; Bowen 2009, p. 442). Their demand for the right to publicly practice, celebrate and dress in accordance with their religion, which was covered by the media in what became known as the veil affair of 1989, was portrayed by the media as challenging France's political ideology, Republicanism, which places secularism (laïcité) at the heart of the public sphere as an instrument of domestic security seeking to prevent the return of the religious violence that preceded the birth of modern France in the French Revolution of 1987. Thus, Republicanism demands that any religious attachments should be removed to the private sphere, lest they risk destabilizing the homogeneous political community (Beyler 2006; Roy 2007, p. x; Maussen 2009, p. 44). With national media and discourse playing up the connections between young girls wearing headscarves in schools and the broader "Islamic threat", the idea that Muslim religiosity stood at odds with France's political ideology spread from the fringes of the political system into its center.

This securitization of Muslim religiosity as a threat to Republicanism was why, when members of this group assisted GIA in 1995, the French authorities saw France as attacked by a unified ideological threat to its identity from the religion of Islam itself, rather than from Islamic terrorism. This securitization of Islam was shaped not only by the republican narrative of "secularism as an instrument of domestic security and national cohesion", but also by another narrative inherited from France's religious history, this time from the French administration of Muslim lands of North Africa: the narrative of the religion of Islam as unified, exceptional to all other religions, and inherently belligerent and irreconcilable with the principle of secularism. As the literature noted, this perception, which guided much of France's policy towards its North African colonies, continued to influence the French political elites long after France de-colonized, leading modern French policymakers to see all North African decedents as unified in violent opposition to France's principle of secularism (Cesari 2007, p. 37; Maussen 2009, p. 253; Bowen 2010, p. 33).

France's counterterrorism policy in the three decades to come was significantly shaped by this particular understanding of the nature of the threat facing France. The construction of Islamic identity as a threat to the secularist "soul" of the republic made nation-affirming strategies an inseparable part of the French counterterrorism policies, such as banning the wearing of the Islamic veil and the burka (in 2004 and 2010, respectively), in an attempt to place the concept of laïcite in the forefront of the collective identity. France defined "radicalism" as including only "Islamic radicalism" and deemed radical even signs associated with the process of growing Islamic religiosity that are not necessarily jihadist or violent, such as "abruptly changing their eating habits", "no longer watching television or going to the movies because of images that are forbidden to them" or "changing their attire, especially women, with clothes that conceal the body" (Giambrone 2015; National Consultative Commission on Human Rights 2017, p. 8). 
Additionally, the ideological commitment of the French political elite to the assimilationist model of republicanism led them to reject potential domestic inducements for turning to terror, such as the growth of inequalities between the native French and the North African decedents, arguing instead that Islamic terrorism is a phenomenon imported from outside France, which only French criminals enlist in (Dück and Lucke 2019, pp. 22-25). As a result, French counterterrorism policy did not include efforts to improve the socio-economic circumstances leading young French of North African origin living in the suburbs to radicalize, but instead placed a heavy emphasis on military counterterrorism operations outside France's borders, from the Balkans, Afghanistan and the Indian Ocean, to the Sahel region, Iraq and Syria (Samaan and Jacobs 2018, p. 10; de Villepin 2006, p. 6). The perception of French Islamic terrorists as nothing more than criminals also caused French policymakers to reject, up until 2014, the "soft" counterradicalization measures most Western European countries adopted after the 2004 Madrid and the 2005 London attacks, such as interventions, phone hotlines, dialogues and workshops with Muslim communities, vocational training, counseling and exit programs. This rejection was also informed by the inability of the state to engage with theological matters or religious communities, both legally and psychologically, due to its entrenched policy of laïcité (Hellmuth 2015, pp. 982-87; Ragazzi 2014, pp. 5-10).

Beside "secularism as a domestic security instrument" and "Islam as unified, exceptional, belligerent", a third operational belief on religion that has been found to be influential in shaping French counterterrorism policy over the years is associated with a past strategy of regulating religion, the strategy of Gallicanism. Gallicanism dates from the establishment of the Gallican Church (1682-790), and maintains that the best way to "neutralize" the destructive force of religions is through an official state-recognition of "organized religions" (le culte), which are closely regulated and required to select a single "privileged interlocutor" from each religion to represent them vis-à-vis the state (Caeiro 2016, p. 72). As this strategy succeeded in establishing a national form of Catholicism in France in the 17-18th centuries and the incorporation of the Jews into the state in the early 19th century, French policymakers of the 21st century were united in the belief that the best way to counter the threat posed by Islam was to domesticate it along the same lines. All French governments from the 1990s to the present adopted the policy objective of creating Islam de France (French Islam), an Islam compatible with France's republican norms, values and institutions and free from external influences. To that end, they adopted several religion-domestication measures, such as encouraging the creation of a representative body for French Muslims to serve as a privileged interlocutor of Muslims vis-à-vis the state, and encouraging the opening of imam training programs in France, so that imams preaching in France would preach a civic-minded form of Islam (Laurence and Vaisse 2006, p. 157; Laurence 2012, p. 121; Çitak 2010, p. 623; Husson 2007, p. 16).

It can be seen that the operational beliefs on religion embedded in France's political and security thinking were an enduring and significant influence on French national security policy. They greatly influenced the French understanding of a security situation involving religion as a national security threat, as well as the French understanding of the best response to this newly identified "religion threat". All the patterns mentioned here transcended any political differences that existed between the French governments of the 21st century, and the organizational memory of the Ministry of Interior-the body regulating religion in France-played a special role in the continuous turn to Gallicanism as the best security solution to the French security predicament. The influence of operational beliefs on religion, however, does not cover the entire story of religion's impact on French national security making. France's counterterrorism strategy was also delimited by the role religion played in global, regional and domestic politics, but as this delimitation was more ad-hoc and on a lesser scale, it should be referred to as an independent tier.

\subsection{The Second Tier of Religion's Impact on France's Counterterrorism Policy}

Did religion's place in France's political competition delimit which policy national security decisionmakers could adopt? It did. The anti-Muslim party, the Front National (FN), began posing 
a real political challenge to the traditional governing parties after it came second in the first round of France's 2002 presidential elections, as more and more of the French public had adopted the FN's claim that Islamic identity was a direct threat to French identity. The tight inter-elite competition compelled French decisionmakers at times toward or away from certain counterterrorism policies that were more aligned with the FN's worldview, when it seemed that the public supported that worldview. For example, after President Jacques Chirac won the second round of the 2002 election, his center-right government adopted a far more negative position against signs of Islamic worship and communalism, such as headscarves, out of the fear that the FN would repeat its 2002 victories in the spring regional election of 2004 (Kuru 2009, p. 129; Bowen 2007, pp. 242-43). In another case, Interior Minister Nicolas Sarkozy moved away from his intention to modify Article 2 of the Law of 1905, to allow the state to fund mosques and other houses of worship, after almost all sectors of the French population declared their opposition, as such a modification would reduce France's Laïcité, which is the best weapon against Islamic communalism (Peter 2008, p. 101; Bowen 2007, pp. 60-61). This illustrates that, as in Israel, the pressure of unified French public opinion on religious matters was found to delimit which counterterrorism measures decisionmakers were able to adopt, although it did not seem to influence the heart of French strategy.

What of policy opportunities and constraints coming from religion's role in the international arena? In addition to worsening an already existing religion threat, the global religious phenomenon of the rise of jihadism and Islamism during the 21st century also delimited France's freedom of action in pursuing external measures against Islamic terrorism. For example, the rise to power of an Islamist government in Tunis during the Arab Spring halted security cooperation with the country for a few years, since France's secularist identity made President Francois Hollande's government reluctant to cooperate with an Islamist government-a reluctance that was not shared at the time by other European countries, such as Germany (Krüger and Ratka 2015, pp. 49-54). This illustrates the interaction between the first and the second tiers.

On the other hand, for France, as for Israel, the external religious phenomena of the global war on terrorism and the Middle Eastern "war of religion" between Shi'i Iran and Sunni Arab countries enhanced the policymakers' freedom of action, as it generated significantly greater external support for France to fight against jihadist terrorism. For example, after the launch of the global war on terrorism, France enjoyed greater security cooperation from other European countries which, before 9.11, all too often responded indifferently to its frequent requests for international cooperation in the fight against Islamic terrorism (Cettina 2003, p. 92). Additionally, the deterioration of relations between the Sunni Gulf countries and the US, due to the latter's Middle East policy that tipped the scales of power toward Iran, allowed France to fill the vacuum and to foster exceptionally close relations with the Sunni Gulf countries, which helped in the pursuit of French interests in the region, including counterterrorism interests (Barnes-Dacey 2015; Chacker 2018; Samaan 2018).

Thus, after the factors of the first tier shaped the French understanding of the nature of the threat it was dealing with and the best strategy to counter it, the factors of the second tier-religion's role in international, regional and domestic politics—delimitated France's implementation of this strategy.

\subsection{The Third Tier of Religion's Impact on France's Counterterrorism Policy}

Further to strategy implementation, the remaining part of religion's impact on French national security policy is the government's utilization of religion for the sake of counterterrorism objectives.

Like Israel, the French governments utilized religion in the diplomatic, military and informational instruments. In the military instrument, for example, the French military and police tried to recruit youths of North African origin, because familiarity with Muslim culture and the Arabic language was necessary for the success of counterterrorism missions in the 21st century (Bertossi 2014, p. 84). In the diplomatic instrument, we have President Hollande holding the first official meeting of his 2013 visit to Mali in the ancient Djingareyber mosque in Timbuktu, six days after French forces liberated the city from Al-Qaeda forces, in order to reinforce the image of France as the savior of Mali's cultural 
heritage, rather than a neo-colonizing force (Associated Press 2013). This utilization is an example of a utilitarian utilization of religion, as secularist France does not usually mix religion and state affairs. In the informational instrument, during the 2000s, French leadership propagated the message that, rather than a clash of civilizations between the West and Islam, there was a clash between states and "extremists" who "hijack Islam's humanist tradition and pervert the religion for the goals and causes that the criminals claim to be serving", in the words of the French 2006 white paper (de Villepin 2006, p. 114; Bosco 2014, pp. 42, 72-73; Fragnon 2019; Dück and Lucke 2019, pp. 15-16). These are just a few examples of France's utilization of religion in these three instruments.

In addition, France exhibited a type of utilization of religion that is missing from the Israeli case- the reorganization of religion-state relations for national security goals. For example, banning the wearing of the Islamic veil in schools and the burka anywhere in public. The reorganization of religion-state relations for national security goals is a common enough practice among countries and it is done for a variety of reasons. Saddam Hussein secularized Iraq during the Iran-Iraq War in order to win the ideological battle against newly-Islamized Iran, despite domestic pressures inside Iraq for Islamization (Baram 2011, pp. 5-7), whereas General Zia ul Haq religionized Pakistan in the early 1980s, in order to create more religious-oriented students who would join the jihad against the Soviets in Afghanistan (Ahmed 2012, p. 286). Israel, on the other hand, has not opted for this practice in its fight against Islamic terror, as one of its operational beliefs on religion is that any change in the existing religious status quo regarding Islam is bound to cause further violence against the state, thus illustrating the connection between the first and the third tiers. Another example of this connection is the fact that secularist France utilized religion less than Israel did. For example, unlike the utilization of Islamic ideas by the Israeli diplomacy apparatus in the 2010s, or the German campaign explaining to the public Islamic terms, such as jihad or Khilafa, France ruled out the use of religious ideas or themes, or engaging with the religious worldviews of jihadi terrorists, in its informational campaigns (Mielcarek 2015; Said and Fouad 2018, p. 7; Hughes 2019, pp. 61-63).

Finally, there has been feedback between France's utilization of religion (third tier) and the French understanding of the nature of the threat (first tier). The French reorganization of religion-state relations in the form of banning Islamic female wear, along with France's harsh nonreligious counterterrorism measures, fed the radicalization of the Islamic milieu in France. As more and more youths of North African origin became radicalized and joined Islamic terror groups, French policymakers had to change their long-standing objection to soft deradicalization measures as "inappropriate", when it became evident that hard deradicalization measures were insufficient to prevent radicalization.

All in all, it can be seen that religion's involvement in shaping France's national security policies can also be analyzed through the operational beliefs-conditions of choice-utilization model offered by this article. There is every reason to believe that this model fits other polities as well, but it must be empirically tested.

\section{Conclusions}

This article offered a three-tier model of the involvement of religion in national security making, based on the case of Israel before and after the religionization of its environment in the late 1970s-early 1980s. This model was found to apply to France as well, which presented a type of governmental utilization of religion for national security goals absent from the Israeli case-the reorganization of religion-state relations for national security goals. A further example, the American case, provided a utilization of religion in the economic instrument absent from both the Israeli and the French cases. The model can only grow and benefit by application to other countries, where it should reveal common governmental practices absent in the Israeli, French and US cases.

If "God is in the details", then so is religion's involvement in making national security policies. The same mechanisms of religion's influence on policy exist in all countries: the way the religious demographics of the state and its religious identity inform national interests, the presumptions of political and security decisionmakers about the link between religion and security, and religion's role in 
shaping international, regional and domestic politics. However, their expressions completely depend on the local context. Thus, religion's involvement in national security making cannot be inferred from a single case to all others, or from one "era of religion" to another. Nor can it be divined from the current state of knowledge. The existing scholarship is, as yet, unable to answer basic questions such as: What circumstances lead states to utilize religion for security objectives? In which states do internal religious politics have a greater influence on shaping security policy? What kinds of states make the broadest use of religion to achieve security goals? Are there geographic differences in the involvement of religion in determining security policy? These topical questions can only be answered by systematic compilation and comparison of in-depth analyses of multiple case-studies along the various religious factors identified in this article.

Funding: This research received no external funding.

Conflicts of Interest: The author declares no conflict of interest.

\section{References}

Ahmed, Zahid Shahab. 2012. Political Islam, Jamaat-e-Islami, and Pakistan's role in the Afghan-Soviet War, 1979-1988. In Religion and the Cold War: A global Perspective. Edited by Philip E. Muehlenbeck. Nashville: Vanderbilt University Press, pp. 275-96.

Allon, Yigal. 1990. Tricks of War: Issues of Security Matters. Tel Aviv: Hakibbutz Hameuchad, Sifriat Poalim Publishing. (In Hebrew)

Amidror, Yaacov. 2002. Intelligence and National Security, and the Special Case of Counter Terrorism Intelligence. In Introduction to National Security; Tel Aviv: Ministry of Defense Publishing, pp. 117-28. (In Hebrew)

Associated Press. 2013. Hollande visits troops in Mali. The Irish Times. February 2. Available online: https://www.irishtimes.com/news/hollande-visits-troops-in-mali-1.1254668 (accessed on 19 February 2020).

Bar, Shmuel, and Yair Minzili. 2006. The Zawahiri Letter and the Strategy of Al-Qaeda. Current Trends in Islamist Ideology 3: 38-51.

Baram, Amatzia. 2011. From Militant Secularism to Islamism: The Iraqi Ba'th Regime 1968-2003. History and Public Policy Program Occassional Paper. Washington: Woodrow Wilson International Center for Scholars.

Bar-Maoz, Moria. 2018. On Religion and the Politics of Security: How Religion's Involvement in Domestic Politics Affects National Securitymaking. The Review of Faith \& International Affairs 16: 36-49.

Barnes-Dacey, Julien. 2015. France's deepening relations with the gulf. The European Council on Foreign Relations Website. Available online: https://www.ecfr.eu/article/commentary_frances_deepening_relations_with_the_ gulf (accessed on 18 February 2020).

Bar-On, Mordechai. 2018. Six Days-A Watershed? Cleavages in the Way Israelis View Their History. Israel Studies 23: 11-17. [CrossRef]

Baumgart-Ochse, Claudia. 2014. Opposed or Intertwined? Religious and Secular Conceptions of National Identity in Israel and the Israeli-Palestinian Conflict. Politics, Religion \& Ideology 15: 401-20.

Ben-Gurion, David. 1981. The Military and the State. Maarchot 279-280: 2-11. (In Hebrew).

Bergman, Ronen. 2018. Rise and Kill First: The Secret History of Israel's Targeted Assassinations. New York: Random House.

Bertossi, Christophe. 2014. French 'Muslim' Soldiers? Social Change and Pragmatism in a Military Institution. In European States and their Muslim Citizens: The Impact of Institutions on Perceptions and Boundaries. Edited by John R. Bowen, Christophe Bertossi, Jan Willem Duyvendak and Mona Lena Krook. Cambridge: Cambridge University Press, pp. 73-103.

Beyler, Clara. 2006. The Jihadist Threat in France. Current Trends in Islamist Ideology 3: 89-113.

Bialer, Uri. 1987. Ben-Gurion and the Question of the International Orientation of Israel 1948-1956. Cathedra: For the History of Eretz Israel and Its Yishuv 43: 145-72. (In Hebrew).

Bialer, Uri. 2006. Cross on the Star of David: The Christian World in Israel's Foreign Policy, 1948-1967. Jerusalem: Yad Ben-Zvi Press, Negev: Ben-Gurion Institute for the Study of Israel and Zionism at Ben-Gurion University of the Negev. (In Hebrew) 
Biger, Gideon, Yosseph Shilhav, Amiram Gonen, Rachel Machtiger, and Daniel Reisner. 2009. Sovereignty in Jerusalem-Theory and Practice. Available online: https://www.idc.ac.il/he/research/ips/documents/ publication/1/3017ribonut2009.pdf (accessed on 28 December 2018). (In Hebrew).

Bosco, Robert. 2014. Securing the Sacred: Religion, National Security, and the Western State. Detroit: University of Michigan Press.

Bowen, John R. 2007. Why the French Don't Like Headscarves: Islam, the State, and Public Space. Princeton: Princeton University Press.

Bowen, John R. 2009. Recognising Islam in France after 9/11. Journal of Ethnic and Migration Studies 35: 439-52. [CrossRef]

Bowen, John R. 2010. Can Islam Be French? Pluralism and Pragmatism in a Secular State. Princeton: Princeton University Press.

Brecher, Michael, Blema Steinberg, and Janice Stein. 1969. A Framework for Research on Foreign Policy Behavior. The Journal of Conflict Resolution 13: 75-101. [CrossRef]

Byman, Daniel. 2011. A High Price: The Triumphs and Failures of Israeli Counterterrorism. Oxford: Oxford University Press.

Caeiro, Alexandre. 2016. Religious Authorities or Political Actors? The Muslim Leaders of the French Representative Body of Islam. In European Muslims and the Secular State. Edited by Jocelyne Cesari and Sean McLoughlin. Abingdon-on-Thames: Routledge, pp. 71-84.

Caspit, Ben. 2017. The Netanyahu Years. Rishon Letsion: Yediot Achronot, Hemed Books. (In Hebrew)

Cesari, Jocelyne. 2007. The Muslim Presence in France and the United States: Its Consequences for Secularism. French Politics, Culture \& Society 25: 34-45.

Cettina, Nathalie. 2003. The French Approach: Vigour and Vigilance. In Confronting Terrorism: European Experiences, Threat Perceptions and Policies. Edited by Marianne Van Leeuwen. The Hague: Brill, pp. 71-94.

Chacker, Rachid. 2018. The Perception of the Gulf States in France. In The Arab Gulf States and the West: Perceptions and Realities_-Opportunities and Perils. Edited by Dania Koleilat Khatib and Marwa Maziad. Abingdon-on-Thames: Routledge, pp. 65-81.

Çitak, Zana. 2010. Between 'Turkish Islam' and 'French Islam': The Role of the Diyanet in the Conseil Français Du Culte Musulman. Journal of Ethnic and Migration Studies 36: 619-34. [CrossRef]

Cohen, Hillel. 2003. Book Review: The Fatah Movement: Islam, Nationalism and Armed Struggle Politics. The New East: Journal of the Middle East and Islamic Studies 52: 348-52. (In Hebrew).

Cohen, Stuart A. 2013. Israel. In Religion in the Military Worldwide. Edited by Ron E. Hassner. Abingdon-on-Thames: Routledge, pp. 114-42.

Cohen-Kidron, Ram. 2013. Updating Israel's Security Strategy in an Era of Uncertainty. Strategy Research Project. Washington: Army War College Publications, Available online: http://www.dtic.mil/dtic/tr/fulltext/u2/ a589121.pdf (accessed on 15 August 2018).

de Villepin, Dominique. 2006. Prevailing Against Terrorism: White Paper on Domestic Security against Terrorism. Paris: La Documentation Française.

Dekel, Udi. 2014. Operation Protective Edge: Strategic and Tactical Asymmetry. In The Lessons of Operation Protective Edge. Edited by Anat Kurz and Shlomo Brom. Tel Aviv: Institute for National Security Studies, pp. 13-20.

Drew, Dennis M., and Donald M. Snow. 2006. Making Twenty-First-Century Strategy. An Introduction to Modern National Security Processes and Problems. Maxwell: Air University Press.

Dück, Elena, and Robin Lucke. 2019. Same Old (Macro-) Securitization? A Comparison of Political Reactions to Major Terrorist Attacks in the United States and France. Croatian International Relations Review 25: 6-35. [CrossRef]

Eisenkot, Gadi. 2018. An Address by IDF Chief of Staff. In Proceedings of the Annual Conference on the IDF and Israeli Society in Honor of the Late Lt. Gen. Amnon Lipkin-Shahak, Herzliya, Israel, December 28; Available online: www.youtube.com/watch?v=Rud4swivXKo (accessed on 18 February 2020). (In Hebrew).

Elman, Miriam. 2008. Does Democracy Tame the Radicals? Lessons from Israel's Jewish Religious Political Parties. Asian Security 4: 79-99. [CrossRef]

Esposito, Michele K. 2007. Quarterly Update on Conflict and Diplomacy: 16 November 2006-15 February 2007. Journal of Palestine Studies 36: 132-60. [CrossRef] 
Farr, Thomas F. 2008. Diplomacy in an Age of Faith: Religious Freedom and National Security. Foreign Affairs 87: 110-24.

Ferber-Goldstein, Sari. 2003. Psychological Warfare in the Territories and the Mental Profile of the Suicide Bomber. Maarchot 389: 16-29. (In Hebrew).

Fischer, Yochi. 2015. An Introduction: Secularization and Secularism-A Theoretical and Methodological Platform. In Secularization and Secularism: Interdisciplinary Perspectives. Edited by Yochi Fischer. Jerusalem: Van Leer Institute Press, Tel Aviv: Hakibbutz Hameuchad, pp. 11-43. (In Hebrew)

Fragnon, Julien. 2019. 'We Are at War': Continuity and Rupture in French Anti-Terrorist Discourse. Media, War and Conflict 12: 131-52. [CrossRef]

Freilich, Charles D. 2018. Israeli National Security: A New Strategy for an Era of Change. Oxford: Oxford University Press.

Giambrone, Andrew. 2015. How to Spot a Jihadist France Transitions from \#JeSuisCharlie to \#StopDjihadisme. The Atlantic. Available online: https:/www.theatlantic.com/international/archive/2015/01/how-to-spot-ajihadist-france/385010/ (accessed on 1 April 2020).

Gray, Colin S. 1982. Strategic Studies and Public Policy: The American Experience. Lexington: The University Press of Kentucky.

Gray, Colin S. 2016. Strategy and Politics. Abingdon-on-Thames: Routledge.

Halevi, Herzi. 2017. A Review by the Chief of the Israeli Military Intelligence Directorate. In Proceedings of the Annual Herzliya Conference, Herzliya, Israel, June 22; Available online: https://www.youtube.com/watch? $\mathrm{v}=\mathrm{Wl} 2 \mathrm{O} 8 \mathrm{gxz}$ lJE (accessed on 18 February 2020).

Harel, Amos, and Avi Issacharoff. 2004. The Seventh War: How We Won and Why We Lost the War with the Palestinians. Tel Aviv: Miskal. (In Hebrew)

Hassner, Ron E. 2009. War on Sacred Grounds. Ithaca: Cornell University Press.

Hassner, Ron E., ed. 2013. Religion in the Military Worldwide. Cambridge: Cambridge University Press.

Hassner, Ron E. 2016. Religion on the Battlefield. Ithaca: Cornell University Press.

Hatina, Meir. 1994. Palestinian Radicalism: The Islamic Jihad Movement. Tel Aviv: The Moshe Dayan Center of Tel Aviv University. (In Hebrew)

Hellmuth, Dorle. 2015. Countering Jihadi Terrorists and Radicals the French Way. Studies in Conflict and Terrorism 38: 979-97. [CrossRef]

Hughes, Simeon Michel. 2019. Governmentality in Counter-Terrorism: The French Response to Returning Foreign Terrorist Fighters. Master's Thesis, University of Amsterdam, Graduate School of Social Sciences, Amsterdam, The Netherlands, June 21.

Husson, Jean François. 2007. Training Imams in Europe: The Current Status. Brussels: King Baudouin Foundation.

Inbar, Efraim. 2008. Israel's National Security: Issues and Challenges since the Yom Kippur War.. Abingdon-on-Thames: Routledge.

Iserovich, Hayim. 2005. The Development of Counterterrorism Doctrine in Britain and Israel in the Years 1968-2005. Ph.D. Dissertation, Bar-Ilan University, Ramat Gan, Israel. (In Hebrew).

Israel Government Press Office. 2016. Meet the spokesperson: Ofir Gendelman, the Prime Minister's Spokesperson for the Arab Media. Available online: https://www.youtube.com/watch?v=BAXhYzgABkc (accessed on 18 March 2019).

Johnson, Robert David. 2008. Lyndon Johnson and Israel: The Secret Presidential Recordings. Tel Aviv: The S. Daniel Abraham Center for International and Regional Studies, Tel Aviv University.

Kahneman, Daniel, Jack L. Knetsch, and Richard H. Thaler. 1991. Anomalies: The Endowment Effect, Loss Aversion, and Status Quo Bias. The Journal of Economic Perspectives 5: 193-206. [CrossRef]

Kelner, Yaron, Noam Dabul Dvir, Omri Efraiim, Yoav Zaytun, Ilana Koriel, and Achiya Ra'abad. 2014. Yom Kippur: Curfew in Judea and Samaria, increased deployment in mixed cities due to Eid Al-Adha holiday. Ynet. October 3. Available online: https://www.ynet.co.il/articles/0,7340,L-4577137,00.html (accessed on 31 December 2019). (In Hebrew). 
Krüger, Laura-Theresa, and Edmund Ratka. 2015. Adapting Foreign Policy to a Country in Transition: France, Germany and the New Tunisia. In The Tunisian Constitutional Process: Main Actors and Key Issues. Edited by Mathieu Rousselin and Christopher Smith. Duisburg: Käte Hamburger Kolleg/Centre for Global Cooperation Research, pp. 46-56.

Kuru, Ahmet T. 2009. Secularism and State Policies toward Religion: The United States, France, and Turkey. Cambridge: Cambridge University Press.

Laish, Gur. 2015. The Principles of the Security Doctrine of Israel National Security Council—For Routine and Emergency. Available online: http://maarachot.idf.il/PDF/FILES/9/113729.pdf (accessed on 5 September 2018). (In Hebrew).

Laurence, Jonathan. 2012. The Emancipation of Europe's Muslims: The State's Role in Minority Integration. Princeton: Princeton University Press.

Laurence, Jonathan, and Justin Vaisse. 2006. Integrating Islam: Political and Religious Challenges in Contemporary France. Washington: Brookings Institution Press.

Lehrs, Lior. 2012. Political Holiness: Negotiating Holy Places in Eretz Israel/Palestine, 1937-2003. In Sacred Space in Israel and Palestine: Religion and Politics. Edited by Marshall J. Breger, Yitzhak Reiter and Leonard Hammer. Abingdon-on-Thames: Routledge, pp. 228-50.

Lehrs, Lior. 2013. Peace Talks on Jerusalem: A Review of the Israeli-Palestinian Negotiations Concerning Jerusalem 1993-2013. Jerusalem: The Jerusalem Institute for Israel Studies.

Litvak, Meir. 1998. The Islamization of the Palestinian-Israeli Conflict: The Case of Hamas. Middle Eastern Studies 34: 148-63. [CrossRef]

Lucius, Casey. 2013. Religion and the National Security Strategy. Journal of Church \& State 55: 50-70.

Luttwak, Edward N. 1976. Strategic Power: Military Capabilities and Political Utility. Beverly Hills: Sage Publications.

Magen, Amichai. 2015. Comparative Assessment of Israel's Foreign Policy Response to the 'Arab Spring'. Journal of European Integration 37: 113-33. [CrossRef]

Mandaville, Peter, and Shadi Hamid. 2018. Islam as Statecraft: How Governments Use Religion in Foreign Policy. Washington: The Brookings Institution.

Maniv, Omri, and Yuval Benziman. 2020. National-Religionization (and Not Religious-Religionization) in Policies of Israel's Ministry of Education. Israel Studies 25: 115-37. [CrossRef]

Maussen, Marcel Johannes Marie. 2009. Constructing Mosques: The Governance of Islam in France and the Netherlands. Ph.D. Dissertation, Institute Amsterdam Institute for Social Science Research, Faculty of Social and Behavioural Sciences, Amsterdam, The Netherlands, February 12.

McGowan, Patrick J., and Howard B. Shapiro. 1973. The Comparative Study of Foreign Policy: A Survey of Scientific Findings. Beverly Hills: Sage Publications.

Mead, Walter Russell. 2008. The New Israel and the Old: Why Gentile Americans Back the Jewish State. Foreign Affairs 87: 28-46.

Medem-Friedman, Ofer. 2018. The Contribution of American Jews to Israel's National Security. In American Jews and Israel's National Security. Edited by Asaf Orayon and Shachar Eilam. Boston: The Ruderman Family Fund, Tel Aviv: Institute for National Security Studies, pp. 191-296. (In Hebrew)

Mielcarek, Romain. 2015. Stop Jihadism, Counter-Propaganda Effort Made in France. Available online: http://www.guerres-influences.com/stop-jihadisme-essai-de-contre-propagande-made-in-france/ (accessed on 1 April 2020). (In French).

Milton-Edwards, Beverly. 2006. Political Islam and the Palestinian-Israeli Conflict. Israel Affairs 12: 65-85. [CrossRef]

Montgomery, Evan Braden, and Stacie L. Pettyjohn. 2010. Democratization, Instability, and War: Israel's 2006 Conflicts with Hamas and Hezbollah. Security Studies 19: 521-54. [CrossRef]

National Consultative Commission on Human Rights. 2017. Statement of Opinion on the Prevention of Radicalisation. Available online: https://www.cncdh.fr/sites/default/files/170518_opinion_on_the_ prevention_of_radicalisation.pdf (accessed on 31 March 2020).

Ofer, Yohai. 2016. Head of Aman: Warning the enemy when it is inconvenient to hurt it. NRG. June 15. Available online: https://www.makorrishon.co.il/nrg/online/1/ART2/788/120.html (accessed on 28 January 2020). (In Hebrew).

Peri, Ya'akov. 1999. Strike First. Tel Aviv: Keshet. (In Hebrew) 
Peter, Frank. 2008. Political Rationalities, Counter-Terrorism and Policies on Islam in the United Kingdom and France. In The Social Life of Anti-Terrorism Laws. The War on Terror and the Classifications of the "Dangerous Other". Edited by Julia M. Eckert. Bielefeld: Transcript, pp. 79-108.

Rabinovitch, Itamar, and Itai Brun. 2017. Israel Facing a New Middle East: In Search of a National Security Strategy. Stanford: Hoover Press.

Ragazzi, Francesco. 2014. Towards 'policed multiculturalism'? Counter-radicalization in France, The Netherlands and the United Kingdom. Les Etudes du CERI 206: 1-37.

Ramon, Amnon. 1997. The Attitude of the State of Israel and the Jewish Public to the Temple Mount (1967-1996). Jerusalem: Jerusalem Institute of Israel Studies. (In Hebrew)

Rankin, Jennifer. 2017. Countries pledge millions to plug hole left by US 'global gag rule'. The Guardian. March 2. Available online: https:/www.theguardian.com/global-development/2017/mar/02/countries-to-join-forcesto-raise-funds--safe-abortions-trump-order-conference-global-gag-rule (accessed on 18 February 2020).

Redd, Steven B., and Alex Mintz. 2013. Policy Perspectives on National Security and Foreign Policy Decision Making. The Policy Studies Journal 41: 11-38. [CrossRef]

Reiter, Yitzhak. 2016. Status Quo in Change: The Struggles for Control on the Mount Temple. Jerusalem: The Jerusalem Institute for Israel Studies Status. (In Hebrew)

Rosenberg, Shawn W. 1995. Against Neoclassical Political Economy: A Political Psychological Critique. Political Psychology 16: 99-136. [CrossRef]

Roy, Olivier. 2007. Secularism Confronts Islam. New York: Columbia University Press.

Rubin, Lawrence. 2014. Islam in the Balance: Ideational Threats in Arab Politics. Stanford: Stanford University Press.

Rynhold, Jonathan, and Dov Waxman. 2008. Ideological Change and Israel's Disengagement from Gaza. Political Science Quarterly 123: 11-37. [CrossRef]

Said, Behnam, and Hazim Fouad. 2018. Countering Islamist Radicalisation in Germany—A Guide to Germany's Growing Prevention Infrastructure. The Hague: International Centre for Counter-Terrorism Policy Brief, Available online: https://icct.nl/wp-content/uploads/2018/09/ICCT-Said-Fouad-Countering-Islamist-Radicalizationin-Germany-Sept2018.pdf (accessed on 25 February 2020).

Samaan, Jean-Loup. 2018. French Policy in the Gulf: The Other Western Ally. In External Powers and the Gulf Monarchies. Edited by Jonathan Fulton and Li-Chen Sim. Abingdon-on-Thames: Routledge, pp. 86-101.

Samaan, Jean Loup, and Andreas Jacobs. 2018. Countering Jihadist Terrorism: A Comparative Analysis of French and German Experiences. Terrorism and Political Violence 32: 1-15. [CrossRef]

Sandler, Shmuel. 2007. Toward a Theory of World Jewish Politics and Jewish Foreign Policy. Hebraic Political Studies 2: 326-60.

Sandler, Shmuel. 2018. The Jewish Origins of Israeli Foreign Policy. Abingdon-on-Thames: Routledge.

Schleifer, Ron. 2010. The Psychological Warfare in Operation Cast Lead. Maarchot 432: 18-23. (In Hebrew).

Seiple, Robert A., and Dennis R. Hoover, eds. 2004. Religion and Security: The New Nexus in International. Lanham: Rowman \& Littlefield.

Shalom, Zaki. 2009. Decision against a Terrorist Organization: Operation Cast Lead-A Case Study. Strategic Assessment 11: 83-86.

Shaw, Jonathan E. 2011. The Role of Religion in National Security Policy since September 11, 2001. Carlisle: Carlisle Papers, Strategic Studies Institute, U.S. Army War College.

Shay, Shaul. 2003. The Shahids: Islam and Suicide Attacks. Herzliya: The Interdisciplinary Center Press.

Shelah, Ofer. 2015. Dare to Win: A Security Policy for Israel. Tel Aviv: Yediot Achronot, Hemed Books. (In Hebrew)

Sher, Gilead, and Einav Yogev. 2014. A New Opportunity to Confront the Delegitimization of Israel. In The Lessons of Operation Protective Edge. Edited by Anat Kurz and Shlomo Brom. Tel Aviv: Institute for National Security Studies, pp. 189-95.

Sieple, Chris, Dennis R. Hoover, and Pauletta Otis, eds. 2013. The Routledge Handbook of Religion and Security. Abingdon: Routledge.

Snow, Donald M. 2011. National Security for a New Era, 4th ed. Boston: Longman.

Sones, Mordechai. 2018. What Arabs think about IDF spokesman in Arabic. Arutz Seva News Website. April 8. Available online: http://www.israelnationalnews.com/News/News.aspx/244102 (accessed on 6 December 2019). 
Spector Ben-Ari, Shiri. 2014. Jewish Visit to the Temple Mount. A Report to the Interior Affairs Committee of the Knesset. Available online: https://fs.knesset.gov.il/globaldocs/MMM/00ec6d8d-f1f7-e411-80c8-00155d01107c/ 2_00ec6d8d-f1f7-e411-80c8-00155d01107c_11_6656.pdf (accessed on 25 December 2018). (In Hebrew)

State of Israel. 2009. The Operation in Gaza, 27 December 2008-18 January 2009: Factual and Legal Aspects. Available online: http://www.mfa.gov.il/MFA_Graphics/MFAGallery/Documents/GazaOperationwLinks.pdf (accessed on 6 December 2018).

State of Israel. 2015. The 2014 Gaza conflict (7 July-26 August 2014): Factual and Legal Aspects. Available online: https://mfa.gov.il/ProtectiveEdge/Documents/2014GazaConflictFullReport.pdf (accessed on 9 January 2019).

Steinberg, Mati. 2002. Religion and nationalism in the ideology of Hamas. In Religion and Nationalism in Israel and the Middle East. Edited by Neri Horowitz. Tel Aviv: Am Oved, pp. 126-75. (In Hebrew)

Susser, Asher. 2007. The regional setting: Statehood vs anarchy. In The Second Lebanon War: Strategic Perspectives. Edited by Shlomo Brom and Meir Elran. Tel Aviv: Institute for National Security Studies, pp. 175-86.

Tatarsky, Aviv. 2015. Collective Restrictions on the Entry of Muslim Worshippers to the Temple Mount/Haram Al-Sharif: A Violation of the Spirit of the Status quo and a Key Factor in the Outbreak of Violence in Jerusalem. Ir Amim Website. Available online: http://www.ir-amim.org.il/sites/default/files/ AViolationoftheSpritoftheStatusQuo_0.pdf (accessed on 22 February 2019).

The Institute for National Security Studies. 2019. Conversation between Mr Noam Manella and IDF Spokesperson Brig Gen Ronen Manelis. In Proceedings of the Annual International Conference of the Institute for National Security Studies at Tel Aviv University, Tel Aviv, Israel, January 28-29; Available online: http: //www.inss.org.il/conversation-mr-noam-manella-idf-spokesperson-brig-gen-ronen-manelis/ (accessed on 19 February 2020).

The Meir Amit Intelligence and Terrorism Information Center. 2017. Popular Terrorism: The Current Situation. Available online: https://www.terrorism-info.org.il/en/popular-terrorism-current-situation/ (accessed on 5 February 2019).

Thomas, Scott M. 2010. Religions and global security. Le religioni nelle relazioni internazionali, 4-21. Available online: http://www.ispionline.it/it/documents/QRI/QRI12.pdf (accessed on 19 February 2020).

Voller, Yaniv. 2015. From periphery to the moderates: Israeli identity and foreign policy in the Middle East. Political Science Quarterly 130: 505-35. [CrossRef]

Zelkovitz, Ido. 2012. The Fatah Movement: Islam, Nationalism and Armed Struggle Politics. Tel Aviv: Resling. (In Hebrew)

(C) 2020 by the author. Licensee MDPI, Basel, Switzerland. This article is an open access article distributed under the terms and conditions of the Creative Commons Attribution (CC BY) license (http://creativecommons.org/licenses/by/4.0/). 


\title{
Article \\ 'Moderate Islam' Made in the United Arab Emirates: Public Diplomacy and the Politics of Containment
}

\author{
Panos Kourgiotis \\ Department of Balkan, Slavic and Oriental Studies, University of Macedonia, GR-546 36 Thessaloniki, Greece; \\ pkourgiotis@gmail.com
}

Received: 2 December 2019; Accepted: 10 January 2020; Published: 13 January 2020

\begin{abstract}
This essay addresses the ideological utilization of religion in the international relations of the United Arab Emirates during the Arab Spring and beyond. By referring to the theoretical framework of public diplomacy and analyzing UAE regional and domestic attitudes, this essay intends to examine the politics of 'moderate Islam' in line with: (a) the monarchy's nation building visions for the 21st century; (b) its national rebranding strategies; (c) its geopolitical empowerment in the Gulf and the Middle East. Throughout our analysis, it is argued that even though 'moderate Islam' has been devised for creating 'soft power', it serves 'sharp power' as well. As will become obvious, this has been mainly the case as far as the containment of Political Islam is concerned.
\end{abstract}

Keywords: United Arab Emirates; Islam; public diplomacy; Gulf; Arab Spring; interfaith dialogue

\section{Introduction}

In the aftermath of the Arab Spring, certain countries in the region tried to manage the course of events in their bid to become regional superpowers. This has been especially true for the Gulf Cooperation Council (GCC) members, like Qatar or the United Arab Emirates, which is the country under question in this study (Young 2013).

Since their foundation in 1971, the Emirates have been a typical 'rentier state' (Issawi [1982] 2006, pp. 198-202; Noreng 2004, pp. 9-38) that uses its enormous resources as a means to legitimize the power sharing of several confederated dynasties; the most important among them being al-Nahyan and al-Maktoum dynasty, who govern Abu Dhabi and Dubai and hold the posts of presidency and premiership respectively (Foley 2002, pp. 38-40). The UAE were ranked, as of 2017, the 13th richest nation globally, holding the seventh and the sixth largest oil and natural gas reserves in the world (CIA The World Factbook 2017). Steps have been taken, though, to diversify the oil- and gas-dependent economy (Eno et al. 2016, pp. 102-4).

Regarding the monarchy's foreign relations, the excessive accumulation of wealth was manifested in active donor diplomacy. Billions of dollars have been paid so far in disbursements mainly to Africa, Afghanistan, the Arab countries and, to a lesser extent, the Americas, Europe and Oceania (Organization for Economic Co-Operation and Development 1971-2018). It is worth mentioning that for the years 2013-2014, the monarchy was the world's biggest donor of foreign aid, allocating 1.26 percent of its gross national income to official developmental aid (Embassy of the United Arab Emirates 2019a).

Nevertheless, donations are not the sole factor in shaping Emirati regional policies. In recent years, the country asserted a more aggressive, 'hard power' diplomacy that culminated in military interventions in a number of fronts, such as Bahrain, Syria, Libya and Yemen; still, regional hegemony cannot be sustained without the credibility of 'soft power' (Nye 2005). Until 2013, divergent priorities and security concerns over the political future of the Arab countries under transition, i.e., the role of the decades-old Islamist movements (Stein and Volpi 2015, pp. 286-88; Schwedler 2013, pp. 14-15), were crystallized into the emergence of two rival camps: the Saudi-Emirati axis and that of Qatar, 
Turkey and the transnational Muslim Brotherhood (Bianco and Stansfield 2018, pp. 625-27). In this regard, post-Mohammad Morsi Egypt received 52 percent of the Emirates' total foreign aid budget for 2014 (MEE and Agencies 2015), against the backdrop of Abu Dhabi's public diplomacy initiatives, such as the so-called 'moderate Islam' campaign (Cafiero 2019).

Therefore, this essay intends to examine the utilization of Islam in the midst of Emirati regional adventurism and generous aid policies towards countries facing the threat of Political Islam or recovering from it. The study aims to show that promoting 'moderate Islam' far exceeds the scope of cultural/religious diplomacy; it is rather a by-product, of this small power's geopolitical transformation into an international actor that aspires to lead the Arab world (Carvalho-Pinto 2014, pp. 238-41). Setting money and coercive policies aside, the ultimate goal of this strategy is to create 'soft power', yet without sacrificing 'sharp power' tactics that stem from the fear of the Muslim Brotherhood.

As suggested, Abu Dhabi's campaign has three audiences; firstly, at a global level, by improving the image of Islam through public diplomacy, the country's rulers actually attempt to optimize their own image vis-à-vis several Western nations, notably amid their war in Yemen (2015-2019) (Al-Azami 2018). Secondly, at a regional level, the UAE fervently seek to discredit the Islamists, by accusing them of distorting 'true Islam'. Thirdly, domestically, the monarchy increases its immunity against demands for political reform.

\section{Discussion}

\subsection{Contextualizing 'Moderate Islam'}

The UAE post-Arab Spring policies may seem contradictory. On the one hand, regional interference triggered civil wars and humanitarian crises; the list is quite impressive: crushing Bahraini protesters, supporting the military putsch against the first democratically elected President of Egypt, bombarding Yemen together with the Saudis and imposing an aerial and naval blockade that resulted in the spread of famine and cholera, encouraging the secession of Aden in the country's south and, last but not least, militarily backing General Haftar against the UN-recognized government of Tripoli in Libya (Holmes 2014; Nour 2018; Ramani 2019; Abdulrahim 2019). With a similar attitude, Abu Dhabi introduced compulsory military service for 12 months in 2014 that was extended to 16 months in 2018 (El Yaakoubi 2018).

On the other hand, the government announced the creation of four new ministries-Tolerance, Happiness, Youth and Future-reflecting the country's 'success story' in spite of the upheavals surrounding it. In this framework, Dubai's ruler, Mohamed bin Rashid al-Maktoum, addressed the region and the world:

The changes reflect what we have learned from events in our region over the past five years. In particular, we have learned that failure to respond effectively to the aspirations of young people, who represent more than half of the population in Arab countries, is like swimming against the tide ( ... ) We do not forget that the genesis of the tension in our region, the events dubbed the "Arab Spring," was squarely rooted in the lack of opportunities for young people to achieve their dreams and ambitions ( ... ) We have also learned from hundreds of thousands of dead and millions of refugees in our region that sectarian, ideological, cultural and religious bigotry only fuel the fires of rage. We cannot and will not allow this in our country ( ... When the Arab world was tolerant and accepting of others, it led the world: From Baghdad to Damascus to Andalusia and farther afield, we provided beacons of science, knowledge, and civilization, because humane values were the basis of our relationships with all civilizations, cultures, and religions. Even when our ancestors left Andalusia, people of other faiths went with them. (UAE The Cabinet n.d.a)

Donor diplomacy followed suit: 
The UAE aid has only humanitarian objectives. It is neither governed by politics nor is limited by geography, race, colour or religion of the beneficiary. This is a practical application of the principle of tolerance in the UAE. This policy was laid down by the founder President of the UAE, the late Sheikh Zayed bin Sultan Al Nahyan who stressed that foreign aid and assistance is one of the basic pillars of UAE foreign policy. (UAE Government n.d.)

The Emirates constantly boast about meeting the UN Millennium Development Goals in eradicating extreme poverty, while conferring pledges to alleviate the suffering of the Yemeni people. However, just pouring money into the same countries that they themselves have been shelling is not enough to win the hearts and minds of the international audience. That, of course, is not to say that Abu Dhabi bears the sole blame for the misfortunes of Yemen. Given their common fear of Iranian intentions in the wake of the Houthi takeover of the capital Sanaa in 2014, the UAE were invited by the Saudis to participate in their military campaign in order to restore the status quo ante. Whereas it is true that the Emirates were driven by their own regional aspirations, it would have been inconceivable for these two Gulf Arab powers to leave Iranian interference in the Peninsula unchecked. Despite the fact that Tehran denies it, a 2018 UN report indicated that the Houthis were supplied with military material emanating from the Islamic Republic (Fahim 2018).

In the midst of that new proxy conflict, the question of reputation, which is of crucial significance in public diplomacy, inevitably came to surface. Much like the USA during the Iraq War, whose crusade in exporting democracy was overshadowed by the inhumane treatment of prisoners in Abu Ghraib and Guantanamo (Nye 2019, p. 11), the Emirates are still haunted by the images of the famine-stricken children that went viral on social media during the Saudi-led Yemen campaign, in addition to UN allegations of committed war crimes and evidence of secret detention centers (Human Rights Watch 2018, World Report 2019). The Houthis also face war crime charges, such as diverting food aid or sending child soldiers to battle (BBC NEWS 2018; Human Rights Watch 2015). To make matters worse for the Emirati international image, the embattled Yemeni President, Mansour Hadi, accused the Crown Prince of Abu Dhabi, Mohammed bin Zayed of 'behaving like an occupier of Yemen, rather than its liberator' (Hearst 2017).

For this reason, pledges to the reconstruction of the war-torn countries and declarations on peace, tolerance and women empowerment in the Middle East and Africa (UAE The Cabinet n.d.b) must be viewed in tune with UAE efforts to create 'soft power', which is, according to Nye (2019, p. 11), the outcome of successful public diplomacy. By reinterpreting religious tradition on the basis of tolerance, openness, interfaith dialogue and moderation, the UAE do not try to sell, in Nye's words, 'an unpopular product' (p. 13), e.g., their policies in Yemen (Ghaith 2018), but rather to downplay the atrocities, the crackdowns on dissidents and the reported abuses of migrant domestic workers from India, Nepal, Indonesia, Sri Lanka, the Philippines, etc. (Human Rights Watch 2017). At the same time, the country improves its world profile and raises its credibility in international relations.

The ideological utilization of Islam, of course, is not a novelty. Both Islamic heritage and the Arabic language have traditionally predominated Arab cultural diplomacy to meet political ends; the Algerian National Liberation Front ruling party imported Azharite graduates from Egypt to reinforce the postcolonial state's Arab Islamic identity (Stora 2001, pp. 148, 171; Mansour 2005, pp. 275-81), Abd al-Naser justified nationalizations and land redistribution on religious grounds (Rahman 1982, pp. 88-89), whereas Saudi Arabia used the think-tanks of Salafists and self-exiled Islamists against Panarabism and Naserism and, later on, Iranian Shiite revolutionarism (Vassiliev 1998, pp. 469-72). Today, the international outcry provoked by the Islamic State in Iraq and Syria (ISIS) terror attacks in Europe, as well as, its heinous acts in the Middle East, such as beheadings and purges against religious groups, provided an opportunity to countries like the Emirates or Indonesia to redesign their public diplomacy by defending 'true Muslims' and 'true Islamic tradition' on behalf of the Arab and Islamic worlds (Hoesterey 2016).

The warm reception of 'moderate Islam' rhetoric lies in the historically cordial relations between the UAE and the West, which have been shaped by shared interests and security concerns. After the 
British withdrawal from the Gulf, the country received for the first time American military material in 1977 (Sirriyeh 1984, p. 111); throughout the decades that followed the collapse of the Shah's regime, Emirati military buildup has reached unprecedented levels by virtue of the monarchy's geostrategic value in containing revolutionary Iran and al-Qaida alike (Young 2013). It is no wonder that the UAE wholeheartedly participated in the international coalition's fight against the Islamic State. In the meantime, their partners in the West turned a blind eye in respect to their acts in Yemen. After the Charlie Hebdo attacks, the Emirati foreign minister was among the first Muslim personalities who rushed to Paris to condemn the Jihadists and attend the rally of the world leaders (Tran 2015).

It was not until 2018 that some of the country's arms suppliers, like Germany, Norway, Austria, Denmark, Finland, the Netherlands, and, to a lesser extent, Sweden voiced their criticism over the war crimes that their Arab allies had allegedly committed in Yemen and imposed bans and restrictions on exports of military material (Westall 2019). Although the legal framework exists (EU Common Position on Arms Exports of 2008 and the Arms Trade Treaty of 2014), the position of the West towards that matter has been neither unanimous nor clear due to the lucrative contracts of the defense industries that lobby on behalf of their clients. The UK adopted a rather ambivalent stance, while French officials acknowledged that they have never ceased to provide Abu Dhabi and Riyadh with the latest weaponry in the name of fighting al-Qaida in the Arabian Peninsula (Mielcarek 2019). Hence, 'moderate Islam', in its own right, could be a useful public diplomacy tool in improving biased Western European perceptions of the Emirates.

As for the United States, they represent the UAE's major ally and strategic partner. After 9/11, they have been always receptive to their Muslim partners' 'moderate Islam' diplomatic initiatives, irrespective of human rights violations or their interventions in Yemen and elsewhere. Against the background of deteriorating US-Iranian relations in the post-Obama era, the circumstances have been favorable for the Emirates to project their model of 'moderate Islam' as a positive force capable of containing all forms of extremism. The various anti-terror pacts signed by the Trump administration and the Arab monarchs since 2017 set the geopolitical context for the Emirati 'moderate Islam' public diplomacy, which is examined at length in the lines that follow.

\subsection{Putting UAE Public Diplomacy to Test}

Taking into consideration the three dimensions of public diplomacy, i.e., news management, strategic communication and building long-term relationships with key individuals and populations (Leonard et al. 2002, p. 10), we could claim that all of them apply to the UAE 'moderate Islam' campaign, though with different degrees of success.

In the first place, even though the Emirati government tightly controls domestic media and promotes its peace and tolerance initiatives on Facebook and Twitter, it is impossible to distract regional and international attention from daily discussions about Yemen in light of the UN and Amnesty International reports implying Abu Dhabi's direct involvement in war crimes during the period 2016-2018 (Bruce 2018). For instance, to the accusations of unjustifiably killing thousands of civilians, including children, by targeting school buses, funerals and weddings, the UAE usually respond with ministerial tweets and press releases about the peaceful coexistence of the country's religious communities, sharing photos of newly erected churches or Hindu temples on their official social media pages. Despite scaling down their military presence since the summer of 2019, war information on Twitter continues and the UAE certainly lost most of its battles (Emirates Leaks 2019). On top of that, Emirati public diplomacy lacks a tool of the size and impact of Al-Jazeera that would be essential for shaping Arab and Western public opinion on current matters (Samuel-Azran 2013). This proved to be a major setback, especially since the Saudi-Emirati rift with Qatar in 2017. Al-Jazeera releases videos on its social media about Riyadh's and Abu Dhabi's role in the 'world's worst humanitarian crisis' (Gathmman 2019), whose negative impact cannot be easily reversed.

Abu Dhabi has been more skillful in creating 'soft power' as far as strategic communication is concerned. This second dimension of public diplomacy regards managing international perceptions 
of the country as a whole through the mediation of several agencies and actors working in unison (Leonard et al. 2002, pp. 14-15); according to Nye (2019, p. 12), governments organize campaigns, like the 1980s peace movement diplomacy of the Soviets, that revolve around central themes and values and plan events such as conferences, partnerships, festivals, etc. to reinforce them. The goal of such a strategy is to affect international opinion in the long run. In recent years, the Gulf monarchy, indeed, has been quite active in its national rebranding along the lines of 'moderate Islam', as the Emirati Ambassador in the US, Yousef al-Otaiba, claimed in his CNN (Cable News Network) interview:

Divisiveness and polarization are on the rise across the world, and-if left unchecked-this trend will undermine global stability and peace. The UAE is pushing against this rising tide by creating a model that can serve as a road map for others to promote greater tolerance and openness. Unique government policies, innovative partnerships and interfaith dialogues are three of the ways the UAE is leading by example. (Otaiba 2016)

The cornerstone of Abu Dhabi's strategic communication is the so-called 'Forum for Promoting Peace in Muslim Societies' (PEACEMS), which has been held five times since 2014. The first session's goals were outlined as follows:

(a) Reviving the spirit of coexistence that used to preside in Muslim societies;

(b) Reviving the humanistic values among all religions;

(c) Resorting to scientific methodologies in order to correct distorted views on religion;

(d) Encouraging the Ulema to preach tolerance and peace;

(e) Enhancing the role of the United Arab Emirates in spreading peace, security and prosperity in Muslim and non-Muslim societies alike (PEACEMS 2014).

By referring to several Quranic verses (The Holy Quran 5:2; 8:1; 49:13; 2:269; 7:170; 16:90; $21: 107 ; 39: 10)$, the Forum defines the 'true Islamic' values, such as tolerance (al-tasāmuh), compassion (al-rahma), reform of the self (islāh al-dhāt), justice (al-'adl), patience (al-sabr), solidarity (al-tadāmun) and religious centrism (al-wasatiyya). The UAE embassy in the US plays a vital role in rebranding Islamic values as the 'original' Emirati ones:

The UAE has a new vision for the Middle East region - an alternative, future-oriented model that supports moderate Islam, empowers women, embraces diversity, encourages innovation and welcomes global engagement. These values have been ingrained in the UAE's DNA since the country's founding in 1971. It explains why over 200 nationalities call the UAE home and why different religions have built approximately 40 churches, two Hindu temples, a Sikh temple and a Buddhist temple, which welcome multi-national congregations. (Embassy of the United Arab Emirates 2019b)

Undoubtedly, international conferences constitute a powerful asset in public diplomacy. Together with the Moroccan dynasty, the Emirates provided their valuable 'know how' in holding the Conference for the Rights of Religious Minorities in Predominantly Muslim Lands in Marrakesh, in January 2016. The Conference resulted in the famous Marrakesh Declaration-the purpose of which is to alleviate Western concerns over the fate of non-Muslims in Muslim societies (Marrakesh Declaration 2016). Central themes in Islamic tradition and historiography such as the Charter of Medina-a document referring to Prophet Muhammad's contract with the people of Medina who offered him shelter after the Hijra (622 AD) - are reinvented under the prism of present-day minority issues, interfaith dialogues and common counter-extremism efforts. Another such event is the World Tolerance Summit that is hosted by Dubai every November, since 2018, in conjunction with UNESCO's International Day for Tolerance (16 November). Its first session was attended by 1866 participants from 105 countries around the world (Al-Shaibani 2019).

Strategic communication, though, is not limited to annual forums and conferences. Over the last five years, the government enacted a variety of laws and policies aiming to institutionalize the 
concept of tolerance at home, while exporting the 'Emirati model' abroad. Just to mention a few, a Ministry of Tolerance has been established (Al-Zayani 2016); the National Program for Tolerance was launched in 2016, praising Emirati Islam and culture as 'truly moderate' (UAE The Cabinet n.d.c). In 2017, the-first of its kind in the Arab world-International Institute for Tolerance was founded by the country's PM, Sheikh al-Maktoum and, in late 2018, the Emirati President, Sheikh Khalifa al-Nahyan, announced the National Research Project on Tolerance, reminding the world that his country 'is now a global beacon of civilized behavior' (Khamis 2018).

The third dimension of public diplomacy is identified as relation building; this process takes place either through the mediation of key personalities (religious leaders, thinkers or politicians) or at the level of populations who work, study, participate in cultural exchange or simply visit the country under question. Just like Margaret Thatcher, Helmut Schmidt or Anwar Sadat, who, according to Nye (2019, p. 13), 'adopted and promoted American values, after having been educated in US institutions', the UAE seek to influence future Arab leaders by instructing them on their own tolerant values. The seminars and courses taught in the Mohammed Bin Rashid School of Government are indicative of Emirati intentions to exercise public diplomacy through educational programs (Mohammed Bin Rashid School of Government n.d.).

Furthermore, Abu Dhabi set up a special relationship with two prominent religious figures: Pope Francis and the Grand Imam of al-Azhar, Doctor Ahmad al-Tayeb. Sheikh al-Nahyan visited Pope Francis in 2016 and then the Pontiff repaid the visit in February 2019. During his historic speech in front of more than 150,000 people, the Pope commented on the war in Syria and Yemen in a rather ambiguous way; the serious accusations concerning Abu Dhabi's deep indulgence in the humanitarian crisis of Yemen did not prevent Pope Francis from whitewashing his hosts' alleged war crimes, when he stated that 'the UAE are a modern country and an open society to dialogue that educate its children by looking forward' (Barbarani 2019). Concerning the Grand Imam of al-Azhar, he was singled out thanks to his influential status in the Sunni world; he had already met Pope Francis at the latter's visit to al-Azhar in 2017 and all Muslim autocrats consider him an indispensable interlocutor. During the Pope's UAE visit, he was invited to cosign the 'Human Fraternity Document' with the Pontiff (Associated Press 2019). Consequently, the UAE capitalized on the presence of those high-profile personalities to create 'soft power' via interfaith dialogue diplomacy.

At the level of peoples' public diplomacy, Leonard stresses the need 'not just to develop relationships but to ensure that the experiences which people take away are positive and that there is follow-up afterwards' (Leonard et al. 2002, p. 18). This can be true for a country like the Emirates, where more than 80 percent of the country's population according to 2019 data consists of Indian, South Asian, European and other expatriates (United Arab Emirates Population Statistics 2019). Constructing new places for worship and protecting the rights of every faith are adequate reasons to keep non-Muslims content. In 2017, in a strongly symbolic and rather spectacular gesture, Sheikh Mohammad bin Zayed Mosque in Abu Dhabi was renamed to Mariam Umm Eisa, honoring the mother of Jesus. Hence, it is no wonder that American pastors publish articles praising the tolerant, multireligious Emirati society:

Different religions have built 40 churches, two Hindu temples and a Sikh temple, all on land donated freely by the ruling authorities, who welcome multi-national congregations in the UAE. The region's largest Anglican Church is currently being built in Abu Dhabi and will accommodate more than 4000 worshipers once complete. (Reverend et al. 2018)

\subsection{Containing the Threat of Political Islam}

In this chapter, it is examined how 'moderate Islam' serves as a tool of 'sharp power' in terms of containing the perceived or real threat of Political Islam. Reading between the lines of the abovementioned interfaith partnerships, as well as the declarations on tolerance, moderation and peaceful coexistence, it is argued that Abu Dhabi's and Dubai's rulers do not consider the fanatics of ISIS or al-Qaida per se to be their real enemies. Taking into account the UAE socio-political structures, the actual threat emanates from activists who not only ask for more liberties but also question the 
royal absolutism. As the modern history of the Arab world has shown us, political dissidence in these countries is predominantly Islamist ${ }^{1}$ in nature. During the third annual session of the PEACEMS forum in 2016, participants confirmed that:

Our greatest concern is to shed light on the political outcomes that stem from the distortion of the Islamic Sharia ( . . ) interpreting the teachings of our religion out of their original context has given the necessary pretexts to forces threatening social peace in Muslim societies, specifically those who are still trying to recover from regime change, meanwhile other forces have even attempted to reshape international order and replace the nation state with their self-declared 'Islamic Caliphate'. There is no parallel in these entities' usurpation of religious symbols and terminology. (PEACEMS 2016)

The previous passage directly refers to the Islamic State in Iraq and Syria in addition to Egypt's Muslim Brotherhood experience, castigating the subversive role played by the Islamists every time they have meddled with politics. What is even more interesting, though, is how the Emirati 'moderate Islam' campaign demonizes Islamists of all stripes. In other words, under the pretext of 'distorting Sharia and the teachings of religious tradition', non-militant Islamist parties committed to democracy, elections and socio-political reform are easily equated with Osama bin Laden, the Taliban or Abu Bakr al-Baghdadi. As one Emirati writer puts it 'Islam has been hijacked by the Islamists and should be reclaimed by the forces of moderation' (Al-Sawafi 2014). The whole campaign is reminiscent of the post-9/11 USA neoconservative 'bad and good Muslim' rhetoric.

Regionally, this anti-Islamist strategy has a twofold target, bearing ideological, religious and geopolitical implications: disparaging the well-organized, transnational Muslim Brotherhood (al-Ikhwan), while counterbalancing Qatar-another regional player whose small size did not prevent it from resorting to 'hard power' diplomacy after 2011 (Nuruzzaman 2015, pp. 226-29). In order to put the UAE 'ikhwanphobia' into context, we should first have a brief look at the Islamist movement's political evolution in the Middle East and North Africa (MENA) and the Gulf in particular.

Most of the times during its turbulent history, the Brotherhood was either tolerated by the post-colonial state or persecuted, depending on the domestic situation, on the reevaluated regional policies of the Arab countries and on their shifting alliances. During the 1970s and the 1980s, some splinter Brotherhood groups, like al-Jamā 'a al-Islamiyya, elaborated the idea of Takfîr (excommunication of Muslims) and waged Jihad against the Kuffār, i.e., the perceived 'infidels' who ought to be fought and killed either at home or abroad (Keppel 1985, pp. 71-91, 194-210; Pargeter 2010, pp. 181-85). The emergence of such extreme currents has been a mixed blessing; on the one side, it enabled the 'loyal' Brotherhood leaders to redefine themselves as 'moderates', while whitewashing their own socio-political conservatism and illiberal stance on issues like the segregation of sexes. On the other, this very fact justified harsh state suppression of Islamism sui generis. With a few exceptions like Syria, where the Brothers tried to topple the government by force in 1982, in other countries like Egypt, Jordan, Morocco, Kuwait or Yemen, they remained committed to charity and preaching (Clark 2004, pp. 42-145). During the last 30 years, the would-be 'moderate Islamists' formed

1 As Islamists (al-islamiyeen) are defined those Muslims who consider Islam to be a complete socio-political and economic system, as well as, a cultural program, rather than a religion that is concentrated solely on spiritual matters. For this reason, analysts tend to use the term Political Islam and Islamism interchangeably. The historical matrix of this modern ideology was the Egyptian Muslim Brotherhood and the writings of its founder, the school teacher Hasan al-Banna (1906-1949). The evolution of Islamism has gone part and parcel with the political and social development of the Arab and the Muslim nation-states throughout the 20th century. Some groups of Islamists turned out to be extremely militant, engaged in terrorist attacks against Muslims and non-Muslims alike and even attempted to overthrow governments via armed revolts, whereas other groups respected central authorities and generally espoused non-violence. In terms of European political standards, those Islamists could be described as socially conservative and economically liberal, i.e., the 'Islamic equivalent' of Christian democratic center-right parties. An Islamist party (Al-Nahda) has been part of the Tunisian governing coalition for many years, while AKP, Erdogan's ruling party, is also considered Islamist in its ideology and origins. In Egypt, although the Muslim Brothers won parliamentary and presidential elections in 2012, they demonstrated illiberal tendencies in order to secure their rule. 
parties and even elected their own deputies in national parliaments or participated in governments (Anani 2010, pp. 1-6).

Undeniably, the watershed in the organization's political fortunes was the Arab Spring. In the aftermath of the Tahrir Square uprisings, Egyptian Islamists won two consecutive elections, both parliamentary and presidential. The association founded by a humble school teacher 84 years ago had become the protagonist of the most pivotal Arab country's political transition. Islamist rule in Egypt was a reality, albeit a short-lived one. Mass protests, new alliances on the streets among those who were sidelined by the Brotherhood, not to mention relentless foreign interference, boiled down to Morsi's downfall. The Islamist cabinet and President Morsi were accused of incompetence, favoritism and autocratic tendencies; these claims are verified to some extent, considering the illiberal and socially conservative constitution that had been brought to popular vote (Hamid and Wheeler 2014). The country was at the brink of civil war when Abdel Fattah al-Sisi's 2013 3rd July coup took place, allegedly to 'save the 25th January revolution from the Islamists who hijacked it' (Kourgiotis 2014).

The sudden perish of the Muslim Brotherhood in its own birthplace echoed the post-Arab Spring contest for power among the Gulf Cooperation Council countries, which were alarmed by the Islamists' electoral victories and bitterly divided over their reactions towards them. We should keep in mind that by the time of the Arab uprisings, Brotherhood-affiliated Islamists had already established their presence in the Gulf countries dating back to the first purges under Naser (1952-1970). Thousands of Brotherhood members contributed in the social and educational development of the Arab Gulf and, as a matter of fact, they infiltrated those countries' nascent universities. The Emirati Brotherhood particularly had grown so powerful in Abu Dhabi's only university that, by the late 1980s, it was in a position to approve or reject the federal government employees' applications to the scholarship committee (Al-Rashid 2013).

Over all these years, relations between the Brothers and their wealthy hosts in the Gulf were based on a simple 'social contract': shelter for da 'wa (preaching) in exchange for refraining from politics. Younger generations, nonetheless, were influenced by the Brotherhood's ideological reorientations and started talking about political reform even inside the less liberal kingdoms. That is the case of the 1990s al-Sahwa al-Islamiyya (Islamic Awakening) in Saudi Arabia, as well as Da 'wat al-Ișlāh (Call for Reform), or simply al-Ișlāh, in the Emirates. Not surprisingly, after starting monitoring Ikhwani activity in the universities and elsewhere, the UAE authorities demanded from al-Islāh to cut its organic ties to the mother organization in Cairo (Freer 2015a, pp. 11-3, 18-20; Al-Rasheed 2002, pp. 176-83; Lacroix 2011, pp. 37-80). The Emirates had enough good reasons to feel threatened by the Brothers, because they left their activities unchecked for two decades at least.

On the contrary, the al-Thani dynasty of Qatar felt no existential threat to its rule by the Brotherhood influences in this tiny kingdom, because as Grabowski states 'Emir Hamad al-Thani left no space for the Brothers to gain support through social services, creating jobs etc.' (Grabowski 2016, p. 358). The Emir Tamim bin Hamad al-Thani and his father before him, in that movement's capabilities to fill the vacuum left by the demise of the Arab autocrats, they saw a golden opportunity to maximize Qatar's regional standing (Roberts 2014). Erdogan's government acted in full conformity with al-Thani dynasty in creating a chain of 'loyalist Islamist republics' across the Arab world on behalf of 'the oppressed people' as the Turkish President has declared publicly (Daily 2014). Accordingly, Egypt, during the short term of Morsi's rule, received eight billion US dollars from Doha (Kerr 2013). In the same vein, Qatar extended its support to the Tunisian Islamist party Ennahda that dominated the 2011 constituent assembly following the country's first free elections and kept backing financially the post-2014 coalition government, much to the dismay of Abu Dhabi (Cherif 2017).

The Saudis and the Emiratis feared that, had the Ankara-Cairo-Doha axis remained intact, it would have probably emboldened the rest of the region's Islamists, including their own, to demand reforms, elections, etc. (Fajri 2013). As soon as Hosni Mubarak was deposed, Hizb al-Ummah al-Islami, the first political party in Saudi Arabia, had already been banned after a very brief 'Saudi Spring' (The Islamic Ummah Party n.d.). As for the UAE, anti-ikhwanism reached new heights; as early as 
2011, members of al-Iṣlāh joined forces with liberal non-Islamists and signed a petition requiring universal suffrage, legislative authorities for the Federal National Council ${ }^{2}$ and broader constitutional reforms (Freer 2015b). A year later, Emirati authorities discovered an alleged coup attempt. According to Emirati sources, 60 Brotherhood affiliates were arrested and charged with plotting against the federal government (The National 2012). Al-Nahyan ruling dynasty referred to an 'international Brotherhood conspiracy coordinated by neighboring countries', although President Morsi had repeatedly reassured the Arab leaders that 'Egypt had no intention of exporting its revolution' (Saleh and Hall 2012).

This Emirati version of 'McCarthyism' has led to the diplomatic standoff with Qatar, crises with the UK and other European countries due to their reluctance to designate the Brotherhood as a terrorist group and even to a severance of relations with their protégé, the Yemeni President, because of his ties with the local Ikhwanis, namely the al-Islah party (Cafiero 2018). It is worth mentioning that some UAE based academics from Europe or the US try to apologize for their hosts' 'ikhwanphobia', arguing that the Brotherhood's ideology runs counter to the country's 'moderate Islamic' model. They reiterate that authorities have clamped down only on the Brotherhood-affiliated activists and that non-Islamist dissidents who call for reforms are generally tolerated (Forstenlechner et al. 2012). Such claims are rather dubious. In the meantime, the UAE government acknowledged that the 'Islamist threat' has been graver in the poorer northern emirates and pledged to abolish inequalities in the distribution of the wealth, implementing the goals set by the Dubai 2021 Plan (Moshashai 2018, pp. 21-22).

Apparently, Saudi Arabia and the UAE had a strong interest in interfering with Egypt in the wake of the 2013 anti-Brotherhood protests. According to leaked Saudi cables, the two Gulf partners favored what has been known as the 'Pakistani model' (Royal Embassy of Saudi Arabia in Cairo 2012), i.e., supporting military strongmen and cultivating relations with local religious authorities. This is exactly the same counter-revolutionary scenario that they tried to impose in Libya through General Haftar's offensive against Tripoli's Islamists. Regardless of investing billions of dollars so as to outflank Qatari influences and help Sisi stabilize his regime (Farouk 2014, pp. 10-13), 'healing' the Muslim Brotherhood 'disease' is not just a question of money; an effective 'medicine' had to be found, combining coercion, aid policies and-most importantly-ideological 'rehabilitation'.

Whereas the Saudis invested in their loyalist Salafists of Hizb al-Nour as a means to avert the pious masses from the Ikhwan (Kourgiotis 2016, pp. 13-21), the UAE took advantage of Egyptian 'recovery' from Political Islam to initiate their 'moderate Islam' policies. The contribution of al-Azhar University can be considered critical to the common cause of 'reclaiming Islam' and containing the Ikhwanis whether in Egypt or the Gulf. Historically, in the Sunni lands, the Ulema intervened in the production of religious tradition at the behest of central authority, no matter whether they were the Caliphs, the colonial empires or today's nation states. At the request of the UAE rulers, Islamists were portrayed by the Ulema as 'sick people' who needed 'immediate treatment':

The forum's biggest concern revolves around how religious fanaticism and terrorism will be defeated in the hearts of the people before materializing into actions ( ... ) it is the duty of the Ulema, the governments and other institutions to instruct Muslims on the proper forms of religiosity and religious behavior $(. .$.$) there is no doubt that our Islamic pharmacy is able$ to prescribe the right medication to the patients in order to get rid of the disease of violence once and for all. (PEACEMS 2014)

In the passage of the last five years, the Emirati-Azharite partnership came to the surface as the bastion of 'moderate Islam'; an alternative to both Ikhwanism and Salafism. The Egyptian President, Sisi, has

2 The UAE parliament consists of 40 members-20 of them are elected every 8 years, while the rest are directly appointed by the Ruler's Court in every Emirate. Its authority is mostly consultative and not legislative, given the fact that it has the right only to review the laws presented to it by the Cabinet. No federal law can pass without the final approval of the Emirati Cabinet. Available online: https://www.government.ae/en/about-the-uae/the-uae-government/the-federal-national-council(accessed on 16/11/2019). 
been cautious enough to undertake a national campaign of fighting atheism, while pressing al-Azhar to revise its curricula in the direction of al-wasatiyya (religious centrism) and apply scrutiny on suspicious fatwas (Ibrahim 2014; Mourad and Bayoumi 2015). After the ordeal in Bataclan, Al-Azhar even asked the French government to send its imams to teach French Muslims 'moderate Islam' (France24 2015). In the 2016 Grozny conference, the UAE together with al-Azhar and Russia redefined what Sunni Islam 'ought to be' and irritated the Saudi Ulema by excluding Salafism as intolerant and prone to Takfīr. The invitation of the Grand Mufti of Syria was a sign of the Emirati-Egyptian intentions to co-opt another staunch enemy of the Ikhwan, Bashar al-Assad (Diwan 2016). The Emirates for their part, organized a series of lectures delivered in the mosques of Dubai, throughout 2019, highlighting Islam's moderate stance on scientific, social and religious topics (Gulf News 2019).

From every aspect, 'religious rehabilitation' supplements the politics of containment. All those years of instructing Muslims on how to 'properly express their religiosity' has taken place in parallel to the Emirati airstrikes against the 'Caliphate' in Syria and Sisi's efforts to eliminate the Jihadist insurgency that his regime was constantly facing in the Sinai Peninsula from the very beginning. The UAE leadership intensified its security cooperation with the new Egyptian government and, at the same time, it took preemptive measures at home, such as the Anti-Terrorist Crimes Laws No. (7) and No. (9)/2014, the Anti-Hatred and Anti-Discrimination Law No. (2)/2015 and the Tolerance Law No. (9)/2017 (UAE The Cabinet n.d.d; Hamdy 2018). Moreover, two counter-terrorism centers, namely al-Hedayah (Guidance) and al-Sawab (Right), were established to eradicate Da 'esh ideological imprints on the Muslim youth (Sky News Arabiyya 2015).

Once again, the Jihadist threat proved to be a very convenient alibi; in terms of internal security, it justified the expansion of the UAE anti-Islamist crusade so as to include any kind of opposition. For one thing, Abu Dhabi's first PEACEMS gathering of Sunni Ulema from around the globe to discuss de-radicalization coincided with the public circulation of a list of 85 terrorist organizations including al-Ișlāh and all the regional branches of the Muslim Brotherhood. The Emirates went as far as to target legally registered Islamic Associations and NGOs (Non-Governmental Organizations) tolerated by the US and European authorities on the grounds of disseminating dangerous Ikhwani ideology (Gulf News 2014). In the same year, the Council of Muslim Elders was founded in Abu Dhabi and the Grand Imam of al-Azhar was appointed as its chairman (Muslim Council of Elders n.d.). The Council functions as a counterweight to the Doha-based International Union for Muslim Scholars headed by the Brotherhood Imam and al-Jazeera TV star, Yussef al-Qaradawi (International Union for Muslim Scholars n.d.). Fierce theological battles have been fought between the two bodies ever since. Time will tell whether the UAE will remain the staunchest anti-Brotherhood power in the region even in light of a future rapprochement with Qatar.

Despite 'moderate Islam's' bias towards Salafists, the two models share the same quietist approach, i.e., de-politicize Islam as a way of de-radicalizing Muslim youth; in their view, the tolerant Muslim should be the apolitical ones. Similar initiatives were launched after the 9/11 terror attacks, like the Commonwealth Office's program 'Projecting British Islam'. Even if they failed to prevent the 'Hijrah' of European Jihadists, such programs have always been appealing to the insecure Arab dictators (Mandaville and Hamid 2018, pp. 2-8). By 'reclaiming Islam' from the Islamists, the state power reasserts its monopoly on the use of religious symbols, discourses and Quranic interpretations; Jihad and the Sharia are incorporated in the policies of the nation state. What is more, several regimes shield their immunity to potential political change.

In conclusion, from 2014, the UAE underwent a new nation-building process that illuminated the necessity to 'instill tolerance in the Emirati national consciousness' and 'forge future tolerant generations among the country's youth' (UAE Ministry of Tolerance n.d.). In that sense, 'true Islamic values' are restored for the society's sake, whilst Islamist and non-Islamist dissidents alike are ostracized as 'the enemies of religion and the motherland'. 


\section{Conclusions: Caught between 'Soft' and 'Sharp Power'?}

This essay presented a detailed account of how the top-down project of 'moderate Islam' has redefined the UAE's international image as well as their post-Arab Spring regional policies. Time and again, colonial and postcolonial authority did not resist revisiting religious tradition under the pressure of external or domestic challenges. The Emirates' policies fit that historical pattern. The article concludes that, via their campaign, the UAE engaged with 'soft' and 'sharp power' alike. Throughout our presentation, we analyzed how religious tolerance has been utilized to whitewash domestic political intolerance and aggressive interventionism in other countries' internal affairs.

With respect to public diplomacy, the joint de-radicalization efforts between the Emirates and al-Azhar are deemed as exemplary tactics in creating 'soft power'. Public opinion, of course, has not forgotten Yemen, or the Emirati occupation of some parts of this country, yet the UAE leadership managed to rebrand itself as one of the world's earnest backers of interfaith dialogue and redirect the agenda to its favor. Pope Francis' visit stands as a testimony to the success of such diplomacy. Moreover, thanks to 'moderate Islam', the small Gulf monarchy re-emerged in international relations as a model exporter; following Abu Dhabi's lead, even the Saudi Crown Prince, Muhammad Ibn Salman, appears determined to reintroduce 'moderate Islam' in his ultra-conservative kingdom, in line with Riyadh's Vision 2030 (Kingdom of Saudi Arabia n.d.).

However, due to growing security concerns, the Emirates had to resort to what Nye calls 'sharp power' (Nye 2019, p. 17), such as funding anti-Brotherhood parties and militias, backing coups and disseminating conspiracy theories to discredit opponents. These practices are identical to US anti-communist activities during the Cold War and on no account produce 'soft power'. Perhaps, the UAE could be better compared to the Chinese model that rests on 'soft power' campaigns, e.g., ecological issues, climate change, etc., whilst crushing dissidents and ethnic groups in the interior (Nye 2019, pp. 18-19). Against the backdrop of increased calls for reforms, whether social, economic and, to a lesser extent, political, 'moderate Islam' endorses and legitimizes the status of the UAE monarchy by casting out opposition as 'intolerant' and consequently, 'unislamic'. Emirati policies will continue to be caught between 'soft' and 'sharp power' owing to authoritarian tendencies, unless bold constitutional reforms are instigated under mounting social pressure. This is a potentiality that does not fit into the monarchy's 'success story' for the time being.

Meanwhile, the monarchy is represented in the eyes of the US and some other Western partners as an 'enlightened model' for the rest of the region, despite the debates that have sparked in the parliaments of the UK, France, Germany, Sweden and elsewhere regarding the situation in Yemen. According to the Dubai 2021 Plan, the Abu Dhabi 2030 Vision and many others (UAE The Cabinet n.d.e), the ruling families aspire to transform the Emirates into a global hub of market economy, green growth and tolerance. This is the climax of the UAE rulers' public diplomacy indeed, notwithstanding that they could hardly tolerate political openness out of fear that it would backfire and cost them their centuries-old grip on power. As far as their Arab and Muslim audiences are concerned, the Emirati rulers are cautious enough to remind them that far from assimilating 'alien, Western values', they simply rediscover the Islamic Golden Age (9th-12th centuries) and revive the legacy of Damascus, Baghdad and al-Andalus.

Funding: This research received no external funding.

Conflicts of Interest: The author declares no conflict of interest. 


\section{References}

Abdulrahim, Raja. 2019. Foreign Backing Brings Militias in Libya to a Stalemate-and No Further. The Wall Street Journal. October 1. Available online: https://www.wsj.com/articles/foreign-backing-brings-militias-in-libyato-a-stalemateand-no-further-11569942469 (accessed on 12 October 2019).

Al-Azami, Usaama. 2018. UAE's Forum 'for Promoting Peace' Is Another Cynical PR Initiative. Middle East Eye. December 4. Available online: https://www.middleeasteye.net/opinion/uaes-forum-promoting-peaceanother-cynical-pr-initiative (accessed on 9 October 2019).

Al-Rasheed, Madawi. 2002. A history of Saudi Arabia. Cambridge: Cambridge University Press.

Al-Rashid, Abdullah. 2013. The Brothers and the Emirates. Majalla. February 14. Available online: https: //eng.majalla.com/2013/02/article55238281/the-brothers-and-the-emirates (accessed on 16 November 2019).

Al-Sawafi, Muhammad Khalfan. 2014. Al-Imarat wa-l-Islam al-Mu 'tadil (The Emirates and the Moderate Islam). Al-Ittihad. March 19. Available online: https://www.alittihad.ae/wejhatarticle/78051/\%D8\%A7\%D9\%84\% D8\%A5\%D9\%85\%D8\%A7\%D8\%B1\%D8\%A7\%D8\%AA--\%D9\%88\%D8\%A7\%D9\%84\%D8\%A5\%D8\%B3\% D9\%84\%D8\%A7\%D9\%85-\%D8\%A7\%D9\%84\%D9\%85\%D8\%B9\%D8\%AA\%D8\%AF\%D9\%84 (accessed on 14 November 2019).

Al-Shaibani, Hamdad. 2019. The UAE Embodies an Urban Model of National Unity and Tolerance. International Institute for Tolerance. May 26. Available online: https:/www.worldtolerancesummit.com/en-US/Media/ News/Dr-Hamad-Al-Shaibani-The-UAE-embodies-an-urban-mod (accessed on 3 November 2019).

Al-Zayani, Musaid. 2016. New UAE Ministries for Tolerance, Happiness, Future. ALSHARQ AL-AWSAT. February 11. Available online: https://eng-archive.aawsat.com/musaid-al-zayani/news-middle-east/newuae-ministries-for-tolerance-happiness-future (accessed on 4 November 2019).

Anani, Khalil. 2010. The Myth of Excluding Moderate Islamists in the Arab World. Paper No. 4. Washington, DC: The Saban Center for Middle East Policy at the Brookings Institution.

Associated Press. 2019. Pope: My UAE Trip Wrote New Page in Christian-Islam History. February 6. Available online: https://apnews.com/38e3d62fb264418a93135ba96c608339 (accessed on 6 November 2019).

Barbarani, Sofia. 2019. Pope Francis reflects on his UAE visit: I Saw a Modern, Welcoming Country. The National. February 5. Available online: https://www.thenational.ae/uae/the-pope-in-the-uae/pope-francis-reflects-onhis-uae-visit-i-saw-a-modern-welcoming-country-1.822408 (accessed on 6 November 2019).

BBC NEWS. 2018. Yemen War: WFP Accuses Houthis of Diverting Food Aid. December. Available online: https://www.bbc.com/news/world-middle-east-46722502 (accessed on 28 December 2019).

Bianco, Cinzia, and Gareth Stansfield. 2018. The Intra-GCC Crises: Mapping GCC Fragmentation after 2011. International Affairs 93: 613-35. [CrossRef]

Bruce, Nick-Cumming. 2018. War Crimes Report on Yemen Accuses Saudi Arabia and UAE. The New York Times. August 28. Available online: https://www.nytimes.com/2018/08/28/world/middleeast/un-yemen-war-crimes. html (accessed on 18 October 2019).

Cafiero, George. 2018. The UAE Campaign against Political Islam: Implications for London. Lobe Log. December. Available online: https://lobelog.com/the-uae-campaign-against-political-islam-implications-for-london/ (accessed on 17 November 2019).

Cafiero, George. 2019. Islam in the UAE's Foreign Policy. The New Turkey. March 7. Available online: https://thenewturkey.org/islam-in-the-uaes-foreign-policy (accessed on 8 October 2019).

Carvalho-Pinto, Vania. 2014. From 'Follower' to 'Role Model': The Transformation to the UAE International Self-Image. Journal of Arabian Studies 4: 231-43. [CrossRef]

Cherif, Yussef. 2017. Tunisia's Fledging Gulf Relations. Carnegie Endowment of International Peace. January 17. Available online: https://carnegieendowment.org/sada/67703 (accessed on 11 November 2019).

CIA The World Factbook. 2017. Available online: https://www.cia.gov/library/publications/the-world-factbook/ geos/ae.html (accessed on 4 October 2019).

Clark, Janine. 2004. Islam, Charity and Activism. Middle-Class Networks and Social Welfare in Egypt, Jordan, and Yemen. Bloomington and Indianapolis: Indiana University Press.

Daily, Sabah. 2014. Erdogan: We Side with Qatar to Support Oppressed People. December 19. Available online: https://www.dailysabah.com/politics/2014/12/19/erdogan-we-side-with-qatar-to-support-oppressedpeople (accessed on 14 November 2019). 
Diwan, Kristin Smith. 2016. Who Is Sunni?: Chechnya Islamic Conference Opens Window on Intra-Faith Rivalry. The Arab Gulf States Institute in Washington. September 16. Available online: https://agsiw.org/who-is-asunni-chechnya-islamic-conference-opens-window-on-intra-faith-rivalry/ (accessed on 19 November 2019).

El Yaakoubi, Aziz. 2018. UAE Extends Compulsory Military Service to 16 Months. Reuters. July 8. Available online: https://www.reuters.com/article/us-emirates-military/uae-extends-compulsory-military-service-to16-months-idUSKBN1JY093 (accessed on 12 October 2019).

Embassy of the United Arab Emirates. 2019a. Embassy of the United Arab Emirates, Washington DC. Foreign Policy. Available online: https://www.uae-embassy.org/about-uae/foreign-policy (accessed on 6 October 2019).

Embassy of the United Arab Emirates. 2019b. Embassy of the United Arab Emirates, Washington DC. Tolerance \& Inclusion. Available online: https://www.uae-embassy.org/about-uae/tolerance-inclusion (accessed on 4 November 2019).

Emirates Leaks. 2019. UAE Is Yemenis Enemy Hashtag Goes Viral on Twitter. November 8. Available online: https://emiratesleaks.com/en/uae-yemenis-enemy-hashtag-goes-viral-twitter/ (accessed on 9 November 2019).

Eno, Muhammad, Omar Eno, and Anthony Osambo. 2016. Harmonizing Globalization and Traditionalism in the Rentier State: Exploring the Modernization of the United Arab Emirates. International Journal of African and Asian Studies 25: 98-109.

Fahim, Karrem. 2018. U.N. Probe Details Fallout of Proxy War in Yemen between Saudi Coalition and Iran. The Washington Post. January 11. Available online: https://www.washingtonpost.com/world/un-probe-detailsfallout-of-proxy-war-in-yemen-between-saudi-coalition-and-iran-/2018/01/11/3e3f9302-f644-11e7-9af7a50bc3300042_story.html (accessed on 28 December 2019).

Fajri, Sufian. 2013. Kaifa Asbaha al-Ikhwan al-Halif al-Awal li-Qatar wa al-Khasm al-Akbar li-l-Saudiyya wa-1-Imarat? (How did the Brothers become Qatar's Best Allies and the Worst Enemies of the Saudis and the Emiratis?). France 24. February 14. Available online: https://www.france24.com/ar/20130214-\%D8\%A7\%D9\%84\%D8\%A5\%D8\%AE\%D9\%88\%D8\%A7\% D9\%86-\%D8\%A7\%D9\%84\%D9\%85\%D8\%B3\%D9\%84\%D9\%85\%D9\%88\%D9\%86-\%D9\%82\%D8\%B7\%D8\% B1-\%D8\%A7\%D9\%84\%D8\%B3\%D8\%B9\%D9\%88\%D8\%AF\%D9\%8A\%D8\%A9-\%D8\%A7\%D9\%84\%D8\% A5\%D9\%85\%D8\%A7\%D8\%B1\%D8\%A7\%D8\%AA-\%D8\%A7\%D9\%84\%D8\%B3\%D9\%84\%D8\%B7\%D8\% A9-\%D8\%A5\%D8\%B3\%D9\%84\%D8\%A7\%D9\%85\%D9\%8A\%D9\%8A\%D9\%86-\%D8\%A7\%D9\%86\%D8\% AA \%D8\%AE\%D8\%A7\%D8\%A8\%D8\%A7\%D8\%AA-\%D8\%B3\%D9\%84\%D9\%81\%D9\%8A\%D9\%8A\%D9\% 86-\%D8\%AE\%D9\%84\%D9\%81\%D8\%A7\%D9\%86-\%D8\%A7\%D9\%84\%D9\%86\%D9\%81\%D8\%B7-\%D8\% B9\%D8\%B1\%D8\%A8\%D9\%8A-\%D8\%A7\%D8\%B9\%D8\%AA\%D9\%82\%D8\%A7\%D9\%84\%D8\%A7\%D8\% AA-\%D8\%AE\%D9\%84\%D9\%8A\%D8\%A9-\%D8\%A7\%D9\%84\%D8\%AA\%D9\%86\%D8\%B8\%D9\%8A\%D9\% 85-\%D8\%A7\%D9\%84\%D8\%B9\%D8\%A7\%D9\%84\%D9\%85 (accessed on 13 November 2019).

Farouk, Yasmine. 2014. More than Money: Post-Mubarak Egypt, Saudi Arabia, and the Gulf. Paper. Jeddah, Geneva and Cambridge: Gulf Research Center.

Foley, Sean. 2002. What Wealth Cannot Buy: UAE Security at the Turn of the Twenty-first Century. In Crises in the Contemporary Persian Gulf. Edited by Barry Rubin. London: Frank Cass, pp. 33-74.

Forstenlechner, Ingo, Emilie Rutledge, and Rashed Salem Alnuaimi. 2012. The UAE, the 'Arab Spring' and different types of dissent. Middle East Policy 4: 54-67. [CrossRef]

France24. 2015. Al-Azhar musta 'id li-irsal a'ima mu'tadilin ila Faransa li-muajahati-l-mutatarrifin (Al-Azhar is Ready to Send Moderate Imams to France to Confront the Extremists). November 16. Available online: https://www.france24.com/ar/20151116-\%D9\%85\%D8\%B5\%D8\%B1-\%D8\%A7\%D9\%84\%D8\%A3\% D8\%B2\%D9\%87\%D8\%B1-\%D8\%A7\%D9\%84\%D8\%A5\%D8\%B3\%D9\%84\%D8\%A7\%D9\%85-\%D8\%A7\% D9\%84\%D8\%AA\%D8\%B7\%D8\%B1\%D9\%81-\%D9\%81\%D8\%B1\%D9\%86\%D8\%B3\%D8\%A7-\%D9\%87\% D8\%AC\%D9\%85\%D8\%A7\%D8\%AA-\%D8\%A8\%D8\%A7\%D8\%B1\%D9\%8A\%D8\%B3-\%D8\%AA\%D9\% 86\%D8\%B8\%D9\%8A\%D9\%85-\%D8\%A7\%D9\%84\%D8\%AF\%D9\%88\%D9\%84\%D8\%A9 (accessed on 19 November 2019).

Freer, Courtney. 2015a. Rentier Islamism: The Role of the Muslim Brotherhood in the Gulf. Paper No. 9. London: LSE Middle East Center. 
Freer, Courtney. 2015b. The Muslim Brotherhood in the Emirates: Anatomy of a Crackdown. Middle East Eye. December 17. Available online: https:/www.middleeasteye.net/big-story/muslim-brotherhood-emiratesanatomy-crackdown (accessed on 19 November 2019).

Gathmman, Sandra. 2019. Start Here/Why is Yemen at War? Video, 7:05, Posted by Al Jazeera English. November 3. Available online: https://www.facebook.com/aljazeera/videos/541461606654213/ (accessed on 5 November 2019).

Ghaith, Abdul-Ahad. 2018. Yemen on the Brink: How the UAE is Profiting from the Chaos of Civil War. The Guardian. December 21. Available online: https:/www.theguardian.com/news/2018/dec/21/yemen-uaeunited-arab-emirates-profiting-from-chaos-of-civil-war (accessed on 21 October 2019).

Grabowski, Wojciech. 2016. The Muslim Brotherhood and the Crisis in the GCC: Roots, Issues and Implications. International Relations 52: 355-66. [CrossRef]

Gulf News. 2014. UAE Publishes List of Terrorist Organizations. November 15. Available online: https: //gulfnews.com/uae/government/uae-publishes-list-of-terrorist-organisations-1.1412895 (accessed on 17 November 2019).

Gulf News. 2019. Dubai Pushes for Moderate Islam. August 20. Available online: https://gulfnews.com/uae/ government/dubai-pushes-for-moderate-islam-1.1566297297824 (accessed on 19 November 2019).

Hamdy, Hassan A. 2018. Head East! Toward a Security Alliance between Egypt and the UAE. In The United Arab Emirates Relations with Egypt. Edited by Hassanein Ali and Dar Al Khaleej. Sharjah: Gulf Center for Studies.

Hamid, Shady, and Meredith Wheeler. 2014. Was Mohammad Morsi Really and Autocrat? The Atlantic. March 31. Available online: https://www.theatlantic.com/international/archive/2014/03/was-mohamed-morsi-really-anautocrat/359797/ (accessed on 29 December 2019).

Hearst, David. 2017. Exclusive: Yemen President Says UAE Acting Like Occupiers. Middle East Eye. May 12. Available online: https://www.middleeasteye.net/news/exclusive-yemen-president-says-uae-actingoccupiers (accessed on 9 November 2019).

Hoesterey, James B. 2016. Rebranding Islam: Public Islam, Soft Power and the Making of Moderate Islam. Contending Modernities. April 20. Available online: https://sites.nd.edu/contendingmodernities/2016/04/20/aciindonesia-rebranding-islam-public-diplomacy-soft-power-and-the-making-of-moderate-islam/ (accessed on 18 November 2019).

Holmes, Amy Austin. 2014. The Military Intervention that the World Forgot. Al Jazeera America. March 29. Available online: http://america.aljazeera.com/opinions/2014/3/bahrain-uprisinginterventionsaudiarabiaemirates.html (accessed on 12 October 2019).

Human Rights Watch. 2015. Yemen: Houthis Send Children into Battle. May 12. Available online: https: //www.hrw.org/news/2015/05/12/yemen-houthis-send-children-battle (accessed on 28 December 2019).

Human Rights Watch. 2017. UAE: Domestic Workers' Rights Bill a Step Forward. Available online: https: //www.hrw.org/news/2017/06/07/uae-domestic-workers-rights-bill-step-forward (accessed on 29 December 2019).

Human Rights Watch. 2018. Yemen Events of 2018. World Report 2019. Available online: https://www.hrw.org/ world-report/2019/country-chapters/yemen (accessed on 14 October 2019).

Ibrahim, Ishak. 2014. Egypt's National Plan to Fight Atheism. The Tahrir Institute for Middle East Policy. August 8. Available online: https://timep.org/commentary/analysis/egypts-national-plan-fight-atheism/ (accessed on 19 November 2019).

International Union for Muslim Scholars. n.d. Available online: http://iumsonline.org/en/ (accessed on 18 November 2019).

Issawi, Charles. 2006. An Economic History of the Middle East and North Africa. London and New York: Routledge. First published 1982.

Keppel, Gilles. 1985. Muslim Extremism in Egypt: The Prophet and Pharaoh. Berkeley and Los Angeles: University of California Press.

Kerr, Simeon. 2013. Fall of Egypt's Mohamed Morsi is Blow to Qatari Leadership. Financial Times. July 3. Available online: https://www.ft.com/content/af5d068a-e3ef-11e2-b35b-00144feabdc0 (accessed on 11 November 2019).

Khamis, Jumana. 2018. UAE to Promote Global Tolerance. Gulf News. November 15. Available online: https: //gulfnews.com/uae/government/uae-to-promote-global-tolerance-1.60380995 (accessed on 3 November 2019). 
Kingdom of Saudi Arabia. n.d. Vision 2030. Available online: https://vision2030.gov.sa/en/themes/3 (accessed on 23 November 2019).

Kourgiotis, Panos. 2014. In the Name of 25 January Revolution: Sisi's Neoliberal 'War on Terror' and the Muslim Brotherhood's Ideological Transformations. Centre for Middle Eastern and Islamic Studies. September 30. Available online: http://www.cemmis.edu.gr/index.php/about-us/team/item/346-in-the-name-of-25-januaryrevolution-sisi-s-neoliberal-war-on-terror-and-the-muslim-brotherhood-s-ideological-transformations (accessed on 13 November 2019).

Kourgiotis, Panos. 2016. Salafism as a tool of Saudi Arabian post-Arab Spring diplomacy. Hemispheres Studies on Cultures and Societies 31: 13-21.

Lacroix, Stephane. 2011. Awakening Islam: The Politics of Religious Dissent in Contemporary Saudi Arabia. Translated by George Holoch. Paris: Presses Universitaires de France.

Leonard, Mark, Catherine Stead, and Conrad Smewing. 2002. Public Diplomacy. London: The Foreign Policy Centre.

Mandaville, Peter, and Shadi Hamid. 2018. Islam as Statecraft: How Governments Use Religion in Foreign Policy. Foreign Policy at Brookings. Available online: https://www.brookings.edu/wp-content/uploads/2018/11/FP_ 20181116_islam_as_statecraft.pdf (accessed on 18 November 2019).

Mansour, al-Moaddel. 2005. Islamic Modernism, Nationalism and Fundamentalism. Chicago and London: Chicago University Press.

Marrakesh Declaration. 2016. Marrakesh Declaration. January 25-27. Available online: http://www. marrakeshdeclaration.org/files/Bismilah-2-ENG.pdf (accessed on 3 November 2019).

MEE, and Agencies. 2015. UAE Spent More Than Half of 2014 Aid Budget on Egypt. Middle East Eye. December 23. Available online: https://www.middleeasteye.net/news/uae-spent-more-half-2014-aid-budget-egypt (accessed on 5 October 2019).

Mielcarek, Romain. 2019. Why Is Europe Still Fueling the War in Yemen? The Nation. October 4. Available online: https://www.thenation.com/article/yemen-europe-weapons/ (accessed on 28 December 2019).

Mohammed Bin Rashid School of Government. n.d. Official Page. Available online: https://www.mbrsg.ae/home/ about-us/introduction.aspx (accessed on 6 November 2019).

Moshashai, Daniel. 2018. National Visions as Instruments of Soft-Power in the Gulf Region; The Case of the UAE and Its 2021 Vision. Master's thesis, Johns Hopkins School of International Advanced Studies, Bologna, Italy, May 17.

Mourad, Mahmud, and Yara Bayoumi. 2015. Special Report: Egypt deploys scholars to teach moderate Islam, but skepticism abounds. Reuters. May 31 . Available online: https://www.reuters.com/article/us-egypt-islam-azhar-special-report/special-report-egypt-deploysscholars-to-teach-moderate-islam-but-skepticism-abounds-idUSKBN0OG07T20150531 (accessed on 19 November 2019).

Muslim Council of Elders. n.d. Available online: http://www.muslim-elders.com/en/page/7/who-we-are (accessed on 18 November 2019).

Noreng, Oystein. 2004. The Predicament of the Gulf Rentier State. In Oil in the Gulf; Obstacles to Democracy and Development. Edited by Daniel Heradstveit and Helge Hveem. Oslo: Ashgate Publishing Limited, pp. 9-38.

Nour, Ayman. 2018. Inqilab 3 Yuliu Bitakhtit Saudi wa Tanfidh Imarati (The 3rd July Coup was Executed by the Emirates). Al-Sharq. August 23. Available online: https://www.al-sharq.com/article/23/08/2018/\%D8\%AF\%D8\%A3\%D9\%8A\%D9\%85\%D9\%86-\%D9\%86\%D9\%88\%D8\%B1-\%D8\%A7\%D9\%86\%D9\%82\%D9\%84\% D8\%A7\%D8\%A8-3-\%D9\%8A\%D9\%88\%D9\%84\%D9\%8A\%D9\%88-\%D8\%A8\%D8\%AA\%D8\%AE\%D8\% B7\%D9\%8A\%D8\%B7-\%D8\%B3\%D8\%B9\%D9\%88\%D8\%AF\%D9\%8A-\%D9\%88\%D8\%AA\%D9\%86\%D9\% 81\%D9\%8A\%D8\%B0-\%D8\%A5\%D9\%85\%D8\%A7\%D8\%B1\%D8\%A7\%D8\%AA\%D9\%8A (accessed on 15 November 2019).

Nuruzzaman, Mohammed. 2015. Qatar and the Arab Spring: Down the foreign policy slope. Contemporary Arab Affairs 8: 226-38. [CrossRef]

Nye, Joseph S. 2005. Soft Power: The Means to Success in World Politics. New York: PublicAffairs.

Nye, Joseph S. 2019. Soft Power and Public Diplomacy Revisited. The Hague Journal of Diplomacy 14: 7-20. [CrossRef] 
Organization for Economic Co-Operation and Development. 1971-2018. UAE Statistics (1971-2018). Available online: https://stats.oecd.org/qwids/\#? $\mathrm{x}=2 \& \mathrm{y}=6 \& \mathrm{f}=3: 51,4: 1,1: 76,5: 3,7: 1 \& \mathrm{q}=3: 51+4: 1+1: 2,25,76+5: 3+7: 1+2$ : $1+6: 1971,1972,1973,1974,1975,1976,1977,1978,1979,1980,1981,1982,1983,1984,1985,1986,1987,1988,1989$, 1990,1991,1992,1993,1994,1995,1996,1997,1998,1999,2000,2001,2002,2003,2004,2005,2006,2007,2008,2009, 2010,2011,2012,2013,2014,2015,2016,2017,2018 (accessed on 26 November 2019).

Otaiba, Yusef. 2016. Why Tolerance has a Place in Islam and the Middle East. CNN. November 16. Available online: https:/edition.cnn.com/2016/11/16/opinions/tolerance-has-a-place-islam-middle-eastal-otaiba/index.html (accessed on 20 October 2019).

Pargeter, Alison. 2010. The Muslim Brotherhood. The Burden of Tradition. London: Saqi Books.

PEACEMS. 2014. Forum for Promoting Peace in Muslim Societies. Available online: https://peacems.com/aboutus/brief/goal/ (accessed on 31 October 2019).

PEACEMS. 2016. Forum for Promoting Peace in Muslim Societies. Available online: https://peacems.com/forums/ forum-2016/ (accessed on 1 November 2019).

Rahman, Fazlur. 1982. Islam and Modernity; Transformation of an Intellectual Tradition. Chicago and London: University of the Chicago Press.

Ramani, Samuel. 2019. Saudi Arabia and the UAE Reboot Their Partnership in Yemen. Carnegie Endowment for International Peace. September 26. Available online: https://carnegieendowment.org/sada/79925 (accessed on 12 October 2019).

Reverend, Thomson, Andy, and Pastor Jeremie Rinne. 2018. The United Arab Emirates Is a Home for All Faiths in the Middle East. Daily Caller. July 26. Available online: https://dailycaller.com/2018/07/26/uae-home-for-allfaiths-in-middle-east/ (accessed on 6 November 2019).

Roberts, David B. 2014. Qatar and the Brotherhood. Survival; Global Politics and Strategy 56: 23-32, Published electronically: July 23. [CrossRef]

Royal Embassy of Saudi Arabia in Cairo. 2012. Doc\#47727, Folder\#1549548. Wikileaks.org/The Saudi Cables. October 4. Available online: https://wikileaks.org/saudi-cables/doc47727.html (accessed on 15 November 2019).

Saleh, Heba, and Camilla Hall. 2012. Morsi Attempts to Ease Saudi Concerns. Financial Times. July 11. Available online: https://www.ft.com/content/cb9f85ac-cb45-11e1-b896-00144feabdc0 (accessed on 26 November 2019).

Samuel-Azran, Tal. 2013. Al-Jazeera, Qatar and New Tactics in State-Sponsored Media Diplomacy. American Behavioral Scientist 59: 1293-311. [CrossRef]

Schwedler, Jillian. 2013. Islamists in Power? Inclusion, Moderation and the Arab Uprisings. Middle East Development Journal 5: 1-18. [CrossRef]

Sirriyeh, Hussein. 1984. US Policy in the Gulf 1968-1977; Aftermath of the British Withdrawal. London: Ithaca Press. Sky News Arabiyya. 2015. Sawab: Markaz Imarati-Amriki li Muajahat Da 'esh (Sawab: An Emirati-US Counter-Extremism Center). July 9. Available online: https://www.skynewsarabia.com/middle-east/758433\%D8\%B5\%D9\%88\%D8\%A7\%D8\%A8-\%D9\%85\%D8\%B1\%D9\%83\%D8\%B2-\%D8\%A7\%D9\%95\%D9\%85\% D8\%A7\%D8\%B1\%D8\%A7\%D8\%AA\%D9\%8A-\%D8\%A7\%D9\%94\%D9\%85\%D9\%8A\%D8\%B1\%D9\%83\% D9\%8A-\%D9\%84\%D9\%85\%D9\%88\%D8\%A7\%D8\%AC\%D9\%87\%D8\%A9-\%D8\%AF\%D8\%A7\%D8\%B9\% D8\%B4 (accessed on 19 November 2019).

Stein, Ewan, and Frederic Volpi. 2015. Islamism and the State after the Arab Uprisings: Between People Power and State Power. Democratization 22: 276-93.

Stora, Benjamin. 2001. Algeria 1830-2000; A Short History. New York: Cornell University Press.

The Islamic Ummah Party. n.d. Al-Mamlakatu Bain Rabi 'Ain, (The Kingdom between Two Springs). Available online: https://islamicommaparty.org/statement/the-kingdom-is-between-two-weeks/ (accessed on 12 November 2019).

The National. 2012. Brotherhood 'Sought 'Islamist State in the UAE'. September 21. Available online: https: //www.thenational.ae/uae/brotherhood-sought-islamist-state-in-uae-1.576627 (accessed on 16 November 2019).

Tran, Mark. 2015. Presence at Paris Rally of Leaders with Poor Free Press Records Is Condemned. The Guardian. January 11. Available online: https://www.theguardian.com/world/2015/jan/11/paris-rally-charlie-hebdofree-press-reports-without-borders (accessed on 17 October 2019). 
UAE Government. n.d. The UAE's Aid to Foreign Countries. Available online: https://www.government.ae/en/ information-and-services/charity-and-humanitarian-work/the-uae-aid-to-foreign-countries (accessed on 14 October 2019).

UAE Ministry of Tolerance. n.d. Strategic Goals. Available online: https://www.tolerance.gov.ae/ar/strategy.aspx\# (accessed on 3 November 2019).

UAE The Cabinet. n.d.a. Anti-Discrimination/Anti-Hatred Law. Available online: https:/www.government.ae/en/ about-the-uae/culture/tolerance/anti-discriminationanti-hatred-law (accessed on 4 November 2019).

UAE The Cabinet. n.d.b. Federal Governments' Strategies and Plans. Available online: https://www.government. ae/en/about-the-uae/strategies-initiatives-and-awards/federal-governments-strategies-and-plans (accessed on 4 November 2019).

UAE The Cabinet. n.d.c. His Highness Sheikh Mohammed bin Rashid al-Maktoum Message to the World: Why Ministers for Happiness and October 2019) UAE The Cabinet. His Highness Sheikh Mohammed bin Rashid al-Maktoum Message to the World: Why Ministers for Happiness, Tolerance, Youth and the Future? Available online: https://uaecabinet.ae/en/details/news/why-ministers-for-happiness-tolerance-youth-and-the-future (accessed on 14 October 2019).

UAE The Cabinet. n.d.d. National Tolerance Program. Available online: https://www.government.ae/aboutthe-uae/strategies-initiatives-and-awards/federal-governments-strategies-and-plans/national-toleranceprogramme (accessed on 3 November 2019).

UAE The Cabinet. n.d.e. UAE Launches 5-Year Foreign Aid Strategy. Available online: https://uaecabinet.ae/en/ details/news/uae-launches-5-year-foreign-aid-strategy (accessed on 14 October 2019).

United Arab Emirates Population Statistics. 2019. Available online: https://www.globalmediainsight.com/blog/ uae-population-statistics/ (accessed on 5 November 2019).

Vassiliev, Alexei. 1998. The History of Saudi Arabia. London: Saqi Books.

Westall, Sylvia. 2019. Inside the UAE's Lobbying Efforts to Lift European Weapons-Export Bans. Reuters. December 12. Available online: https://www.reuters.com/article/us-emirates-security/inside-the-uaeslobbying-efforts-to-lift-european-weapons-export-bans-idUSKBN1YG1L5 (accessed on 28 December 2019).

Young, Karen E. 2013. The Emerging Interventionists of the GCC. Paper No. 2. LSE Middle East Center Paper Series; London: LSE Middle East Center.

(C) 2020 by the author. Licensee MDPI, Basel, Switzerland. This article is an open access article distributed under the terms and conditions of the Creative Commons Attribution (CC BY) license (http://creativecommons.org/licenses/by/4.0/). 
Article

\title{
From 'Soft' to 'Hard' to 'Moderate': Islam in the Dilemmas of Post-2011 Saudi Foreign Policy
}

\author{
Stella Athanasoulia \\ Institut de Recherches et d'Études sur les Mondes Arabes et Musulmans (IREMAM), Aix-Marseille Université, \\ 13100 Aix-en-Provence, France; stella.athanasoulia@etu.univ-amu.fr
}

Received: 8 March 2020; Accepted: 13 April 2020; Published: 22 April 2020

\begin{abstract}
Due to its specific history, Saudi Arabia's domestic and international politics are inextricably linked together. In the shaping and implementation of the kingdom's essentially defensive international behavior, Islam has kept a central position as a legitimizing factor and as a tool of 'soft power' foreign policy. This paper firstly aims to explore the position that religion holds in the Saudi perceptions of stability in the post-2011 era, where safeguarding the status quo remained the priority, while the new administration responded to external pressure by shifting towards a 'hard power' foreign policy with questionable results. Furthermore, the paper explores the links between foreign policy choices and the promotion of a new, modern image for the kingdom whereas the regime has appropriated for itself the notion of 'moderate Islam' in order to restore its international image and attract investments for the 'Vision 2030' reform program. Finally, it proposes a discussion of the position of Islam in the future direction of the country, amidst an increasing authoritarian rule.
\end{abstract}

Keywords: Saudi Arabia; Islam; foreign policy; Arab Spring; Gulf; salafism; Iran; Muslim Brotherhood

\section{Introduction}

Saudi Arabia's international attitude in recent years has been labeled aggressive, reckless or even outright dangerous, in contrast with decades of cautious reserve and status quo-oriented foreign policy. This departure from the traditional mentality of restraint has been described as a shift from "defensive realism" to "offensive realism". According to this approach, "defensive realism stresses moderate, cautious policies in the pursuit of security. Survival is best realized through a mentality of restraint that tends towards small, incremental and non-disruptive actions in security seeking", whereas offensive realists consider that in the quest for survival "there is no such thing as an adequate level of security; states must hoard as much as possible" by maximizing their power at the expense of their rivals and adopting unilateral behavior and regional hegemony to secure their survival (Rich 2019).

Indeed until 2015, the Saudi monarchy demonstrated a cautious, status quo foreign policy in line with its main priorities of domestic stability and external security (Gause 2018). Effectively unable to project hard power, Saudi Arabia displayed a foreign attitude based on diplomacy and balancing through regional alliances, such as the Gulf Cooperation Council (GCC), while delegating its external security, and most importantly the secure flow of its oil production, to the US security umbrella (Nonneman 2006). Domestic stability effectively meant the secure flow of revenues from oil production, upon which the Saudi economy and the unity of the regime depended, itself built upon a patronage system running through all segments of Saudi society, whilst relying on the ulama (religious scholars) for legitimacy. Therefore, the internal stability heavily relied on external security of its borders and the uninterrupted trade through the Gulf.

Saudi Arabia's foreign policy orientation has relied upon two pillars which allowed it considerable freedom of maneuver; financially, its position as an oil giant gave it a leading role within the OPEC and the global oil trade. Spiritually, the custodianship of Islam's holy places gave the monarchy and 
religious authorities the mobilization capacity of over a billion Muslims, while the pact between the royal family and the religious establishment provided the moral grounds of internal legitimization. The Saudi state has relied heavily upon these two elements of soft power, religious ideology and financial largesse (Korany and Moataz 2008), to attain its foreign policy objectives. The accumulation of wealth in the second half of the twentieth century made it possible to project its native religious discourse to other Muslim countries through its $d a^{\prime} w a$ (proselytizing) mission via a number of state and independent religious institutions and organisations such as the Muslim World League (MWL), the Organisation for Islamic Cooperation (OIC) and international offices affiliated with the Ministry of Islamic Affairs, and through the courses offered by the Islamic University of Medina and the Imam Muhammad Ibn Saud Islamic University in Riyadh (Commins 2015).

Furthermore, throughout the 1950s and 1960s the dual pillars of this strategy kept the kingdom from external rival ideologies such as Nasserism and Baathism and positioned it as the defender of the umma (the Muslim community) against the Soviet Union during the Cold War. As new perceived external threats rose in the following decades, Saudi religious diplomacy was deployed as a foreign policy tool in order to face the danger of the Iranian Islamic Revolution, the Islamist opposition expressed by diverse groups affiliated with the Muslim Brotherhood (MB) following the Gulf War in 1991, and jihadism following 9/11 (Mouline 2020). Following the 2001 attacks, and as in previous times of crisis, this tool was further deployed in order to whitewash the image of the regime and to clarify that extremism in fact emanates from distorted interpretations of Islam, namely by the Muslim Brotherhood and violent jihadism. Hence, religion is incorporated in Saudi Arabian foreign policy as a tool of "soft power" in order to serve geopolitical objectives and used as a "space for expressing conventional geopolitical rivalries" (Mandaville and Hamid 2018). This has become particularly evident since 2003, when the Saudi-Iranian rivalry entered a new era of tension.

Regionally, the US invasion of Afghanistan and Iraq left vacuums that the main rival of Saudi Arabia in the region was swift to fill, thus creating a context of sectarian divisions, violence and heightened tension between Iran and Saudi Arabia in what was called the "new Middle East Cold War" (Gause 2014). Iranian expansionism mainly in Iraq, Syria and Lebanon, as well as the added challenge of jihadist attacks on its own soil, was at the core of the Saudi regime's threat perceptions until the outbreak of the Arab Spring in 2011.

The consequent transition processes and civil wars that followed the revolts added new layers of crisis in the region, further challenging Saudi Arabia on multiple levels: on the ideological level, its primacy was contested by the strengthening of the Muslim Brotherhood and political Islam narratives which caused further fragmentation within the Sunni world. The rise of the Islamic State and the territorialization of Salafi jihadism also challenged the Saudi perception of being the Islamic state par excellence. On the geopolitical level, the weakening of the relations with the US under the Obama administration and the nuclear deal reached with Iran in 2015 exacerbated Saudi security dilemmas, thus imposing a rethinking of foreign policy objectives and the means to achieve them.

The new foreign policy dogma and the shift towards an offensive realist attitude materialized under King Salman and especially since the promotion of his son Mohammad Bin-Salman (MBS), emboldened by the arrival of President Trump and his intense anti-Iran rhetoric. However, this strategy quickly produced very mixed results, considerably damaging the regime's international image. Parallel to the demonstrated aggressiveness, the Saudi leadership promotes a renewed "soft power" policy under the banner of "moderate Islam" and the modern "Vision 2030" internal reform program. While these coincide with a recent turn towards diplomacy, they are perceived more as a public relations tool, complementary to the current aggressive tactics, rather than a complete U-turn towards the former behavior pattern, resembling the definition of defensive realism.

Based on academic literature on Saudi Arabian foreign policy and more recent empirical observations, this paper aims to examine the recent developments in Saudi Arabia's international behavior and to observe the role of Islam in current security dilemmas and policy objectives, taking into account the geopolitical factors that weighed on the leadership's threat perceptions pre- and 
post-2011 reconfigurations. Furthermore, it aims to show that under King Salman the foreign policy direction shifted towards an offensive realist attitude in pursuing three main objectives; (1) to gain a hegemonic role in the Gulf region, (2) to contain Iranian expansionism and (3) to contain political Islam as manifested through Muslim Brotherhood-affiliated organizations and their patron states in the Middle East. Finally, it intends to examine the (geo)political and ideological motivations behind the notion of 'moderate Islam' promoted by the Saudi leadership. Acknowledging that this is an ongoing process whose results remain to be seen, this paper attempts a discussion on the nature of Islam to which Saudi Arabia wishes to adhere, at a time when internal developments point towards a merge of Salafism and nationalism, amidst an intensifying authoritarian rule (Blin 2016).

\section{Saudi Arabia Post-2011: Responding to the Challenges through 'Hard Power' and 'Moderation'}

\subsection{Arab Spring Reconfigurations}

In order to better gauge the impact of the Arab Spring on Saudi perceptions of threat and the quest for regime survival within a complicated geopolitical context, it is useful to examine it through the framework of the "New Middle East Cold War", as analysed by Gause (2014).

The current geopolitical context in the Middle East bears striking resemblances to what was called the Arab Cold War in the 1950s-1960s when the domestic struggles of weak regional states constituted the theater of confrontation, in which the main actors exerted their influence through local state and non-state actors. While the main camps were not always united, a measure of success was also found in the ability of actors to juggle different alliances, thus crossing the main lines of conflict. In the current Middle East Cold War, the leading roles are played by Iran and Saudi Arabia in a balance of power game that witnesses no military confrontation, but plays out in various local and regional theaters.

When the uprisings began, Saudi Arabia was already alarmed by Iran's expansionism, dating back to the US invasions of Afghanistan and Iraq and the subsequent power vacuums created, which the Iranian leadership swiftly filled. During the 2000s the Saudi leadership retained its reserved and non-confrontational way and worked behind the scenes in order to find a regional modus vivendi with the Iranians, thus refraining from any openly hostile relations. Sectarian tensions were a major element in the conflict and were played by both sides, however in a way that served their geopolitical objectives within the renewed "cold war" context, which goes beyond a simplistic sectarian line of "Sunni versus Shi'a" divide. For example, during the Iraqi transition period, Saudi Arabia strongly supported Iyad Allawi, a secular politician but Shi'a by birth and whose coalition was cross-sectarian and thus hardly a Sunni bloc. Hence a multitude of variables add to the equation, such as the dynamics of domestic conflicts, transnational affinities and regional state ambitions, feeding into the complicated geopolitical context, but not driving it on their own (Gause 2014).

In the immediate outbreak of the Arab Spring, the various reactions of Sunni powers in the region caused realignments that went on to provoke serious divisions among them and further amplify the Saudi security dilemmas. Saudi Arabia immediately took the lead of the counter-revolutionary bloc along with the United Arab Emirates (UAE) — and later post-Morsi Egypt—-that saw the uprisings as an existential threat to their internal stability and survival and sought to "maintain the status quo at all costs" (Gerges 2016). The prospect of a democratic Islamist type of government which became clear after the parliamentary election and constituent assembly elections of 2011 in Egypt and Tunisia respectively, was deeply unsettling for the kingdom. In Egypt, the Muslim Brotherhood's Freedom and Justice Party and the Salafi Nour Party took nearly $70 \%$ of the seats between them. Furthermore, the Muslim Brotherhood candidate Muhammad Morsi won a very close race against Mubarak's last prime minister in the 2012 presidential election. Although in Tunisia the Muslim Brotherhood affiliate did not fare so well, the trend was clear and the Saudi leadership saw in it the danger of a regime that could "credibly contest its role as leader of the Sunni Muslim world, and even present an alternative form of Sunni Islamist politics to the Saudi monarchical model" (Gause 2014). 
The deep mistrust towards the Brotherhood caused further rifts among Sunni powers. On the one hand Saudi Arabia and the UAE, sharing the same aversion for the Brotherhood, deployed enormous funds towards containing the perceived danger of political Islam. Both countries generously funded General Abd-al Fattah al-Sisi's takeover following the coup that overthrew Morsi in 2013, as well as the Libyan General Khalifa Haftar in his operation against the Tripoli-based Government of National Accord (GNA). In Tunisia, the Saudis supported a coalition of secularists and old-regime officials during the elections. On the other hand, the pro-revolutionary bloc consisted of those who actively backed the revolutionary movements throughout the region: Turkey and Qatar rallied behind the revolts and supported Mohammad Morsi in Egypt, MB-linked parties in Libya and the Tunisian Ennahda. Following Morsi's overthrow, Qatar provided refuge to Brotherhood leaders, deepening the polarization with Saudi Arabia and culminating in the kingdom designating the MB a terrorist organisation in 2014, thus equating it with Al-Qaeda and the Islamic State. The spat also led to a brief break of diplomatic ties between some GCC members and Qatar, adding another axis of confrontation to an already complicated context that has locked the pro- and counter-revolutionary blocs in a conflict over what the proper political role of Islam should be in the Sunni world (Gause 2014).

Saudi Arabia thus found its predominant ideological position within the Sunni world challenged by those forces that emerged during the transitions and the civil wars that ensued; mainly those represented by the Muslim Brotherhood, but also by the reconfigurations within the Salafi trend as these were expressed in its three main currents: the violent Salafi jihadi current, the quietist and largely apolitical current and the activist Salafi current which was clearly strengthened in the aftermath of the Arab Spring. Among them, the most visible challenge emanated from the jihadi Salafi movement, mainly through the Islamic State's re-emergence in Iraq, Syria and beyond, in its territorialized version. Through its adoption of violent practices and aspiration to control a certain space and a certain population, the Islamic State not only challenged Saudi Arabia's legitimacy as the Islamic state par excellence, it also targeted the kingdom on its own territory in the same manner as Al-Qaeda did since 2003 (Bonnefoy 2018).

The quietist Salafi trend (salafiyya ilmiyya or da'wiyya), the one most closely associated with the Saudi $d a^{\prime} w a$, was caught on the opposite side of the popular protests due to its prescribed strict obedience to the Muslim ruler. Their support to status quo regimes saved the quietist Salafis from repression, while during the revolts they were rallied to engage in favor of these regimes, as for example in their support for Muammar Qadhafi at the beginning of the Libyan uprising. By merit of their apolitical stance quietists are considered moderate, although in terms of creed their views are rather radical. Quietist networks in various countries have developed strong links with a number of Saudi ulama who have a transnational following, such as Rabi al-Madkhali (Bonnefoy 2018). The failure of the political experiment in Egypt and the rapid deterioration of the security and social situation in other countries allowed the quietist branch to maintain relevance in the eyes of militants. In the Libyan case, they became influential through their alliance with General Khalifa Haftar, in his fighting against the GNA with generous support from Egypt, the UAE and Saudi Arabia. Salafi fighters and militias constitute an important force used by Haftar, especially since his operation to retake the capital, Tripoli (International Crisis Group 2019).

The emerging politicization of activist Salafism (salafiyya harakiyya) is perhaps the most important aspect of the reconfigurations that took place in the post-Arab Spring societies. The emergence of the al-Nur party in Egypt and other Salafi parties, such as the al-Rashad in Yemen, the Ansar al-Sharia movement in Tunisia or the al-Fatih mosque in Bahrain signaled a passage to politics, in a clear break with their apolitical past (Bonnefoy 2018). Activist Salafism emerged as a rejection of quietism and of the Saudi monarchy in the 1990s through the Sahwa movement, a blend of Muslim Brotherhood and Salafi thinking that has expressed the most serious Islamist opposition to the regime since the Gulf war in 1990. Although engaged in the public sphere in various countries since their emergence, they never presented a serious alternative to nationalist or MB-linked political forces who were already engaged in the democratic process. As their politicization intensified post-2011 in Egypt, Tunisia 
and Yemen, but remained less dynamic in Saudi Arabia, it has become clear that Salafism is a truly transnational phenomenon that adapts to both regional and local circumstances. This is evident in the Yemeni case for example, where local Salafi movements emerged as both pro- and anti-Saudi in the 1980s, as in the case of Muqbil al-Wadi'i who was critical of the policies and the legitimacy of the Al-Saud. Later on they repositioned themselves towards closer ties with Saudi Salafi networks, whilst demonstrating different levels of support for the Saudi military intervention in Yemen after 2015. As Laurent Bonnefoy notes: "[... ] the capacity of Saudi Arabia to control outcomes and exercise 'soft power' through Salafism is far from certain. [...] such a development highlights the increasingly transnational character of Salafism and shows the extent to which Saudi Arabia, while playing a special role, is not the sole driver of the development of Salafism across the Muslim world" (2013).

With regards to the Iranian expansionist threat, the Arab Spring was another cause of serious concern to the Saudi regime, which saw an increasing Iranian role in the civil wars in Syria, Yemen and in the Bahrain revolt, and thus a serious threat in the Arabian Peninsula. The Syrian uprising against Bashar al-Assad was the only revolt where Saudi Arabia in which took the side of the opposition, albeit not driven by any anti-Alawite sentiment, but rather seeing it as the only opportunity to roll back Tehran's influence. Although slower than Turkey and Qatar in supporting the opposition forces, Saudi Arabia's initial support for the more secular Free Syrian Army later shifted towards Islamist and more specifically Salafi groups. Furthermore in Bahrain, the Saudi-led suppression of the revolt took place in the context of the GCC and was the first time in decades that Saudi troops were sent into the field, in order to save a mini-patron dynasty from demands for legitimate rule rather than a purely sectarian, Shi'a contestation of its power. In Yemen, the Saudis were able to reaffirm their central position in the country's politics by negotiating Ali Abdallah Salih's resignation, but remained increasingly alarmed at the Huthi progressive gains, which they saw as an Iranian encroachment effort. Although the Iranian influence over the Huthis is widely overestimated, the Saudi leadership saw in the movement's intense anti-American and anti-Israel discourse further proof of the Iranian connection (Gause 2014).

Apart from the perceived Iranian role in the Arab uprisings, the Saudi security dilemmas were also exacerbated by the clear advance in nuclear negotiations between Iran and Western powers, as well as the US reluctance in taking up a leading role during the Arab Spring. The P5+1 negotiations over Iran's nuclear program were stepped up following the election of moderate President Hassan Rouhani, leading to the November 2013 interim agreement; the Joint Plan of Action agreed in 2014 was set to ease the sanctions against Iran while setting a timeline for the agreement implementation in early 2015. Largely seen as a reward towards the Iranians, despite Barack Obama's visit to Riyadh to ease the Saudi displeasure, the nuclear deal was perceived as another setback in the Saudi effort to roll back Iran's growing gains in the region (Blin 2016). The Obama administration supported the transitions instead of backing old allies in Egypt and elsewhere, thus sparking a fear among Gulf monarchies that they could be next, in the case of internal destabilization. Additionally, in Syria and Iraq, US interests went beyond the narrow balance of power game between Iran and Saudi Arabia, thus pointing to a perceived "inconsistent" and "passive" policy signaling an imminent retreat from the region (Gause 2014).

Domestically, the Arab Spring presented another potential challenge, as it gave new impetus to Sahwa-linked and liberal Islamists, albeit not very visible. The Sahwa embraced the Egyptian and Tunisian revolutions, and the overthrow of President Morsi marked a point of renewed criticism against the Saudi regime's role in General Sisi's coup. Protests took the form of street demonstrations, sit-ins at symbolic places, prisons, and governorates; and petitions were widely disseminated through social media (Lacroix 2014). The Saudi Grand Mufti Abd al-Aziz Ibn Abdullah Al al-Sheikh was quick to denounce the uprisings as "planned and organised by the enemies of the umma" (Murphy 2011), while the government reacted using a carrot and stick strategy. In spring 2011, King Abdullah announced economic stimulus amounting to around $\$ 130$ billion and civil servants (roughly two-thirds of the workforce) received a $15 \%$ raise in wages and a bonus of an extra two months' pay. However, it also cracked down hard against protesters and brought about widespread arrests, especially from 2014 
onwards, as the MB designation as a terrorist organisation provided the regime with the ability to label and arrest any opposition voice under this pretext (Hoffman 2019).

Within the geopolitical landscape that emerged following the Arab Spring, a series of factors served as a reminder to the Saudi leadership that rethinking and re-defining its foreign policy was an imperative should it wish to secure the stability of the country and the survival of the regime. On top of the geopolitical and ideological factors that weighed in the Saudi perceptions of threat and falling oil prices, the taking of Sanaa by Huthi rebels at the end of 2014 served as a wake-up call that Iranian expansion had reached the southern underbelly of the Arabian peninsula.

\subsection{The Limits of an Offensive Foreign Policy under a New Leadership}

Against the backdrop of heightened threats and challenges to Saudi security, the passing of King Abdallah in January 2015 and the ascendance of King Salman clearly mark an abrupt shift in the kingdom's foreign policy. While the behavior turned aggressive rather quickly, the three main objectives of this policy remained relatively unchanged; (1) contain the Iranian danger regionally, (2) contain the gains of political Islam and the Muslim Brotherhood in particular and (3) gain a hegemonic regional role, shielding the kingdom from any external threat that could have a destabilizing effect internally (Dazi-Héni 2018a). The new strategy - dubbed by some observers as "Salman's Doctrine" (Middle East Monitor 2015)- is characterized by more centralized decision-making and relies on two main elements: (a) high defense spending and (b) military alliance building. In light of the above definition, the new concept thus bears the characteristics of an offensive realist turn in foreign policy implementation (Nuruzzaman 2019).

With regards to foreign policy decision making, the new concept translated into the swift promotion of Mohammed Bin Salman to the position of defense minister and deputy crown prince, then to crown prince, atop a long list of other portfolios. Under MBS's leadership and with the mentoring of the Crown Prince of Abu Dhabi, Mohammad Bin Zayed, the security sector was set to undergo considerable modernization, in order to provide flexibility and operational capacity to a force that was until then neglected. In 2018, Saudi Arabia was the third biggest military spender globally and the first in the region with $\$ 67.6$ billion in expenditure which amounts to $8.8 \%$ of its GDP (SIPRI 2019). However, what took place instead of a major overhaul was the creation of a Joint Operational Command and two new bodies handling procurements and reporting directly to MBS (Al Sayegh 2017). In June and July 2017, all counterterrorism and domestic intelligence agencies were brought under a single new body, the Presidency of State Security (PSS) (Sayigh 2018), while the National Guard (SANG) came under the command of an unexperienced yet loyal prince. Miteb bin-Abdallah, son of the late king and commander of the SANG, was ousted in November 2017 (Partrick 2018). Similarly, the ousting of the former Crown Prince and Interior Minister Mohammad Bin-Nayef, who had long experience in internal security and intelligence issues and was in close counter-terrorism cooperation with the US, was seen as the eviction of a potential rival from a crucial post (Benjamin 2018). The creation of new bodies under MBS's direct supervision further signaled the distancing from the traditional collegiality and consensus which, in the past, secured family unity by dividing the top brass posts among senior royals with long experience in state and security affairs, with the latter being a sign that "personal loyalty, not experience or expertise, is still the crucial determinant of getting ahead" (Wittes and Riedel 2018).

On top of investing in the armed forces, the Saudi government embarked on a course of creating alliances in order to support its anti-Iran objectives. First, it formed a nine-nation Arab coalition in April 2015 to fight back the Shi'a Houthi rebels that it claimed Iran was supporting (Kirkpatrick 2015). Later on, in December 2015, MBS announced the formation of a broader alliance-the 34-nation Islamic Military Counter Terrorism Coalition. Although its vague proclaimed scope was to fight regional "extremist" forces, mainly IS and Al-Qaeda, it is hard to miss that it was created as a Saudi-led Sunni alliance, hardly obscuring its main goal of pushing Iran into retreat from Iraq and Syria (BBC News 2015). However, participation in these alliances was motivated more by the Saudi financial 
largesse rather than spontaneous commitment to the anti-Iran cause. While some countries outright refused to participate, such as Pakistan and Oman, others only joined after securing guarantees in the form of oil concessions or financial aid. Sudan received \$2.2 billion in aid from Saudi Arabia and Qatar, while Egypt received a Saudi $\$ 8$ billion investment commitment (Nuruzzaman 2019).

The new doctrine materialized quickly after MBS took over the defense ministry with the beginning of the Yemen campaign. The stated purpose of the Saudi intervention in Yemen was to stop the extremist Huthis from taking over the country, and to send a strong a message to Iran that its advance would not be tolerated in the south of the Arabian Peninsula. The campaign also aimed at proving that Saudi Arabia was capable of mobilizing a strong Arab coalition and that the Gulf countries were ready to fight a long war-with the necessary backing from the US, UK and France. For the UAE, Saudi's main Gulf ally in the campaign, Yemen was equally important in order to demonstrate the capacity to form a genuine national army and affirm their own position in Gulf affairs (Blin 2016).

Almost five years after the beginning of the Yemen intervention, the Saudi policy seems stuck in a quagmire with no exit strategy, but with incalculable humanitarian, financial, strategic and reputational costs for the Saudis and no realistic advance of the declared objectives (Gordon 2018). According to Brookings, the monthly cost of operations is over $\$ 5$ billion (Riedel 2017a), risking to lead the Saudi economy into recession, while by mid-2018 more than 1000 Saudi troops had perished (Al-Jazeera 2018). In order to continue the campaign, Saudi Arabia relied on foreign support to resupply in weaponry and mercenary forces, which exposed the flaws in its operational capacity. As the humanitarian cost of the war drew intense media attention, international arms suppliers, such as Germany, became more reluctant or even stopped providing weapons to Saudi Arabia (Riedel 2017b). On the ground, Saudi Arabia's tactic of rallying different parts of the Sunni camp had a boomerang effect as it intensified divisions and animosity among them and further benefited the Huthi advances. It also exposed the limits within the alliance, as the UAE and Saudi Arabia pursued divergent strategic interests and supported different local allies until the UAE announced a drawdown in July 2019 (Ramani 2019). Far from deterring Iran, the campaign concentrated on a theater where its presence and interests were at least initially- more marginal than those of Iraq and Syria, and the costs much smaller. The Saudi attempt to counter Iran's influence in this theater intensified following the Russian intervention in Syria which tipped the balance in favor of Bashar al-Assad. Unable to considerably affect the developments inside Syria, the Saudis provided military support to armed opposition groups and political support to the opposition through the Riyadh summit ahead of the UN process. They also stepped up the confrontational tone through the execution of Shi'a Sheikh Nimr-al-Nimr, causing a break of the diplomatic ties between Riyadh and Tehran. Furthermore, to avoid arms ending up in the hands of Hezbollah and by extension, into the Syrian war, Saudi Arabia suspended $\$ 1$ billion arms delivery to Lebanon in February 2016 and led the GCC to designate Hezbollah a terrorist organisation (Blin 2016).

The offensive Saudi policy was further emboldened following the arrival of the Trump administration. In his first foreign trip as US President, Donald Trump was received during a lavish reception in Riyadh in the presence of numerous Arab leaders, at which he denounced extremism and intolerance and signed an equally extravagant deal of $\$ 110$ billion-worth of defense procurements (White House 2017). Trump's bellicose discourse against Iran as the world's foremost sponsor of terrorism and his commitment to tear up the 2015 nuclear deal fell wholly in line with the Saudi thinking, leading observers to "speculation that the Saudis and Israelis may concoct a Palestinian 'peace' agreement, under US auspices, on the way to forming a united front against Iran" (Tisdall 2017). Just days after the Riyad Summit, Saudi Arabia translated this perceived "green light" into the naval and air blockade of Qatar, a direct consequence of the animosity towards the Muslim Brotherhood following the 2011 uprisings, causing an unprecedented rift in the GCC. Friction between the Al-Saud and the Al-Thani families is old, but the current spat, which began back in 2014, led the UAE, Saudi Arabia, Bahrain and Egypt to recall their ambassadors from Doha accusing Qatar of "supporting terrorism" and of actions aiming at "destabilizing the region in accordance with the Iranian tactics in the Gulf and beyond" (Saudi Press Agency 2017). In this instance, Qatar was presented with an 
ultimatum and a list of 13 conditions with which to comply, including shutting down Al-Jazeera and a Turkish military base, essentially demanding that Qatar gave away its sovereignty. This was preceded by a fierce Saudi-UAE media war against Sheikh Tamim in Doha, by mobilizing hacking and fake news (Cafiero 2017), to which the Emir replied by deploying a sophisticated public relations strategy internationally, in order to counter the effects of the blockade and secure financial stability, provisions, and the uninterrupted connection of the emirate to the outside world throughout the crisis (Dazi-Héni 2018b). Riyadh sought to push Qatar to the breaking point through the blockade, while attempting to internally destabilize the al-Thani by backing a renegade member of the family as a potential successor of the emir (The National 2017) and to de-legitimize Qatar's Wahhabi past using a demand from 200 descendants of the Abd-al Wahhab family to rename the Doha mosque named after Ibn Abd-al Wahhab, "for it does not carry its true Salafi path" (Reuters 2017). The 2017 rift has resulted in a bizarre standoff, as the Saudi strategy backfired, incapable of convincing the international community and lacking an alternative plan, while Qatar survived the blockade by cultivating stronger diplomatic, military, and commercial ties with Turkey and Iran (Nakhleh 2017).

The brief detention and forced resignation of Lebanese Prime Minister Saad Hariri was seen as another "aggressive, zero-sum and revisionist stance which aimed to forcibly alter the political character of a foreign power" (Rich 2019). The reasoning behind this move was continuing Saudi displeasure with Hariri's limited moves in curbing Hezbollah's influence in Lebanon. While failing to convince the international community, the Saudi move backfired again as it resulted in renewed international support for Hariri and increased his popularity across the sectarian spectrum at home (Daher 2018). To add to these embarrassing strategic miscalculations, the attacks on two major Aramco oil installations in September 2019 halted almost half of the Saudi oil production, or 5\% of global production, and fueled criticism towards MBS over his capacity as defense minister to shield the country from terrorism. Although these attacks were later claimed by the Huthis, MBS has insisted that Iran was behind the attacks and called for strong and firm deterrence, yet adding that he would prefer a "peaceful solution" (Reuters 2019).

Hence, the limits of this strategy became clear during the first years of its implementation, through a series of military and diplomatic failures. Even if it was conceived as a proper "doctrine" in imitation of the US concept, it was based more on the expectation of a swift "victory" on various regional fronts that would give Saudi Arabia a preeminent regional role and less a long-term strategic plan to provide external security and regime stability. Yet, despite the aggressiveness in international behavior, largely blamed on the hotheaded and unexperienced character of the crown prince and his entourage, observers also argue that the need to demonstrate success in his domestic priorities would have a constraining effect on his foreign policy (Saab 2018). Indeed, recent diplomatic moves point towards a more pragmatic direction instead of excessive belligerence.

In late 2019, some discreet steps were made towards ending the feud with Qatar (Strobel 2019), with the Qatari foreign minister participating in the Riyadh Summit and the successful organisation of the Gulf Cup in Doha (Henderson 2019). Despite some reasonable optimism, ending the Gulf rift will be a longer, 'incremental process' of serious engagement and dialogue (AFP 2019). Signs of good will from Riyadh underline an attempt to mend MBS's image internationally rather than a genuine desire for a solution, which seems more in line with the UAE's harder stance on the issue (MEMO 2019). Similarly, in Yemen the Saudi leadership has moved towards talks with the Huthis in an effort to de-escalate the conflict, in a clear sign of recalculating the risks undertaken following the oil refinery attacks. According to Rob Malley, 'the sudden willingness to pursue diplomacy in Qatar and Yemen, reflects a Saudi desire to solidify its regional posture at a time of uncertainty and vulnerability' (Walsh and Hubbard 2019). Furthermore, Saudi Arabia reacted cautiously to the US elimination of Iranian general Qassem Soleimani, leader of the IRGC's Quds military force and architect of much of the Iranian strategy in Iraq and Syria, despite the Saudi press hailing the end of a "decades-long dark Iranian shadow over the region" (SPA 2020). The killing may impact the kingdom directly by way of 
retaliation in the form of Huthi attacks on its soil, as well as in its eastern provinces, where Iran has the capacity to mobilize Shi'a organizations hostile to the regime (Farouk 2020).

Thus, it can be argued that, at this time of vulnerability and regional volatility, a more cautious and less belligerent posture is preferred so as to avoid any accident that could lead to direct confrontation and regime instability. Such a scenario would add to an already negative image and have unimaginable domestic costs at a time when external stability and a solid regional role are sought in order secure the prince's undisrupted access to the throne.

\subsection{Promoting a "Moderate" Islam: Realist $u$-Turn or PR Strategy?}

Parallel to the new "hard power" dogma, a "soft power" policy was also put forward in order to appeal to Western governments, business and religious circles and to showcase an image of tolerance, modernity, and conscious social reforms. An intense discourse over "moderate Islam" and a series of high-profile intra-faith and intra-Muslim meetings were coupled with the promotion of 'Vision 2030', the Crown Prince's ambitious plan for reforming all aspects of the economy and modernizing society. 'Vision 2030' mainly aims at moving Saudi Arabia away from its oil revenue dependence, reforming the state bureaucracy and strengthening the private sector, while incorporating modern tools of soft power, such as green energy, tourism and entertainment. Since becoming crown prince in 2017, MBS undertook a series of foreign trips to promote his reformative agenda -not the first comprehensive modernization program announced by the leadership- and thus to establish his royal credentials and secure his future while his father is still alive.

In the context of promoting Vision 2030 abroad, the crown prince has taken up a new religious diplomacy, stating that he wishes to return Sau di Arabia to "moderate Islam" while also arguing that in the past decades the country has steered down a problematic path and that it is time to 'get rid of it' (Chulov 2017). He has stated that "[w]e only want to go back to what we were: a moderate Islam that is open to the world, open to all religions". Yet, he has also added that the young Saudi generation that he represents "will not waste 30 years of our lives in dealing with extremist ideas. We will destroy them today" (Batrawi 2017). Furthermore, 'Vision 2030' describes "a tolerant country with Islam as its constitution and moderation as its method"; however, elaborating on his perception of moderation has raised more questions than answers. First of all, the term "moderate" as opposed to "extremist" becomes problematic as it is used to compare moderation not only to Iran's revolutionary ideology and Salafi jihadism, but to the Muslim Brotherhood as well, since Saudi Arabia considers them both terrorist with no further distinction. However, the Brotherhood's rejection of violence as a means to domestic political change and its participation in pluralist electoral processes sets the organization within the realm of moderation, as examined by recent scholarship on political Islam. Among various approaches that go beyond the purpose of this paper, the inclusion-moderation hypothesis posits that "political groups and individuals may become more moderate as a result of their inclusion in pluralist political processes" (Schwedler 2011), thus rendering MBS's "moderate" argument somewhat contradictory. To the contrary, it helps apprehend the Saudi aversion to the organization as a potential competitor in the realm of Islamist politics.

A second point that merits attention is the term "return" and what it refers to. In MBS's vision, "return" alludes to the country pre-1979 and Iran's revolution (Hellyer 2018a), during the reign of King Faysal, a reformer who tried to open up the country and limit the role of the religious establishment. Yet as the late Jamal Khashoggi has suggested, the 1979 narrative is rather weak as Saudi Arabia "was never moderate" and there is no concrete dividing "before-and-after" line in these events (POMED 2018). Related to this is also the contradiction in the notion of "moderation as its method", as the Hanbali school of jurisdiction followed in Saudi Arabia is in its essence the most strict and exclusionist of the four schools of interpretation of Islam's holy texts (Al-Rasheed 2017).

In this context, since 2016, a series of initiatives and changes within the Muslim World League (WML) have pointed to the direction of this renewed religious diplomacy. The MWL Secretary General, Abdallah Al-Turki, an influential and conservative member of the Council of the Senior Ulama, was 
relieved of his duties after sixteen years of service and replaced by a more moderate and more docile cleric, Muhammad Ibn Abd Al-Karim Al-Issa. His mandate has been clear since taking up his position; aiming to convince international partners of the moderate turn of the country's religious credentials, he set out on foreign trips, meetings with religious dignitaries and intellectuals, and intra- and interreligious conferences. Al-Issa advocates a reconciliation of the religious and the national identity of Muslims worldwide, while insisting on the fact that they must respect the laws of their respective countries, whatever their origin. Furthermore, he defends equality among people and respect and tolerance for different cultures and denounces terrorism at every opportunity, while tempting a redefinition of jihad through its "defensive nature", thus maintaining that attacking civilians is overall forbidden, even in Israel (Mouline 2020). The renewed discourse is complemented by high-profile bilateral meetings and events of a clear symbolic nature. Al-Issa has met and signed cooperation agreements with Pope Francis and members of the Pontifical Council (Al-Sharq Al-Awsat 2018), with Patriarch Kyrill of Russia (Arab News 2019), while Christian dignitaries have been received in Riyadh on many occasions. Most notably, he has officially recognized and denounced the abominable crime of the Holocaust, visited the Holocaust museum in Washington in 2018, and participated in commemorations in Auschwitz in early 2020 (Al-Issa 2019). Furthermore, regional and international summits have been organized in recent months and a number of declarations issued, in which Muslim leaders asserted their and their governments' commitment to religious tolerance. Whilst in previous years these summits were organized in various Muslim countries, the back-to-back organisation of the GCC, OIC, and Arab League Summits in Mecca in 2019 is seen as an attempt to reaffirm Saudi authority in Muslim affairs, as well as a "religious outbidding" of competing co-religionists (Sheline 2019). The geopolitical timing of the summitry is telling, as Saudi Arabia was under intense pressure from the Huthis in Yemen, while the GCC rift remained largely unresolved. However, as Qatar was invited to the summits, presenting an image of unity was clearly intended vis-à-vis Iran (Riedel 2019).

Vision 2030 and international Muslim and business summitry thus serve a double strategy: Regionally, positioning Saudi Arabia as the champion of "moderate Islam" would exclude the "extremists" -namely Iran, the Muslim Brotherhood, and their affiliates- from challenging its hegemonic role and its interests in the Gulf and Middle East region. To further strengthen the anti-Iran front led by the US, this "religiously tolerant" diplomacy was framed as King's Salman desire to consult with his Muslim allies in response to aggression from Iran; most importantly, the new "moderation" adds legitimacy to the rapprochement with the state of Israel (Sheline 2019). Internationally, this strategy promotes a modern and tolerant image to potential Silicon Valley mega-investors, who would finance the futuristic, green energy, robot-run NEOM city at the border with Jordan and Egypt (Tonet and Nasi 2020) and who would be more willing to turn a blind eye to alarming signs of domestic authoritarianism and regional brinkmanship, or, as it has been put in the Jamal Khashoggi case: "the fashioning of an exculpatory fig leaf for an atrocity" (Benjamin 2018).

These observations raise the question of the Saudi perceptions on how Islam should relate to the state as it moves towards a new era of modernity, as Mandeville and Hamid recall (Mandaville and Hamid 2018). In other words, it is worth examining whether Vision 2030 frames the path from a religiously defined state to a politically defined one (Devji 2018). Interestingly, 'Vision 2030' envisages the "Kingdom's leading role and ambitions at the heart of the Arab and Islamic worlds" by "strengthening the sense of national belonging", all this within the context of the chapter on National Character Enrichment (Saudi Vision 2017a). Additionally, the Hajj and Omrah Program aims to open up the Hajj by improving services in Mecca and Medina and to boost its tourism industry by promoting "world-class cultural sites" along with recent extensive tourism campaigns (Saudi Vision 2017b). Hence 'Vision 2030' also aims to boost a Saudi national sentiment, whilst expanding the kingdom's "human and social legacy" and "realizing the message of Islam" in its Salafist purity and liberated -in the eyes of MBS- from the dangerous course it has taken after 1979. Louis Blin maintains that the new leadership is outlining a synthesis of nationalism and Salafism as a foundation of a "salafised patriotism", in accordance with modernity and in the service of blocking Iranian 
expansionism (Blin 2016). In a more global approach, Mandaville and Hamid also pay attention to the way religious soft power is used by certain states within a context of moving towards a post-liberal or post-Western world order and "how other kinds of ideas and narratives are gaining traction not just within states but in how they conduct themselves abroad. That is not to say that these ideas will necessarily be antithetical to the liberal international order, but rather that it may be increasingly possible - and useful—for countries to put a culturally specific spin on liberal economics and to parse their security interests through religion" (Mandaville and Hamid 2018).

In this light, the moderate Islam that MBS promotes would be one that is more amenable to the renewed perceptions of the Saudi economic model and would voice no opposition to those reforms that seem too Western-like and risk alienating the society from its conservative norms. Interestingly and ironically enough, the first steps MBS has taken with regards to his vision of moderate Islam resemble a "variable" of Wahhabi Islam found in the only other state in the world that follows this doctrine: Qatar. The emirate has managed to maintain its Wahhabi character and keep its decision-making independent from the religious establishment, whilst demonstrating a certain openness towards non-Wahhabi Muslims and non-Muslims overall. As James Dorsey notes, "MBS may be discreetly looking towards Qatar's direction in dealing with religion, even though he wouldn't admit it" (2018). However, upending the deeply-rooted relationship with the religious establishment could prove less straight-forward than hoped, whereas moving the country away from its endemic corruption, patronage system, and tribalism may stumble upon opposing interests within the business and royal elite (Takeyh 2017). In his attempt to simultaneously deal with all aspects of potential opposition and clear his way to the throne, MBS has demonstrated a level of authoritarianism that is considered excessive even by Saudi standards. The massive crackdown on activists, moderate intellectuals, and human rights activists points to further contradictions with regards to his professed modernization and moderation plans.

The Council of Senior Ulama, the highest religious authority in Saudi Arabia, remained largely unscathed during the sweeping wave of arrests in September 2017, even with respect to hardline clerics who have expressed extreme postures in the past and have openly opposed the reforms. Although the Grand Mufti Abdulaziz Al al-Sheikh has openly denounced reforms such as the creation of the General Authority for Entertainment, the re-opening of cinemas, and various events as a "depravity" (Ottaway 2018), the core of the official religious establishment has rallied behind MBS's policy choices, by reversing its own fatwa on women driving and by issuing one condemning Qatar for its links to the Muslim Brotherhood, thus legitimizing the blockade. By refraining from censuring even the most controversial clerics within the official establishment, as long as it provides religious justification for his policies, MBS is 'underlining the inequality of the relationship but still far from breaking it' (Ulrichsen and Sheline 2019). A variety of tactics has been used in limiting the outreach of ultraconservative clerics, mainly through blocking social media accounts and tv-appearances, bringing the issuing of fatwas under government control and reminding the religious principle of showing allegiance to the king. As David Ottaway notes, given the extent of the repression, it is hard to assess whether the unease of ultraconservative clerics could translate into outright rebellion in the near future or if they will carry on adapting to yet more change (Ottaway 2018).

The picture is different when it comes to independent clerics and intellectuals, especially within the context of the Sahwa movement. Some clerics have distanced themselves from the Sahwa and have demonstrated an overt support for the crown prince, such as popular figures Aidh al-Qarni and Mohammed al-Arifi; this "repentance", their regional critics argue, validates the regime's appropriation of "moderate Islam" and legitimizes the crackdown on any sign of opposition (Raihan 2019). On the other hand, moderate figures who have voiced opposition to the reforms or who have failed to rally behind MBS's policy choices, namely the blockade against Qatar, were persecuted during the 2017 repression including many Sahwa members (Farouk 2018). The most telling example is moderate cleric Salman al-Awda, an influential figure of transnational Salafism with over 21 million followers on Twitter, well beyond the kingdom. With a long history of cooptation and imprisonment by the Saudi 
regime since the 90s, Al-Awda was arrested again in 2017 and has stood trial on numerous charges, yet a decision on the death penalty is still pending, which shows how deeply political the issue is (Freer 2019). Awda's execution would bear a rather important cost. Apart from causing the ire of his supporters and human rights organizations (Amnesty International 2019), the marginalization of the true "moderate" voices would create a vacuum in the uncontrolled sphere of the Internet and social media that more activist Islamist - or jihadi - voices would see as an easy field to fill. Furthermore, an execution would have a negative impact on the image of tolerance that the recent international summitry has attempted to promote (Riedel 2019).

In recent months it has become evident that the main priority of the government is to restore its image and attract investors through the upcoming Saudi Aramco's Initial Public Offering (IPO) and the hosting of the G20 summit at the end of 2020, while toning down tension over regional crises and domestic authoritarianism (Cumming-Bruce 2019). However, the government's aim in advancing its economic and financial plans is not matched by any equally ambitious plan for reforming the religious establishment's role or defining a path towards civil rights, freedom of expression, and pluralism. Recent reforms such as lifting the ban on women driving and significantly curtailing the powers of the notorious religious police, the mutawa, were hailed as clear signs of the country's turn towards much-debated moderation and tolerance (AP 2016). In addition, a series of high-profile sporting and entertainment events were organised by the General Authority for Entertainment, aimed at boosting the tourism industry and the crown prince's support base, by attracting thousands of young Saudis. Heavyweight and wrestling competitions, formula E, golfing, and high-profile horse races (Snyder 2019) and multiple-days festivals of pop and electronic music (Nereim 2018) received wide international coverage, despite reports that foreign 'social media "influencers"' were allegedly paid by the kingdom to attend and upload content hailing a "social revolution", while lacking any mention of the Saudi human rights record (Gorman 2019). Although they constitute laudable progress in lingering social issues, these reforms and events point towards a modernization by Gulf standards, thus bringing Saudi Arabia closer to the norms followed in the UAE and Qatar, their own reciprocal human rights records notwithstanding.

To the contrary, as Courtney Freer notes, the crackdown since MBS's taking over "signals once again that political space within Saudi Arabia is likely to continue tightening for the foreseeable future" and that the crown prince has "no intention of changing course" (2019). According to human rights organizations, the crackdown on activists and human and women's rights advocates has intensified (Amnesty International 2017), whilst 179 executions were reported by the authorities during 2019 (Human Rights Watch 2020). The number of Saudi nationals seeking political asylum abroad has increased, while the regime is yet to provide full accountability for the Jamal Khashoggi murder in 2018 (Freer 2019). Attacks on freedom of expression and freedom of the press have drawn intense criticism towards the regime, including the allegation that MBS recently sought to threaten Jeff Bezos, owner of the Washington Post (Kirchgaessner and Nikhita 2020).

Activists, intellectuals and clerics are only some segments of Saudi society that have faced MBS's authoritarian style. In addition, important businessmen and high-profile members of the royal family were also detained in the highly symbolic November 2017 "anti-corruption campaign. They have faced charges of corruption, abuse of power, and money laundering (Doucet 2017), in what is seen as a continuous power grab ahead of the succession, where senior royals concerned with MBS's leadership could raise legitimate rights to the throne (Mabon 2018). Adding to this is the fact that the post of deputy crown prince has not been filled since MBS was promoted. Although any such opposition is unlikely to materialize while King Salman is still alive, observers have underlined the position of 77-year-old Prince Ahmed bin Abdulaziz, King Salman's only surviving full brother and one of the three people in the Allegiance Council who voted against MBS becoming crown prince. Having kept a generally low profile, Prince Ahmed has recently appeared more critical towards the leadership and, according to Reuters sources, has responded to the question of whether he will challenge MBS by saying that "we will cross that bridge when we come to it" (Reuters 2019). 


\section{Conclusions}

This paper demonstrated recent shifts in the foreign policy behavior of Saudi Arabia under the pressures brought to the Middle East geopolitical background by the 2011 Arab uprisings and in light of the country's special use of Islam as a foreign policy tool. As it was argued, the current context is mainly driven by a continued balance of power game between Iran and Saudi Arabia and is aggravated by additional factors such as sectarian divisions and intra-Sunni competitions, as well as the US role in various fronts.

Under the leadership of King Salman and Crown Prince Mohammad Bin Salman, Saudi foreign policy behavior is marked by an abrupt change from cautiousness and reserve towards brinkmanship and a destabilizing effect in the region. While regime security and survival remain the absolute priorities, the "Salman Doctrine" brought a "hard power" character to foreign policy decision-making and foreign policy implementation, as it aimed at swiftly gaining a hegemonic regional role, while containing the threats of Iranian expansionism and the influence of the Muslim Brotherhood both at home and in the wider Gulf.

However, as these foreign policy choices produced considerably negative results for the international image of Saudi Arabia, it was also shown that such excessive belligerence is now contained in favor of a more "moderate" approach, towards diplomacy and multilateralism, though without signaling a return to a foreign policy attitude that resembles the characteristics of defensive realism. In addition, the crown prince has put forward a discourse promoting a return to a "moderate Islam". As contradictory as it sounds for a country that has hardly ever demonstrated moderation in its religious practices at home and abroad, it was shown that the notion of "moderate Islam" is deployed anew as a foreign policy tool to serve a double purpose: On the one hand, it aims to promote an image of openness and tolerance that will strengthen its international image and restore its position as Custodian of the Muslim faith, whilst attracting foreign investment in the kingdom. On the other hand, it will also whitewash recent signs of authoritarianism, while justifying the recent rapprochement with Israel in a common front against Iran, thus strengthening the Saudi role in the Gulf region and beyond.

Finally, this paper reflected on the "moderate Islam" discourse as a foreign policy tool and its relation with domestic developments, namely the 'Vision 2030' program and the potential direction of the kingdom with regards to the sort of Islam to which it aims to adhere. While it is too early to predict whether Saudi Arabia will move towards a Salafi nationalism, the current external discourse on moderation seems in stark contrast with the authoritarian rule that MBS has demonstrated internally. Largely viewed as an attempt to silence any opposition and sideline any potential challenge to his way to the throne, the crackdown on religious, business, and royal figures, human rights activists, and journalists could potentially have a boomerang effect on the international level. Recent social reforms aimed at improving the kingdom's image are viewed as a mere public relations campaign, while opposition to the crown prince's path to the throne may occur from marginalized and discontented members of the royal family or the religious and business elite.

Funding: This research received no external funding.

Conflicts of Interest: The author declares no conflict of interest.

\section{References}

AFP. 2019. Qatar Emir to Skip Riyadh Summit Dampening Thaw Hopes. France24, December 10. Available online: https://www.france24.com/en/20191210-qatar-emir-to-skip-riyadh-summit-dampening-thaw-hopes (accessed on 21 December 2019).

Al-Issa, Mohammad. 2019. Why Muslims from around the world should remember the Holocaust. Washington Post, January 25. Available online: https://www.washingtonpost.com/opinions/2019/01/25/why-muslimsaround-world-should-remember-holocaust/ (accessed on 10 March 2020). 
Al-Jazeera. 2018. More than 1000 Saudi Troops Killed in Yemen Since War Began. May 28. Available online: https://www.aljazeera.com/news/2018/05/1-000-saudi-troops-killed-yemen-war-began180528174808387.html?xif= (accessed on 26 November 2019).

Al-Rasheed, Madawi. 2017. Can the Saudi Crown Prince Transform the Kingdom? New York Times, November 10. Available online: https://www.nytimes.com/2017/11/10/opinion/mohammed-bin-salman-saudi-arabia.html (accessed on 20 January 2020).

Al-Sharq Al-Awsat. 2018. MWL, Vatican Bolster Interfaith Dialogue. April 22. Available online: https://aawsat.com/ english/home/article/1245496/mwl-vatican-bolster-interfaith-dialogue (accessed on 10 March 2020).

Amnesty International. 2017. Arabie Saoudite. Une Vague d'arrestations Cible les Derniers Vestiges de la Liberté d'expression. September 15. Available online: https://www.amnesty.org/fr/latest/news/2017/09/saudi-arabiawave-of-arrests-targets-last-vestiges-of-freedom-of-expression/ (accessed on 24 January 2020).

Amnesty International. 2019. Saudi Arabia: Prominent Reformist Cleric Faces Death Sentence for His Peaceful Activism. July 26. Available online: https:/www.amnesty.org/en/latest/news/2019/07/saudi-arabiaprominent-reformist-cleric-faces-death-sentence-for-his-peaceful-activism/ (accessed on 24 January 2020).

AP. 2016. Saudi Arabia Says Religious Police Must Be 'Gentle and Humane'. The Guardian. April 13. Available online: https://www.theguardian.com/world/2016/apr/13/saudi-arabia-says-religious-police-must-be-gentleand-humane (accessed on 22 December 2019).

Arab News. 2019. Muslim World League, Patriarchate of Moscow Sign Cooperation Deal. July 25. Available online: https://www.arabnews.com/node/1530471/saudi-arabia (accessed on 10 March 2020).

Batrawi, Aya. 2017. AP ANALYSIS: Saudi Promise of 'Moderate Islam' Shifts Power. AP News, October 28. Available online: https://apnews.com/577766b7e7494f55850f2e1c40366531/AP-ANALYSIS:-Saudi-promiseof-'moderate-Islam'-shifts-power (accessed on 28 December 2019).

BBC News. 2015. Saudis Announce Islamic Anti-Terrorism Coalition. December 15. Available online: https: //www.bbc.com/news/world-middle-east-35099318 (accessed on 20 November 2019).

Benjamin, Daniel. 2018. Not His Father's Saudi Arabia: The Khashoggi Affair Reveals the Recklessness of MBS. Foreign Affairs. October 18. Available online: https://www.foreignaffairs.com/articles/saudi-arabia/ 2018-10-18/recklessness-of-mohammed-bin-salmans-saudi-arabia?cid=int-fls\&pgtype=hpg (accessed on 27 December 2019).

Blin, Louis. 2016. L'émancipation contrainte de la politique étrangère saoudienne. Politique étrangère. Available online: https://doi.org/10.3917/pe.162.0049 (accessed on 20 December 2019).

Bonnefoy, Laurent. 2018. Le salafisme quiétiste face aux recompositions politiques et religieuses dans le monde arabe (2011-2016). Archives de Sciences Sociales des Religions. January. Available online: https: //doi.org/10.4000/assr.38550 (accessed on 20 December 2019).

Cafiero, Giorgio. 2017. 'Fake news' sparks real crisis in the Gulf. Al-Monitor, May 25. Available online: https://www. al-monitor.com/pulse/originals/2017/05/fake-news-qatar-gulf-gcc-hack-trump-iran-israel.html (accessed on 21 October 2019).

Chulov, Martin. 2017. I will return Saudi Arabia to moderate Islam, says crown prince. The Guardian, October 24. Available online: https:/www.theguardian.com/world/2017/oct/24/i-will-return-saudi-arabia-moderateislam-crown-prince (accessed on 28 December 2019).

Commins, David. 2015. From Wahhabi to Salafi. In Saudi Arabia in Transition. Edited by Thomas Hegghammer and Stephane Lacroix Bernard Haykel. Cambridge: Cambridge University Press.

Cumming-Bruce, Nick. 2019. War Crimes Committed by Both Sides in Yemen, UN Panel Says. New York Times, September 3. Available online: https://www.nytimes.com/2019/09/03/world/middleeast/war-crimes-yemen. html (accessed on 26 November 2019).

Daher, Aurelie. 2018. Liban: Entre clientélisme régional et carcan national. Politique Etrangere. Available online: https://www.cairn.info/article.php?ID_ARTICLE=PE_181_0169 (accessed on 23 November 2019).

Dazi-Héni, Fatiha. 2018a. La monarchie saoudienne et l'affaire Khashoggi. Esprit 12: 13-16. Available online: https://www-cairn-info.lama.univ-amu.fr/revue-esprit-2018-12-page-13.htm\#re7no7 (accessed on 23 November 2019).

Dazi-Héni, Fatiha. 2018b. Arabie Saoudite Bilan Géostratégique. Moyen-Orient Juillet-Septembre: 28-29.

Devji, Faisal. 2018. Will Saudi Arabia Cease to Be the Center of Islam? New York Times, September 7. Available online: https://www.nytimes.com/2018/09/07/opinion/saudi-arabia-islam-mbs.html?login=smartlock\&auth= login-smartlock (accessed on 20 February 2020). 
Doucet, Lyse. 2017. Inside Saudi Arabia's gilded prison. BBC News, November 23. Available online: https://www.bbc.com/news/av/world-middle-east-42098201/inside-saudi-arabia-s-gilded-prisonat-riyadh-ritz-carlton (accessed on 26 November 2019).

Farouk, Yasmine. 2018. The Penalties of a Death. Carnegie Middle East Center, September 17. Available online: https://carnegie-mec.org/diwan/77263 (accessed on 20 January 2020).

Farouk, Yasmine. 2020. What Does the U.S. Killing of Soleimani Mean for Saudi Arabia? Carnegie Endowment for International Peace, January 7. Available online: https://carnegieendowment.org/2020/01/07/what-does-u.s. -killing-of-soleimani-mean-for-saudi-arabia-pub-80722 (accessed on 20 January 2020).

Freer, Courtney. 2019. MBS, Al Awda and the Qatar Blockade. Albawaba, November 30. Available online: https: //www.albawaba.com/opinion/mbs-al-awda-and-qatar-blockade-1324280 (accessed on 15 January 2020).

Gause, F. Gregory, III. 2014. Beyond Sectarianism: The New Middle East Cold War. Brookings Doha Center, July. Available online: https://www.brookings.edu/wp-content/uploads/2016/06/English-PDF-1.pdf (accessed on 3 January 2020).

Gause, F. Gregory, III. 2018. Saudi Regime Stability and Challenges. In Salman's Legacy: The Dilemmas of a New Era in Saudi Arabia. Edited by Madawi Al-Rasheed. New York: Oxford University Press, pp. 31-43.

Gerges, Fawaz A. 2016. ISIS: A History. Princeton and Oxford: Princeton University Press.

Gordon, Philip H. 2018. Saudi Arabia's War in Yemen has Failed. Council on Foreign Relations, November 12. Available online: https://www.cfr.org/article/saudi-arabias-war-yemen-has-failed (accessed on 26 November 2019).

Gorman, Alyx. 2019. 'Shameless' influencers face backlash for promoting Saudi Arabia music festival. The Guardian, December 23. Available online: https://www.theguardian.com/world/2019/dec/23/shameless-influencersface-backlash-for-promoting-saudi-arabia-music-festival (accessed on 22 December 2019).

Hellyer, H. A. 2018a. Don't call the Saudi crown prince a religious reformer-yet. The Globe and Mail, April 10. Available online: https://www.theglobeandmail.com/opinion/article-dont-call-the-saudi-crown-prince-areligious-reformer/ (accessed on 30 January 2020).

Henderson, Simon. 2019. Qatar Rift Overshadows Riyadh Summit. The Washington Institute for Near East Policy, December 9. Available online: https://www.washingtoninstitute.org/policy-analysis/view/qatar-riftovershadows-riyadh-summit (accessed on 19 December 2019).

Hoffman, Jonathan. 2019. Religion, the State and Politics in Saudi Arabia. Middle East Policy, October. Available online: https://mepc.org/journal/religion-state-and-politics-saudi-arabia (accessed on 4 December 2019).

Human Rights Watch. 2020. World Report 2020: Saudi Arabia. Available online: https://www.hrw.org/worldreport/2020/country-chapters/saudi-arabia (accessed on 24 January 2020).

International Crisis Group. 2019. Addressing the Rise of Libya's Madkhali-Salafis. April 25. Available online: https://www.crisisgroup.org/middle-east-north-africa/north-africa/libya/addressing-rise-libyasmadkhali-salafis (accessed on 4 November 2019).

Kirchgaessner, Stephanie, and Chulani Nikhita. 2020. Jeff Bezos, the Saudi Crown Prince and the Alleged Phone-Hacking Plot. The Guardian. January 22. Available online: https:/www.theguardian.com/technology/ video/2020/jan/22/jeff-bezos-phone-hacked-allegation-saudi-crown-prince-video-explainer (accessed on 30 January 2020).

Kirkpatrick, David. 2015. Saudi Arabia Leads Air Assault in Yemen. New York Times. March 25. Available online: https://www.nytimes.com/2015/03/26/world/middleeast/al-anad-air-base-houthis-yemen.html (accessed on 20 November 2019).

Korany, Bahgat, and Fattah Moataz. 2008. Irreconcilable Role-Partners? Saudi Foreign Policy between the Ulama and the US. In The Foreign Policies of Arab States. Edited by Bahgat Korany and Dessouki Ali E. Hillal. Cairo: The American University in Cairo Press, pp. 343-391.

Lacroix, Stephane. 2014. Saudi Islamists and the Arab Spring. LSE Kuwait Programme, May. Available online: https://eprints.lse.ac.uk/56725/1/Lacroix_Saudi-Islamists-and-theArab-Spring_2014.pdf (accessed on 4 December 2019).

Mabon, Simon. 2018. It's a Family Affair: Religion, Geopolitics and the Rise of Mohammed Bin Salman. Insight Turkey. pp. 51-66. Available online: www.jstor.org/stable/26390307 (accessed on 1 November 2019).

Mandaville and Hamid. 2018. Islam as Statecraft: How Governments Use Religion in Foreign Policy. Brookings Institution, November. Available online: https://www.brookings.edu/wp-content/uploads/2018/11/FP_ 20181116_islam_as_statecraft.pdf (accessed on 10 March 2020). 
MEMO. 2019. Why Qatar's Emir may not Attend the Riyadh Summit. Middle East Monitor, December 8. Available online: https://www.middleeastmonitor.com/20191208-why-qatars-emir-may-not-attend-theriyadh-summit/ (accessed on 22 December 2019).

Middle East Monitor. 2015. The Salman Principle. MEMO, March 28. Available online: https://www. middleeastmonitor.com/20150328-the-salman-principle/ (accessed on 20 December 2019).

Mouline, Nabil. 2020. Une nouvelle diplomatie religieuse? Politique Etrangere. Available online: https: //doi-org.lama.univ-amu.fr/10.3917/pe.201.0043 (accessed on 15 March 2020).

Murphy, Caryle. 2011. Heavy police presence deters protesters in Saudi Arabia. PRI, March 11. Available online: https://www.pri.org/stories/2011-03-11/heavy-police-presence-deters-protesters-saudi-arabia (accessed on 4 December 2019).

Nakhleh, Emile. 2017. Saudi Arabia and Qatar: A Tribal Feud with Regional and Global Implications. Future Directions, June 13. Available online: http://www.futuredirections.org.au/publication/saudi-arabia-qatartribal-feud-regional-global-implications/ (accessed on 27 November 2019).

Nereim, Vivian. 2018. Party Time in Saudi Arabia Ends a Year of Fear. Bloomberg. December 19. Available online: https://www.bloomberg.com/news/articles/2018-12-19/party-time-in-saudi-arabia-ends-a-year-offear?fbclid=IwAR3qFi-kf2OrQLrS7_CT_7wKUSNFnxJQsA4LEEK9c4-ySNw0BCP0iPYIK1E (accessed on 22 December 2019).

Nonneman, Gerd. 2006. Determinants and Patterns of Saudi Foreign Policy. In Saudi Arabia in the Balance. Edited by Gerd Nonneman and Paul Aarts. London: Hurst \& Co.

Nuruzzaman, Mohammed. 2019. Chasing the Dream: The Salman Doctrine and Saudi Arabia's Bid for Regional Dominance. Insight Turkey 21: 41. [CrossRef]

Ottaway, David. 2018. Will Saudi Arabia's Social Revolution Provoke a Wahhabi Backlash? Wilson Center, May. Available online: https://www.wilsoncenter.org/sites/default/files/media/documents/publication/126_mep_ viewpoint_david_ottaway.pdf (accessed on 25 January 2020).

Partrick, Neil. 2018. Saudi Defense and Security Reform. Carnegie Endowment for International Peace, May 31. Available online: https://carnegieendowment.org/sada/76487 (accessed on 20 December 2019).

POMED. 2018. Panel: Mohammed Bin Salman's Saudi Arabia: A Deep Look. Project on Middle East Democracy (POMED), March 21. Available online: https://pomed.org/event/mbs-a-deeper-look/ (accessed on 24 January 2020).

Raihan, Ismail. 2019. How is MBS's Consolidation of Power Affecting Clerics in the Opposition? Washington Post, June 4. Available online: https://www.washingtonpost.com/politics/2019/06/04/how-is-mohammadsconsolidation-power-affecting-oppositional-saudi-clerics/ (accessed on 24 January 2020).

Ramani, Samuel. 2019. Saudi Arabia and the UAE Reboot their Partnership in Yemen. Carnegie Endowment for International Peace. September 26. Available online: https://carnegieendowment.org/sada/79925 (accessed on 11 March 2020).

Reuters. 2017. Descendants of Saudi Wahhabism Founder Distance Themselves from Qatar. May 28. Available online: https://www.reuters.com/article/gulf-qatar/descendants-of-saudi-wahhabism-founder-distancethemselves-from-qatar-idUSL8N1IU0AH (accessed on 26 November 2019).

Reuters. 2019. Exclusive: In Saudi Arabia, Criticism of Crown Prince Grows after Attack. October 2. Available online: https://www.reuters.com/article/us-saudi-crownprince-exclusive/exclusive-in-saudiarabia-criticism-of-crown-prince-grows-after-attack-idUSKBN1WH227 (accessed on 5 January 2020).

Rich, Ben. 2019. From Defense to Offense: Realist Shifts in Saudi Foreign Policy. Middle East Policy Council. Available online: https://mepc.org/journal/defense-offense-realist-shifts-saudi-foreign-policy (accessed on 27 November 2019).

Riedel, Bruce. 2017a. In Yemen, Iran outsmarts Saudi Arabia again. Brookings. December 6. Available online: https:/www.brookings.edu/blog/markaz/2017/12/06/in-yemen-iran-outsmarts-saudi-arabia-again/ (accessed on 26 November 2019).

Riedel, Bruce. 2017b. Saudi King Shows No Signs of Slowing Aggressive Foreign Policy. Al-Monitor, July 9. Available online: https:/www.al-monitor.com/pulse/originals/2017/07/saudi-arabia-king-salman-yemenwar-foreign-policy-qatar-g20.html/ (accessed on 28 December 2019).

Riedel, Bruce. 2019. As the Saudis host international summitry, their Yemen problem isn't going away. Brookings Institution, May 28. Available online: https:/www.brookings.edu/blog/order-from-chaos/2019/05/28/as-thesaudis-host-international-summitry-their-yemen-problem-isnt-going-away/ (accessed on 10 March 2020). 
Saab, Bilal Y. 2018. Mohamed bin Salman Unhinged? Maybe Not. The American Interest, September 6. Available online: https://www.the-american-interest.com/2018/09/06/mohamed-bin-salman-unhinged-maybe-not/ (accessed on 30 October 2019).

Saudi Press Agency. 2017. Kingdom of Saudi Arabia severs diplomatic and consular relations with Qatar. In SPA Official Website; June 5. Available online: https://www.spa.gov.sa/viewfullstory.php?lang=en\&newsid= 1637298\# (accessed on 20 October 2019).

Saudi Vision. 2017a. National Character Enrichment Programme. Available online: https://vision2030.gov.sa/en/ programs/NCEP (accessed on 23 November 2019).

Saudi Vision. 2017b. Hajj and Omrah Program. Available online: https://vision2030.gov.sa/en/programs/Hajj-andOmrah (accessed on 23 November 2019).

Al Sayegh, Hadeed. 2017. Saudi king overhauls security services following royal shakeup. Reuters, July 20. Available online: https://www.reuters.com/article/us-saudi-decrees/saudi-king-overhauls-security-servicesfollowing-royal-shakeup-idUSKBN1A52N9?il=0 (accessed on 20 December 2019).

Sayigh, Yezid. 2018. The Warrior Prince. Carnegie Endowment for International Peace, October 28. Available online: https://carnegie-mec.org/diwan/77570 (accessed on 20 December 2019).

Schwedler, Jillian. 2011. Can Islamists Become Moderates? Rethinking the Inclusion-Moderation Hypothesis. World Politics 63: 347-376. [CrossRef]

Sheline, Annelle R. 2019. Declaration Proliferation: The International Politics of Religious Tolerance. Berkley Center, July 11. Available online: https://berkleycenter.georgetown.edu/posts/declaration-proliferation-theinternational-politics-of-religious-tolerance (accessed on 11 March 2020).

SIPRI. 2019. Trends in World Military Expenditure. Stockholm International Peace Research Institute, April. Available online: https://www.sipri.org/sites/default/files/2019-04/fs_1904_milex_2018_0.pdf (accessed on 27 December 2019).

Snyder, Stephen. 2019. Are the Saudis using big sporting events to 'sportwash' their image? PRI, August 21. Available online: https://www.pri.org/stories/2019-08-21/are-saudis-using-big-sporting-events-sportswashtheir-image (accessed on 22 December 2019).

SPA. 2020. Saudi Press Round-up: No more Regional Loyalty to Iran's Sectarian Regime. Saudi Press Agency, January 3. Available online: https://www.spa.gov.sa/viewfullstory.php?lang=en\&newsid=2018987\#2018987 (accessed on 4 December 2019).

Strobel, Warren P. 2019. Qataris, Saudis Make New Bid to Mend a Long-Festering Feud. Wall Street Journal, November 28. Available online: https://www.wsj.com/articles/qataris-saudis-make-new-bid-to-mend-along-festering-feud-11574942401? mod=searchresults\&page=1\&pos=3 (accessed on 3 December 2019).

Takeyh, Ray. 2017. Expert Brief-Saudi Arabia's Shaky Experiment in Modernization. Council on Foreign Relations, November 8. Available online: https://www.cfr.org/expert-brief/saudi-arabias-shaky-experimentmodernization (accessed on 30 October 2019).

The National. 2017. Qatari Sheikh Emerges as Third Main Opposition Figure to Emir's Policies. September 19. Available online: https://www.thenational.ae/world/gcc/qatari-sheikh-emerges-as-third-main-oppositionfigure-to-emir-s-policies-1.629767 (accessed on 26 November 2019).

Tisdall, Simon. 2017. Mohammed bin Salman al-Saud: The hothead who would be king. The Guardian, June 25. Available online: https://www.theguardian.com/world/2017/jun/25/mohammed-bin-salman-saudiheir-young-hothead-with-ambitions (accessed on 28 December 2019).

Tonet, Aureliano, and Marguerita Nasi. 2020. Neom, le rêve hollywoodien de Mohammed Ben Salman pour l'Arabie saoudite. Le Monde, February 10. Available online: https://www.lemonde.fr/international/article/2020/02/ 10/neom-le-reve-hollywoodien-de-mohammed-ben-salman-pour-l-arabie-saoudite_6029009_3210.html (accessed on 11 February 2020).

Ulrichsen, Kristian Coates, and Annelle Sheline. 2019. Mohammed Bin Salman and Religious Authority and Reform in Saudi Arabia. Baker Institute, September 19. Available online: https://www.bakerinstitute.org/ media/files/files/516a1378/bi-report-092319-cme-mbs-saudi.pdf (accessed on 20 January 2020).

Walsh, Declan, and Ben Hubbard. 2019. With U.S. Help No Longer Assured, Saudis Try a New Strategy: Talks. New York Times, December 27. Available online: https://www.nytimes.com/2019/12/26/world/middleeast/ saudi-iran-qatar-talks.html?searchResultPosition=16 (accessed on 4 January 2020). 
White House. 2017. President Trump and King Salman Sign Arms Deal. May 20. Available online: https://www. whitehouse.gov/articles/president-trump-king-salman-sign-arms-deal/ (accessed on 28 January 2020).

Wittes, Tamara Cofman, and Bruce Riedel. 2018. Shuffling the deck chairs in Saudi Arabia. Brooking, December 28. Available online: https:/www.brookings.edu/blog/order-from-chaos/2018/12/28/shuffling-the-deck-chairsin-saudi-arabia/ (accessed on 22 December 2019).

(C) 2020 by the author. Licensee MDPI, Basel, Switzerland. This article is an open access article distributed under the terms and conditions of the Creative Commons Attribution (CC BY) license (http://creativecommons.org/licenses/by/4.0/). 
MDPI

St. Alban-Anlage 66

4052 Basel

Switzerland

Tel. +41616837734

Fax +41 613028918

www.mdpi.com

Religions Editorial Office

E-mail: religions@mdpi.com

www.mdpi.com/journal/religions

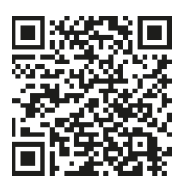



MDPI

St. Alban-Anlage 66

4052 Basel

Switzerland

Tel: +4161 6837734

Fax: +41 613028918

www.mdpi.com 